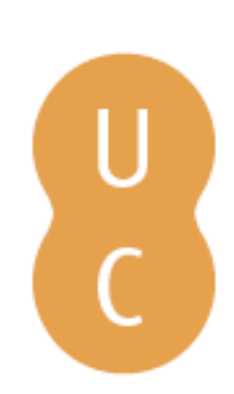

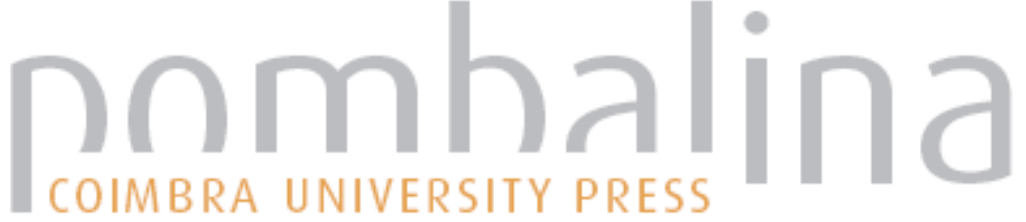

\section{Epigrafia: as pedras que falam}
Autor(es):
d'Encarnação, José
Publicado por: Imprensa da Universidade de Coimbra
URL persistente:
URI:http://hdl.handle.net/10316.2/2701
DOI:
DOI:http://dx.doi.org/10.14195/978-989-26-0186-1

Accessed : $\quad$ 26-Apr-2023 07:22:45

A navegação consulta e descarregamento dos títulos inseridos nas Bibliotecas Digitais UC Digitalis, UC Pombalina e UC Impactum, pressupõem a aceitação plena e sem reservas dos Termos e Condições de Uso destas Bibliotecas Digitais, disponíveis em https://digitalis.uc.pt/pt-pt/termos.

Conforme exposto nos referidos Termos e Condições de Uso, o descarregamento de títulos de acesso restrito requer uma licença válida de autorização devendo o utilizador aceder ao(s) documento(s) a partir de um endereço de IP da instituição detentora da supramencionada licença.

Ao utilizador é apenas permitido o descarregamento para uso pessoal, pelo que o emprego do(s) título(s) descarregado(s) para outro fim, designadamente comercial, carece de autorização do respetivo autor ou editor da obra.

Na medida em que todas as obras da UC Digitalis se encontram protegidas pelo Código do Direito de Autor e Direitos Conexos e demais legislação aplicável, toda a cópia, parcial ou total, deste documento, nos casos em que é legalmente admitida, deverá conter ou fazer-se acompanhar por este aviso.

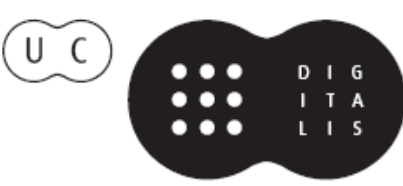


José d'Encarnação

\title{
Epigrafia
}

\section{As Pedras que Falam}

\author{
2. ${ }^{\mathrm{a}}$ edição
}

I

U

- Colmbra 2010 
(Página deixada propositadamente em branco) 

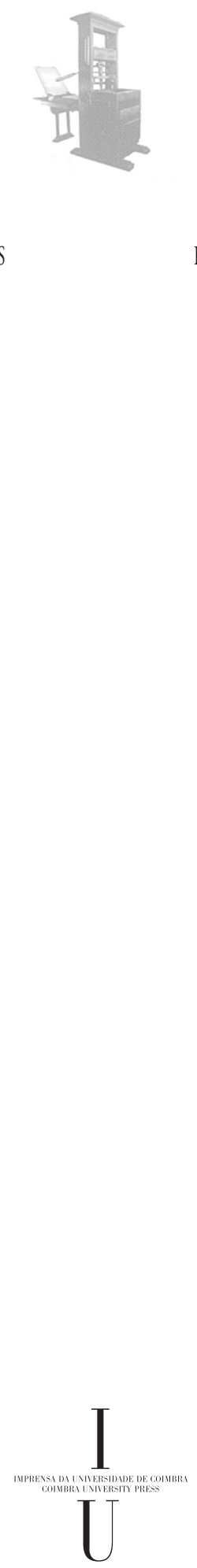
COORDENAÇÃO EDITORIAL

Imprensa da Universidade de Coimbra

CONCEPÇÃO GRÁFICA

Sereer, soluções editoriais

ISBN

978-989-26-0038-3

ISBN Digital

978-989-26-0186-1

DOI

http://dx.doi.org/10.14195/978-989-26-0186-1

DEPÓSITO LEGAL

$306582 / 10$

(C) Março 2010, IMPRENSA DA UNIVERSIDADE DE COIMBRA 
José d'Encarnação

Eprigrafia

\title{
As Pedras que Falam
}

\author{
2. ${ }^{\mathrm{a}}$ edição
}

- colmbra 2010 
(Página deixada propositadamente em branco) 


\section{ÍNDICE}

\section{I - A CIÊNCIA EPIGRÁFICA}

1. Epigrafia - As pedras que falam ................................................... 17

1.1 Leituras novas de um livro eterno ..................................................... 19

1.2 Muros velhos, eloquentes letras .................................................. 23

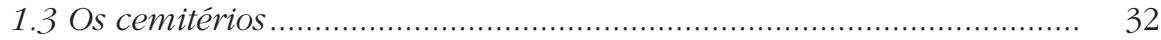

2. Epigrafia em Portugal............................................................... 44

2.1 Ciência antiga, rumos novos .......................................................... 44

2.2 O ensino da Epigrafia ............................................................ 55

2.2.1 O lugar da Epigrafia na Faculdade de Letras......................... 55

2.2.2 Os professores .............................................................. 57

2.2.3 As publicações ................................................................ 57

$$
\text { II - A INSCRIÇÃO }
$$

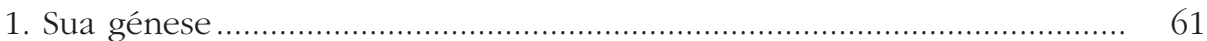

2. O conceito de "oficina epigráfica" ....................................................... 62

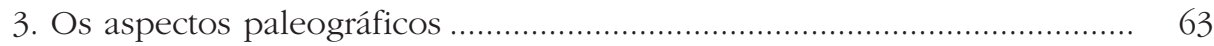

4. Os erros como elemento cultural............................................................. 64

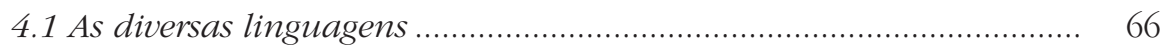


4.2 Exemplos contemporâneos......

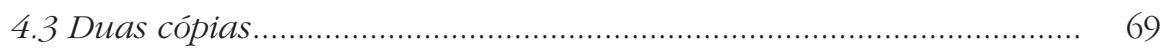

4.4 Ouvir e escrever ................................................................... 71

4.5 A teonimia ......................................................................................... $\quad 72$

5. Alguns termos técnicos ................................................................ 74

\section{III - INTRODUÇÃO AO ESTUDO DA EPIGRAFIA ROMANA}

1. O modo de identificação .............................................................. 79

1.1 A importância do nome ............................................................ 79

1.2 O praenomen ......................................................... 82

1.3 O nomen ........................................................................... 83

1.4 O cognomen ....................................................... 85

1.4.1 Em contexto latino ........................................................... 85

1.4 .2 Em contexto indigena ................................................... 88

1.5 O nome do pai ............................................................... 91

1.5.1 A omissão do patronímico...................................................... 92

1.5.2 Os que não são filhos... do pai ............................................ 93

1.5.3 Duas mães?....................................................................... 94

1.5.4 Os filhos ilegítimos ....................................................... 95

1.5.5 As... linhagens ......................................................... 96

1.6 A tribo, indice seguro da cidadania ......................................... 97

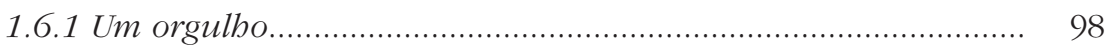

1.6.2 Um índice cronológico...................................................... 99

1.6.3 Uma informação complementar........................................ 100

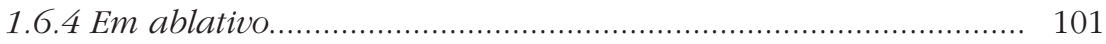

1.6.5 Hereditariedade? ................................................................ 101

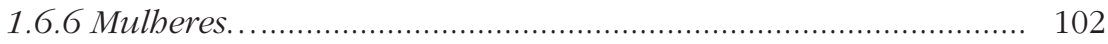

1.6. 7 ... e soldados ................................................................. 104

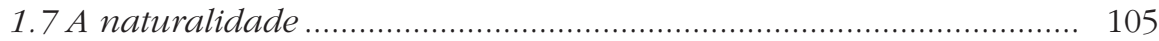

1.7.1 O significado .......................................................... 106 
1.7.2 Origo ou cognomen?

1.7.3 Outras proveniências................................................... 107

2. O cursus bonorum ............................................................. 109

2.1 A carreira senatorial ....................................................................... 109

2.2 A carreira equestre .................................................................. 112

2.3 Outros currículos .......................................................................... 114

3. A identificação dos imperadores .................................................... 115

4. Os monumentos e sua importância documental ................................. 121

4.1 As inscrições funerárias ou a bistoriografia das pessoas ................... 121

4.1.1 Em sintese ....................................................................... 121

4.1.2 O mundo da epigrafia funerária romana .............................. 121

4.1.3 Uma inscrição funerária ................................................... 126

A onomástica ............................................................ 127

A menção da idade................................................................ 128

4.2 A epigrafia religiosa ............................................................. 130

$4.2 .1 \mathrm{Em}$ sintese ................................................................. 130

4.2.2 Um ex-voto.......................................................................... 131

4.2 .3 O sexo dos deuses romanos ........................................... 133

4.2.3.1 "El Sexo Divino", de Sabino Perea .............................. 134

4.2.3.2 Um debate para a aculturação ................................... 138

a) $\mathrm{O}$ "deus» Tutela ................................................ 139

b) "Transformação de ideias".................................. 139

c) Arentius - Arentia ....................................... 140

d) A explicação ...................................................... 141

e) Fontanus / Fontana - um caso de ambiguidade ...... 142

4.2.4 Das religiões e das divindades indígenas na Lusitânia ............ 144

Um culminar ...................................................................... 144

Religião, religiões, divindades......................................... 145

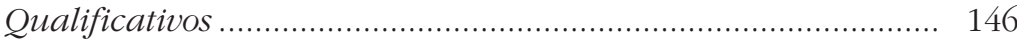

Que divindades?.............................................................. 147

A "escola" bispano-alemã ................................................ 150 
O "retorno à pedra" 151

Um exemplo: Quangeius............................................... 152

As variantes gráficas.......................................................... 156

No dealbar de um novo milénio .............................................. 158

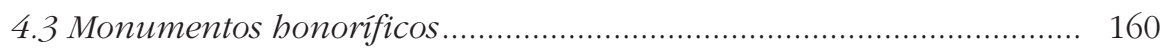

4.3.1 Em sintese .................................................................... 160

4.3.2 Um exemplo................................................................... 160

4.4 Inscrições monumentais.......................................................... 163

4.4.1 Em sintese .......................................................................... 163

4.4.2 Um exemplo.................................................................. 163

O testemunbo de Hübner...................................................... 164

Razão da pintura ........................................................ 166

4.5 Outros documentos epigráficos............................................ 167

4.5.1 Inscrições em mosaicos .......................................................... 167

4.5 .2 Instrumentum ................................................................... 169

4.5 .3 Os miliários ...................................................................... 170

4.5.4 Os termini ......................................................... 172

4.5 .5 Textos jurídicos......................................................... 173

4.5.6 Tabellae defixionum .................................................... 177

4.5.7 As tésseras ............................................................................ 178

\section{IV - A PRÁTICA DO EPIGRAFISTA}

1. Auxiliares de leitura .................................................................... 181

1.1 A fotografia ................................................................... 181

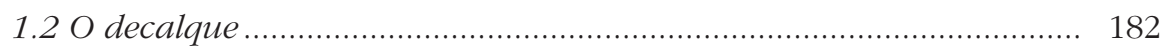

2. O estudo de um monumento epigráfico ......................................... 183

2.1 Dados a incluir.................................................................... 183

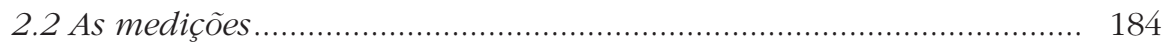

2.3 A descrição................................................................................ 186

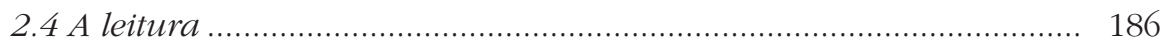


2.5 O comentário

2.6 O estudo de uma inscrição inédita ............................................... 190

2.7 As falsificações e as cópias.......................................................... 193

3. A valorização museográfica das epígrafes............................................... 196

\section{V - ELEMENTOS PARA UM MANUAL}

DE EPIGRAFIA ROMANA PENINSULAR

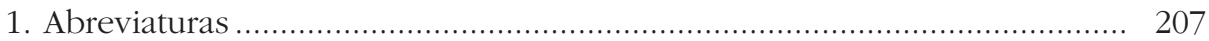

Prenomes................................................................................ 207

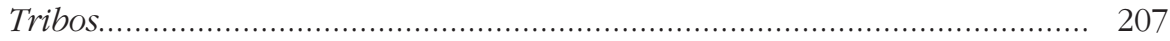

Abreviaturas mais frequentes ............................................................. 208

Os imperadores e os seus títulos ..................................................... 211

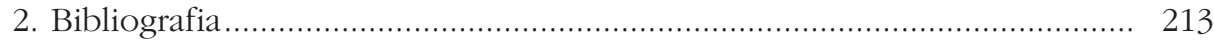

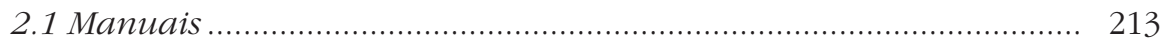

2.2 Corpora peninsulares ........................................................... 214

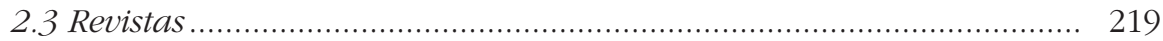

2.4 Catálogos epigráficos dos museus portugueses............................... 220

2.5 Obras sobre antroponímia ...................................................... 222

2.6 Estudos baseados na epigrafia ............................................... 223

2.6.1 Sobre religião................................................................ 223

2.6.2 Sobre estruturas sociais.................................................. 224

2.6.3 Sobre organização politico-administrativa ............................. 225

2.7 Algumas notas à bibliografia ................................................. 226

2.7.1 As grandes colecções .............................................................. 226

2.7.1.1 O CIL II........................................................... 226

2.7.1.2 Outras colecções peninsulares................................ 227

2. 7.1.3 Bibliografias .................................................... 228

2.7.2 A antroponímia............................................................ 229

2.7 .3 A religião .............................................................................. 229

3. Noções elementares de Latim.................................................... 230 
(Página deixada propositadamente em branco) 


\section{APRESENTAÇÃO}

Durante muito tempo, o monumento epigráfico apenas se considerou relevante fonte histórica no âmbito da História Antiga. Compreende-se: as "pedras com letras" eram abundantes; apareciam um pouco por toda a parte; detinham o carácter ímpar de serem originais, chegadas a nós tal como o lapicida as concebera; abrangiam, por fim, todos os domínios históricos: religião, culto dos mortos, onomástica, legislação, monumentos importantes, personagens ilustres, vida económica e o quotidiano, até, por serem cada vez mais numerosos os grafitos nelas descobertos.

Para um período como o da História Romana ou Grega, para que apenas a Arqueologia podia trazer informações concretas e se tinha a consciência clara de que a literatura era "fonte" mas de um valor decerto relativo, erudito, elitista (Quem lia? Quem escrevia? Quem nos garantia a fidelidade das versões chegadas até nós?...) - a Epigrafia representava, assim, manancial insubstituível. Que se saberia dos Lusitanos ou da organização romana na Península Ibérica sem os documentos epigráficos?

Depois, desde meados do século passado sobretudo, a "pedra com letras" deixou de ser mera pedra com um texto a decifrar. Decifrar era aliciante, sem dúvida; mas, mais do que isso, importava contextualizar: porque se escrevera aquilo ali, naquele tipo de suporte, naquele tipo de monumento, com aquelas palavras e não outras. De "pedras com letras" passámos ao domínio das "pedras que falam”...

A disciplina de Epigrafia Latina foi, pois, desde há muito, considerada essencial num currículo de Arqueologia ou História da Arte, primeiro como semestral, 
depois como anual, considerando-se que os seus ensinamentos tanto podem servir para os tempos romanos como para a actualidade.

Constitui este livrinho o primeiro ensaio nesse sentido. Não muito longo no que à epigrafia em geral diz respeito; mais pormenorizado e actualizado, contudo, no que se refere à epigrafia romana, dadas as suas características próprias.

E se as três primeiras edições - sob o título Introdução ao Estudo da Epigrafia Latina (Coimbra, Instituto de Arqueologia, 1979, 1987 e 1997) - deram exclusivo relevo à Epigrafia do tempo dos Romanos, intercalámos, nesta $4^{\underline{a}}$ edição, os elementos que, entretanto, fomos construindo ao longo dos anos e que, dispersos por aqui e acolá, se tornavam de não muito fácil acesso. Deixa, por isso, de ser apenas o "manual" didáctico, sintético, depurado, para apresentar também, desde já, pistas de reflexão, que complementam, de certo modo, o que então escrevemos e o que foi consignado também nos Estudos sobre Epigrafia (Coimbra, Minerva, 1998). No fundo, uma despretensiosa obra em construção.

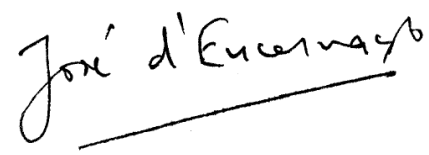


A CIÊNCIA EPIGRÁFICA 
(Página deixada propositadamente em branco) 


\section{EPIGRAFIA - AS PEDRAS QUE FALAM}

Etimologicamente, "epigrafia" é a escrita ("grafia") sobre ("epi») determinado suporte.

E se pusermos de parte uma epigrafia efémera aquela que - à semelhança da "arte efémera" dos nossos dias - apenas servia para um momento e depois se esvanecia, poderemos acrescentar que o suporte adequado para a mensagem epigráfica é o suporte "duradouro»: a pedra, o metal, a cerâmica, o vidro...

Parte-se do princípio que estamos perante uma mensagem sintética, pensada e que visa - se possível - alcançar a eternidade: não se escreve nos epitáfios do cemitério «eterna saudade»?...

Aprecio, no entanto, de modo muito particular, a definição que Giancarlo Susini nos legou e que assim traduzi: «O estudo da forma como, em determinado momento, o Homem seleccionou ideias para deixar de si uma imagem para os vindouros".

Creio que reside aqui tudo, no que concerne à definição mas também no que respeita aos métodos e aos objectivos desta ciência só aparentemente "auxiliar" da História, se atribuirmos ao adjectivo "auxiliar" um lugar, digamos, "secundário", "menor"... E o presente volume demonstrará, estou certo, que, sem o recurso aos documentos epigráficos, a reconstituição de uma época pode seriamente ficar incompleta.

O método será decifrar o texto; mas o objectivo irá mais longe do que isso, pois visará uma integração histórica o mais cabal possível desse monumento, entendido como "documento cultural", fruto acabado de uma conjuntura precisa. 
Ao epigrafista competirá, pois, fazer esse enquadramento histórico. Daí que Raymond Bloch o diga de uma forma assaz lapidar: se o historiador deve ser epigrafista, não há verdadeiro epigrafista que não seja historiador. Di-lo Raymond Bloch em relação à Antiguidade Clássica ${ }^{1}$; mas é asserção passível de aplicar-se a todas as épocas, sem excepção.

$\mathrm{Na}$ 'apresentação', já se deu conta das bases em que se alicerça a importância dos documentos epigráficos como fonte histórica, servindo-nos de uma argumentação bem explanada por Wuilleumier ${ }^{2}$ : os monumentos epigráficos são abundantes, originais, encontram-se por toda a parte (e não apenas em arquivos ou bibliotecas antigas...) e há-os sobre todos os domínios da actividade humana.

Nem sempre assim se encararam os estudos epigráficos. Claro que, a princípio, apenas o texto - devido, inclusive, ao seu carácter hermético, pleno de siglas e de abreviaturas, a suscitar a curiosidade própria de quem deseja descobrir um enigma... - mereceu atenção. Sentiu-se, porém, desde o início que a existência de uma inscrição lapidar era - podia ser - garante de autenticidade de uma afirmação ou de um determinado acontecimento histórico. Por isso, André de Resende, para demonstrar a importância da "Sua" Évora em tempos de Sertório, não hesitou em mandar esculpir epígrafes importantes, que largamente comentou nas suas Antiguidades da Lusitânia.

Pouco a pouco, porém, se verificou que o tipo de monumento, o tipo de material, a ornamentação, o próprio tipo de letra usado, a paginação (passível de nos auxiliar a reconstituir o contexto original para que fora pensada a epígrafe)... eram inúmeros aspectos, enfim, que necessitavam de análise, susceptíveis de curiosas conclusões.

\footnotetext{
${ }^{1}$ R. BLOCH, L'Épigraphie Latine, PUF, Paris, ${ }^{3} 1964$, p. 6: “On conçoit mal un historien de Rome qui ne soit pas en une certaine mesure épigraphiste, mais à coup sûr, il n'est pas d'épigraphiste qui ne soit, en même temps, historien".

${ }^{2}$ P. WUILLEUMIER, "La contribution de l'épigraphie latine à la connaissance de la civilisation romaine", Aufstieg und Niedergang der Römischen Welt, Berlim/Nova Iorque, II I, 1974, p. 790-795.
} 


\subsection{Leituras novas de um livro eterno}

Uma escrita 'lapidar', feita de códigos que importa decifrar. Por isso foi importante a Pedra de Roseta, para compreensão dos hieróglifos; por isso, na Expo'98, ocupava lugar de relevo, no pavilhão da Guatemala, a estela de um guerreiro maia, achada em 1996 e datada de 90 d. C. (!), redigida numa escrita já decifrada a que se deu o nome de "glifos"; por isso, ainda nos seduzem as tabuinhas "rongo-rongo" da indecifrada escrita da misteriosa Ilha de Páscoa; por isso, mais perto de nós, no Sudoeste alentejano, continuam a merecer atenções as estelas redigidas na ainda enigmática "escrita do Sudoeste», datável da Idade do Ferro...

Desde sempre o Homem optou por consignar na "pedra" aquilo que desejava perdurasse para sempre. O próprio Deus, rezam as Escrituras, foi na pedra que gravou as suas leis:

"Depois de o Senhor ter acabado de falar a Moisés no monte Sinai, entregoulhe as duas tábuas do testemunho, tábuas de pedra, escritas com o dedo de Deus" (Exodo, 31, 18).

E o profeta Job proclamava:

"Oh! Quem me dera que se escrevessem as minhas palavras e se consignassem num livro, gravadas por estilete de ferro numa lâmina de chumbo, ou se esculpissem em pedra, para sempre!» (Job 19, 23-24).
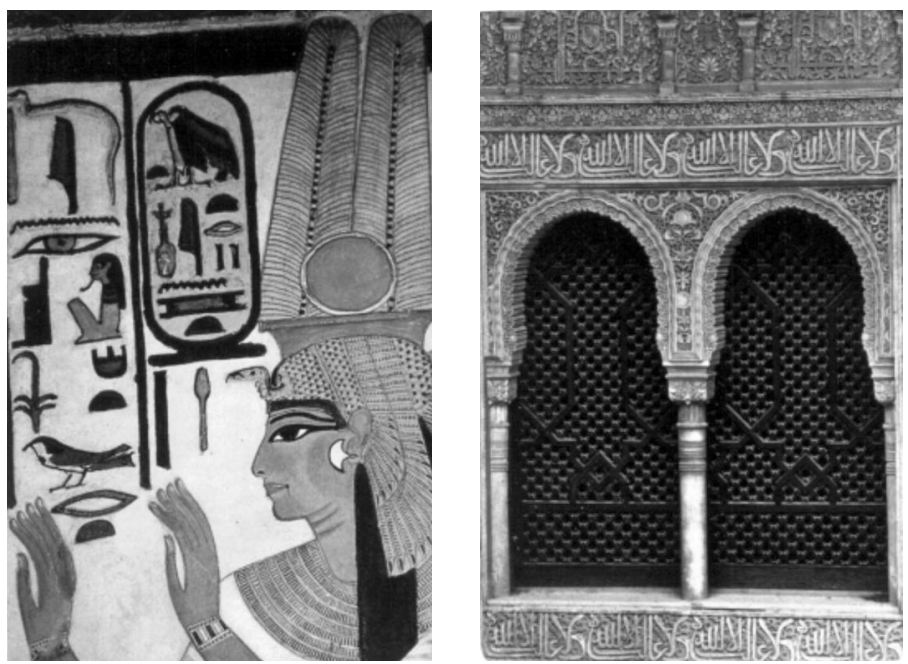
Não se imagina a civilização egípcia sem hieróglifos a decorarem templos, palácios e túmulos. Não nos passeamos por uma antiga cidade romana sem que, nos edifícios, nas ruas, em singelo fragmento cerâmico, topemos solenes dedicatórias, propaganda eleitoral, singela marca de oleiro... ${ }^{3}$ E até em palácios árabes - recordo o Alhambra de Granada - a escrita cúfica mostra passagens do Alcorão, saúda Alá e embeleza fachadas...

Em catedrais mediévicas, em capelas de devoção, frias lápides memoram quem ali jaz...

Nomes de ruas: o actual, o antigo (por baixo), numa língua só ou obrigato-

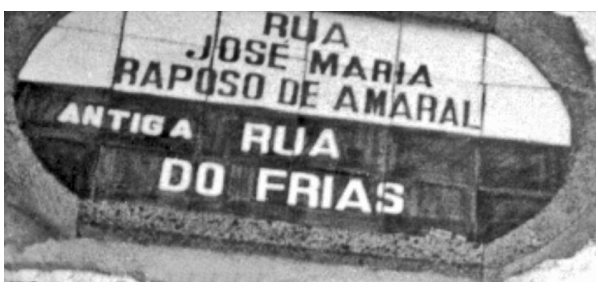
riamente em dois idiomas (e qual deles é o primeiro?) quando as autonomias a tal obrigam... A toponímia urbana, eloquente reflexo das políticas ao longo dos tempos...

Achou-se em Idanha-a-Velha, sede da romana civitas Igaeditanorum, impo-

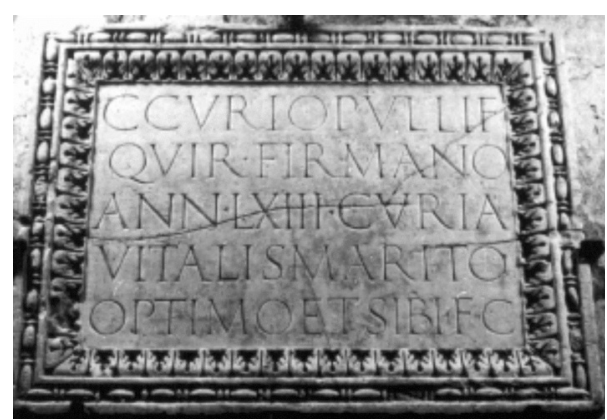
nente placa, de mármore (em terra de granito...), profusamente decorada.

Destinava-se à fachada de um (decerto) não menos imponente jazigo de família. Reza, em latim, que Cúria Vital o mandara erigir para si e para o "óptimo marido", Gaio Cúrio Firmano, falecido aos 63 anos. Contudo, a mulher optou por identificação mais completa do defunto: acrescentou-lhe a filiação ("filho de Pulo") e a tribo a que fora adscrito, a Quirina. Dois pormenores que, à primeira vista, poderão parecer de somenos, mas o não são:

\footnotetext{
3 Pôs Marguerite Yourcenar na boca do imperador Adriano as seguintes palavras: "Coisa alguma iguala a beleza de uma inscrição latina, votiva ou funerária: essas poucas palavras gravadas na pedra resumem com uma majestade impessoal tudo o que o mundo precisa de saber de nós" (in $A$ Vida Apaixonante de Adriano, Editora Ulisseia, s/ d., p. 35-36).
} 
- mencionando o pai, portador de um nome de significado concreto ("pullus" quer dizer "frango") e de conotação indígena, acentua o seu orgulho em pertencer ao estrato populacional pré-romano, origem que não enjeita;

- escrevendo a tribo, assinala que seu marido foi, por méritos próprios, elevado à categoria de cidadão romano, inscrito, por tal motivo e de pleno direito, no rol dos cidadãos igeditanos. E esse orgulho é tanto mais de realçar quanto - por terem o mesmo nome de família - marido e mulher ganharam foros de cidadania por influência da importante família dos Curii, gente sem dúvida bem relacionada com o poder central...

Eloquentes são também, como se sabe, dos mais variados pontos de vista, as chamadas "tábuas de milagres", onde as inscrições ocupam lugar preponderante, em santuários devotos dos séculos XVIII e XIX.

E, numa esquina das velhas ruelas de Roma, fácil será depararmo-nos com singela e quase escondida lápide que diga o seguinte:

«Por ordem de monsenhor, ilustríssimo e reverendíssimo presidente das ruas, proíbe-se a todas e a cada uma das pessoas de fazerem imundícies neste sítio, sob as penas expressas no édito emanado no dia 6 de Agosto de 1748 ".

Ou estoutra:

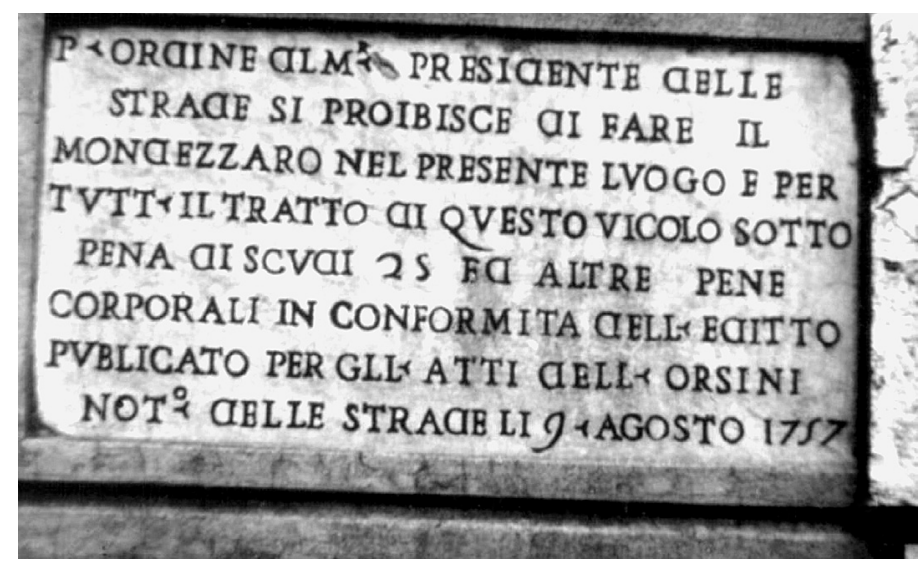


"Por ordem do monsenhor presidente das ruas, proíbe-se fazer imundícies no presente lugar e por todo o trajecto deste beco, sob pena de 25 escudos e outras penas corporais, em conformidade com o édito publicado pelos autos de Orsini, notário das ruas, a 9 de Agosto de 1757".

Meados do século XVIII, preocupações com a higiene pública um pouco por toda a Europa. Recordem-se, entre nós, as consequências do terramoto de 1755 , os poderes excepcionais atribuídos, a partir de 1780, ao Intendente-geral da Polícia e da Corte, Diogo de Pina Manique, para «limpar» Lisboa...

Quem pensaria que, também neste aspecto, a Epigrafia poderia ter uma palavra a dizer?

E quando, no cemitério da Guarda, sob o retrato que encima uma campa, se pode ler:

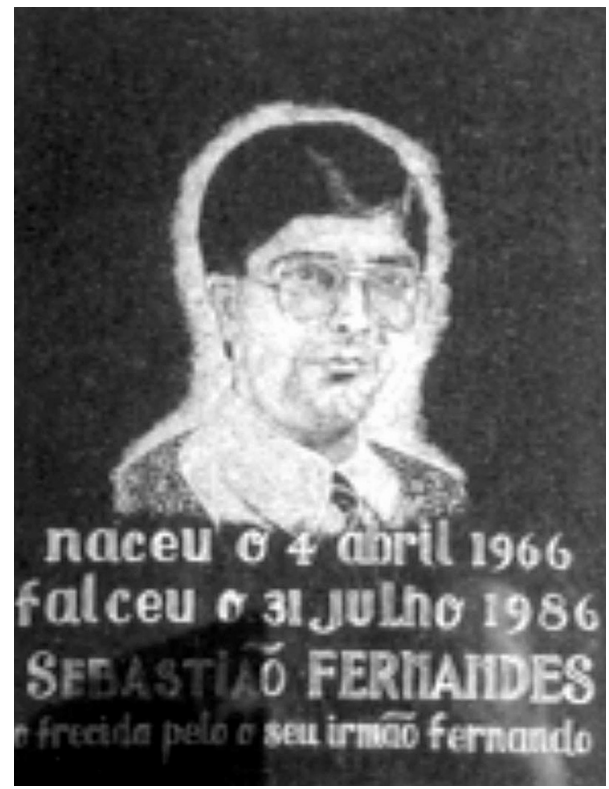

naceu o 4 abril 1966

falceu o 31 Julho 1986

SEBASTIAÕ FERNANDES

Ofrecida pelo o seu irmaõ fernando

- que mundo imenso de reflexões imediatamente nos ocorre?...

Essa, a Epigrafia que professamos, em constantes leituras novas de um livro eterno, fruto amadurecido de um determinado ambiente - político, económico, social e... cultural! 


\subsection{Muros velbos, eloquentes letras...}

$\mathrm{Na}$ verdade, basta estarmos atentos à nossa volta para nos apercebermos de como as epígrafes preenchem o nosso quotidiano.

É sabido como, desde sempre, o Homem utilizou para as suas edificações os materiais pétreos que tinha mais à mão. Por isso, logo nas muralhas do século III e seguintes se reaproveitaram os monumentos epigráficos que ornavam praças e necrópoles, pois já lhes perdera o sentido, já desaparecera por completo a família do homenageado ou, até, já se desconhecia o significado real daquelas siglas e letras.

Mérida guarda na sua alcáçova quase uma centena (identificada) de monumentos funerários de Augusta Emerita; nos castelos de Leiria e de Porto de Mós estão encastradas inscrições romanas em reaproveitamento; nas paredes de Bracara Augusta puseram-se, no século XVIII, monumentos romanos epigrafados encontrados no local ${ }^{4}$; várias das epígrafes conhecidas de Conimbriga provieram das muralhas do século IV, o mesmo acontecendo em Aeminium, Ossonoba, Ebora e Pax Iulia...

Mas o arqueólogo de primórdios do III milénio não atentará apenas nestes vestígios da época romana: da Idade Média, do Renascimento, das épocas posteriores e mesmo da actualidade, há por essas paredes - ocultas e à mostra - inscrições, frases, dizeres, que constituem eloquente testemunho de um passado a não enjeitar.

Recordaria, por exemplo, as placas azulejadas mandadas afixar, há décadas, pelo Automóvel Clube de Portugal por todo o País, que são os sinais claros, no terreno, de um tecido urbano cuja memória, por vezes, corre, neste momento de avassaladora euforia urbanizadora, sério risco de se perder.

E talvez valha a pena demorarmo-nos um pouco - por não estar muito divulgado - sobre o significado profundo desta iniciativa do Automóvel Clube de Portugal, a fim de melhor nos apercebermos da sua real importância na história nossa contemporânea.

\footnotetext{
${ }^{4}$ Um deles de grande interesse documental: cf. José d'ENCARNAÇÃO, "Arqueologia e Epigrafia: uma complementaridade a potenciar", Trabalbos de Antropologia e Etnologia 33 (1-2) 1993 313-327.
} 
Na verdade - e graças ao inestimável apoio da Dra. Luísa Valsassina, actual responsável pelo Centro de Documentação do ACP - pude verificar quão longa foi a luta dos órgãos directivos do Clube junto das entidades competentes, mormente a Junta Autónoma das Estradas, para que se melhorasse, em vista do progresso e, sobretudo, do turismo e do prazer de viajar, a sinalização das estradas portuguesas.

E curioso é verificar que, na pág. 31 do no 46 (Agosto de 1934) de A. C. P. Revista Ilustrada de Automobilismo e Turismo, o órgão oficial do ACP, profusamente se documenta, com fotografias, "a nova sinalização das nossas estradas", enquanto, na p. 29, se reclamava contra o vandalismo:

"Continuam a registar-se selváticos atentados contra os postes de sinalização a que urge pôr cobro".

E os atentados, diz-se no corpo do artigo, não se devem apenas ao «rapazio ignorante e mal educado", "o que nos enche de indignação é que em muitas delas se descortinam sinais de chumbadas, o que revela que muitos caçadores se entretêm a alvejá-las com as suas armas para regular a eficácia do tiro".

E o anónimo articulista comenta:

"Trata-se dum procedimento digno em absoluto dum país de cafres a que é necessário opor as mais severas sanções".

Apetece acrescentar: ontem como hoje!

Interessante outrossim será para a história da epigrafia urbana recortarmos uma passagem do capítulo referente à sinalização, retirada do relatório da Comissão de Turismo do ACP respeitante ao ano de 1933:

"Rara é a terra portuguesa que não ostenta nas suas entradas a placa indicativa do respectivo nome. (...) Pusemos de parte, este ano, as chapas de ferro zincado pintadas a tinta de esmalte (apesar de terem sido estas, até há pouco, as mais usadas em todos os países), pois que a pouca estabilidade dessas tintas devido à acção do tempo, não compensa o seu custo, e adoptámos o 
cimento armado, com as cores impregnadas na espessura de 0,01 m, o que, a não sobrevirem vandalismos, lhes dará uma duração quase ilimitada”.

E houve igualmente o cuidado de se darem instruções precisas quanto à colocação dessas placas: "frente à marcha e a uma altura nunca superior a 2,50 m".

Substituía-se o ACP às entidades oficiais nessa sinalização toponímica. Contudo, na acta da sessão da Comissão de Turismo de 5 de Janeiro de 1937, diz-se expressamente, fazendo o balanço do que fora essa importante actividade em anos anteriores:

"Cessou, porém, esse trabalho, quando, por decreto ministerial, foi vedado o prosseguimento dessa tarefa, que ficou exclusivamente a cargo do organismo oficial Junta Autónoma de Estradas. No entanto, nunca deixou o nosso Club de patrocinar, por intermédio dos seus Delegados, membros também desta Comissão, na referida Junta Autónoma de Estradas e no Conselho Superior de Viação, todos os alvitres interessantes que lhe foram apresentados, conseguindo quase sempre os objectivos em vista".

Não me foi ainda possível determinar quando é que, de novo, vai pertencer ao ACP, agora por intermédio de azulejos cada qual com sua letra, feitos em série na Fábrica da Viúva Lamego (se não erramos), colocar o nome da povoação logo à entrada ou as indicações dos itinerários principais, sendo o conjunto sobre o comprido encimado a meio, discretamente, pelas siglas entrelaçadas do ACP. Aliás, essa fora a primeira ideia, sugerida logo na reunião da Comissão de Turismo a 6 de Janeiro de 1929: interceda-se junto das câmaras municipais e das comissões de iniciativa locais para que se coloquem os letreiros das povoações de maneira que fiquem bem visíveis; poderiam mesmo, em sua opinião, ser pintados no primeiro prédio das povoações; e que se oficiasse ao Conselho de Viação nesse sentido.

Creio, todavia, que a iniciativa das placas azulejadas datará dos finais da década de 40, primórdios da de 50 e compreender-se-á, por isso, o seu inigualável valor, se atendermos, inclusive, a que foi a partir dos anos 50 do século passado que se começou a registar um significativo alargamento das áreas urbanas. 
Por conseguinte, à pergunta "retirar, ou não, do actual contexto" as placas do ACP, a resposta terá de ser forçosamente negativa: NÃO!

E os executivos camarários (ou, se se quiser, a própria Associação Nacional dos Municípios Portugueses) deveriam, de imediato, lançar uma directiva no sentido de essas placas serem rigorosamente preservadas e - porque não? - até recuperadas as que já foram vítimas de maus tratos, tarefa a que, estou certo, o próprio ACP terá muita honra em se associar.

Nesse caso, não se podem deitar abaixo os prédios antigos? Evidentemente que uma acção não é impeditiva da outra. E dou um exemplo.

A 19 de Outubro de 1992, a Associação Cultural de Cascais atribuiu prémio de restauro de arquitectura popular a uma casa à entrada norte de Manique de Baixo, típica aldeia da freguesia de Alcabideche, concelho de Cascais. Toda a casa fora renovada, mas mantivera-se rigorosamente a traça e a volumetria original de habitação tipicamente saloia. Na parede, lá estava a placa do ACP com o nome da povoação. O proprietário, José Guedes, mandou retirá-la para rebocar a parede e determinou que fosse recolocada no sítio preciso donde se tirara. E a memória documental manteve-se.

Em contrapartida, na principal artéria por onde, do centro da vila de Cascais, se seguia para norte, um prédio antigo ostentava, com a devida seta, o letreiro

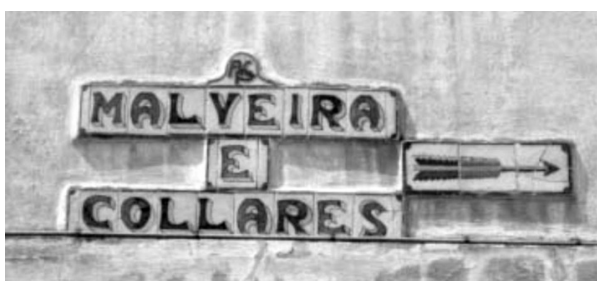

Quando se soube que o prédio ia ser demolido, para dar lugar a um imóvel de arquitectura dita "pós-modernista", chamámos a atenção na imprensa local: feita a obra, os azulejos deveriam ser recolocados.

Não nos ligou importância o Executivo camarário e, muito menos, o sábio empreendedor para quem (decerto) tudo aquilo não passava de 'velharias' que não lhe traziam dividendos económicos. Por acaso, até, se calhar, se enganou redondamente: que a presença dos azulejos antigos despertaria, sem dúvida, a curiosidade dos transeuntes, habitantes ou passantes!... Isso é, porém, mentalização que não se adapta à 'outra' mentalidade economicista de construtores civis... 
E perdeu-se uma importante memória. Primeiro, porque se assinalava um itinerário principal dentro da povoação. Muitos de nós, felizmente, ainda o conhecemos como tal; mas os nossos filhos já disso se não puderam aperceber. Depois, ficava-se a saber quais eram, na altura, os destinos mais importantes e que poderiam não corresponder aos que hoje o são. No caso vertente, por exemplo, Malveira é, mas Colares, para as gentes de Cascais, não é seguramente, neste dealbar do século XXI, um dos destinos preferidos. E ocorrerá interrogarmo-nos como historiadores: porque o seria Colares então?

Lateralmente - embora não de somenos preço - a análise gráfica: Collares ainda há pouco tempo atrás se grafava com dois LL, e aqui temos uma prova disso.

Em Cascais - terra dita 'civilizada' - procedeu-se como se viu. Estoutra

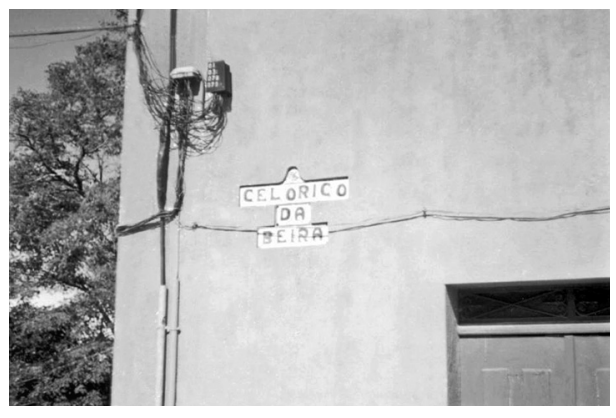
foto, porém, feita por um dos meus estudantes que compreendeu a mensagem, demonstra como em Celorico da Beira, no interior do País, pelo menos neste caso, a mentalidade foi outra: a casa remodelou-se mas o letreiro manteve-se cuidadosamente colocado no sítio.

O apelo, pois, é evidente e urge: associações de defesa do património de todas as terras portuguesas unam-se nesta campanha de miudamente registarem onde se encontravam ou encontram esses letreiros do ACP! Lutem para que sejam restaurados os que estão danificados. Não descansem enquanto as autoridades competentes não obriguem os proprietários a manter essas "relíquias» no sítio original onde foram colocadas!

Impõe-se, além disso, ampla campanha na imprensa local para que fotograficamente se registem esses testemunhos e, a propósito, sobre eles os redactores responsáveis escrevam o resultado da investigação que acerca do contexto original do letreiro forçosamente tiveram que empreender.

Não seria, então, preferível recolher esses letreiros no museu municipal? Deixar réplicas? - essas, as questões que se nos põem em relação aos monu- 
mentos epigráficos mais antigos: pré-romanos, romanos, medievais, da época moderna ou, mesmo, dos séculos XVIII e XIX.

Que fazer da importante inscrição romana dedicada à deusa Ísis encastrada na parede da Sé de Braga (CIL II 2416)?

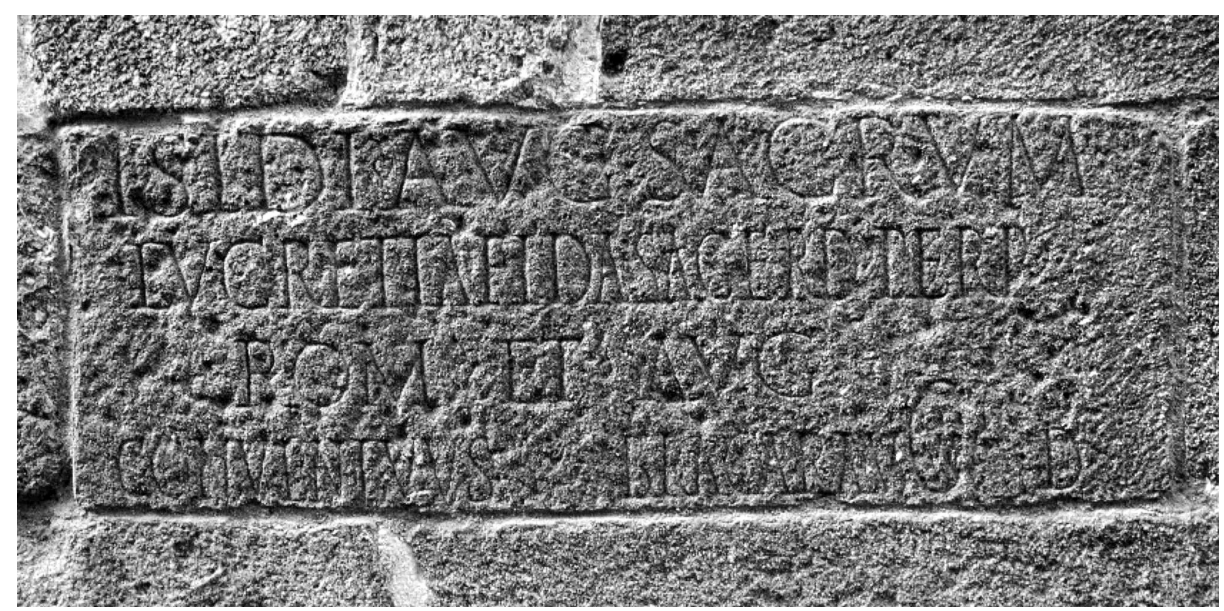

Que atitude propor em relação à notável placa funerária (IRCP 459), em risco de degradação, existente no cunhal da ermida de Nossa Senhora de EntreÁguas (freguesia de Benavila, concelho de Avis)?

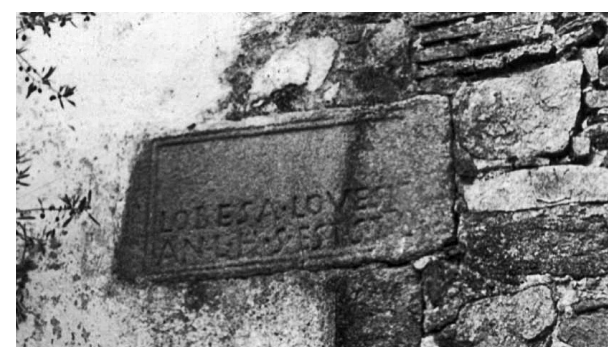

No século XVIII, os nossos académicos preconizavam que se fizessem réplicas e se menosprezasse o original. Lembro o caso, bem conhecido, da famosa inscrição que encima a porta principal da igreja da Bobadela (concelho de Oliveira do Hospital): o original, certamente já truncado quando apareceu, foi copiado como se lia:

\section{SPLENDIDISSIME CIVITATI JV= LIA MODIS TAPLAMINIA}

Junto do texto, começando num lado e continuando no outro, em jeito de didascália, a informação:

ESTE / LETR / SE A=/CHOVNA/JGR ${ }^{a}$ VE/LHA 
E, numa cartela reentrante, a data: 1746 .

Não quer isto dizer - como muito bem frisou Regina Anacleto ${ }^{5}$ - que o "letreiro" haja sido encontrado na igreja velha, ou seja, naquela que fora a anterior matriz e que esta veio substituir. Não. De resto, há informação de que o fragmento de epígrafe - quiçá o original - estava «em hua nave». Decidiram, portanto, os construtores da nova matriz dar-lhe lugar de relevo, pois se lhes afigurava tratar-se de "coisa" importante, a solenemente transmitir aos vindouros. Mesmo que se não apercebessem da retumbância que viria a ter a expressão "splendidissima civitas", nem suspeitassem das relevantes funções cometidas, ao tempo dos Romanos, a uma flamínia, ainda que Modesta (e não "modista") de seu nome...

$\mathrm{Na}$ Rua dos Falcões, em Braga, depara-se-nos, surpreendentemente, embutida na parede de um edifício pertença do hospital, o que parece ser uma placa rectangular sobre o alto, de contornos irregulares, em bastante mau estado de conservação já. Uma análise um pouco mais atenta leva a concluir tratar-se de uma dedicatória a Júpiter Óptimo Máximo feita, ao tempo de Marco Aurélio, por Aemilius

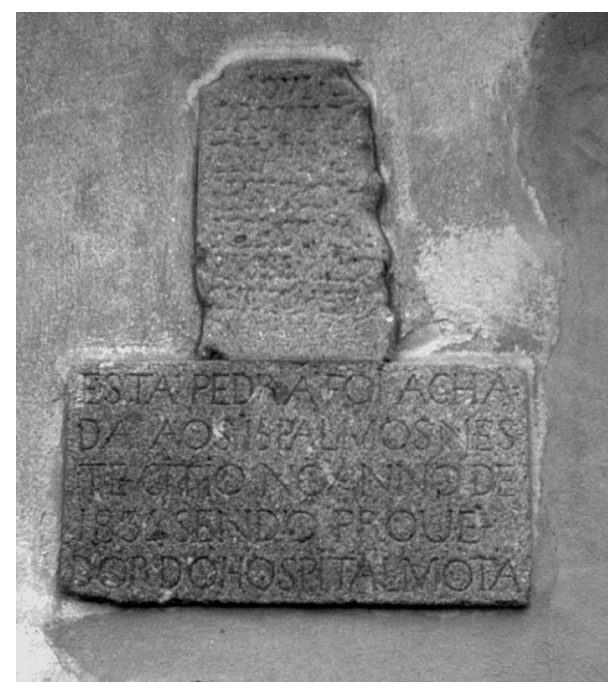
Crescens, nada mais nada menos que o comes - companheiro de armas, ajudante de campo - do senador Triário Materno, legatus iuridicus, ou seja, um representante do imperador nessa região ${ }^{6}$.

Neste momento, não é tanto a inscrição romana que nos interessa - embora ela mereça (creio) um estudo mais aprofundado do que lhe tem sido feito até aqui, mormente porque seria interessante saber qual a tipologia original do

\footnotetext{
5 ANACLETO (Regina), Bobadela Epigráfica, Coimbra, 1981, p. 16

${ }^{6}$ CIL II 2415
} 
monumento (para o que as dimensões da profundidade se me afiguram fundamentais) - é a outra placa que lhe está por baixo e que diz:

ESTA PEDRA FOI ACHA

DA AOS 15 PALMOS NES

TE CITIO NO ANNO DE

I835 SENDO PROUE

DOR DO HOSPITAL MOTA

Dois notáveis documentos históricos:

- primeiro, os achadores da pedra houveram por bem não a danificar e reutilizaram-na, deixando bem visível a face epigrafada, porque se aperceberam do seu interesse histórico;

- depois, não contentes com isso, decidiram imortalizar com outra inscrição o que, na verdade, sucedera, indo ao pormenor dos "15 palmos" de profundidade.

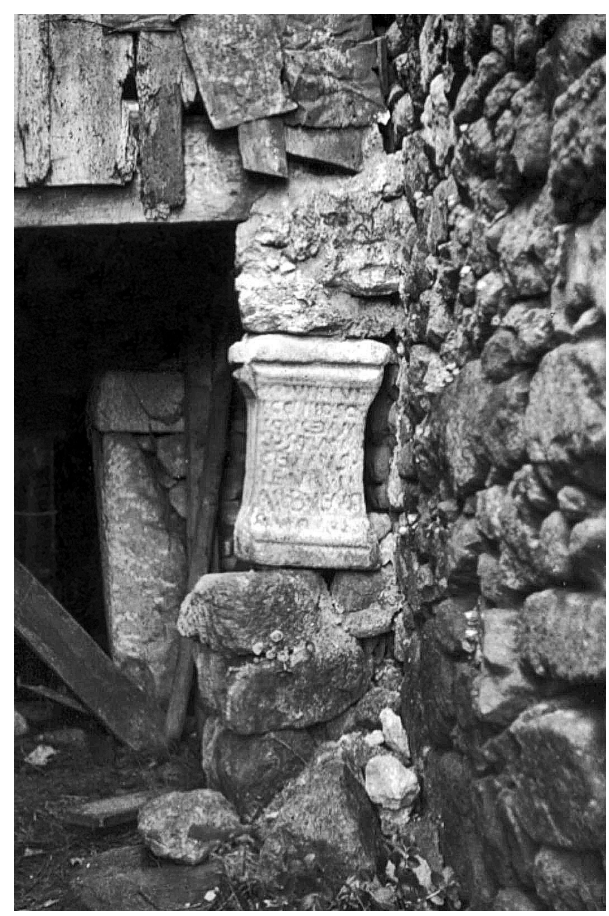

Em Braga se saberá quem foi o provedor Mota (certamente o nome está incompleto); no entanto, mesmo que nada mais dele se soubesse, o testemunho de homem culto, amante de antiguidades, estava aqui perfeitamente documentado.

Se alargarmos o conceito de «urbano" aos aglomerados populacionais do nosso interior, também neste aspecto as surpresas podem advir.

Em trabalho de campo, para levantamento de carta arqueológica, Luís Filipe Gomes e António Manuel Tavares toparam numa casa em ruínas, à 
entrada da povoação de Casais (freguesia de S. João da Fresta, concelho de Mangualde), uma ara romana, de granito, a servir de suporte a uma viga de madeira. Estava ali há anos, decerto, e ninguém se apercebera do seu real significado como documento do culto a uns Lares de estranhos epítetos indígenas. Estudaram-na, acabaram por a publicar ${ }^{7}$ e, hoje, entabuladas as devidas conversações com o proprietário, o altar encontra-se exposto, desde 1985, na sede da Associação Cultural Azurara da Beira, em Mangualde. No caso vertente, não se justificava a execução de qualquer réplica, dado que a presença da ara ali fora meramente utilitária, ocasional.

Em conclusão:

Num momento em que, um pouco por toda a parte, mercê dos mais variados circunstancialismos, os aglomerados urbanos vão sofrendo transformações, designadamente nos seus edifícios mais antigos - os tais "muros velhos" a que aludo no título -, ao arqueólogo compete uma perspicácia maior.

Robert Sablayrolles ${ }^{8}$ descobriu muito do quotidiano dos vigiles de Óstia observando miudamente os grafitos que nas paredes das suas casernas eles haviam deixado.

As cidades actuais erguidas sobre as antigas guardam no seu seio, em reaproveitamento, muitas epígrafes ("eloquentes letras").

Que atitude adoptar, então, perante uma inscrição antiga em risco de se perder?

De um modo geral, negociar a sua remoção para o museu municipal - em depósito, como donativo, por aquisição... -, deixando em seu lugar uma réplica, se disso for o caso.

Interessa é que a informação não se perca, porque, por mais insignificante que à primeira vista pareça, essas singelas letras detêm, seguramente, um dado a não perder.

\footnotetext{
${ }^{7}$ GOMES (Luís F. C.) e TAVARES (António M. M.), "Ara votiva de Casais", Ficheiro Epigráfico, 13, $1985, n^{\circ} 55$.

8 SABLAYROLLES (Robert), Libertinus Miles - Les Coortes de Vigiles. École Française de Rome, 1996.
} 


\subsection{Os cemitérios}

Se os "muros velhos" - e os novos!... - detêm preciosas informações, há lugares onde a epígrafe detém papel fundamental: os cemitérios. Neste aspecto, o epitáfio constitui uma autêntica "vitória sobre a morte".

Escreveu Celestino Costa, um canteiro de Cascais que faz jazigos, campas, epitáfios... e versos nas horas vagas:
Eu gosto tanto da vida,
E logo me calhou em sorte
Passar parte dessa vida
No território da morte. ${ }^{9}$

Assim o epigrafista e o arqueólogo: lidam diariamente com o universo da morte, que não é, convém acentuar desde já, um universo fúnebre.

Estivemos a escavar, há anos, parte do cemitério do Convento de Nossa Senhora da Piedade, em Cascais. Quem nos visitava e via os esqueletos não deixava de sentir um certo estremecimento e quedava-se admirado ao observar que nós e os nossos jovens como que "tratávamos por tu" esses restos mortais. É que, nessas alturas, quase nos apetece perguntar com S. Paulo, na sua I Carta aos Corintios (15, 55):

"Onde está, ó Morte, a tua vitória?".

Daí que, num momento em que tanto se fala da vitória da Morte, talvez não seja inoportuno reflectir em conjunto sobre a sua derrota, consubstanciada no epitáfio. O carácter implacável da morte determinou o aparecimento de formas de lhe sobreviver: o epitáfio é uma delas.

A visita a um cemitério proporciona, na actualidade como nos tempos idos, motivos profundos de reflexão, na medida em que aí nos é possível colher fla-

\footnotetext{
9 In A Minha Terra e Eu, Associação Cultural de Cascais, ${ }^{2} 1995$, p. 93.
} 
grantes da atitude do Homem perante a Morte. Talvez simultaneamente um rasgar de pistas, porque - interessados na história local, na vivência das gentes, no instantâneo significativo... - amiúde deixamos passar despercebido o insuspeitado e farto manancial histórico que constitui o mundo dos epitáfios ${ }^{10}$.

Ocorre perguntar, em primeiro lugar: qual é, afinal, a função do epitáfio?

"Salvar o nome do esquecimento", direi - usando a tão feliz expressão do meu saudoso amigo Gabriel Sanders ${ }^{11}$.

Quando entrevistava, no programa "Sexo Forte", da SIC, a 14 de Julho de 1993, uma jovem cabo-verdiana prestes a licenciar-se em Matemáticas mas que decidira dedicar os seus tempos livres à alfabetização de adultos, Paula Moura Pinheiro perguntou-lhe qual era a primeira coisa que os seus alfabetizandos queriam aprender.

- A escrever o seu nome - foi a resposta pronta.

O nome.

E a sua importância.

Nós, professores - que já fomos estudantes - sabemos quanto nos cativa, anos passados, o nosso antigo aluno ainda nos conhecer pelo nome ou quanto nos consolamos ao rever um antigo aluno cujo nome ainda não esquecemos. Há um brilho diferente nos olhos...

Tem algo de mágico o nome. Conhecê-lo como que implica posse. Daí haver cartas anónimas. Daí as bruxarias que não resultam se o nome for desconhecido. Por isso, os Romanos picavam nos monumentos o nome do imperador ou do magistrado malditos: era a damnatio memoriae. Damnatio memoriae, "condenação da memória" ou damnatio nominis - porque, apagado o nome, apagava-se a memória.

\footnotetext{
${ }^{10}$ Em finais de Outubro de 1991, estive, na companhia do Padre Belarmino Afonso, no cemitério de Bragança, por onde, após uma visita de estudo a sítios arqueológicos dos arredores e a depósitos de epígrafes romanas, nos passeámos, entre mármores e cruzes. E concluímos que também o cemitério antigo de Bragança detinha, nos seus epitáfios e nos seus monumentos funerários, informação ímpar acerca de personalidades de tempos idos.

11 SANDERS (Gabriel), "Sauver le nom de l'oubli: le témoignage des CLE d'Afrique et aliunde", L'Africa Romana 6, Sassari, 1989, p. 43-79.
} 

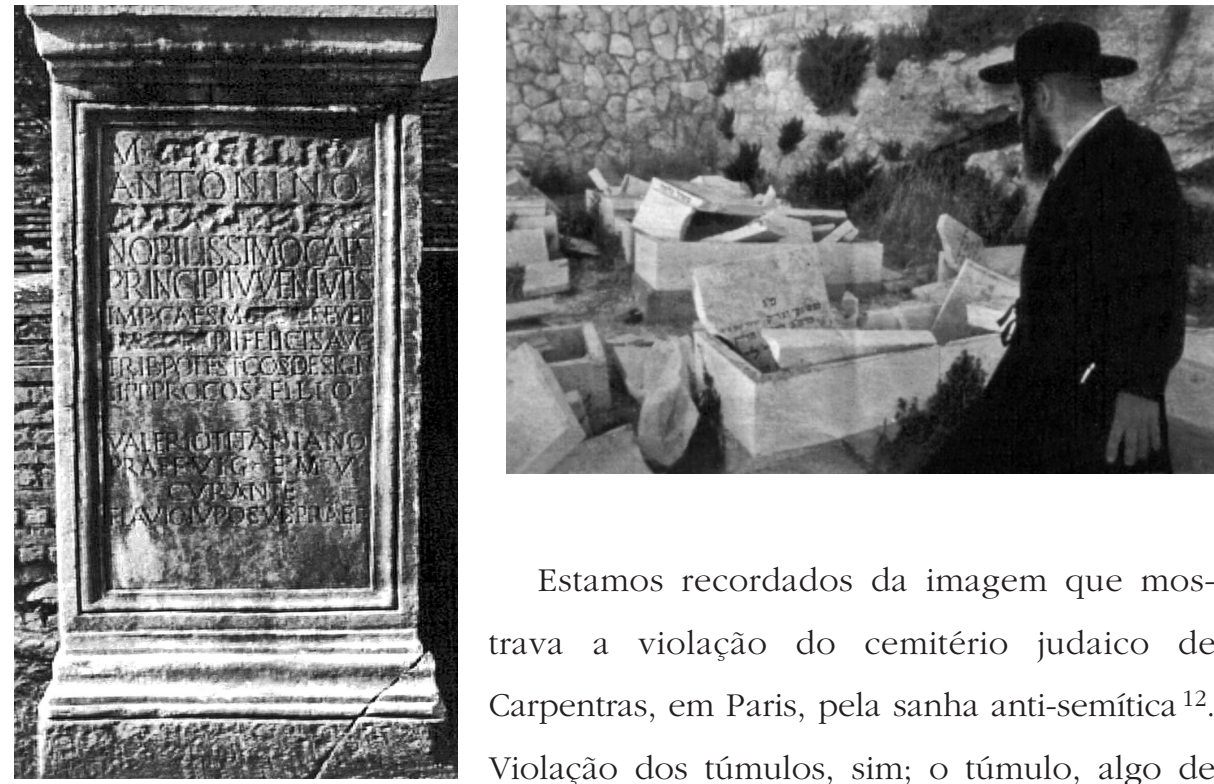

Estamos recordados da imagem que mostrava a violação do cemitério judaico de Carpentras, em Paris, pela sanha anti-semítica ${ }^{12}$. Violação dos túmulos, sim; o túmulo, algo de sagrado, de visceralmente inviolável. E destruição de epitáfios, para que até o nome desapareça.

O nome, indício de uma ideologia. Não é o baptismo, uma iniciação, acompanhado da atribuição de um nome? Não deixa o Cardeal Y de ter nome próprio para - eleito Papa - passar a ter um nome universal?

A Crónica dos Bons Malandros, de Mário Zambujal, pode ser um bom exemplo de como, em determinados ambientes, os nomes detêm significados específicos. Sabemos também que escritores, políticos, homens da Ciência, artistas dos mais variados ramos se tornam conhecidos não pelo seu nome completo (ou mesmo o verdadeiro) mas por aquele que, em gíria, se designa o "nome de guerra". Essa escolha tem, normalmente, razões profundas, umas vezes conhecidas - como é o caso do Dr. Adolfo Coelho da Rocha que preferiu ser Miguel Torga, sendo "torga" o nome de uma planta concreta com a qual ele se 'identificava' outras não.

Nas jornadas "As Oficinas da História", organizadas pela Comissão Científica do Grupo de História da Faculdade de Letras de Coimbra (2-4.XI.1999), a

${ }^{12}$ No semanário Expresso de 22.12.1990, p. 10. 
Doutora Maria José Azevedo Santos sublinhou como, doravante, em Paleografia, se está a dar uma atenção particular, nos documentos antigos manuscritos, às assinaturas dos intervenientes. Pensa-se - e com razão - que, enquanto o texto formal obedece às regras da caligrafia vigente, é na assinatura que o indivíduo se despe de regrados artificialismos e se mostra realmente como é, o que da sua personalidade quer transmitir aos vindouros.

Por outro lado, nesta globalização em que estamos envolvidos e em que o individual deseja, a todo o custo, não soçobrar, as chamadas "grandes superfícies", por exemplo, mandam pôr "etiquetas de identificação" na lapela dos seus funcionários, para que eles sejam reconhecidos; a telefonista duma importante casa comercial ou dum organismo público já declina o seu nome após a identificação da firma em que trabalha e, nas circulares que políticos e empresários nos enviam, amiúde a sua assinatura vem digitalizada agora, para, mais uma vez, haver uma identificação.

Tudo isto nos prova à saciedade a importância que, na verdade, tem o estudo do nome e, acima de tudo, a forma como ele vem escrito nas epígrafes, porque são mensagem pensada, para o futuro, conscientemente.

Poder-se-á pensar que nos estamos a afastar do tema; de pronto, todavia, se verificará que não, porque, na verdade, são os nomes o que de mais relevante há no epitáfio. Tanto do ponto de vista de vitória sobre a morte como do de história das mentalidades.

Porque, repare-se, que nomes surgem num epitáfio?

Está no museu de Elvas uma placa ${ }^{13}$ datável do século I da nossa era, cuja inscrição reza o seguinte:

Q(uintus) ATTIVS L(ucii) F( ilius) SER(gia tribu) / RVSTICVS H(ic) S( itus) $\mathrm{E}($ st $) \mathrm{S}($ it $) \mathrm{T}($ ibi) T(erra) L(evis) / NVMITORIA Q(uinti) F( ilia) MAXVMA / $\mathrm{F}$ (aciendum) C(uravit)

13 Cf. ENCARNAÇÃO (José d'), Inscrições Romanas do Conventus Pacensis (=IRCP). Coimbra, $1984, n^{-}$579, p. 644-645. 
Ou seja, em português:

Aqui jaz Quinto Átio Rústico, filho de Lúcio, da tribo Sérgia. Que a terra te seja leve. Numitória Máxuma, filha de Quinto, mandou fazer.

Perguntar-se-á:

- Quem é Numitória Máxuma?

- Porque omite o grau de parentesco com Rústico (de quem não é filha, pois não detém o mesmo gentilício)? Porque toda a comunidade conhecia esses laços e, por isso, era dispensável a sua menção? Ou porque, nessas circunstâncias, o que era público não conviria gravá-lo na pedra?

- Que mundo - outro - estará por detrás deste "esquecimento»?

De facto, há um dado a reter: no epitáfio, não figura apenas o defunto, há igualmente o dedicante. E bastas vezes apetecerá perguntar qual é, no fundo, a mensagem mais importante que se pretende fazer passar:

- a perpetuação da memória do defunto

ou

- o público reconhecimento de que alguém lhe prestou homenagem?

CARLOS MARTINS SANTOS OLIVEIRA

N. 23-1-1904

F. $10-8-1976$

ETERNA SAUDADE DE SUA

MULHER FILHOS E NETOS

Neste caso, por exemplo: apesar de todos os familiares se apresentarem anónimos (que doutra sorte não poderia ser), não se há-de ver aqui a necessidade de, embora de forma estereotipada, a família mostrar à sociedade, aos outros, que não esqueceu o ente querido?

Uma função familiar; uma função social - não há dúvida. 
Já voltaremos aos estereótipos. Mas não posso deixar de ilustrar agora, com outro documento, a eloquência do epitáfio, mesmo que desprovido de grandes discursos.

Existe no cemitério de Cascais esta inscrição em negra placa de basalto

DR. EVO FERNANDES

NASCIDO A 10-6-1944

ASSASSINADO A 21-4-1988

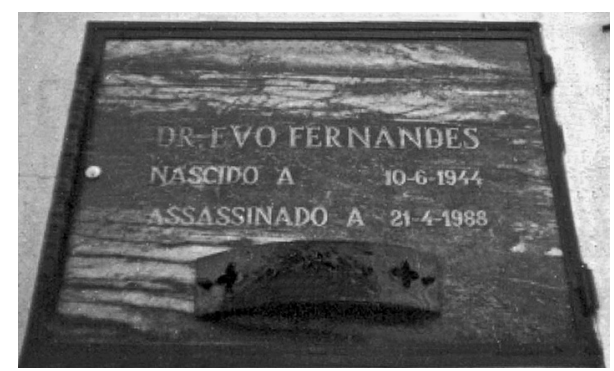

Ainda que tudo desconheçamos acerca de Evo Fernandes, a dureza do fraseado, a negrura do basalto, a inusitada menção do grau académico e a presença da palavra "assassinado" - levam-nos a uma reflexão. Pressentimos tragédia na vastidão das entrelinhas ${ }^{14}$.

Falámos de estereótipos. Frases, palavras que são lugares-comuns, desprovidas, muitas vezes, de sentido para quem as usa.

Há um outro epitáfio do cemitério de Cascais que particularmente me tocou, pelo que pode proporcionar como reflexão: um livro de mármore ostenta, na página da esquerda, quase envolvidos por quatro pés de rosa, o retrato da defunta e os seguintes dizeres:

SANDRA

ISABEL

M. B. AMORIM

* 10-11-1974

+ 26-7-1977

\footnotetext{
14 O corpo de Evo Fernandes, dirigente de um dos partidos políticos que então disputava o poder em Moçambique, foi encontrado abandonado no litoral cascalense.
} 
Na página da direita:

ANJO ADORADO

DEUS TE GUARDE

NO SEU SEIO

COMO NÓS TE

GUARDAMOS

NO NOSSO

CORAÇÃO. INFINITAS

LÁGRIMAS DE SEUS

PAIS E IRMÃ

Repare-se como a frase coloquial, expressamente pensada para este caso, na segunda pessoa, se une - inclusive sem adequada paginação - com um texto estereotipado, na terceira pessoa, como resultante da intervenção do canteiro.

Um texto a comparar com este outro, procedente de Tróia (concelho de Grândola), datável do século II ${ }^{15}$ :

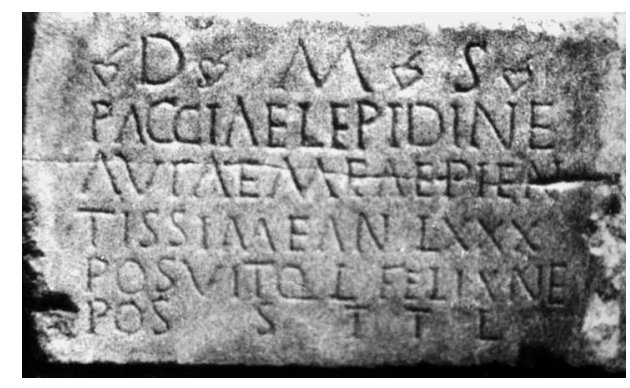

$\mathrm{D}$ (is) $\mathrm{M}$ (anibus) $\mathrm{S}$ (acrum) / PACCIAE LEPIDINE / AVIAE MEAE PIEN/TISSIME AN(norum) LXXX (octoginta) / POSVIT Q(uintus) L(icinius?) FELIX NE/POS S(it) T(ibi) T(erra) L(evis).

Consagrado aos deuses Manes. A Pácia Lepidina, minha avó, modelo de piedade, de oitenta anos. O neto, Quinto Licinio (?) Félix, colocou. Que a terra te seja leve.

\footnotetext{
${ }^{15}$ Cf. IRCP 219.
} 
Duas expressões chamaram, decerto, a atenção: "eterna saudade», "infinitas lágrimas". Quando manda rasgar a pedra para nela gravar uma mensagem, o dedicante acredita que é eterna, para sempre.

Por isso, há quem se antecipe e mande gravar em vida o epitáfio ou cuide do seu próprio sepulcro:

\section{L(ucius) MELIVS \\ C(aii) F(ilius) VOLT( inia tribu) \\ PATERNVS}

VIVVS SIBI

"Lúcio Mélio Paterno, filho de Gaio, da tribo Voltínia, vivo, para si" - lê-se numa pedra, datável do século I, patente no Museu Arqueológico de Nîmes.

Já Trimalquião, a célebre personagem do Satíricon de Petrónio († 66 d. C.), que se diz douto nas letras epigráficas («lapidarias litteras scio»), embora menospreze as outras («Nunca fui aluno dos filósofos»...), dá instruções precisas a Habinas para que lhe construa o túmulo como lhe encomendou:

- Peço-te insistentemente que, aos pés da minha estátua, representes a minha cadelinha, coroas, perfumes e todos os combates de Petraites, para que, graças a ti, eu continue a viver depois da minha morte. Além disso, quero que haja cem pés de fachada, duzentos de profundidade. Quero também toda a espécie de árvores de fruto à volta das minhas cinzas e muitas vinhas. Com efeito, é um grande erro ter, em vida, uma casa bem fornecida e não se ocupar daquela onde teremos de habitar mais tempo. É por isso que, acima de tudo, quero que se acrescente: "Este monumento não faz parte da herança». ${ }^{16}$

\footnotetext{
16 Segui a tradução de Jorge de Sampaio, publicada na colecção Livros de Bolso de Publicações Europa-América, no 68, Mem Martins, 1993, cap. 71, p. 78.

A propósito do que pitorescamente Petrónio põe na boca de Trimalquião quanto às características do seu monumento funerário, importará dizer que tal não é tão invulgar assim. Na verdade, numa inscrição romana de Spinazzola (Bari), enumeram-se os elementos constituintes de um domínio funerário completo, que compreendia uma pequena casa destinada ao guarda (domus), o túmulo propriamente dito (sepulchrum), cuja manutenção era assegurada pelos rendimentos de um campo (ager) e de um horto (bortus). Aliás, aí se acrescenta que o defunto - neste caso, um médico, Cléon de seu nome - leva para a última morada (bic) a recordação dos prazeres que conheceu durante a vida. Cf. L'Année Épigraphique (=AE), 1985, 297.
} 
Daí as confrarias fúnebres, tanto nos tempos de Roma como na actualidade: surpreendi, junto da sé de Braga, uma velhinha tabuleta de mármore a sinalizar a secretaria da Associação de S(ocorros) M(útuos) Fúnebre Familiar Bracarense.

Daí as disposições testamentárias ${ }^{17}$ - que têm frequentemente como contrapartida, ao tempo dos Romanos, a libertação de escravos. É o que documenta este bloco ${ }^{18}$ que está no Museu do Fundão, proveniente de Freixial, freguesia de Telhado, desse concelho:

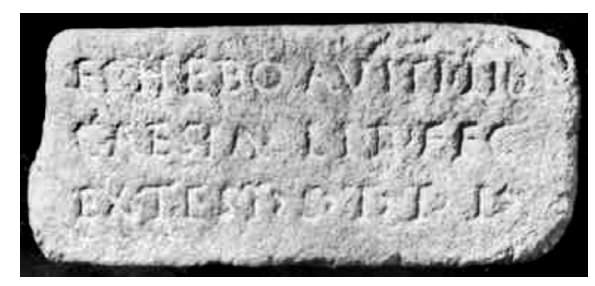

EPHEBO AVITI LIB(erto)

CAESIA LIB( erta) FEC( it)

EX TEST(amento) S(it) T(ibi) T(erra) L(evis)

A Efebo, liberto de Avito. Césia, liberta, fez, por testamento. Que a terra te seja leve.

Por vezes, enganam-se. Uma eternidade fictícia:

- basta visitar, em Paris, o cemitério do Père Lachaise para ver o estado de ruína em que se encontram muitos jazigos, inclusive de gente célebre;

- basta recordar os anúncios que, de vez em quando, os jornais publicam de jazigos abandonados;

- basta lembrar como a imprensa se faz eco do desmazelo em que está este ou aquele monumento de homens ilustres.

Por vezes, acredita-se piamente que outros completarão o que falta. Piamente.

E posso aduzir como exemplo a placa de um jazigo achada em Vaiamonte ${ }^{19}$.

17 Cf. MARCOS (Rui Manuel de Figueiredo), "Em torno do "Ius Sepulchri" romano - alguns aspectos de epigrafia jurídica", Boletim da Faculdade de Direito da Universidade de Coimbra, LXIII, 1987, p. 153-182.

18 Cf. VAZ (João Luís), "Inscrições romanas do Museu do Fundão”, Conimbriga, XVI, 1977, p. 17 (=AE 1977 360).

19 IRCP 578. 
Data dos primórdios do século I da nossa era. O marido morreu e a mulher apressou-se a mandar erguer sepulcro para os dois, com o correspondente epitáfio, onde incluiu o seu nome, Aquília Cara, e o voto final: "Que a terra vos seja leve». Deixou,

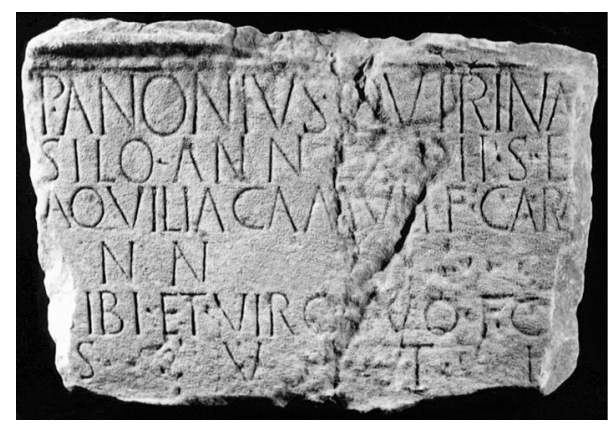
porém, em branco, na quarta linha, o espaço para aí ser gravada a idade com que viesse a falecer e a fórmula $S($ ita $) \mathrm{E}(\mathrm{st})$, "aqui jaz". Apenas sucedeu o inesperado: ninguém preencheu a linha!...

Uma outra palavra-tipo nas inscrições funerárias romanas é pientissimus, "modelo de piedade".

A pietas era uma qualidade moral da maior importância para os Romanos: significava a dedicação aos seus, ao próximo, ao Estado, aos deuses. O maior elogio que se fazia a alguém ${ }^{20}$. E poder-se-á estranhar que todas as mulheres e todos os maridos sejam "modelos de piedade" (quando morrem...). É que o superlativo detém, neste contexto, um significado propiciatório: o elogio exerce sobre o defunto uma função apaziguadora, 'convence-o' da sua bondade e 'impede-o' de vir importunar o mundo dos vivos.

Isto leva-me a falar do diálogo entre os vivos e os mortos.

Sirva-nos de testemunho o epitáfio de Comínia Avita, falecida com nove anos de idade, mandado lavrar por seus pais - há dois mil anos atrás - Marco Comínio Clemente e Víbia Avita ${ }^{21}$. Achado na freguesia de Santo Ildefonso, concelho de Elvas, o texto traz um pedido:

$\mathrm{T}($ e) $\mathrm{R}$ (ogo) $\mathrm{P}$ (raeteriens) $\mathrm{D}($ ic $) \mathrm{S}($ it $) \mathrm{T}($ ibi) $\mathrm{T}($ erra) $\mathrm{L}($ evis $)$

«Rogo-te, ó passante, dize: 'Que a terra te seja leve!’.

20 Cf., de Maria Helena Rocha PEREIRA, Estudos de Cultura Clássica, II volume - Cultura Romana, Fundação Calouste Gulbenkian, Lisboa, 1984, p. 326-330.

21 Cf. IRCP 583. 
O uso de siglas prova que se trata de fórmula habitual. A utilização da segunda pessoa revela intimidade. A adopção da forma verbal no presente assim como a deliberada ausência de cronologia relativa constituem marcas evidentes de que se pretende uma intemporalidade, uma presença constante ${ }^{22}$.

Veja-se como, ao invés, nos epitáfios cristãos, além da menção da idade, se explicita claramente o dia em que o óbito ocorreu, porque esse dia há-de ser recordado como o primeiro da vida verdadeira, a do Além, a da comunhão com Deus $^{23}$ :

"Festelo, servo de Deus, viveu seis anos; descansou na paz de Deus no $7^{\circ}$ dia das calendas de Março de 565. Ora por mim"

- reza um epitáfio de Mértola, datado de 23 de Fevereiro de $527^{24}$.

"Descanse em paz" (D. E. P. - como se lê nas lousas do cemitério de S. Brás de Alportel) é o correspondente cristão e português do sit tibi terra levis romano, que tem, curiosamente, na ideologia muçulmana, um equivalente pleno de poesia e de significado: "Que as nuvens reguem a tua tumba!»...

Sempre, contudo, a mesma ideia de comunicabilidade entre o passante e o morto. Um chamar de atenção que pode assumir o pedido duma prece pelo seu eterno repouso, uma vez que há memórias funerárias com as siglas P. N. A. M. - na súplica de que, pela alma, se reze devoto padre-nosso e uma ave-maria sentida...

Nas poesias, essa referência pode ser ainda mais explícita, como se pode ver no célebre epitáfio de Cláudia, do século II a. C., que Maria Helena da Rocha Pereira saborosamente traduziu ${ }^{25}$ :

\footnotetext{
22 Sobre este tema e no que respeita ao território hispânico, poderá ver-se a notável síntese elaborada por Ana Paula FERREIRA, "As saudações do Além entre os Romanos", Conimbriga, 35, 1996, p. $107-127$.

${ }^{23}$ Cf. CAESSA (Ana Isabel de Sá), "Viver docemente e descansar em paz!", Jornal de Coimbra, 27 de Julho de 1988, p. 21.

${ }^{24}$ Estudado por Maria Manuela Alves DIAS e Cláudio TORRES, "O epitáfio paleocristão de Festellus (Mértola)", Ficheiro Epigráfico, 41, 1992, no 181.

25 In Romana (Antologia da Cultura Latina), Coimbra, ${ }^{3} 1994$, p. 13.
} 
Estrangeiro, pouco tenho para dizer; pára e lê.

Este é o sepulcro não pulcro de uma pulcra mulher.

Cláudia foi o nome que lhe puseram seus pais.

Ao marido amou de todo o seu coração.

Filhos, criou dois. Destes, a um,

Deixou sobre a terra, o outro sob ela.

Aprazível a sua fala, gracioso era o seu andar.

Cuidou da sua casa, fiou lã. Disse. Podes ir-te.

Um texto significativo, que mostra como os epitáfios podem analisados, inclusive, do ponto de vista literário e filosófico ${ }^{26}$. Um texto culto, porém. Será essa a norma? Será apanágio das classes elevadas o emprego da poesia tumular? ${ }^{27}$

A questão prende-se com a pergunta inicial: qual a razão de ser do epitáfio? Porque é que há imponentes jazigos que ostentam apenas um nome? É que as "personalidades" detiveram outros meios de se perpetuar. É ao homem comum que só uma alternativa resta: o epitáfio. Daí os versos populares. De pé quebrado, de paginação heterodoxa, mas duma singeleza extrema:

\author{
LINDO BOTÃO \\ DE CRAVO FLORIU QUE \\ TÃO CEDO DESFOLHOU \\ TINHAS TÃO BOM CORAÇÃO \\ QUE DEUS PRÓ CÉU
}

TE LEVOU

- lê-se numa lápide do cemitério de Bragança.

\footnotetext{
${ }^{26}$ Realce-se, nesse domínio, o labor ímpar de Lidia Storoni Mazzolani, cuja obra assenta, em boa parte, na interpretação do que pode estar por detrás de um singelo epitáfio ou de mero elogio fúnebre. Na impossibilidade de se referirem, aqui, todos os livros sobre esta temática, faço menção de dois: Iscrizioni Funerarie Romane, Biblioteca Universale Rizzoli, Milão, 1991 (cf. Conimbriga, 31, 1992, p. 197-200); Una Moglie, Sellerio editore, Palermo, 1982.

27 É prevalentemente negativa a resposta a essa questão, como sabiamente o demonstrou Maria Micaela SOARES: "Epigrafia tumular moderna no concelho de Azambuja", Boletim Cultural da Assembleia Distrital de Lisboa, no 92, 1o tomo, 1990/1998, p. 155-200.
} 
E as frases que são prosa mas...:

DO NOSSO HOMEM GRANDE E

- saudação ao Zezinho, de Castro Laboreiro, falecido a 5-7-80, com cinco anos por completar.

Em termos de inultrapassável concisão, termina assim um epitáfio romano de Ourém:

\section{VENISTI}

AVE

LEGISTI

SALVE

«Olá, tu que chegaste! Já leste? Passa bem!» 28

\section{EPIGRAFIA EM PORTUGAL}

\subsection{Ciência antiga, rumos novos}

Ciência que interpreta, como vimos, os textos gravados em materiais duradouros, para os utilizar como relevante fonte histórica, a Epigrafia conheceu, desde o Humanismo, importantes cultores entre nós.

André de Resende (c. 1500-1573) deixou-nos, entre outras obras, a História da Antiguidade da Cidade de Évora (Évora, 1553) e os Libri Quattuor de Antiquitatibus Lusitaniae publicados postumamente por Diogo Mendes de Vasconcelos (Évora, 1593). Norteado pelo ideal humanista de ligar à história romana o nosso passado remoto, André de Resende colheu nos clássicos, e

28 Cf. João COSTA, "Inscrição funerária de Vila Nova de Ourém (Conventus Scallabitanus)", Ficheiro Epigráfico, 8, 1984, no 34 (= AE 1984 477). 
comentou, todas as passagens que à Lusitânia se pudessem, de perto ou de longe, referir, corroborando-as, sempre que possível, com dados arqueológicos concretos. Tudo o que era antigualha ou vetusta pedra escrita ciosamente guardou, recuperou e deu a conhecer. Deslumbrado pelas lendárias lutas de Viriato e, sobretudo, de Sertório, ele que era natural de Évora não podia deixar de as aproveitar historicamente, para fazer da cidade o centro das operações bélicas de antanho. Faltavam-lhe os elementos palpáveis? Não bastavam as muitas epígrafes autênticas que recolheu? Não hesitaria em forjar outras! Assim, da sua pena e das mãos de artífices por ele bem treinados viriam a sair textos e monumentos epigráficos, onde, muita vez, só um inocente toque de erudição renascentista deixa transparecer a falsidade:

"A Júpiter Óptimo Máximo. Por terem sido vencidos, por Q. Sertório, Metelo e Pompeu - Júnia Donace trouxe como presente uma coroa e um ceptro em prata e a fíala cinzelada à flamínia e ofereceu uma ceia aos escravos do templo".

Ou esta outra:

«Pela saúde e pela estabilidade da casa de Quinto Sertório, Júnia Donace, sua doméstica, e Quinto Sertório Hermes e Quinto Sertório Cepalo e Quinto Sertório Anteros, seus libertos, à honra dos deuses Lares, em o dia da festa chamada Compitália, fizeram jogos públicos e deram convite a todos os vizinhos".

O texto foi forjado para demonstrar que Sertório tomara assento em Évora, por "ser de nobre e grande povo" "e também por esta cidade ser em meio da Lusitânia"; aí fizera "Sua casa", "em a qual tinha uma mulher, sua doméstica, e três libertos que com ele estavam".

Valerosos lusitanos que não deram tréguas à Roma sublime. O prestígio humanista da cultura romana era, pois, um pretexto mais para realçar a importância das nossas tradições. 
Isso compreendeu, de pronto, Frei Bernardo de Brito (1569-1617), em cujas mãos a epigrafia romana - pelo seu excepcional valor documental - conheceu incremento ainda maior. Frei Bernardo de Brito não só utilizou, sem qualquer 46 espírito crítico (que lhe não interessava tê-lo), os textos transmitidos por André de Resende, como ele próprio outros fabricou, no fito de melhor enaltecer a tradicional rebeldia dos Portugueses, que ora interessava alevantar contra a pesada tirania espanhola:

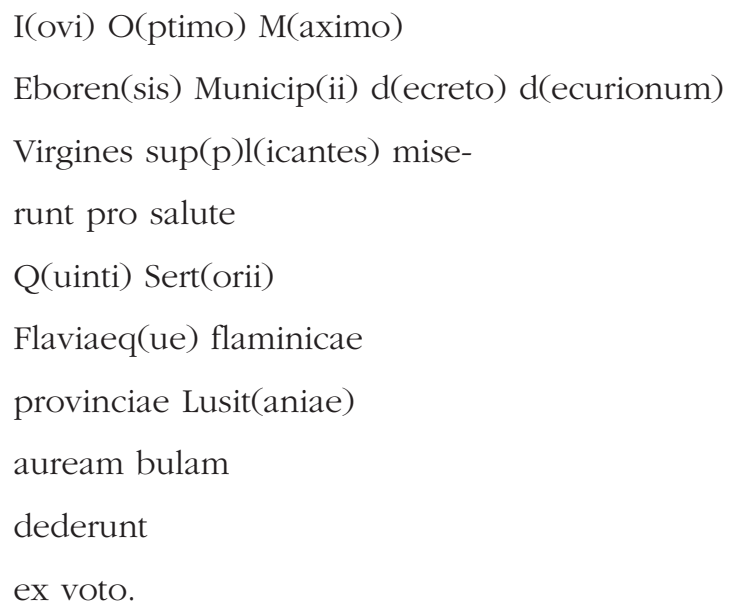

"Quer dizer - explica B. de Brito (Monarquia Lusitana I 1597 f. 290) - que a cidade de Évora, por parecer dos homens do governo, mandara as moças solteiras dar graças ao soberano Júpiter, pela saúde e bom sucesso de Sertório e deram a Flávia, que era flamínia ou sacerdotisa da província de Portugal, uma jóia de ouro, que tinham prometido".

E é o próprio Frei Bernardo de Brito quem, habilidosamente, começa por pôr em dúvida a autenticidade do texto que forjara a partir doutros, dizendo: "Outra pedra traz o prontuário de letreiros, que tenho a este propósito, a qual referirei sobre sua consciência, inda que a não vi, nem Resende a traz" - para logo acrescentar: «E o que me faz ter este letreiro por mui certo é o nome da sacerdotisa, que está em outro, citado por Resende e se vê hoje em dia na própria igreja (...)". 
Mas também a Academia Real de História, criada em 1720, desempenhou relevante papel neste domínio. Recordemos, nomeadamente, que foi por sua iniciativa que se publicaram, entre 1732 e 1747, os quatro volumes das Memorias para a Historia Ecclesiastica do Arcebispado de Braga, da autoria de D. Jerónimo Contador de Argote, com muitas notícias de inscrições. A Colecçam dos Documentos e Memorias da Academia Real da Historia Portugueza (17211736) merece igualmente uma leitura atenta.

Dessa época é também Frei Manuel do Cenáculo (1724-1814). Lente em Coimbra, activo colaborador das reformas pombalinas, sócio da Academia Real das Ciências (criada em 1779), Frei Manuel do Cenáculo aproveitou o relativo sossego que o seu afastamento da Corte (após a queda de Pombal) lhe proporcionou, para, como bispo de Beja (a partir de 1770) e, de 1802 em diante, como arcebispo de Évora, reunir uma interessante e variada colecção lapidar que se deu ao trabalho de cuidadosamente desenhar. Havia aí de tudo e de várias épocas: esculturas romanas e medievais, vasos cerâmicos e de metal, fragmentos arquitectónicos, textos em escrita ibérica, inscrições romanas, epitáfios cristãos, letreiros árabes... À Biblioteca Pública de Évora, que fundou, viria a doar esses preciosos álbuns, onde ainda hoje se podem consultar. Comparando os monumentos existentes com os desenhos do arcebispo, salta facilmente à vista a sua absoluta fidelidade ao modelo, o que é para nós da maior garantia em relação aos monumentos actualmente perdidos. Sabia, decerto, Frei Manuel do Cenáculo a importância da sua recolha, do seu trabalho; talvez tivesse em mente vir a publicar depois as leituras das epígrafes, a interpretação dos monumentos desenhados. Não chegou, porém, a fazê-lo. E figurará, portanto, na história da Epigrafia em Portugal como o grande coleccionador atento e diligente.

Outro tanto fazem seus confrades académicos, que se apressam a apresentar às sessões da Academia dezenas de antiguidades, entre as quais muitas inscrições romanas. O duque de Lafões é um deles; outro, Frei Joaquim de Santa Rosa de Viterbo que, no seu Elucidário das palavras, termos e frases que em Portugal antigamente se usaram... (Lisboa, 1798), não se esquece de anotar, em cada artigo, as inscrições que lhe dizem respeito: por exemplo, no artigo 
"Numan", o monumento aos deuses e deusas de Conímbriga aí encontrado. E, hoje, as Memorias de Litteratura Portugueza (1792-1821), a Historia e Memorias da Academia Real das Sciencias de Lisboa (1843-1856) e as Memorias da Academia Real das Sciencias de Lisboa (nova série, a partir de 1854) são, ainda, de consulta obrigatória para a especificação duma proveniência, para a confirmação de leitura dum monumento perdido.

Era o prenúncio da intensa curiosidade científica que a Epigrafia, designadamente a Epigrafia Romana, iria despertar no séc. XIX.

E será ainda uma academia, a Academia das Ciências de Berlim, que chamará a si a tarefa de reunir num monumental corpus, segundo critérios comprovadamente científicos, todas as inscrições conhecidas do mundo romano. Os volumes foram organizados geograficamente: do II, referente aos textos da Península Ibérica, ficaria encarregado Emílio Hübner.

Hübner visitou Portugal durante o ano de 1861. Viu museus, recolheu ampla bibliografia impressa e manuscrita, relacionou-se com os nossos académicos. Desse primeiro e fugaz contacto apresentou circunstanciado relatório, as Noticias Archeologicas de Portugal, que viria a ser publicado, com tradução de A. Soromenho, "por ordem da Academia Real das Ciências de Lisboa", em 1871. Sistematizados os materiais, a Academia publicou, em 1869, o primeiro tomo do Corpus Inscriptionum Latinarum II (= CIL II) ${ }^{29}$.

Nessa altura, porém, já Francisco Martins Sarmento (1833-1899) se interessava, no Norte do País, pelas antiguidades "célticas" e romanas; e Gabriel Pereira (1847-1911) iniciava, em Évora, as pesquisas que levariam à publicação dos Estudos Eborenses. A publicação do CIL teve o condão de despertar para os monumentos epigráficos a atenção dos nossos «amantes da Antiguidade". Tornaram-se mais frequentes os contactos com a Academia de Berlim, na sequência da iniciativa de Hübner. Novos textos são dados a conhecer. Fazem-se outras leituras, mais correctas.

\footnotetext{
${ }^{29}$ Sobre a actividade desenvolvida por Emílio Hübner, cfr. a notável síntese de Patrick LE ROUX, "Émile Hübner ou le métier d'épigraphiste", Épigraphie Hispanique, Paris, 1984, p. 17-31.
} 
O último quartel do séc. XIX é - como, aliás, por toda a Europa - período de intensa actividade científica, designadamente arqueológica. Francisco Martins Sarmento funda em Guimarães, no ano de 1882, uma sociedade arqueológica com o seu nome, a qual começa de imediato a reunir, num depósito-museu, materiais arqueológicos, entre os quais inscrições, publicadas no seu órgão oficial, a Revista de Guimarães (vol. I, 1884). Em Lisboa, a Real Associação dos Architectos e Archeologos Portuguezes iniciara, em 1874, com o nome de Boletim de Architectura e de Archeologia, a publicação da $2^{2}$ série da sua revista; A. C. Borges de Figueiredo dirige, de 1887 a 1889, a Revista Archeologica e Historica, onde inclui o estudo de numerosas inscrições. Ensaiavam-se, por seu turno, os primeiros passos no domínio da filologia científica, com Adolfo Coelho (1847-1919) e Leite de Vasconcelos (1858-1941) - que daria corpo à Revista Lusitana, apresentada como "Archivo de Estudos Philologicos e Ethnologicos relativos a Portugal» (vol. I, Porto, 1887-1889). Estácio da Veiga, membro da Academia das Ciências, percorre o Sul do território nacional, cujas "antiguidades monumentais" dá a conhecer ${ }^{30}$.

Desta sorte, foi grande o acervo de novos monumentos epigráficos. Hübner correspondia-se amiúde com os sábios portugueses ${ }^{31}$. Por isso vem a lume, em 1892, o suplemento de CIL II, publicação que provoca novo entusiasmo entre os investigadores portugueses. O próprio Hübner o confessa - e com isso se regozija - no prefácio aos "Additamenta nova ad Corporis volumen II", incluídos na revista Ephemeris Epigraphica VIII, 1896: "Crescit in dies numerus virorum in paeninsula Iberica vel doctorum vel indoctorum, qui studio laudabili patrias antiquitates amplectuntur" ${ }^{32}$. É que, além da Revista de Guimarães, começara a publicar-se, em 1895, O Archeologo Portuguez, com uma regularidade impressionante, por

30 Sobre a actividade arqueológica de Sebastião Philippes Martins Estácio da Veiga, ver: Maria Luísa E, da V. Affonso dos SANTOS, Arqueologia Romana do Algarve, I, Lisboa, 1971, p. 51-54, e Maria Luísa Estácio da Veiga Silva PEREIRA, Estácio da Veiga, Casa do Algarve, Lisboa, 1985 (XVII vol. dos Estudos Algarvios). Prepara-se para 2006, em Silves, uma reunião científica exclusivamente dedicada a este homem de ciência, inclusive com a publicação de um V volume das Antiguidades.

31 Veja-se, a título de exemplo, Correspondência epistolar entre Emílio Hübner e Martins Sarmento, coligida e anotada por Mário Cardozo, Guimarães, 1947.

32 "Cresce de dia para dia, na Península Ibérica, o número de homens, doutos e incultos, que se interessam, com louvável dinamismo, pelas antiguidades pátrias". 
iniciativa de José Leite de Vasconcelos, que, entretanto, já promovera a fundação, em Lisboa (1893), dum museu etnológico com o seu nome (hoje, Museu Nacional de Arqueologia) e principiara a coligir elementos para a sua monumental obra Religiões da Lusitânia: o $1^{\circ}$ volume (religiões pré-históricas) sairia em 1897; o 2º, dedicado à religião pré-romana e baseado fundamentalmente na epigrafia, será publicado em 1905; e o 3ํㅡㄹ versando a religião dos Romanos, em 1913. Era a primeira grande obra a utilizar sistematicamente os dados epigráficos como fonte histórica para gizar uma panorâmica do quadro religioso da Antiguidade ${ }^{33}$.

Outros arqueólogos se dedicam, entretanto, à publicação dos monumentos epigráficos que vão encontrando: Albano Bellino, na região de Braga; António dos Santos Rocha, que fundara na Figueira da Foz uma sociedade arqueológica com o seu nome; Félix Alves Pereira, sobretudo na região beirã; o Pe Francisco Manuel Alves (Abade de Baçal), em Trás-os-Montes ${ }^{34}$.

Hübner faleceu em 1901; no entanto, os materiais que coligira foram apresentados por H. Dessau em novo volume de "Additamenta" (Ephemeris Epigraphica IX, 1903).

E é, sem dúvida, a figura de Leite de Vasconcelos (falecido em 1941) que, no campo da Epigrafia, preenche quase por completo a primeira metade do séc. $\mathrm{XX}$, quer como director do seu museu quer mediante a publicação d'O Archeologo Portuguez 35 .

Finda a Segunda Grande Guerra, os estudos epigráficos ganham, necessariamente, novo alento. Continua a pesquisa (digamos assim) regional, agora levada a cabo, por exemplo, por Abel Viana (1896-1964) no Alentejo (o I volume do Arquivo de Beja é publicado em 1944); por José Coelho em Viseu; pelo pe Eugénio Jalhay um pouco por toda a parte ${ }^{36}$.

\footnotetext{
33 Sobre a importância desta obra, veja-se o comentário de José Manuel GARCIA, "Sobre as Religiōes da Lusitânia, Prelo, Lisboa, 2, Jan./Mar. 1984, p. 111-119, a propósito da sua reimpressão fac-similada pela Imprensa Nacional - Casa da Moeda (Lisboa, 1981).

${ }^{34}$ Cf. "Abade de Baçal, epigrafista", Actas do Colóquio O Abade de Baçal, Bragança, 1999, p. 17-23.

35 Bastará compulsar o tomo I dos índices dos volumes I-XXX (1895-1938), publicado pelo Museu Nacional de Arqueologia e Etnologia, para disso facilmente nos apercebermos.

36 Para a bibliografia destes investigadores, bem como dos que adiante se citam, importa consultar: o catálogo bibliográfico A actividade arqueológica em Portugal-Cem anos de publicações 1880-1980, apresentado em Lisboa aquando da realização do III Colóquio Internacional sobre
} 
É, porém, na década de 50, que a Epigrafia Romana conhece um decisivo impulso. Além de se preconizar um regresso à pedra para, com melhores fotografias e decalques, se encontrar a leitura exacta, o avanço dos conhecimentos permite comparações que dão a cada monumento uma dimensão histórica maior.

Nesse movimento ocupa lugar de relevo Scarlat Lambrino (1891-1964) ${ }^{37}$, professor de Epigrafia na Faculdade de Letras de Lisboa. Lambrino prepara os catálogos do Museu Nacional de Arqueologia e Etnologia e do Museu de Odrinhas e, fundado nas novas leituras, lança ombros a trabalhos de reflexão e síntese (sobre divindades, governadores da Lusitânia, povos...), propósito indispensável que só a morte, prematura, não deixou desenvolver. Prosseguiu-o, devotadamente ainda que com menos fôlego, o seu directo colaborador, D. Fernando de Almeida, insigne Mestre a cujo entusiasmo e nunca desmentida dedicação devo o ter procurado especializar-me em Epigrafia ${ }^{38}$.

Datam também de finais da década de 50 os primeiros trabalhos de revisão de leituras efectuados por Justino Mendes de Almeida e por Fernando Bandeira Ferreira ${ }^{39}$, enquanto que, no Norte, Mário Cardozo (1889-1982) se afirmava como o grande continuador de F. Martins Sarmento ${ }^{40}$ e D. Domingos de Pinho Brandão aproveitava o seu múnus pastoral para dar a conhecer numerosos monumentos epigráficos dispersos ${ }^{41}$.

Será, todavia, na década de 70 que esta ciência antiga tomará novos rumos em Portugal.

O incremento de salutar intercâmbio com os investigadores estrangeiros; a crescente permuta das nossas revistas com revistas da especialidade; o interesse

Línguas e Culturas Páleo-hispânicas (1980); e, sobretudo, a Bibliografia Arqueológica Portuguesa (1935-1969), de Eduardo Pires Oliveira, Lisboa, 1984. Sobre a obra de Abel Viana, ver a síntese de Octávio da Veiga Ferreira na Revista de Guimarães 741964 172-176.

37 A evocação da sua memória foi feita por Fernando de Almeida no Archivo Español de Arqueologia 371964 206-207.

38 Cf. o meu testemunho "D. Fernando de Almeida, o mestre, o epigrafista", Eburobriga 3 (Primavera/Verão 2005) 35-39.

39 Tive ensejo de me referir à actividade, como epigrafista, de F. Bandeira Ferreira, na sessão efectuada em sua homenagem na Secção de Arqueologia da Sociedade de Geografia de Lisboa, a 16 de Junho de 2004. O texto, intitulado "Bandeira Ferreira, um labor de epigrafista", foi publicado no Boletim da Sociedade de Geografia de Lisboa, série 122ª , nos 1-12 (Jano/Dez 2004) 111-120.

${ }^{40}$ Cfr. a sua Biobibliografia, publicada em 1972 pela Sociedade Martins Sarmento.

${ }^{41}$ Cfr. José d'ENCARNAÇÃO, "Pinho Brandão, epigrafista”, Lucerna, Porto, 1984, p. 203-211. 
manifestado por epigrafistas europeus, designadamente franceses, espanhóis e alemães em relação aos monumentos do nosso território; a possibilidade de, mediante a reestruturação dos cursos universitários, a Epigrafia passar a ser cadeira anual - são alguns dos factores responsáveis por esses novos rumos.

Veio a lume, em 1976, o tomo II das Fouilles de Conimbriga, dedicado precisamente à epigrafia desta cidade romana. E acabara de criar-se, na Faculdade de Letras de Coimbra, a Pré-Especialização em Arqueologia, em cujo currículo a Epigrafia figurava como disciplina anual e obrigatória. Tivemos a sorte de nos encarregarem de reger a cadeira, em condições altamente favoráveis e a estudantes particularmente dotados e receptivos, de maneira que cedo a revista Conimbriga passou a incluir regularmente artigos de Epigrafia.

O monumento epigráfico era, agora, visto na sua totalidade, integrado num contexto arqueológico, como objecto cultural onde tudo foi pensado: o texto, sintético, intencional, preciso; a decoração; a tipologia; o material ${ }^{42}$.

E o aparecimento, em cada vez maior número, de novos documentos, mercê sobretudo do trabalho de campo levado a efeito por estudantes universitários e pelos membros das associações de defesa do património - quantas inscrições romanas não estavam à vista de todos, há longos anos, e ninguém as procurava decifrar!... - postulou, inclusive, a edição dum suplemento à revista Conimbriga, a que demos o nome de Ficheiro Epigráfico, com a finalidade de inserir, rapidamente, nos circuitos científicos as epígrafes inéditas que se encontrarem e para se evitar a dispersão de publicações. Elabora-se como que uma ficha de cada uma: descrição do monumento, local de achado, paradeiro actual, leitura e comentário a sublinhar o seu interesse histórico. O Ficheiro Epigráfico não tem periodicidade rígida, dependendo a sua saída do número de inscrições que forem presentes aos coordenadores. O primeiro número saiu durante o primeiro semestre de 1982 e chegar-se-á, em 2005, ao nº 80 3․

\footnotetext{
42 Cfr. José d'ENCARNAÇÃO, "Epigrafia, uma leitura diferente», Munda, Coimbra, 7, 1984, p. 3135. Reproduzido em Estudos sobre Epigrafia, Coimbra, 1998, p. 7-14.

43 Cf. a síntese que sobre ele publiquei: "Ficheiro Epigráfico - uma experiência em curso em Portugal", Trabalhos de Antropologia e Etnologia 271988 245-247. Os volumes 1 a 66 foram também editados em CD-ROM (2003).
} 
Falámos, sobretudo, da Epigrafia Romana, que mais atenção tem merecido. Mas desde cedo as estelas epigrafadas da I Idade do Ferro do Sul de Portugal despertaram igualmente o interesse dos nossos historiadores.

Foi exactamente Frei Manuel do Cenáculo o primeiro que cuidadosamente as desenhou. Esta indecifrada escrita do Sudoeste peninsular é domínio particularmente caro aos linguistas espanhóis, como o demonstram os colóquios internacionais de Línguas e Culturas Páleo-hispânicas ${ }^{44}$, de que, porém, os investigadores portugueses, como Caetano de Melo Beirão ${ }^{45}$, Amílcar Guerra e Virgílio Hipólito Correia ${ }^{46}$ se não têm alheado, mormente na elaboração das primeiras sistematizações dos sinais gráficos utilizados.

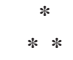

Comparativamente, não têm sido tão frequentes os achados de epigrafia cristã. Foi, realmente, excepção a descoberta, em Mértola, de cinco novos epitáfios do séc. VI, estudados por Manuela Alves Dias e Cláudio Torres (Ficheiro Epigráfico 91984 n ${ }^{\text {os }}$ 35-39).

Hübner incluíra nas Inscriptiones Hispaniae Christianae (Berlim, 1871) todos os textos então conhecidos. E o Pe Miguel de Oliveira publicou, em 1941, o primeiro grande catálogo, sob o título Epigrafia Cristã em Portugal. Inscripciones Cristianas

\footnotetext{
${ }^{44}$ Estes colóquios têm-se realizado com regularidade e as suas actas editadas também sem detença. O I foi em Salamanca, em Maio de 1974: Actas del I Colóquio sobre Lenguas y Culturas Prerromanas de la Península Ibérica, Salamanca, 1976; o II em Tübingen, em 1976: Actas del II Colóquio sobre Lenguas y Culturas Prerromanas de la Península Ibérica, Salamanca, 1979; o III em Lisboa (Novembro de 1980): Actas del III Colóquio sobre Lenguas y Culturas Paleohispanicas, Salamanca, 1985; o IV em Vitória: actas publicadas no volume 2-3 (1985-1986) da revista Veleia, editada pela Universidade do País Basco O V realizou-se em Colónia (Setembro 1989): Lengua y Cultura en la Hispania Prerromana, Salamanca, 1993; o VI em Coimbra (Outubro 1994): La Hispania Prerromana, Salamanca, 1996; o VII em Saragoça (Março 1997): Pueblos, Lenguas y Escrituras en la Hispania Prerromana (Salamanca, 1999); o VIII em Salamanca (Maio 1999): Religión, Lengua y Cultura Prerromanas de Hispania (Salamanca, 2001); o IX em Barcelona (Outubro 2004): Palaeohispanica 5, 2005; realizou-se o X em Lisboa (Fevereiro 2009): Palaeohispanica 9, 2009.

${ }^{45}$ Cf., a título de exemplo, a sua dissertação de doutoramento Une Civilisation Protohistorique du Sud du Portugal (1er Age du Fer), Paris, 1986.

${ }^{46}$ Cf. A Epigrafia da Idade do Ferro do Sudoeste da Península Ibérica, Porto, 1996 (com exaustiva bibliografia).
} 
de la Espana Romana y Visigoda, de José Vives (Barcelona, 1969), continua, no entanto, a ser a obra mais actualizada como recolha, tendo Manuela Alves Dias e Catarina Gaspar preparado o corpus integral desses achados ${ }^{47}$, de que Mário

Barroca apresentou também, nos anexos do vol. III da sua tese (citada a seguir), um catálogo da epigrafia paleocristã portuguesa (século V a VIII) [p. 5-50] ${ }^{48}$.

Quanto à Epigrafia Medieval, a figura enorme de investigador incansável foi, sem dúvida, a de José Maria Cordeiro de Sousa, de que foi dada à estampa (Coimbra, 1983) a $4^{a}$ edição (já esgotada) dos seus preciosos Apontamentos de Epigrafia Portuguesa.

A Cordeiro de Sousa (1887-1968) se deve a leitura e a integração histórica das mais importantes das nossas inscrições. Exemplo a seguir, pois existem por esse Portugal além, dispersas por ermidas e monumentos, inúmeras pedras escritas, cujas mensagens - pedaços da história pátria, memória dos nossos antepassados - inexoravelmente se apagarão, se lhes não lançarmos mão a tempo. E quanta inscrição tumular não poderá trazer luz a momentos obscuros da nossa história!

A monumental tese de Mário Jorge Barroca, Epigrafia Medieval Portuguesa (862-1422), 3 volumes, Lisboa, 2000, veio colmatar, mui felizmente, essa lacuna em relação ao período indicado e Mário Barroca apresentou também, nos anexos do vol. III, o catálogo das inscrições muçulmanas e judaicas encontradas em território nacional (p. 52-94).

De facto, se, no domínio da Epigrafia Romana, Portugal está com a Europa há vários anos, passadas largas há que dar na preservação do nosso património epigráfico medieval e moderno. Tarefa que até nem é difícil e onde as associações de defesa do património local têm uma palavra a dizer.

\footnotetext{
47 DIAS (Maria Manuela Alves) e GASPAR (Catarina Isabel Sousa), Catálogo das Inscrições Paleocristãs do Território Português, Centro de Estudos Clássicos, Lisboa, 2006.

48 Para a epigrafia cristã de Mérida: RAMÍREZ SÁDABA (José Luis) y MATEOS CRUZ (Pedro), Catálogo de las Inscripciones Cristianas de Mérida. Cuadernos Emeritenses - 16. Mérida, 2000.
} 


\subsection{O ensino da Epigrafia}

O dinamismo actualmente pressentido no domínio da ciência epigráfica justifica mais umas breves linhas a servir de subsídio para a história do ensino da Epigrafia em Portugal, designadamente na Faculdade de Letras da Universidade de Coimbra ${ }^{49}$.

Já Abel Viana sentira a necessidade de fornecer, em pequena síntese, uma panorâmica dos núcleos epigráficos e da actividade dos epigrafistas até ao seu tempo (Arquivo de Beja 18-19 1961-62 108-113). E, de facto, ao folhearmos as páginas dos volumes da Bibliografia Arqueológica Portuguesa relativos a 195059 (Lisboa, 1973) e 1960-69 (Coimbra, 1970), é fácil apercebermo-nos da multiplicidade de artigos que, sobre Epigrafia ou com base na Epigrafia, se têm publicado entre nós, saídos da pena do Pe Eugénio Jalhay, de D. Domingos de Pinho Brandão, de Scarlat Lambrino, D. Fernando de Almeida, Fernando Bandeira Ferreira, Justino Mendes de Almeida, Mário Cardozo e outros, a que já aludimos atrás.

\subsubsection{O lugar da Epigrafia na Faculdade de Letras}

Foi José Leite de Vasconcelos quem, por primeiro, leccionou Epigrafia em Portugal. Dessa actividade docente nos dá conta n'O Archeologo Português (XV 1910 333-336). No ano lectivo de 1899-1900, por exemplo, a Epigrafia ocupou lugar dominante nas suas preocupações: as aulas foram dadas no Museu do Carmo e os sumários assinalam que se falou da importância da Epigrafia como fonte histórica, da língua dos textos, do material dos monumentos e dos vários tipos de inscrições. Em 1900-1901, dois temas principais: o exame do CIL II cujo autor, Emílio Hübner, falecido a 21 de Fevereiro de 1901, mereceu de Leite de Vasconcelos pormenorizada referência nas aulas - e as inscrições visigóticas.

\footnotetext{
49 Uma primeira e breve panorâmica, ainda que desactualizada, do ensino da Epigrafia em vários países pode consultar-se in Epigraphica 461984 263-265.
} 
Na Faculdade de Letras da Universidade de Coimbra, o lugar da cadeira de Epigrafia no plano dos estudos variou segundo as reformas, válidas também de resto para as demais Faculdades de Letras do País:

- Criada a Faculdade, pelo decreto de 19 de Agosto de 1911, e aprovados os seus cursos, a Epigrafia figura no curso de Ciências Históricas e Geográficas como uma das ciências auxiliares da História.

- Pela reforma de 1918, a Epigrafia manteve-se nesse curso, mas passou a ser uma cadeira do $3^{\text {o }}$ ano, trimestral, com quatro aulas semanais (duas teóricas e duas práticas), ministrada em conjunto com a Paleografia durante o primeiro semestre.

- Com a reforma de 1930, passa a semestral, com os mesmos tempos semanais, figurando no elenco das cadeiras obrigatórias dos cursos de Ciências Históricas e Filosóficas ( $1^{\circ}$ ano) e de Filologia Clássica ( $2^{\circ}$ ano).

- A reforma de 1957 poucas alterações introduziu: a Epigrafia permanece disciplina do $1^{\underline{0}}$ semestre, no $1^{\underline{o}}$ ano de Histórico-Filosóficas (reforma de 1930), mas passa a ser do $2^{\mathrm{o}}$ ano no novo Curso de História (agora autónomo) e do $3^{\circ}$ ano de Filologia Clássica.

- Com a reforma de 1968, a Epigrafia conhece um certo declínio: deixa de ser obrigatória em Filologia Clássica e é relegada para o $1^{\circ}$ semestre do $4^{\underline{0}}$ ano de História, mantendo ainda os mesmos quatro tempos semanais.

- Em 1975, quando a Faculdade pôde finalmente organizar o seu próprio plano curricular, criaram-se as pré-especializações de dois anos após o bacharelato (de três anos). A Epigrafia Latina recupera, nessa altura, o seu lugar: passa a anual e obrigatória na Pré-especialização em Arqueologia Clássica (do curso de História), mantendo-se opção para Filologia Clássica. Com essas características funciona, pela primeira vez, no ano lectivo de 1975-76.

- Em 1978, por força do decreto-lei no 53/78, de 31 de Maio, o plano de estudos da Faculdade voltou a ser alterado e a Epigrafia volta a simples cadeira de opção, semestral. Mas, como tal, apenas funcionou em 1979-80, paralelamente com a Epigrafia Latina (anual) da Pré-especialização (cujo 
currículo só caducou efectivamente no ano lectivo de 1980-81). No entanto, nesse mesmo ano de 1980-81, entrou em funcionamento na Faculdade a Variante em Arqueologia (criada pela portaria 268/81, de 13 de Março), em cujo currículo a Epigrafia, mantendo o seu carácter de disciplina anual, figura no segundo ano como optativa em relação à Numismática, aconselhando-se, porém, os alunos a fazerem uma e outra.

\subsubsection{Os professores}

Diversos professores garantiram a regência da cadeira. O primeiro foi António Garcia Ribeiro de Vasconcelos, desde 1912 a 1927. A dois investigadores ligados mais directamente à História de Portugal também foi pedida a colaboração: Damião Peres (de 1929 até presumivelmente 1934) e Torquato de Sousa Soares (de 1944 a 1947). O professor Joseph Piel, bem conhecido pelos seus trabalhos de Linguística, leccionou Epigrafia em dois períodos: de 1939 a 1941 e de 1947 a 1953. Ligada como está aos Estudos Clássicos, por duas vezes se pediu a docentes do Instituto de Estudos C1ássicos da Faculdade que se encarregassem da cadeira: Manuel de Oliveira Pulquério leccionou-a de 1959 a 1961 e Walter de Sousa Medeiros no ano lectivo de 1962-63.

Foi, porém, o pe Avelino de Jesus da Costa quem mais anos se manteve à frente da leccionação desta disciplina: desde 1953 a 1958 e desde 1963 até 1973. A ele se deve o primeiro manual português de Epigrafia, Apontamentos de Epigrafia (Coimbra, 1972); publicado sob a forma de sebenta para os estudantes, resume clara e eficazmente os dados fundamentais, não só no domínio da Epigrafia Latina mas também no que diz respeito às inscrições cristãs e medievais.

\subsubsection{As publicações}

Não foi a Epigrafia dos domínios mais procurados para a elaboração de teses de licenciatura. Contudo, algumas se fizeram então, na Faculdade de Letras da Universidade de Coimbra; citamos: 
- Maria de Lourdes Rodrigues, Antroponímia Romana da Lusitânia (1958);

- Maria de Lourdes Taborda Tavares, Subsídio para o Estudo dos Símbolos e Motivos Ornamentais das Estelas e Cipos Funerários Lusitano-romanos 58 (1964);

- Ana Maria Nascimento Coutinho, Subsídios para o Estudo dos Marcos Miliários em Portugal (1967);

- Ana Cândida da Silva, Subsídios para o Estudo da Epigrafia Romana em Portugal (1968).

Todas se encontram apenas dactilografadas.

A nossa entrada para o corpo docente da Faculdade, no ano lectivo de 1975-1976, coincidiu com o atrás referido renascer dos estudos epigráficos e logo no volume XV (1976) da revista Conimbriga, do Instituto de Arqueologia, temas de Epigrafia ocupam 7 dos 15 artigos publicados e metade das recensões bibliográficas. De então para cá, a Conimbriga é seguramente a revista portuguesa que mais espaço tem dedicado à Epigrafia. E do Ficheiro Epigráfico atingiu-se, em 2009, o no 89, com mais de 415 inscrições inéditas publicadas. 
A INSCRIÇÃO 
(Página deixada propositadamente em branco) 


\section{SUA GÉNESE}

Para o que se prende com a epigrafia romana, foi, sem dúvida, Giancarlo Susini quem - melhor que ninguém - soube explicitar os momentos por que passava a génese de uma epígrafe, na obra, hoje clássica, Il Lapicida Romano ${ }^{1}$.

"Lapicida" seria, literalmente, o que 'cortava a pedra'. Importa, porém, recordar que, se o seu trabalho principal se desenrolava numa oficina, havia previamente que obter o suporte, de acordo com a encomenda que lhe fora feita. Recorreria, habitualmente, ao seu fornecedor, o dono da pedreira mais próxima, a quem pediria que cortasse os blocos consoante as medidas adequadas. Havia, pois, primeiro, a acção do cabouqueiro; depois, o canteiro ajeitaria a pedra de forma a poder receber a inscrição. O canteiro operaria tanto na pedreira como na oficina do lapicida, porquanto the era exigido minucioso cuidado na feitura do monumento. Se não tivesse ajudantes, o dono da oficina faria o desenho de tudo e encarregar-se-ia ele próprio de fazer a gravação do texto.

Note-se, desde já, que, na elaboração do texto, não entra apenas a vontade do encomendante - que é soberana, sabe-se, mas pode ser adaptada às circunstâncias, aos modelos, às disponibilidades existentes, aos hábitos da própria oficina. Não é vulgar vermos, nos nossos cemitérios, que todas as campas - ou quase todas - obedecem ao mesmo 'figurino'? Certamente porque são fruto da mesma oficina.

\footnotetext{
${ }^{1}$ A $1^{\text {a }}$ edição data de Bolonha, 1966. Foi integrado no volume Epigraphica Dilapidata (Faenza, 1997), p. 7-69.
} 


\section{O CONCEITO DE "OFICINA EPIGRÁFICA"}

Definir-se-á, pois, oficina epigráfica como o local onde são executados monumentos epigráficos e ao epigrafista compete, tantos séculos volvidos, tentar identificar oficinas, através dos tiques comuns que monumentos da mesma área geográfica apresentam: o tipo de letra, a decoração, a forma do suporte, o material utilizado... Não há, evidentemente, monumentos iguais; há, porém semelhanças, identidades - os 'tiques' a que atrás nos referíamos - que deixam transparecer a existência de uma oficina; mas não uniformidade.

Por outro lado, importa dizê-lo, torna-se óbvio que uma oficina só se instala onde houver matéria-prima abundante e clientela suficiente. Não nos admira que, em Coimbra, em todos os tempos, desde a época romana, houvesse uma ou várias oficinas, mormente atendendo à proximidade das pedreiras de Ançã. Não há dúvida - porque até temos inscrições a demonstrá-lo - que o santuário ao deus indígena Endovélico, sito em Terena, Alandroal, possuía «ao seu serviço" lapicidas, não só porque são abundantíssimas as inscrições dedicadas a esta divindade, mas também porque nos situamos em plena zona de exploração dos melhores mármores alentejanos.

Um associação operária (collegium) de Filipos fazia saber aos clientes quais as suas especialidades. Na inscrição que haviam mandado pôr como publicidade $^{2}$, expressamente referiam: petram excidere, titulum facere, titulum polire, nomina inscribere, nomina scribere et sculpere. Ontem como hoje, as fases de preparação da epígrafe seriam as mesmas:

- petram excidere: cortar, na pedreira, o bloco apropriado (obra do cabouqueiro, já se disse);

- titulum facere: preparar o monumento às dimensões exigidas (trabalho do canteiro, como o será também a fase seguinte);

- titulum polire: afeiçoar o conjunto para se preparar o campo epigráfico, ou seja, o lugar onde a inscrição será inserida;

\footnotetext{
2 Trata-se da inscrição no 633 do vol. III do Corpus Inscriptionum Latinarum (= CIL).
} 
- nomina inscribere: fazer a paginação, isto é, estudar a melhor forma de gravar o texto no espaço disponível; esta operação seria, naturalmente, feita num 'rascunho' ou mesmo na própria pedra mas com 'carvão' ou 'giz' (diríamos hoje); uma operação que exige conhecimentos da escrita, da possível forma de abreviar ou pôr em siglas algumas palavras por de mais conhecidas, conhecimentos do objectivo que tem o cliente, pois se tornará necessário dar, porventura, um módulo maior a determinada palavra, para salientar a sua importância no conjunto;

- nomina scribere, "escrever as palavras": implica a passagem, quase em jeito de desenhador, do texto já pensado para a pedra, respeitando os espaços, colocando a pontuação, alinhando à esquerda, segundo um eixo de simetria ou à esquerda e à direita; é trabalho do lapicida, a que, certamente, muitos canteiros se dedicavam também;

- finalmente, nomina sculpere: a gravação.

Atente-se, pois, que o resultado final reflecte não apenas circunstancialismos de momento (disponibilidade do material, moda...) mas constitui, fundamentalmente, o cruzamento, digamos assim, da mentalidade do cliente com a mentalidade e o saber do lapicida. Como hoje, quando queremos pôr anúncio num jornal, temos uma ideia, podemos exigir que o texto saia tal e qual como o pensámos, mas amiúde - há uma conversa com um dos redactores ou com a pessoa que recebe o anúncio e já tem modelos e pode, na circunstância, aconselhar este ou aquele.

\section{OS ASPECTOS PALEOGRÁFICOS}

Falávamos de «modas». Nem sempre as letras se grafaram da mesma forma e isso sabem-no bem os paleógrafos, que, através da cuidada análise da escrita, são capazes de identificar inclusive o 'notário' que fez aquele documento na Idade Média ou nos tempos modernos, porque era assim que, em determinados períodos da História, se escrevia. 
No que concerne à escrita romana - e o conceito aplica-se também às escritas posteriores -, costumamos considerar três tipos de caracteres. Para já, importa salientar que, nas inscrições, as letras são geralmente capitais (maiúsculas). Recebem o nome de monumentais quadradas quando muito regulares, passíveis de serem inscritas num quadrado; actuárias, quando as hastes horizontais se apresentam levemente onduladas e a altura excede a largura; cursivas, quando se aproximam da maneira corrente de escrever à mão, sem serem em capitais (é o tipo de letra vulgar nos grafitos e nas tabulae ceratae, "tábuas enceradas" onde se escrevia com estilete).

Tal como acontece com os paleógrafos, também os epigrafistas usam os dados paleográficos para tentarem datar uma inscrição. Na verdade, importa recordá-lo, se uma inscrição é feita para todo o sempre, frequentemente se oculta a data em que foi feita, para ser um 'eterno presente'. A paleografia constituirá, pois, uma pista interessante para datação, ainda que apenas por séculos. Consciencializemo-nos, contudo, de que as modas vêm e vão, de modo que nunca se pode fazer uma datação peremptória, se não houver outros elementos complementares. Aliás, o epigrafista raramente escreve "esta inscrição é do século I"; prefere ser mais cauteloso: "Esta inscrição é datável do século I".

\section{OS ERROS COMO ELEMENTO CULTURAL}

Pode o operário ser analfabeto e não ter a menor ideia do que está a escrever. Segue a minuta que lhe apresentaram, tenta ser-lhe fiel, mas... nas dúvidas? O senhor não está por perto, o cliente, se calhar, também não sabe muito bem como é que as palavras se escrevem...

Na série de imagens, que recebemos, de vez em quando, através da internet, sob o título genérico "Portugal no seu melhor", a questão dos erros ortográficos é a mais recorrente. Um desses cartazes poderá ser bem exemplificativo do que se acaba de dizer: 


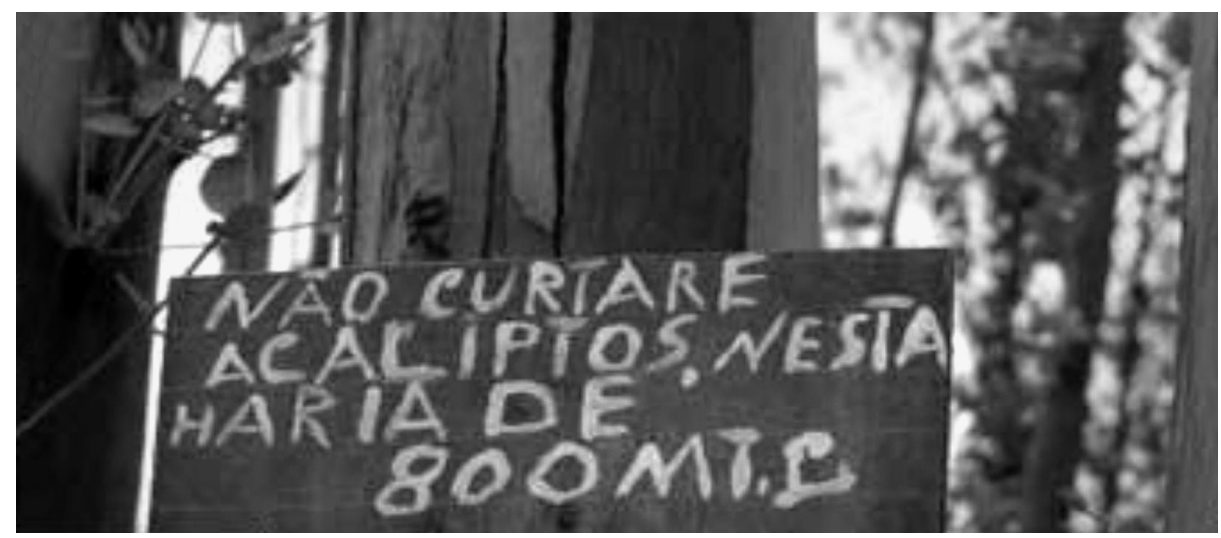

"NÃO CURTARE ACALIPTOS NESTA HARIA DE 800 MTS»...

No fundo, as pessoas acabam por escrever como lhes soa - e convenhamos que é bem mais complicado escrever:

«NÃO CORTAR EUCALIPTOS NESTA ÁREA DE 800 M»!...

Essa observação é muito válida no que concerne à aculturação entre romanos e indígenas, quando se trata de passar a escrito um nome indígena, que romano nunca ouviu, ou o teónimo que cada pessoa até é capaz de pronunciar à sua maneira: Endovellicus, Enobolicus, Indovellicus...

O erro, em Epigrafia, deixou, pois, de ser encarado como um sintoma de mero analfabetismo para se tornar um sintoma cultural que interessa investigar. Nesse aspecto, o caso da necrópole da villa romana da Quinta de Marim (Olhão) pode ser apresentado como significativo, pois que o suporte epigráfico obedece a regras estéticas clássicas (diríamos), enquanto a maioria dos textos não foi sequer entendida e, então, as siglas finais, que o paginador (ordinator) possivelmente apenas 'gatafunhou', por serem tão banais no quotidiano, não foram minimamente compreendidas pelo operário.

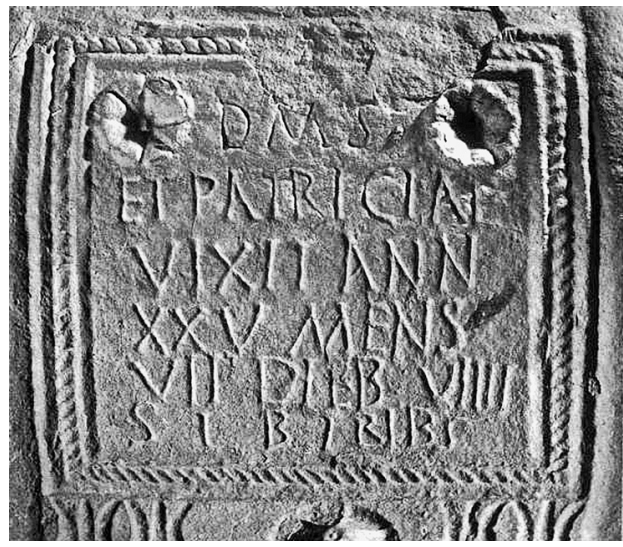




\subsection{As diversas linguagens}

66

Veicula o documento epigráfico um tipo específico de linguagem: a linguagem epigráfica.

$\mathrm{Na}$ verdade, ao lado de uma linguagem erudita, a que vem nos livros de literatura, cuidada, magnífica, à qual, de resto, apenas uma franja mínima da população teria acesso, há a linguagem do quotidiano, muito mais solta e espontânea, de que os autores teatrais aqui e além certamente não deixaram de se fazer eco. Aliás, não andaremos longe da verdade se afirmarmos que era o recurso a essa fraseologia e a esses termos do dia-a-dia que fariam as delícias dos espectadores, que os levariam a sentir como retrato da sua vida a ficção que lhes apresentavam - tal como, na actualidade, uma peça teatral ou uma telenovela detém mais êxito quanto melhor souber respirar realidade.

O texto epigráfico obedece a regras específicas, como os requerimentos no antigo papel selado, não se pode fugir muito ao esquema. Por isso se diz que há uma "linguagem epigráfica". Mas há que não esquecer que, por detrás do escrito lapidar, está o Homem e o seu universo. Há já formulários típicos nos nossos telemóveis para enviar mensagens diversas, com abreviaturas e siglas convencionais que estão a tornar-se usuais; contudo, nada impede que a minha saudação por ocasião de um aniversário ou o pedido de marcação de um encontro não seja original e não deixe de obedecer às mais elementares regras gramaticais ou ortográficas. E essa 'transgressão' detém um significado, que importa descobrir.

"Bigada migo adorei», telegráfica resposta em correio electrónico, tem muito por onde analisar e definitivamente não se compreenderá se não se estiver dentro do contexto. Precisamos de saber quem a enviou e porquê; precisamos, ainda e talvez por aí se devesse começar a nossa análise, de a decifrar, pois há duas palavras que fogem ao comum. Suspeitamos de um contexto de ternura, insinuado pelo termo "adorei», retirado do vocabulário religioso mas frequentemente aplicado na fala de todos os dias; contudo, desconheceremos sempre a causa dessa 'adoração' e tudo o que nela está implícito. Também ficamos curio- 
sos acerca da identificação dos dois interlocutores, ainda antes de descodificarmos as duas primeiras palavras. Se situarmos o texto no mundo juvenil, acharemos, quiçá, normal, se percebermos as palavras: «Obrigada, amigo! Adorei!». Se, porém, for num contexto adulto e de elevada craveira intelectual, o 'caso' muda de figura!...

\subsection{Exemplos contemporâneos}

Na verdade, embora a linguagem epigráfica seja fundamentalmente uma linguagem sintética, pensada, rigorosa, o certo é que o texto gravado resulta de uma minuta ditada ou copiada. Daí os "erros". Ainda hoje os podemos observar no nosso dia-a-dia e já certamente mais do que uma vez nos adregou interrogarmo-nos: porque não os corrigiram? Por ignorância, por distracção ou, simplesmente, porque a mensagem a transmitir não saía daí beliscada e não valia a pena - ou já não se podia - fazer novo monumento?

Esta questão dos "erros" em inscrições assume, por vezes, aspectos inusitados, que talvez não seja ocioso referir. Alguns testemunhos reais contemporâneos ajudar-nos-ão, sem dúvida, a melhor irmos ao cerne da questão, consciencializando-a por inteiro e despertando, por isso mesmo, o nosso interesse maior.

1. Num cemitério de Bragança, uma das placas funerárias ostenta o nome de TRESA (por TERESA), visível reflexo da fala quotidiana.

2. No painel dum restaurante dos arredores de Lisboa lia-se, até há pouco, SOLAR DOS FANGOS - e a falta do R (por mero lapso) começou a funcionar como factor publicitário.

3. A louça típica do Redondo trazia dizeres de cuja pintura normalmente se encarregavam as crianças da família. Daí resultavam frequentes erros ortográficos, uma garantia mais de que se tratava de louça pintada à mão e executada segundo técnicas tradicionais. O "fenómeno" tornou-se, porém, tão evidente e afamado que houve alguns oleiros adultos que, propositadamente, passaram a escrever com erros, numa de faz-de-conta... 
4. Uma das minhas antigas alunas, Mestre Lídia Fernandes, deparou, no cemitério da Guarda, com o seguinte epitáfio ${ }^{3}$, que não hesitou em fotografar e enviar-me:

naceu o 4 abril 1966

falceu o 31 julho 1986

SEBASTIAÕ FERNANDES

Ofrecida pelo o seu irmão fernando

Que dizer? Que mundo - para além da dor da perda de um ente querido ceifado na flor da idade - estará por detrás destas linhas? Que significado detêm, afinal, todos estes 'erros'?

E, mesmo que não embrenhado nas lides epigráficas, o passante minimamente culto não só não fará pouco do que vê (mal) escrito - que, aliás, o campo é santo e não permite risadas... - como de imediato se interrogará do porquê.

Reflexo de uma linguagem oral, não temos dúvidas. Fielmente transcrita para a placa por quem igualmente 'navega' no mesmo horizonte linguístico ou redigida assim porque o encomendante assim o exigiu, ainda que contra a vontade do artífice? Essa, a primeira questão, pois uma epígrafe (importa não o esquecer) resulta da intervenção do cliente e do gravador, denuncia a cultura dum e doutro.

Neste caso (e esta é a segunda questão), que significado atribuir a estes aparentes desvios de linguagem? E, para se responder (sem, obviamente, irmos saber, nos arquivos, quem é o Fernando, donde veio e o que faz...), conjecturamos um contexto: Guarda é terra de emigração para França; a forma como, aqui, a data vem indicada sugere nítida influência do falar francês; logo, estamos em presença duma família de emigrantes pouco cultos.

E se, como alguém me sugeriu depois, Sebastião Fernandes fosse de etnia cigana - que também os há e muitos no concelho da Guarda? Nesse caso, a aná-

\footnotetext{
3 Já atrás nos referimos a este caso, ainda que noutro contexto.
} 
lise partiria noutra direcção, noutro contexto linguístico, ainda que, nitidamente, a influência da oralidade seja, neste exemplo, um factor determinante.

\subsection{Duas cópias}

Vejamos duas cópias epigráficas dum mesmo texto romano, a fim de podermos verificar como ocorreu a intervenção do copista e a interferência da linguagem oral.

Mostram-se num dos pátios ajardinados do Museu Arqueológico Nacional, em Roma, dois marcos delimitatórios, da época republicana, que documentam uma importante terminatio, ou seja, a determinação dos limites, neste caso, verosimilmente, de um território público urbano.

O texto do primeiro diz o seguinte:

$\mathrm{P}($ ublius $) \cdot$ SERVEILIVS $\cdot \mathrm{C}($ aii $) \cdot[\mathrm{F}($ ilius $)]$

ISAVRICVS

$\mathrm{M}($ arcus $) \cdot$ VALERIVS $\cdot \mathrm{M}($ arci $) \cdot[\mathrm{F}($ ilius $)]$

$\operatorname{MAN}(i i) \cdot \mathrm{N}($ epos $) \cdot \operatorname{MESSAL}[\mathrm{A}]$

CENS(ores)

$\mathrm{EX} \cdot \mathrm{S}($ enatus $) \cdot \mathrm{C}($ onsulto $) \cdot \mathrm{TERMI}($ narunt $)$

É idêntico o texto do segundo:

$\mathrm{P}($ ublius $) \cdot$ SERVILIVS $\cdot \mathrm{C}($ aii $) \cdot \mathrm{F}($ ilius $)$

ISAVRICVS

$\mathrm{M}($ arcus $) \cdot$ VALERIVS $\cdot \mathrm{M}($ arci $) \cdot \mathrm{E}($ ilius $)$

$\operatorname{MAN}($ ii $) \cdot \mathrm{N}($ epos $) \cdot \operatorname{MESS}($ ala $) \cdot \operatorname{CENS}($ ores $)$

$\mathrm{EX} \cdot \mathrm{S}($ enatus $) \cdot \mathrm{C}($ onsulto $) \cdot \operatorname{TERMINAR}($ unt $)$

Trata-se, é bem de ver, do mesmo texto:

Públio Servílio Isáurico, filho de Gaio, Marco Valério Messala, filho de Marco, neto de Mânio, censores, por senatus-consulto delimitaram. 
As epígrafes terão sido feitas inclusive na mesma oficina, se atendermos ao ductus das letras e à sua forma.

No entanto, a ordinatio, ou seja, a paginação não foi a mesma (independen-

temente de, no primeiro monumento, faltarem alguns centímetros do lado direito). E, curiosamente, uma vez escreve-se SERVILIVS, outra SERVEILIVS à maneira arcaica (dir-se-ia); e o cognomen MESSALA tem mais ou menos letras escritas consoante o espaço disponível.

Houve, em ambos os casos, a preocupação de se paginar segundo uma lógica, "cortando" bem, de linha para linha, a identificação de cada um; contudo, no primeiro caso, quis acentuar-se o cargo exercido e, consequentemente, dar força e realce à autoridade que executava o acto jurídico-administrativo ditado pelo Senado e, no segundo, parece que "censores" é simples aposto.

Estamos, na verdade, perante um caso nítido em que a beleza do monumento, a composição do texto são de somenos; o que efectivamente interessa é o conteúdo, é testemunhar que o marco está ali - e não noutro lugar - porque houve uma autoridade que o determinou. E há que obedecer-lhe.

Poderemos deter-nos nesse mecanismo legal: o Senado ordenou; os censores executaram; a epígrafe publica e perpetua.

Atentar-se-á, finalmente, em mais dois pormenores:

1 - do segundo censor identifica-se o avô; é que os Valerii Messalae são célebres em Roma e há que não esquecer que este pertence à mesma estirpe; anote-se, de passagem, a grafia de E (por F) na linha 3 do segundo monumento, sintoma de que o lapicida não percebia muito bem o que estava a escrever...

2 - o texto ocupa somente a parte superior do campo epigráfico, o que é compreensível, porque, estando o marco cravado no chão, precisa de ser lido sensivelmente à altura dos olhos; não há, pois, uma paginação deficiente, como inadvertidamente se poderia afirmar, se não se tivesse em conta o lugar a que a epígrafe se destina. 


\subsection{Ouvir e escrever}

Discorreu largamente José Cardim Ribeiro ${ }^{4}$ sobre a ocorrência, na epigrafia romana de Sintra, do antropónimo Holumpus, em vez do clássico Olympos. Salientando que, mais uma vez, aqui a "oralidade local ou pessoal" se impôs, "Sobrepondo-se à correcção ortográfica", foi ainda mais longe, dando do facto uma significativa interpretação:

"Quem designou assim aqueles escravos - provavelmente o seu dominus - poucas ou quase nenhumas luzes tinha de grego, a língua culta, a língua da elite social de todo o Império; mas, sabendo-lhe o frequente uso de vogais aspiradas, designou e registou como Holumpus os seus escravos, para parecer mais grego, para parecer mais culto".

E conclui:

"Eis aqui como a escrita também pode evidenciar a oralidade afectada, como pode denunciar o preconceito cultural» (p. 95).

São inúmeros os casos em que a terminação - ae do dativo da $1^{1}$ a declinação latina surge, nas epígrafes, simplesmente grafada com um $e$ a denunciar a forma como, de facto, se pronunciava habitualmente. É quase constante a omissão do segundo $i$ no genitivo singular dos antropónimos: Fidi (em vez de Fidii), Fabi (em vez de Fabii), etc., mesmo em imponentes monumentos onde a ortografia seria de rigor. A explicação é simples: a crase dos dois ii era fenómeno tão corrente, na linguagem falada, que nenhum problema existia se tal assim ficasse escrito para a posteridade.

Um outro caso que, a princípio, perturbou os epigrafistas foi a 'alternância', em inscrições romanas, do $i$ e do $u$, nomeadamente na fórmula tão corrente: IOVI OPTIMO MAXIMO, que também aparece IOVI OPTVMO MAXVMO. Chegou a pensar-se em termos cronológicos, ou seja, que a forma em $u$ seria mais arcaica. Concluiu-se, depois, que as duas formas surgiam indistintamente,

\footnotetext{
${ }^{4}$ RIBEIRO (José Cardim), "Sons desenhados - letras sonantes. Escrita e oralidade na época romana", A Escrita das Escritas, Lisboa, Fundação Portuguesa das Comunicações, 2000, p. 87-96.
} 
sem obediência a quaisquer imperativos de tempo ou de lugar. Aliás, o mesmo acontecia com a grafia $x s$ ou $s$-Maxsimus, Maximus - cuja contemporaneidade se documentou, sem que motivo houvesse por uma ou outra opção. José Beleza Moreira estudou, por exemplo, dois epitáfios da Lourinhã, datáveis ambos da segunda metade do século II d. C.: num, a defunta designava-se Iulia Maxima; no outro, a dedicante foi Iulia Maxsuma 5 .

É natural, como sublinhou Manuela Alves Dias ${ }^{6}$, que a adopção de hábitos culturais e de modos de vida se processe mais rapidamente que a correcta entrada no quotidiano da expressão falada e escrita - como, hoje, nos é muito mais fácil vestirmo-nos à última moda de Paris do que falar fluentemente o francês. No entanto, o papel da linguagem oral e o entrosamento que ela provoca resultam, em todos os tempos, fundamentais.

\subsection{A teonímia}

Um dos domínios em que sobejamente se documenta essa relação entre a oralidade e a escrita é - ainda nas epígrafes romanas - o da teonímia indígena.

Tinham os indígenas os seus deuses; davam-lhes nomes, eventualmente relacionáveis com o atributo concreto que lhes era reconhecido. Chegaram os Romanos e perguntaram dos deuses, cientes de que os deviam respeitar, se queriam ter êxito político e social. Responderam-lhes os indígenas. Eram nomes estranhos, de sons pouco reconhecíveis para a fonética itálica, cantante e melodiosa. E, no momento em que foi necessário prestar-lhes culto, adregaram em escrever como lhes soava, a este duma maneira, àqueloutro duma outra... Não se importariam os deuses, não se ralariam os homens.

Até há pouco tempo, era Endovellicus a divindade nesse domínio mais sintomática: venerada que fora em S. Miguel da Mota (Terena, Alandroal), a ele

\footnotetext{
5 MOREIRA (José Beleza), "Duas inscrições funerárias romanas na igreja de S. Lourenço dos Francos", Conimbriga, XV, 1976, p. 127-131.

${ }^{6}$ DIAS (Maria Manuela Alves), "Da latinização onomástica à romanização onomástica no processo de aculturação dos Igaeditani, Symbolae Ludovico Mitxelena Septuagenario Oblatae quas edidit José L. MELENA, Vitória, 1985, p. 557-562.
} 
haviam sido feitas dedicatórias chamando-lhe (em dativo) Endovellico, Endovollico, Enobolico ${ }^{7}$. Achados recentes ${ }^{8}$ fizeram aumentar o número dessas variantes: Endoveleco, Ennovolico. Mas o certo é que, em santuários, o fenómeno começa a repetir-se e as descobertas da Primavera de 2003, na Galiza, mais concretamente no castro do Facho, onde se venerou a divindade Deo Lari Berobreoni ${ }^{9}$, vieram mostrar a grande diversidade de formas gráficas que o teónimo acabou por ter.

Toda esta problemática, aplicada aos textos latinos, foi superiormente enunciada por Giancarlo Susini ${ }^{10}$ e António Caballos Rufino exemplificou-a com muita acuidade, ao comparar as seis cópias do senatus-consulto de Gneu Cipião Pai, datado de 10 de Dezembro do ano $20^{11}$.

Concluindo: há, na verdade, nítidos erros ortográficos nas inscrições, resultantes de uma distracção momentânea, da leitura apressada da minuta ou mesmo da sua deficiente interpretação. Mas tudo isso constitui, para o epigrafista, nova fonte de informação, pois se procurará ajuizar da causa desse "deslize». Outros casos há, porém, em que divergências gráficas não se podem levar à conta de erros: são contaminações de uma linguagem oral, porque um ou outro dos intervenientes se não encontra totalmente dentro do contexto.

7 Cf. ENCARNAÇÃO (José d'), Inscrições Romanas do Conventus Pacensis, Coimbra, 1984, p. 800-805; RIBEIRO (José Cardim), "Endovellicus”, Religiões da Lusitânia, Lisboa, Museu Nacional de Arqueologia, 2002, p. 71-90.

8 GUERRA (Amílcar), SCHATTNER (Thomas), FABIÃO (Carlos) e ALMEIDA (Rui), "Novas investigações no santuário de Endovélico (S. Miguel da Mota, Alandroal): a campanha de 2002", Revista Portuguesa de Arqueologia, vol. 6 no 2, 2003, p. 415-479.

9 Cf., a título de exemplo, a informação veiculada por Joaquin L. Gómez-Pantoja através da archport@list-serv.ci.uc.pt, a 25 de Maio: “El periodico "La Voz de Galicia” (www.lavozdegalicia.es) en su edición de ayer (24.05.03) informa del hallazgo de sesenta altares con inscripción en el castro de Facho (Donón, parroquía de Hío, Cangas de Morrazo, Pontevedra) durante las excavaciones del lugar realizadas por Th. Schattner, del DAI de Madrid. Desde mediados de los años sesenta se habían encontrado en ese mismo sitio unos cuarenta altares dedicados a una divinidad llamada Berobronis o Breobrus, acompañada a veces de los epítetos Deus Lar (G. Baños, Corpus de Inscricións Romanas de Galicia, II, Pontevedra, Santiago 1994, 1-35 = AE 1994, 942-953 = HEp 6, 712-736).

${ }^{10}$ Cf. Epigraphica Dilapidata (Scritti scelti di Giancarlo SUSINI), n 15 da série "Epigrafia e Antichità", Faenza, 1997, p. 15-19.

11 "Las enseñanzas del S. C. de Cn. Pisone Patre. El método comparativo y la génesis del documento", Classica, Lisboa, 20, Dezembro 1994, p. 233-253. 


\section{ALGUNS TERMOS TÉCNICOS}

Neste domínio da inscrição propriamente dita, há, pois, alguns termos técnicos que importa recordar, em jeito de recapitulação:

Anepígrafo: monumento destinado a ter inscrição, mas que actualmente a não tem, ou porque ela nunca foi gravada, ou porque desapareceu. São importantes para rastrear hábitos tipológicos de oficinas epigráficas.

Campo epigráfico: superfície (preparada ou não) onde se gravou o texto.

Ductus: palavra latina que exprime o modo como as letras são traçadas. O estudo do ductus permite detectar cópias ou acrescentamentos posteriores.

Epígrafe: o mesmo que inscrição. Utiliza-se para designar o texto propriamente dito ou o monumento epigráfico no seu conjunto.

Lapicida: etimologicamente, o que corta a pedra. Designa o operário que grava o texto.

Linhas auxiliares ou de pauta: linhas traçadas previamente no campo epigráfico para regular a altura das letras e obter melhor efeito estético. Por vezes, 'sente-se' apenas a presença dessas linhas, embora elas tenham desaparecido; doutras, elas existem, muito ténues; doutras ainda, mantêm-se ostensivamente com finalidade decorativa.

Oficina epigráfica: local donde saíram monumentos epigráficos semelhantes na tipologia, no material utilizado, no modo de gravação e no formulário.

Ordinator (paginador): operário encarregado de fazer a distribuição do texto no espaço epigráfico (ordinatio, paginação). É natural que, na maior parte das oficinas, o paginador fosse pessoa diversa do lapicida, que se limitaria a gravar o texto conforme modelo apresentado pelo paginador. A paginação pode ser feita segundo um eixo de simetria, ou com alinhamento à esquerda ou à direita; quando há alinhamento simultâneo à esquerda e à direita, diz-se que se obteve uma "caixa".

Paleografia: ciência que estuda a evolução cronológica do traçado dos caracteres. Os dados paleográficos ajudam-nos a atribuir uma data às inscrições. 
Pontuação: usa-se para separar palavras; por isso, salvo para efeitos de paginação, não se coloca no fim das linhas. Pode também separar sílabas (interpunctio syllabica). Nas inscrições romanas, era obrigatoriamente posta a meio da altura das letras. Os puncti distinguentes podem ser redondos ou triangulares; por vezes, desenham-se folhas de hera (hederae distinguentes).

Sigla: forma de escrever uma palavra apenas pela sua letra inicial. Distingue-se da abreviatura, constituída por mais do que uma letra.

Tabula ansata: campo epigráfico rectangular com duas ansas laterais. É um modelo clássico.

Tabula cerata: à letra, "tabuinha encerada", em que se escrevia com estilete, em caracteres cursivos. No tempo dos Romanos, contêm, geralmente, actos jurídicos entre particulares. 
(Página deixada propositadamente em branco) 
INTRODUÇÃO AO ESTUDO DA EPIGRAFIA ROMANA 
(Página deixada propositadamente em branco) 


\section{O MODO DE IDENTIFICAÇÃO}

Se, como atrás se dizia, na esteira arguta e feliz de Gabriel Sanders, a missão primordial do monumento epigráfico é "sauver le nom de l'oubli", libertar o nome das garras do esquecimento, importa que saibamos o significado dos nomes e como é que as pessoas se identificavam. Se para todas as épocas isso é importante - não foi por mero acaso que Angelo Giuseppe Roncalli escolheu João para seu nome de Papa (João XXIII) - é-o, com mais forte razão, para a época romana, pois, a maior parte das vezes, apenas o nome temos de alguém e nada mais.

Tudo isto nos prova à saciedade a importância que, na verdade, tem o estudo do nome romano e, acima de tudo, a forma como ele vem escrito nas epígrafes, porque são mensagem pensada, para o futuro, conscientemente.

Importa, pois, saber como, pela forma como se identifica, se pode reconhecer o cidadão romano, o indígena, o escravo e o liberto e - porque não? - qual a nomenclatura usada pelos imperadores e, também, qual a carreira habitual (cursus honorum) dos senadores, dos cavaleiros e dos membros do que poderíamos chamar a "burguesia" municipal.

\subsection{A importância do nome}

O nome constitui, de facto, elemento fundamental numa epígrafe romana. Identifica-se o defunto; refere-se o dedicante dum altar votivo; explicitam-se miudamente nomes e funções do homenageado em texto honorífico; destaca-se quem mandou edificar aquele monumento, a expensas suas (ex pecunia sua) ou por ordem dos decuriões (decreto decurionum). 
Saber a identificação de alguém é, ainda hoje, passar a ter sobre esse alguém um certo poder. E vice-versa. Daí, os telefonemas anónimos, o anonimato de certas cartas...

Por outro lado, nem sempre a identificação obedece às mesmas regras. Varia segundo o ambiente, as funções, a... intimidade. Por isso, ontem como hoje, o modo de identificação denuncia o estatuto social, permite que sorrateiramente

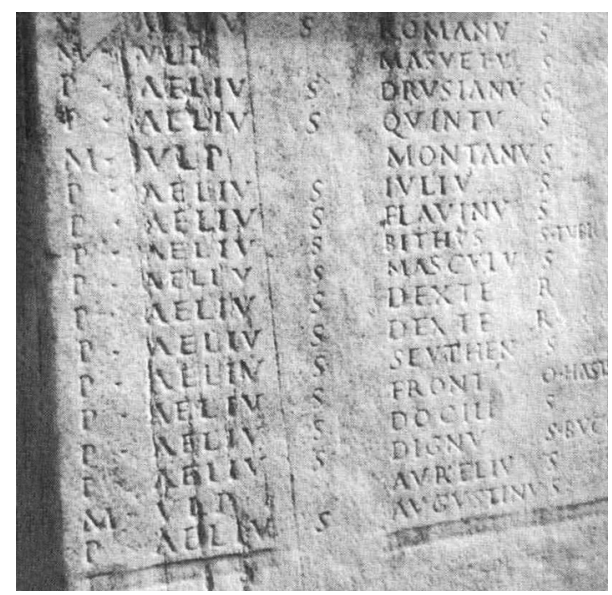
nos embrenhemos em convívio...

Ao tempo dos Romanos, havia regras, é evidente. Sobretudo para os documentos oficiais, como na actualidade, mais não fosse que por motivos estéticos: uma lista de nomes, como a que a fotografia apresenta, obedece claramente a ditames de paginação, que de outro modo se não entenderia o estranho alinhamento da letra final.

Já agora, talvez seja interessante atentarmos um pouco nesse monumento, de que se mostra um pormenor da face lateral. Trata-se de um altar a Júpiter Óptimo Máximo, exposto no Museu Arqueológico Nacional de Roma, mandado erigir por um grupo de soldados no momento em que passaram à disponibilidade, em que tiveram a honesta missio.

Esses veteranos identificam-se apenas pelos três nomes (tria nomina), acrescentando, porém, um ou outro a função que exerceram na legião: P(ublius) Aelius Bithus foi TVBIC(en), tocador de trombeta; P(ublius) Aelius Fronto, HAST(atus), lanceiro; P(ublius) Aelius Dignus, BVC(inator), corneteiro.

E se é compreensível a distracção da grafia com dois ss de Bithus, admirará, decerto, a circunstância de muitos componentes da lista se chamarem P(ublii) Aelii. A explicação é simples: a passagem à disponibilidade, serviço militar cumprido, abre-lhes a porta da cidadania romana; o imperador reinante tem, nesse domínio, o papel preponderante, porque é da sua autoridade - superiormente consubstanciada na auctoritas e no imperium - que dimana poder tão rele- 
vante. E o soldado, agora cidadão, assume na sua onomástica a intervenção imperial: passa a identificar-se como ele. Assim, os P. Aelii devem a cidadania a P. Aelius Hadrianus, o imperador Adriano; enquanto que os M(arci) Vlpii (há dois neste rol) tiveram particular intervenção de Trajano, que se chamava, antes de ser imperador, M. Vlpius Traianus.

E num texto funerário há a identificação do dedicante? A que propósito? Não bastaria, como nos nossos dias, escrever "eterna saudade do marido" ou da mulher, filhos e netos? Não. É que também aí entra o "salvar o nome do esquecimento". Quem garante ao dedicante que, anos mais tarde, alguém vai lembrar-se de imorredoiramente perpetuar na pedra o seu nome, tanto mais que há fortes probabilidades de o mesmo sepulcro ser o seu? Prefere, pois, não deixar a outrem uma tarefa que, sem dar nas vistas, ele pode muito bem fazer. Até porque - diga-se de passagem - assim se cumpre igualmente uma outra função social: lembrar à comunidade que foi ele quem mandou erigir o epitáfio.

Numa inscrição votiva, a humildade perante o deus há que preservar-se. Uma identificação mínima, só para se distinguir dos outros mortais, sem alardes, que a divindade não apreciará toleimas... Mas isso não impede que, uma vez por outra, o próprio nome se anteponha ao teónimo, antes que, numa série de ex-votos iguais, o seu se não distinga!...

Quem manda erguer um edifício é já suficientemente conhecido pelo seu estatuto político, social e económico, para que necessite de grandes alardes. Desta sorte, a inscrição monumental há-de ser singela, apesar do relevo que obrigatoriamente detém no seu suporte arquitectónico.

Casos há, porém, em que a identificação se esconde sob simples alusão: uxor, coniux, amicus... E damo-nos, então, bisbilhoteiros do séc. XX, a imaginar intimidades outras de que se suspeita, que apenas um delicado véu deixa antever... E as inscrições funerárias, como Marcel Durry bem assinalou ${ }^{1}$, têm destas inconfidências.

1 DURRY (Marcel), "Réabilitation des funerariae", Revue Archéologique, 1, 1961, 11-21. 
Justificar-se-á, portanto, que nos debrucemos mais em pormenor sobre os elementos de identificação dos cidadãos romanos, dos indígenas, dos escravos e dos libertos. Pelos nomes os vamos conhecer! E atentaremos no significado último do praenomen, do nomen, do cognomen, da filiação e da menção da tribo.

\subsection{O praenomen}

Como a própria palavra sugere, praenomen significa o que precede o nomen. É o primeiro elemento do nome romano. E, a princípio, o que, numa família, distingue dos demais o indivíduo do sexo masculino; daí que houvesse o hábito de ele ser diferente para cada um dos filhos varões e distinto do do pai. As mulheres não usavam praenomen: integradas numa família, parece que tal ausência se poderá interpretar como vontade de elas se não individualizarem, de se afirmar que só no seio da família a mulher gozava da prerrogativa de ser nomeada.

Na sua qualidade de elemento distintivo, o praenomen começou, pois, por deter um significado concreto: Tiberius, o que nasceu junto ao rio Tibre; Lucius, o que nasceu ao romper d'alva; Manius, o que veio à luz pela manhã; Spurius, o filho ilegítimo, espúrio; Gaius, o que veio dar contentamento; Martius, o que Março trouxe... Nas famílias numerosas - ou cujos pais pensavam desde logo em possuir grande prole - não é rara a existência de praenomina a indicarem a ordem de nascimento: Primus, Quintus, Sextus, Decimus...

Segundo Varrão, chegaram a ser trinta os praenomina usados; no entanto, são dezoito os mais correntes. Daí que, nas inscrições, raramente surjam por extenso, mas em sigla, porquanto toda a gente sabia o seu significado - como hoje, nas listas telefónicas, $\mathrm{A}^{\mathrm{o}}$ (António), $\mathrm{M}^{\mathrm{el}}$ (Manuel), Mª (Maria)... Só quando assume a toga viril, aos dezassete anos, é que o jovem tem direito a usar oficialmente o praenomen. Se falecer antes, pode inscrever-se no seu epitáfio a palavra Pupus, em lugar do praenomen, com o significado de "menino"; contudo, o mais normal é os pais escreverem, de facto, na pedra o praenomen que já tinham intenção de vir a atribuir-lhe ao chegar à idade adulta. 
Aliás, há praenomina típicos de cada família; ou seja, é normal o pai dar o seu praenomen aos filhos - como, aliás, também entre nós, e sobretudo no Brasil, se costumava fazer e, daí, acrescentar-se "Júnior", "Filho", "Neto". A afirmação está correcta porque os testemunhos mais abundantes, com que geralmente lidamos no território peninsular (e não só), datam do Império, ou seja, de um período em que o cognomen já havia sido introduzido. Por isso, numa análise de tipo demográfico, interessa-nos o nome de família, sim, mas também o prenome que lhe está associado: a coincidência de gentilício e de prenome numa área geográfica determinada oferece-nos sérias probabilidades de estarmos perante membros da mesma família.

Atendendo ao seu escasso valor identificativo, o uso do praenomen, inclusive em inscrições, vai desaparecendo aos poucos a partir de meados do século III da nossa era, até porque, como é sabido, desde o Édito de Caracala (212) que todo o homem livre do Império gozava dos direitos de cidadania. Antes, o praenomen funcionava como índice de um certo estatuto político-social não despiciendo; doravante, não. E passou a omitir-se. Terminemos com duas singularidades:

- em certas famílias destacadas, havia mulheres que oficialmente usavam praenomen: é sinal de privilégio só a algumas (raras) reservado;

- no momento em que os Romanos contactam as sociedades indígenas, ocorre a imitação, por parte destas últimas, do modo de identificação latino; e não é raro encontrarmos, como nomes únicos de indígenas, escritos por extenso, alguns praenomina, mormente os que detêm significado concreto facilmente compreensível: Gaius, Lucius, Primus, Sextus...

\subsection{O nomen}

Ao nomen se chama também gentilício, por ser o nome da gens - a família - a que determinado indivíduo pertencia.

Habitualmente terminado em -ius, para o masculino e -ia, para identificar os elementos do sexo feminino, o gentilício integrava o nome de todos os componentes de uma mesma família: os homens, as mulheres, os libertos e as libertas. 
Mas, também aqui, há que reflectir. Tal como todos os Rodrigues existentes numa cidade não pertencem, necessariamente, à mesma família, assim terá acontecido em Roma e nas cidades do Império: nem todos os Iulii ou Caecilii documentados nas inscrições de Olisipo, por exemplo, pertencem, obrigatoriamente, à mesma família.

E será que teremos, hoje, critérios que nos permitam algumas certezas?

Antes de mais, se os textos provêm da mesma zona e são datáveis da mesma época (informação passível de nos ser dada pela semelhança na tipologia dos monumentos e/ou da paleografia), pode muito bem acontecer que não estejamos longe da verdade se optarmos por os considerar a todos da mesma família.

No entanto, um dos critérios de maior verosimilhança prende-se, como atrás se disse, com a ocorrência simultânea do gentilício acompanhado do mesmo praenomen. Como, a partir do Império, havia, na família, o hábito de o praenomen ter um carácter quase definitivo e definidor, que se transmitia de pais para filhos, os C(aii) Iulii de Olisipo correm sério risco de pertencer todos ao mesmo ramo de uma gens Iulia que ali se estabeleceu, em dado momento, quiçá logo no princípio do Império, enquanto que os T(iti) Iulii serão, quase de certeza, um ramo diferente dessa família.

E tal circunstância pode oferecer-nos igualmente um índice cronológico. É que, na verdade, também a adopção, mormente por parte dos indígenas romanizados, de uma onomástica latina, se prende com a moda, ligada amiúde ao imperador que reina no momento em que assumem a cidadania ou o estatuto de peregrini. É por esse motivo que nós pensamos que os Tiberii Claudii epigraficamente registados são do tempo do imperador Cláudio, verosimilmente; que os Titi Flavii são contemporâneos dos Flávios (69-96), que os Publii Aelii viveram ao tempo de Adriano, imperador que se chamava P. Aelius Hadrianus. E assim por diante.

Geralmente, identificam-se com gentilício pessoas que já estão bem enquadradas na estrutura social romana. Mas há também casos curiosos, que deixam transparecer, por parte de indígenas, uma aculturação incipiente, por exemplo quando usam nomina que são praticamente latinizações de nomes indígenas. Estou a lem- 
brar-me de Sagaius, que não aparece no rol dos gentilícios latinos e que, numa inscrição do Sudoeste alentejano (FE 82), exerce funções claras de gentilício.

O nomen transmite-se de pais para filhos, por linha paterna. E se, numa inscrição, o filho detém o gentilício da mãe? Nesse caso, são prováveis duas hipóteses: ou se trata de um filho ilegítimo ou a mãe é uma liberta e o filho foi libertado ao mesmo tempo que ela, recebendo ambos o mesmo gentilício, por estarem incorporados na mesma gens.

E se a mulher tem o mesmo nomen do marido, o que denotaria, em rigor, a pertença a uma mesma família, contrariando, assim, as leis do connubium romano? Nessa circunstância, é bem provável que se trate de um casal de escravos que o patronus libertou (casal não no sentido jurídico, entenda-se, mas no sentido real) e a quem, no acto da libertação, outorgou, como era hábito, o seu próprio gentilício.

Ora aqui está como, partindo de aspectos à primeira vista de somenos, acabamos por penetrar, mesmo sem querer, num quotidiano vivo de que os livros - os outros livros, que não os de pedra - não deixaram qualquer vestígio.

\subsection{O cognomen}

\subsubsection{Em contexto latino}

A partir do momento em que o praenomen e o nomen já não constituíam identificação bastante, tornou-se necessário acrescentar um elemento ao nome, para que a distinção ocorresse. E esse elemento foi o cognomen. Entre nós, na actualidade, deu-se um outro fenómeno, igualmente curioso: como Marias, Manéis, Antónios havia muitos e eram nomes populares, optou-se por se lhes ajuntar um outro (que era, de resto, bastas vezes, aquele que ficava no quotidiano): Maria Manuela, Maria Antónia, Manuel Joaquim, António Manuel, Sara Patrícia... Nós optámos por mais um primeiro; os Romanos preferiram acrescentar um no fim e, dessa sorte, já poderiam manter o mesmo praenomen para todos os elementos masculinos da família. 
Vestígio dessa introdução "tardia" do cognomen é o facto de, na identificação por exemplo, de um cidadão romano, os cinco elementos identificativos virem na seguinte ordem: praenomen, nomen, filiação, tribo, cognomen. Assim, se encontramos na Península Ibérica uma inscrição em que um personagem não detém cognomen, podemos quase garantir com absoluta certeza de que estamos perante documento de finais da República ou primeiros anos do Império.

E voltamos ao esquema mental que ocorrera aquando da atribuição do praenomen: um critério objectivo, concreto. Era o primeiro filho? Chamava-se-lhe Primus. Seria, certamente, o mais velho de vários que se desejava ter? Dava-se-lhe o nome de Avitus. Fora ansiosamente esperado ou a gravidez decorrera com alguns problemas? Era Desideratus, Optata, Expectatus...

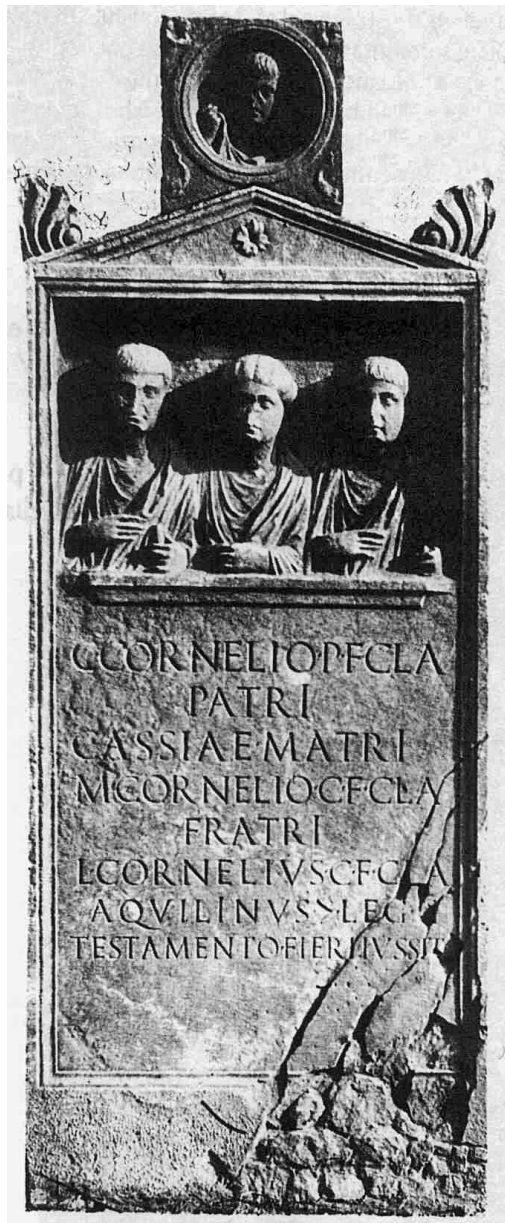

Neste domínio dos significados primeiros dos cognomes, a obra clássica é, ainda, a de Iiro Kajanto, The Latin Cognomina, publicada em Helsínquia em 1965, mas de que se fez reimpressão, em Roma (1982).

O texto da seguinte inscrição precisamente de Roma pode servir perfeitamente de exemplo para o que acabamos de dizer:

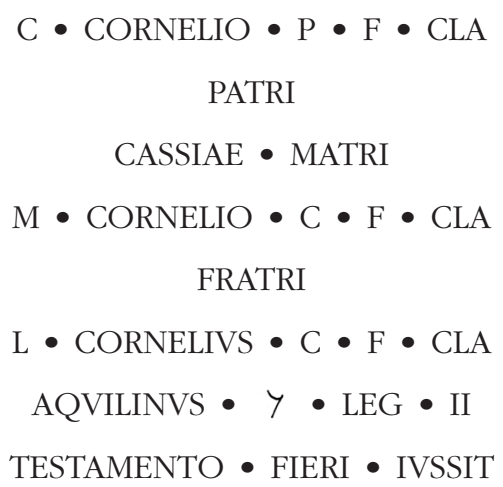

Por disposição testamentária (testamento fieri iussit), o centurião (isso significa o C invertido da penúltima linha) Lúcio Cornélio 
Aquilino, filho de Gaio, da tribo Cláudia, manda erigir monumento funerário a seu pai, Gaio Cornélio, à mãe, Cássia, e ao irmão, Marco Cornélio.

O texto data-se, pois, dos primórdios do século I da nossa era. Na verdade, verifica-se a total disparidade de praenomina: o avô é Públio; o pai, Gaio; o primeiro filho, Marco; e o segundo, Lúcio. Mas se pai, mãe e filho primogénito não apresentam cognomen, tal já não acontece com o dedicante, que se designa Aquilinus. E a escolha é deveras significativa, porque Aquilinus deriva de aquila, a "águia", símbolo das legiões, e Aquilino servia, como centurião, na II.

A atribuição de um cognomen tem aqui, também, um outro significado, que interessa desde já realçar. Lúcio ingressou no exército; o seu nome passou a constar de listas oficiais; e, nessas listas, pelo que conhecemos das que chegaram até nós, os escribas faziam questão em alinhar cada um dos elementos do nome, para melhor distinção. Assim, é de supor que, neste caso específico, mesmo que os pais lhe não tivessem dado um cognomen, Marco o houvesse adoptado por razões de... serviço!

Compreender-se-á, pelo que fica dito, que à análise etimológica do cognomen dediquem os epigrafistas e os linguistas importância fundamental, devido, principalmente, a este seu carácter concreto. Ele se perderá depois, bem entendido. No entanto, há hábitos culturais que perduram e isso é extremamente relevante do ponto de vista histórico.

Primeiro, porque não é indiferente a escolha de um nome grego, latino ou de raiz pré-latina; depois, porque a maior ou menor ocorrência de um nome em determinada área geográfica possibilitará significativas conclusões.

Certamente, teremos ensejo de voltar a este tema, tão rico de informação ele se apresenta, até pela comparação que vai permitir com o que ocorre na actualidade em relação a certos "estranhos" apelidos. Não deixaria, porém, de focar, desde já, dois aspectos para reflexão:

1. Quando se dá a aculturação, o encontro entre Romanos e povos préromanos, cada qual tinha, obviamente, a sua antroponímia. Por enquanto, é só nas inscrições feitas já à maneira latina que esses nomes aparecem. E quais são os nomes latinos que os indígenas primeiro adoptam? 
Precisamente os que se prendem com o quotidiano: a menina é um "amor", uma "ternura"? Chama-se-lhe Amoena. O rapaz saiu um tamanhão? Será Maximus!

2. E quando se trata de dar nome a escravo ou escrava? Quem não gosta de ter "coisa" com nome bonito? E escravo cujo dono se preze não é escravo da zona oriental do Império, alto, elegante, espadaúdo... como um deus descido do Olimpo?... Pois, mesmo que daí não seja, não faz mal, prantese-lhe nome a condizer: Hermes, Narcisus, Nymphe, Diodora... Dir-se-á que escravo só tem um nome e que, por conseguinte, é despropositado falar de cognomen neste caso. Ora aí está uma boa razão para, mais adiante, voltarmos a este tema.

\subsubsection{Em contexto indigena}

Já vimos que, nas inscrições - e repita-se que esses documentos já datam da época romana e pouco temos, por enquanto, que nos esclareça quanto aos nomes usados pelos povos pré-romanos peninsulares - os indígenas começam por identificar-se com um nome apenas. Não admira, dado que pequena é a comunidade e, se dúvidas houver, lá estará o patronímico a marcar a individualização: Reburrus Malgeini, por exemplo, o "Reburro de Malgeino".

Poder-se-á dar a este nome único a categoria de cognomen?

Perdoar-me-ão os peritos se tomo a questão por 'académica', ou seja, sem relevante interesse prático.

Na verdade, poderá parecer, à primeira vista, que cognomen só terá sentido se houver, pelo menos, o nomen. Creio que não. E não hesitarei, até convincente prova em contrário, na sua inclusão nessa categoria.

De facto, quando, no avanço da aculturação, se documenta a identificação com mais do que um nome (dois para as mulheres e três para os homens), o nome indígena vai ocupar precisamente o lugar do cognomen: T. Flavius Reburrus acompanha L. Annius Vitalis e mais cinco colegas, todos de onomástica latina, na homenagem feita, nos primórdios já do século II da nossa era, ao 
speculator da VII Legião Gemina Felix, Q. Annius Aper, que falecera sem deixar testamento (intestato defunctus).

Detêm, como facilmente se depreende, o maior interesse estes nomes etimologicamente pré-romanos e sobre eles se têm debruçado os linguistas.

A razão é simples: constituindo latinizações de sons usados no quotidiano, em que, portanto, a oralidade predomina, uma pesquisa atenta poderá permitir chegar não só ao primitivo significado concreto do nome como - o que é ainda mais importante - ao estrato linguístico a que pertence. Desse «estrato linguístico" ao povo que o falava ia um passo! Através da distribuição desses antropónimos, concretamente no espaço peninsular, se determinariam as várias levas de invasores/colonizadores, ou, dizendo doutra forma, a sua... "filiação genética»!

Explicitemos, em traços muito gerais.

Tem-se partido do princípio de que as línguas ocidentais derivam de um substrato linguístico comum a que se convencionou chamar o "indo-europeu". Nesse âmbito, a primeira grande obra de referência (ainda 'clássica') é a de Jürgen Untermann: Elementos de un Atlas Antroponimico de la Hispania Antigua (Madrid, 1965).

No entanto, se, até há uns tempos atrás - nomeadamente por via da 'escola alemã' (e compreender-se-á porquê...) - a quase totalidade dos nomes pré-romanos atestados na Península Ibérica radicavam no "celta" da Europa Central, hoje - que as autonomias ressurgem... - o ibérico, o celtibérico, o vasconço... começaram a ter também uma palavra a dizer. Daí que um dos últimos livros de Francisco Villar, outro dos especialistas que se tem vindo a dedicar a estes estudos e que superintendeu à publicação dos regulares colóquios sobre línguas e culturas paleo-hispânicas, sintomaticamente traga o título de Indoeuropeos y no Indoeuropeos en la Hispania Prerromana (Ediciones Universidad, Salamanca, 2000).

Trata-se, como se compreenderá, de um domínio que exige alguma especialização. Entre nós, o grande mestre ainda será José Leite de Vasconcelos, tendo Amílcar Guerra, da Faculdade de Letras de Lisboa, defendido, em 1998, justamente sob orientação de Untermann, tese de doutoramento, inédita, intitulada Nomes Pré-romanos de Povos e Lugares do Ocidente Peninsular. 
Reburrus, por exemplo, tem sido unanimemente considerado "nitidamente hispânicon:

"Os achados extrapeninsulares", escreve María de Lourdes Albertos, "Correspondem a pessoas de origem hispânica, por vezes soldados, e por diversas vezes isso mesmo se atesta claramente na correspondente inscrição".

Houve até um autor, José Rubio Alija, que escreveu substancial artigo a que chamou «Españoles por los caminos del Império romano. Estudios epigráficoonomásticos em torno a Reburrus y Reburrinus" ${ }^{2}$.

E se, num primeiro olhar, o antropónimo se deveria fazer derivar do adjectivo do latim tardio reburrus, "O rebelde", o "de cabelo eriçado", tal hipótese tem de pôr-se de parte, porque, como se acaba de referir, é palavra só existente no latim tardio, quando o termo surge em inscrições dos começos do Império; também não se pode entender como formado a partir de -burrus, pois existem outros antropónimos passíveis de atribuir-se ao mesmo radical, sendo -urrus considerado um sufixo. E se Alfredo Holder, outro alemão, que fez um dicionário dos antropónimos derivado do antigo céltico, o integra, sem mais, nesse rol, houve logo quem começasse a "desconfiar do seu celtismo" (para usarmos, mais uma vez, duma expressão de Lourdes Albertos); contudo, ao fazer o rol da onomástica romana peninsular, Juan Manuel Abascal Palazón ${ }^{3}$, parece dar a entender, afinal, que Reburrus é "nome latino de boa aceitação entre os indígenas" (p. 33).

Como se vê pela amostra, trata-se de um domínio assaz melindroso do ponto de vista científico, pois os elementos com que lidamos são passíveis de interpretações diversas e nem a recente descoberta, em Botorrita, de mais um bronze com inscrição em celtibérico, pôde dirimir todas as dúvidas ${ }^{4}$.

Um testemunho mais: Maelo - nome, por exemplo, de um conhecido oleiro de Conimbriga. Poder-se-ia aparentá-lo com o gentilício bem latino Maelius. Todavia, uma vez que predominantemente se documenta na Lusitânia, é voz

\footnotetext{
2 In Cuadernos de Historia de España, Buenos Aires, 29/30, 1959, p. 5-124.

${ }^{3}$ Los Nombres Personales en las Inscripciones Latinas de Hispania, Múrcia, 1994.

${ }^{4}$ Cf. Francisco Beltrán, Javier de Hoz e Jürgen Untermann, El Tercer Bronce de Botorrita (Contrebia Belaisca), Saragoça, 1996.
} 
unânime que será pré-romano: radicará numa forma Mael-, relacionável com o irlandês antigo mael, onde tem o significado de "escravo", ou com o antigo galês mail, derivado da raiz "mai-, que quer dizer 'cortar'. Eu traduzo o nome por Melão e - para terminarmos este 'estranho' excurso com uma nota de graça - o "melão" é mesmo para ser cortado... em talhadas!

E saborear um bom melão torna-se infinitamente mais fácil que embrenhar-nos neste labiríntico mundo da onomástica pré-romana peninsular!...

\subsection{O nome do pai}

Reflectiremos agora, por uns momentos, acerca da presença da filiação na identificação de uma pessoa em inscrições.

E talvez não seja despiciendo recordar de novo como, entre nós, em meios pequenos, designadamente nas aldeias onde todos (ainda) se conhecem, se falar, por exemplo, do António do Manel, querendo com isso significar que é o António, filho do Manel. Um hábito, aliás, que vem de remotas eras: não nos referimos nós ao primeiro rei de Portugal como Afonso Henriques, numa tradução directa do latim, Alphonsus Henrici?

Tanto num caso (o popular) como no outro (o erudito), a omissão da palavra "filho" resulta natural, pois é uma relação que se subentende.

Ao tempo dos Romanos, como habitualmente o filho tomava o praenomen do pai (mormente após a introdução do cognomen), a omissão de filius (ainda que escrita em sigla) não deve ter ocorrido. No entanto, entre os indígenas, a partir do momento em que tentaram latinizar os seus nomes, nem sempre a palavra filius é mencionada: Amoena Reburrié a "Amena de Reburro". E quase seria tentado a afirmar que é com o progresso da aculturação onomástica que a sigla F F(ilius), F(ilia) - vai aparecendo. Por outro lado, sou de opinião que, estando a palavra omitida, ela se deve omitir também na tradução da epígrafe para língua portuguesa, na medida em que preconizo, cada vez mais, a fidelidade à linguagem epigráfica, naturalmente diferente da linguagem comum e da linguagem literária, ainda que, ali e aqui, possam ocorrer óbvias 'contaminações'. 
Por conseguinte, a menção do patronímico é, em primeiro lugar, um elemento de identificação: é a Amena de Reburro e não a Amena de Tangino; é o Gaio Júlio, filho de Gaio, e não o Gaio Júlio, filho de Quinto.

\subsubsection{A omissão do patronímico}

Mas tal menção é também índice de situação sociojurídica: quem, na sua identificação, inclui o patronímico, quer com isso significar que é de condição livre (ingenuus), não tem vergonha do pai que tem. Os escravos não têm patronímico; os libertos também não; os indígenas, por vezes, também o não referem nas inscrições, dado que tal referência mostraria uma origem indígena que, amiúde, lhes interessará ocultar.

Não é, porém, assim tão linear o significado da omissão do patronímico.

O tipo de monumento em que o nome aparece poderá, em alguns casos, ter determinado tal omissão. Se, no caso de um ingenuus que figura em monumento público, mormente porque homenageado ou autor de determinada obra (inscrições honoríficas e monumentais), o patronímico em regra deve consignar-se, já o mesmo se não poderá dizer com tamanha evidência de inscrições funerárias - a serem colocadas em recinto familiar e, por isso, sem grandes necessidades de identificação específica - ou de inscrições votivas - onde o recato postula uma identificação sumária. De facto, numa inscrição votiva, a filiação pode ser omitida, sem que isso detenha outro significado para além da humildade perante a divindade, que a todos conhece bem, ou inclusive perante a comunidade: o mais importante é o vínculo religioso, sem alardes. Nas placas dedicadas ao taumaturgo Dr. Sousa Martins, não se identificam os devotos amiúde apenas através de siglas cujo significado só eles conhecem? Não acontece o mesmo nas «orações ao Divino Espírito Santo" que se publicam nos jornais em cumprimento de promessa?

Há, porém, casos de omissão da filiação que podem denunciar situações determinadas. Exemplifiquemos com dois epitáfios do aro de Alcácer do Sal, a romana Salacia, zona assaz cosmopolita desde os primórdios da vinda dos Romanos para o território actualmente português. 
Uma ara funerária (IRCP 196) achada perto da capela de S. João dos Azinhais, na freguesia do Torrão, ostenta o seguinte texto:

\section{$\mathrm{L} \cdot \mathrm{RVBRIVS}$}

PRISCINVS

$\mathrm{ANN} \cdot \mathrm{XXVI} \cdot \mathrm{H} \cdot \mathrm{S} \cdot \mathrm{E}$

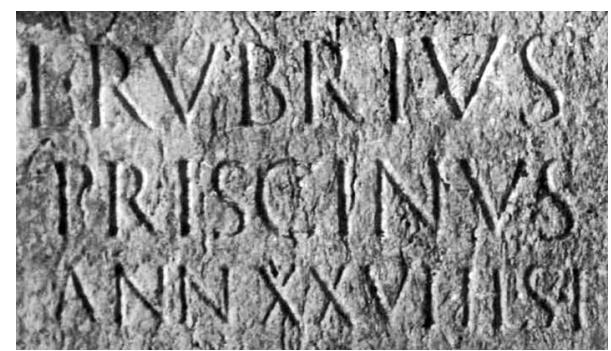

Numa circunstância destas - em que, mui provavelmente, foram os pais os dedicantes do epitáfio, atendendo à idade (26 anos) em que a morte ocorreu era normal que não só eles viessem mencionados nessa qualidade, como surgisse a sigla do nome do pai. Poderá aduzir-se não ser esse um hábito na altura, uma vez que, pela paleografia, o texto pode datar-se de meados do século I da nossa era. Poderá falar-se também de estética na paginação: ficava mal algo como L. F no final da linha 1... Creio, todavia, não serem essas razões plausíveis: se os dedicantes quisessem, o ordinator teria escolhido outro módulo de letra e saberia dispor o texto doutra forma.

Neste caso, o epigrafista considera que houve uma omissão voluntária e, como o defunto vem identificado à maneira latina, com os tria nomina (praenomen, nomen, cognomen), pondera a hipótese de estarmos perante um indígena romanizado, ou seja, alguém que, sendo de estirpe autóctone, foi integrado na comunidade romana, eventualmente por intermédio de um elemento notável da gens Rubria, adoptando, por isso, o seu habitual modo de identificação (os nomes são perfeitamente latinos). E, então, porque não a filiação? Porque o pai é certamente um indígena, de nome 'estranho', e... prefere manter-se no anonimato!

\subsubsection{Os que não são filhos... do pai}

E se nunca esperaríamos que, em inscrição de escravo, o nome de seu pai aparecesse, pois escravo "não tem pai", igualmente um liberto omite a sua filiação, pois... filho de escrava, quem poderia ser o seu pai? 
O outro exemplo seleccionado é uma elegante estela (IRCP 193) em cujo campo epigráfico se lê este epitáfio:

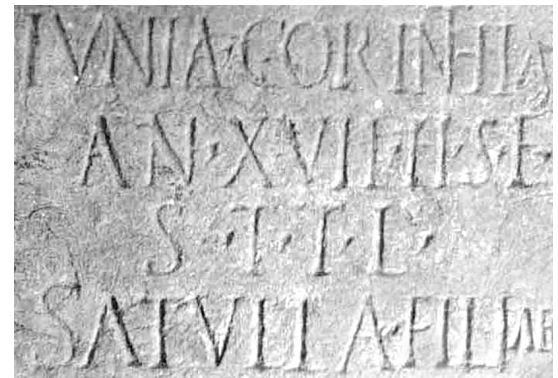

\author{
IVNIA $\cdot$ CORINTHIA \\ $\mathrm{AN} \cdot \mathrm{XVII} \cdot \mathrm{H} \cdot \mathrm{S} \cdot \mathrm{E}$ \\ $\mathrm{S} \cdot \mathrm{T} \cdot \mathrm{T} \cdot \mathrm{L} \cdot$ \\ SATVLLA $\cdot$ FILIAE
}

Também aqui seria normal que ambos os progenitores fizessem a dedicatória, atendendo a que Corinthia morre aos 17 anos. Contudo, é à mãe que pertence a iniciativa, sendo omitido o nome do pai. Sem que precisemos de invocar, aqui, o papel importante que a mulher parece ter exercido na Lusitânia Ocidental - que Luís da Silva Fernandes oportunamente sublinhou (cf. Portugalia 19-20 1998-1999 129-228) - o certo é que o cognomen Corinthia indicia, pela sua ressonância grega (note-se a grafia com th), estarmos, mui provavelmente, perante a liberta de uma gens Iunia. Daí a omissão do patronímico.

Concluindo: a omissão do patronímico na identificação de uma personagem não implica necessariamente que estejamos em presença de um não ingenuus.

\title{
1.5.3 Duas mães?
}

Interessante igualmente deste ponto de vista é o epitáfio procedente de Mouriscas, uma freguesia do concelho de Abrantes, hoje guardado no Museu Nacional de Arqueologia.

O defunto, Decumus de seu nome, falecido aos 12 anos, vem identificado como filho de Placência; e recordam-no Placência e Júlia, ambas considerando-o seu filho: Placentia et Iulia filio f(aciendum) c(uraverunt).

Quando, com Joaquim Candeias da Silva, reexaminámos esta epígrafe ${ }^{5}$, escrevemos, a propósito de vir mencionado o nome da mãe e não o do pai:

\footnotetext{
${ }^{5}$ Cf. Abrantes (Cadernos para a História do Município) 1, 1982, 30-31.
} 
«Não vamos considerar, por isso, que se trata dum filho natural, embora seja evidentemente de estranhar, para a nossa mentalidade, que, figurando o nome da mãe, não figure o do pai no epitáfio duma criança de doze anos. Tanto mais que, ao lado da mãe, surge uma outra dedicante, cujo grau de

parentesco com Decumus nem sequer vem referido - e ambas rendem homenagem ao filho".

Preferimos, então, ver aqui um sintoma de índole predominantemente cultural: "O conhecimento diminuto das regras da linguagem epigráfica".

Hoje, não estaria tão seguro dessa opinião, mormente sabendo que nem tudo, num epitáfio, se rege por mero subjectivismo. Há, na verdade, uma mensagem consciente a transmitir, imorredoira. E, aqui, a paternidade foi deliberadamente omitida - e são duas mulheres que não hesitam em assumir-se como 'mães', irmanadas numa ternura sem par.

\subsubsection{Os filhos ilegítimos}

Mas... e se estivermos em presença de um filho ilegítimo? Num contexto social restrito, tal como hoje em certas comunidades onde a mulher detém importante papel no seio da família, chamar alguém de "O Manel da Maria", sendo Maria a sua mãe (poderia, noutro contexto e noutra idade, ser a esposa), não detém outro significado senão esse: a ausência do papel identificador do nome do pai.

Entre os Romanos, em meio restrito também, não se veria inconveniente em que claramente se assumisse a ilegitimidade, de todos aliás conhecida. E, em meio indígena, já temos encontrado inscrições em que a filiação se faz pelo lado materno. Quando, porém, gentilício de mãe e filho coincidem, temos sérias probabilidades de estarmos perante uma filiação ilegítima que frequentemente se oculta, assumindo o filho uma paternidade fictícia, por exemplo através do praenomen do avô.

Cidadãos romanos e indígenas prestavam serviço militar. Nessas circunstâncias, figuravam em listas de que, felizmente, nos restaram alguns testemunhos 
quer em tabulae de bronze, os chamados diplomata militaria, quer em epígrafes votivas em que os soldados passados à disponibilidade, ou seja, usufruindo da honesta missio, vêm nomeados em aras votivas, como se a autoridade imperial ali comungasse com a auctoritas divina.

Neste caso, havia que obedecer, digamos assim, a uma estética, a uma paginação cuidada: praenomen, nomen, filiação, cognomen... - tudo devidamente alinhado. E se um dos soldados era ilegítimo e só agora se punha o problema de lhe serem atribuídos os tria nomina e nome de pai? O estratagema algumas vezes usado foi de, inteligentemente, deixando-a expressa, ocultar a ilegitimidade! Como assim? Muito simples: colocando no lugar da filiação Sp. F. Numa leitura apressada, ninguém repararia que Sp. F. significava exactamente $S p$ (urii) F(ilius), ou, para sermos gramaticalmente mais correctos, Sp(urius) F(ilius), "filho espúrio", "bastardo”. Dir-se-á: mas o praenomen Spurius não existiria, decerto!... Existia. E o gentilício também. Numa bonita urna de mármore procedente de Milão (CIL V 5380), a mãe Sentia Apphia honra os deuses Manes Q(uinti) Spuri Sentiani. Trata-se, sem dúvida, de filho natural, a que a mãe, liberta, dá um cognome (Sentianus) formado a partir do seu gentilício. O pai está, de novo, 'ausente'.

Custa-nos compreender - ia a escrever "aceitar" - este último mecanismo. Talvez as fontes literárias (as peças teatrais, por exemplo) nos possam oferecer eco de eventuais reacções a este costume. O desafio aqui fica para os estudiosos da Literatura.

\subsubsection{As... linhagens}

Recordo frequentemente aquele pintor que incluía no currículo, como algo de relevante, o facto de ser neto do senhor que figurava em determinada nota (dinheiro) do seu país de origem. E de como, maldosamente, acabei por não lhe fazer a crítica da exposição e elaborar um texto cheio de encómios à figura do seu avô...

É verdade: cada um devia valer por si mesmo e não se apresentar como "filho de...", "neto de...". Contudo, se no primeiro caso, como vimos, a questão é 
quase de ordem legal (hoje, a indicação do nome dos pais faz parte integrante da nossa identificação), quando, numa inscrição latina, surge a identificação do avô, estamos seguramente perante um caso de prestigiosa família local.

Assim o interpretei, por exemplo, em relação a T. Rutilius Tuscillianus, que, homenageado em Balsa por um grupo de amici (os seus clientes políticos...), vem mencionado como filho de Q. Rutilius Rusticinus e neto, pelo lado materno, de T. Manlius Martialis - uma ligação entre a gens Rutilia e a gens Manlia, ambas importantes na burguesia balsense, que muito importava salien$\operatorname{tar}(\mathrm{cf}$. IRCP 80).

Curioso é também o facto de, nesta inscrição, o nome do pai e do avô virem escritos por extenso: mais um sinal do prestígio que se pretende realçar.

\subsection{A tribo, índice seguro de cidadania}

Outro dos elementos que constituem a identificação do cidadão romano é a menção da tribo a que ele pertence.

Digo bem: uso o masculino, porque as mulheres - salvo raríssimas excepções - não se integram oficialmente em tribo nenhuma; uso 'cidadão', porque só os cidadãos romanos de pleno direito detêm o privilégio de pertencer a uma tribo.

Daqui se conclui que a menção da tribo é a prova mais evidente, peremptória, de que estamos em presença de um cidadão romano; da omissão da tribo não se pode, porém, concluir, sem mais, que o indivíduo em causa não é cidadão.

$\mathrm{Na}$ verdade, tal como hoje nós próprios nos não identificamos sempre com o nome todo e - muito menos!... - com a indicação dos pais ou da naturalidade, também, ao tempo dos Romanos, nem em todas as inscrições tal se verifica.

Assim, numa inscrição funerária de índole privada, digamos assim, destinada a ser colocada em sepulcro familiar, é provável que a identificação não inclua a tribo. Num texto votivo, não fica bem ao devoto fazer alarde da sua condição político-administrativa. Num texto monumental, o benemérito de quem partiu a iniciativa da construção e a pagou ou os responsáveis pela sua execução serão, obviamente, tão conhecidos na comunidade que não carecerão de identifica- 
ções escusadas. Agora, numa dedicatória, em que o cidadão é o alvo da homenagem, a forma oficial de se identificar será, naturalmente, a preferida.

Sabe-se que se atribui a Sérvio Túlio a divisão da população romana em tribos, de acordo com um critério geográfico, ou seja, tendo em atenção o local das "sete colinas" em que determinada família se instalara. A referência a essas tribos - assim como, na actualidade, não é indiferente dizer-se que se tem residência na Lapa (em Lisboa) ou num dos bairros periféricos da capital... - era um critério de distinção social. Por isso, independentemente de o significado localista (digamos assim) inicial se haver perdido, ser da tribo X constituiria, sem dúvida, pelos tempos fora, um índice de status não despiciendo.

Sendo o sinal visível da cidadania adquirida, o indígena cidadão 'de fresca data' jamais se esqueceria de a referir (qual recém-licenciado impante que encomenda de imediato cartão de visita a condizer...). Por vezes, não contente com a explicitação em abreviatura, como era de uso, pois que, sendo apenas dezoito as mais correntes, fácil era identificá-las todas, mandava-a gravar por extenso, não fosse Mercúrio tecê-las e alguém da sua lidação, menos atreito a estas coisas da administração e dos costumes, não soubesse o verdadeiro significado das letras.

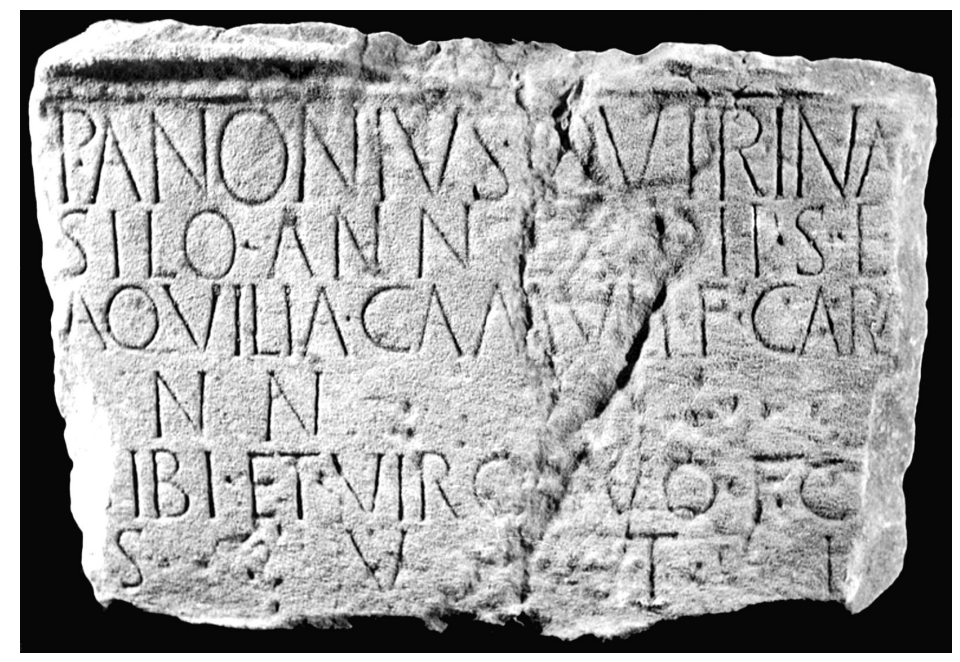


Assim acontece, por exemplo, com esta placa funerária de Vaiamonte, concelho de Monforte (IRCP 578): Aquilia Cara, filha de um indígena, Camulus, manda lavrar, em vida, o epitáfio do marido e dela (daí que, na linha 4, esteja por preencher o espaço para a menção da sua idade, quando morrer); o marido fora, porém, elevado à cidadania, tem os tria nomina, como é de lei, dele se omite a filiação (o pai seria um indígena...), mas... escreve-se bem por extenso a tribo a que foi adscrito: a Quirina (linha 1)!

\subsubsection{Um indice cronológico}

Por diversas vezes se tem acentuado o carácter duradouro, de "mensagem para sempre", do texto epigráfico e a consequente omissão de elementos passíveis de nos permitirem uma datação segura.

Ora, a presença ou ausência da menção da tribo pode - em associação com outros elementos - ser um índice cronológico válido.

$\mathrm{Na}$ verdade, se em relação ao território actualmente português a quase totalidade dos monumentos epigráficos conservados datam do Império, sabemos que foi hábito dos imperadores atribuírem às cidades que fundavam a tribo de sua preferência. Desta sorte, há inúmeras (Olisipo, Bracara Augusta, Ebora, Pax Iulia, Salacia...) cujos cidadãos foram inscritos na tribo Galéria, por haverem sido fundadas logo nos primórdios do Império ou mesmo nos finais da República, em que a tribo Galéria foi a dominante. Em contrapartida, Conimbriga, a civitas Igaeditanorum (Idanha-a-Velha), Collippo, Ammaia, Balsa, Aquae Flaviae, entre outras, são já da tribo Quirina, que, segundo uns, teria sido atribuída, pelo menos nalguns casos esporádicos, a partir do imperador Cláudio e, seguramente, durante a dinastia dos Flávios, na segunda metade do século I da nossa era.

Essas - a Galéria e a Quirina - são, de facto, as duas tribos mais frequentes no território actualmente português. Isso não impede, porém, que Scallabis uma colónia bem ligada às guerras civis imediatamente anteriores ao advento de Augusto - seja da tribo Sergia. Mérida, por seu turno, a colónia Augusta Emerita 
que o imperador Augusto criou para ser capital da Lusitânia, foi adscrita à tribo Papíria.

Frequente nos séculos I e II, a referência à tribo começa a entrar em desuso 100 a partir do Édito de Caracala (212), por motivos óbvios (a cidadania é alargada a todos os habitantes livres do Império), e omite-se por completo sob Aureliano (270-275).

\subsubsection{Uma informação complementar}

Hoje em que - como sempre, aliás, entre os Homens e entre os animais - o ‘território' é algo de muito importante e, daí, que a pesquisa sobre os limites territoriais de uma cidade antiga entusiasme os investigadores, a menção da tribo numa inscrição reveste-se, nesse âmbito, de um significado particular.

Exemplifico:

- No chamado Castro dos Três Rios, um sítio arqueológico entre os concelhos de Viseu e Tondela, refere-se um Lucius Manlius, filho de Decimus, inscrito na tribo Aemilia. Ora, essa tribo não aparece referenciada como pertencendo a alguma cidade romana peninsular. Conclusão: estaremos perante um dos colonos recém-chegados.

- Na zona de Torres Vedras, abundam os indivíduos inscritos na tribo Galéria. Deduziu-se desse facto que o termo do ager Olisiponensis incluía também aquela área geográfica.

- Na fachada da igreja de Nossa Senhora do Mileu, em Veiros (Estremoz), está embutido o epitáfio de Sextus Aebutius Rufinus, inscrito na tribo Papíria. Não se sabe, com exactidão, donde o mesmo terá vindo; contudo, atendendo a que também uma placa procedente da Herdade da Granaria, sita no mesmo território de Veiros, memora L. Marius Caprarius igualmente da tribo Papíria, é evidente que os historiadores possuem aqui argumentos fortes para considerar essa região como tendo pertencido ao ager Emeritensis. 


\subsubsection{Em ablativo}

Na identificação, a menção da tribo vem após a filiação, em ablativo e geralmente em sigla, como se disse: $\operatorname{GAL}($ eria $), \operatorname{PAP}($ iria $) ..$

É habitual, quando fazemos a leitura interpretada de um texto, preferirmos acrescentar a palavra tribu: QVIR(ina tribu), por exemplo. Não é obrigatório, facilita a compreensão, mas a sua omissão nas epígrafes constitui uma regra com raras excepções. Ou seja, dizer que se era "da Galéria" tornava-se perfeitamente compreensível na linguagem quotidiana e, por conseguinte, na epigráfica também.

Poder-se-á, pois, discutir se deveremos, ou não, continuar a fazer tal explicitação. Penso que, numa primeira fase, se o 'receptor' da mensagem for um iniciado ou mesmo um leigo, a explicitação detém justificação plena. Pouco a pouco, porém, poderemos omiti-la.

E em ablativo, porquê?

Trata-se, como vimos, de uma circunstância de lugar, indica o território a que o cidadão está adscrito e o ablativo é o caso para tal adequado.

\subsubsection{Hereditariedade?}

Uma outra questão se põe, todavia. Lógico que, paulatinamente, o carácter estritamente geográfico da tribo foi perdendo importância. Sabemos, por exemplo, que, em geral, os filhos dos libertos eram, em Roma, inscritos na tribo Palatina. Não nos admira, pois, que o filho de um cidadão da tribo Galéria mantenha a tribo do pai, ainda que nado em cidade diferente da paterna. O carácter hereditário, pessoal, familiar, sobreleva, então, o estritamente geográfico. E há mesmo quem pense que este será um caso muito mais frequente do que se imagina.

Esse facto leva-nos a uma outra consideração de não somenos curiosidade. É que, para ser magistrado em determinada colónia ou município, imprescindível se tornava, obviamente, que dessa colónia ou município se fosse cidadão. 
Em tal circunstância, quem detinha pretensões a que a sua descendência seguisse carreira política na cidade para que emigrara, não desdenharia, decerto, que o filho passasse a ter a tribo local. Daí a disparidade ou mesmo duplicidade de tribos que, por vezes, se verifica: a tribo de origem e a da cidade onde foram recebidos como cidadãos, passíveis, portanto, de virem a ocupar cargos públicos ${ }^{6}$.

No território actualmente português, um dos casos mais eloquentes a tal respeito é o de G. Blossius Saturninus, cujo itinerário já tive ensejo de referir com alguma detença ${ }^{7}$. Originário da Colonia Iulia Neapolis, fundada por César na África Proconsular, cujos vestígios se encontram perto da actual Nebel Kedim, Saturninus (e este é um cognome bem típico do Norte de África) afirma claramente pertencer à tribo Arniensis; mas no monumento tumular que dedica à filha, não se esquece de mandar gravar, por extenso, GALERIA. Há, por conseguinte, uma dupla pertença: por nascimento, à tribo Arnense; por adopção, à Galéria, que é a de Pax Iulia (Beja), colónia onde foi acolhido e onde, seguramente, seguiu carreira política.

\subsubsection{Mulberes...}

Sendo apanágio dos cidadãos romanos, às mulheres não competiria atribuição de tribo. Casos há, no entanto, em que excepcionalmente tal acontece. De acordo com as investigações levadas a cabo por Giovanni Forni, que foi, sem dúvida, o historiador que mais se interessou pelo tema, tal ocorre "sobretudo em epígrafes de África e principalmente nas antigas cidades de Thibilis e Castellum Celtianum» ${ }^{8}$. Da Península Ibérica, conhecia-se um caso em Ampúrias 9 e outro

6 Cfr. Giovanni FORNI, "Doppia tribù" di cittadini e cambiamenti di tribù romane. Probabile connessione con l'esercizio dei diritti politici in municipi e colonie", Tetraonyma, Génova, 1966, p. 143 e seg.

7 Além do que escrevi em comentário à sua inscrição (Inscrições Romanas do Conventus Pacensis, Coimbra, 1984, inscrição no 294), apontei-o como exemplo da ligação entre a província romana de Africa com a Lusitania, nos começos do Império: cf. "L'Africa et la Lusitania: trois notes épigraphiques", L'Africa Romana 13, Roma, 2000, p. 1291-1298, sobretudo p. 1291-1292.

${ }^{8}$ Giovanni FORNI, "La tribu Papiria di Augusta Emerita", Augusta Emerita, Madrid, 1976, p. 33-42.

9 Ampurias XXX 1968 p. 338. 
em Aeso ${ }^{10}$; contudo, de Mérida, cita Cretonia Maxima Pap(iria) Pacensis, mãe de P. Aplanius Marcianus Pap. Emeritensis (AE 1971, 147), que constitui, na verdade, um outro caso interessante, cuja 'história' poderíamos imaginar assim: natural de Pax Iulia, Cretónia notabilizou-se em Badajoz (onde foi encontrada a epígrafe) para onde se transferira, quiçá por via do matrimónio com um Aplanius (importante cidadão emeritense?). Honorificamente outorgaram-lhe, pois, a tribo da colónia e o filho - por mor das dúvidas... - também na inscrição, além da menção da tribo (que seria o bastante para the conhecermos a naturalidade), é identificado como Emeritensis.

O outro caso registado é o de Aquilia Severa Papiria Emeritensis, a quem o filho, M. Septimius Severus, manda erigir uma ara funerária de már-

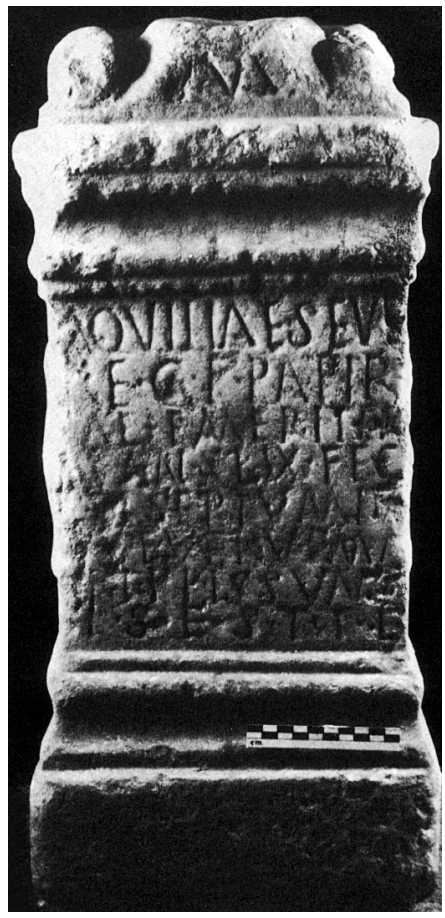

A ara de Aquilia Severa Papiria Emeritensis, de Olivença (Badajoz). Foto de José L. Ramírez

more, encontrada em Olivença (Badajoz). E a curiosidade desta identificação reside ainda no facto de, estando o nome da defunta em dativo, Papiria se apresenta em dativo também - Papiriae - como se de cognomen se tratasse. Que eu saiba, nenhum dos autores que estudou o monumento ${ }^{11}$ deu importância a esse facto; o certo é que, em meu entender, tal 'confusão' resulta, mui provavelmente, de um hábito quotidiano ou de um formulário corrente que se aplicava fundamentalmente na identificação dos homens e que, neste caso, se tornou extensivo a uma mulher que se desejava mostrar claramente como oriunda de Emerita Augusta; e, como víramos no exemplo anterior, não seria anormal que se ajuntasse o nome da tribo ao próprio etnónimo. Por consequência, neste

\footnotetext{
${ }^{10}$ L'Année Épigraphique (=AE) 1972, 313.

11 Quem estudou o monumento mais em pormenor, inclusive apresentando foto, foi José L. RAMÍREZ SADABA, "Las inscripciones de la mininecrópolis de "El rincón de Gila" (Badajoz)", Aurea Saecula, no 10 , Barcelona, 1993, p. 251-266, sobretudo p. 257-258 e fig. 7. Aí se refere a quem já tinha aludido ao monumento sem, contudo, o haver totalmente estudado do ponto de vista epigráfico.
} 
último caso, mais do que ver em Aquilia Severa uma senhora tão importante que se impunha a sua inscrição na tribo da cidade, poderemos optar por anotar aqui um reflexo desse quotidiano não suficientemente consciencializado do seu efectivo valor.

\subsection{7 ... e soldados}

Com os soldados dava-se, por seu turno, um caso deveras interessante.

Quando se alistava, era naturalmente inscrito o seu nome num rol apropriado, em que a estética - e temos disso bastos exemplos - desempenhava um papel normativo, até para evitar enganos. Ou seja, cada nome em sua linha, o praenomen debaixo doutro praenomen, o gentilício sob outro gentilício, a tribo debaixo da tribo... E se o soldado não tinha tribo, como fazer? Designadamente se nascera da união ilícita de um soldado em serviço?

É daí que aparece a menção da tribo Pollia, que denuncia precisamente a origo castris (nascido num acampamento...). Castris não é propriamente uma origo; contudo, juntamente com a menção da tribo Pollia que amiúde a acompanha corresponde a uma indicação provisória, para fins de registo dos recrutas nas listas, válida apenas até ao momento em que tivessem encontrado, após o licenciamento, uma domus específica. Aplicava-se, pois, não só aos filhos de legionário e de mãe peregrina mas também aos filhos non iusti, nados de legionário em serviço e de mãe romana, sem ligação necessária nem com o estado peregrino das civitates donde eram oriundos nem com os canabae (aqueles aglomerados civis que se formavam em torno dos acampamentos).

Trata-se, pois, da inscrição numa tribo fictícia. Os seus portadores não eram cidadãos romanos, detinham a condição "peregrina" e só poderiam vir a obter a cidadania se se alistassem nas legiões e cumprissem integralmente o serviço militar.

Na epigrafia do território actualmente português ainda se não encontrou nenhum caso desses - mais vulgar em zonas habitualmente militarizadas; no entanto, a circunstância de, numa inscrição achada no concelho de Pombal, se 
ter registado o raro gentilício Pollius levou a suspeitar que os seus portadores poderiam ter sido descendentes de antigos legionários romanos ${ }^{12}$.

\subsection{A naturalidade}

Se, hoje, a nossa identificação em documentos oficiais não prescinde da naturalidade, raro é que tal informação conste num epitáfio, até porque se parte do princípio que são, na sua maioria, os naturais de uma freguesia que ficam sepultados no cemitério local. Há excepções, como no caso de S. Brás de Alportel, onde, desde sempre, se institucionalizou o hábito de incluir na pedra tumular o local de residência do defunto, pois que se trata de concelho com uma freguesia apenas e cemitério único.

Também ao tempo dos Romanos a indicação da origo se revestia de carácter excepcional.

Vemo-la no rol dos militares passados à disponibilidade honesta missione, pois que como tal constavam nas listas oficiais e cada unidade detinha elementos de variadas procedências: C(aius) Melamus C(aii)f(ilius) Gal(eria) Rufinus Salacia miles coh(ortis) VIII (octavae) pr(aetoriae). Vemo-la em circunstâncias específicas, quando se quer acentuar a diferença ou mostrar o orgulho que do homenageado têm os seus concidadãos: L(ucio) Marcio Piero, Pacensi, augustali col(oniae) Pacensis et municipii Eborensis...

Sendo complemento circunstancial de lugar donde, vem em ablativo: Olisipone, "de Olisipo"; C(aius) Rittius C(aii) f(ilius) Vol(tinia) Paulus Vienna. Raro é, porém, que a terminação do topónimo seja gravada, de modo que, amiúde, tanto se poderá entender Olisip(one) como Olisip(onensis), ou seja, um adjectivo.

12 Cf. LAPA, Maria Fernanda Moreno, "Descendentes de legionários romanos viveram em Pombal", Diário de Coimbra, 26-11-1987, p. 2. AE 1995, 729; HEp 61996 no 1044. 


\subsubsection{O significado}

Se, numa turma, há dois Joões e um deles tem acentuada pronúncia alentejana, fácil é que comecemos a distinguir esse como "o João Alentejano"; se um outro tem pronúncia à moda de Viseu, é bem provável que comece a ser conhecido como «O Viseu". Tal acontece em universidades como Lisboa ou Coimbra, onde, independentemente do seu apregoado carácter inter-regional, sempre se parte do princípio de que a maioria dos estudantes ou são da área metropolitana de Lisboa ou da de Coimbra, respectivamente. Um João "Alentejano" em Évora seria... pleonasmo!

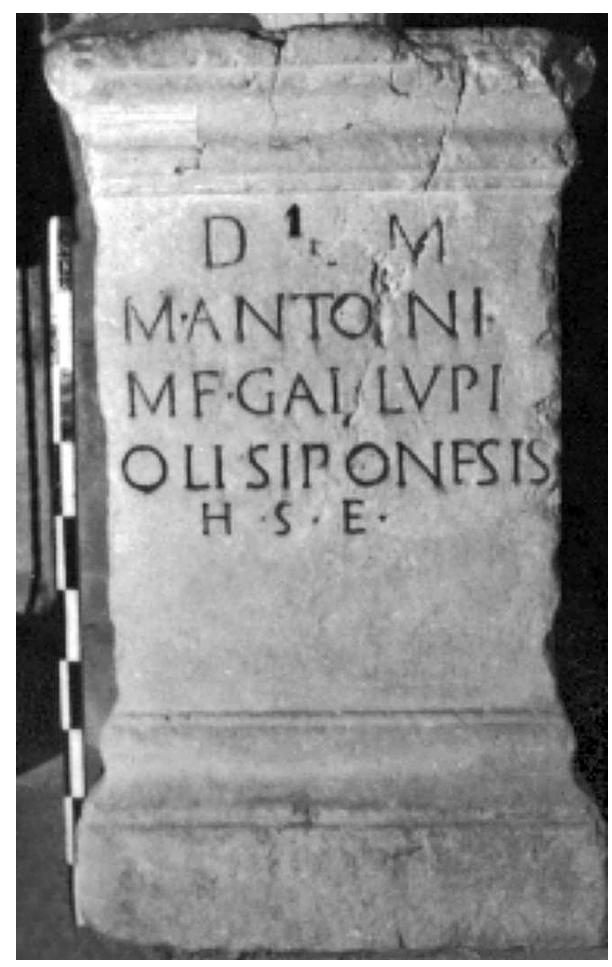

Partiu-se, pois, desse raciocínio para concluir que a menção da naturalidade numa inscrição romana era a excepção num local. Dizendo doutra forma: se, num epitáfio, se diz que alguém é Olisiponensis, tal quererá dizer que ele se encontra deslocado da sua terra natal e, portanto, ali não é Olisipo. O caso de Olisipo é evidente, porque sabemos onde fica Olisipo; mas o epitáfio de um Talabrigensis só pode provar que... ali não é Talabriga, uma civitas cuja exacta localização, de resto, ainda se desconhece.

Foi encontrada na zona de Santarém a ara funerária de $M$. Antonius Lupus, cidadão inscrito na tribo Galéria e que se identifica como Olisiponensis $^{13}$. Ora aqui está: o cidadão encontrava-se no território de uma outra civitas, Scallabis, cuja tribo era a Papiria; por isso, carecia de melhor identificação e de afirmação da sua naturalidade, de que a família se orgulhava.

\footnotetext{
${ }^{13}$ Aliás, valha a verdade, o que vem na pedra é Olisiponesis, omissão de $n$ que frequentemente se regista e que será mais um reflexo da linguagem oral, de que já falámos.
} 
De resto, para nós, esta junção da tribo e da origo na identificação de um personagem reveste-se da importância que facilmente se compreende, pois que assim se tem uma prova cabal da tribo a que a cidade fora adscrita.

\subsubsection{Origo ou cognome?}

Os dois exemplos atrás citados, que são, diga-se de passagem, casos reais, não inventados - dos estudantes "Viseu" e "João Alentejano" - levam-nos a uma outra questão, que não é de somenos: quando o cognome é etimologicamente formado a partir de um topónimo, estamos perante um verdadeiro cognomen ou da indicação da origo?

Eu creio que a resposta se deva considerar afirmativa nos dois sentidos: é um cognome formado a partir da origo. Num eventual M. Cassius Olisiponensis, "Olisiponensis" é cognome e dá indicação de naturalidade.

Tenho, a este propósito, um exemplo elucidativo, datado dos primórdios do século XX em Cascais. Entre as levas de trabalhadores ribatejanos veio um Joaquim. "E tu donde és?", perguntaram-lhe os companheiros. "Da Ereira", respondeu. Passou a ser o "Ereira»: Joaquim Ereira. E o apelido passou oficialmente para filhos e para netos!

\subsubsection{Outras proveniências}

Podem ocorrer também outras informações no que à proveniência diz respeito e que servem, às mil maravilhas, para estudos de âmbito demográfico.

Alguém pode designar-se simplesmente natione Afer, para indicar vagamente a sua proveniência africana, sem especificar o exacto local de origem. De resto, os noticiários hoje em dia não se referem amiúde a indivíduos "de origem africana" sem mais especificações?...

Além da naturalidade, poderá interessar igualmente o domicílio (como no caso dos epitáfios de S. Brás de Alportel). Dir-se-á então: domo Roma (em ablativo), domo Pisauri (em genitivo) ou domo Termestinus (adjectivo). 
Um caso que muita tinta tem feito correr - e sobre o qual ainda recentemente Jorge de Alarcão produziu um substancial ensaio ${ }^{14}$ - prende-se com a menção de naturalidade patente em epígrafes do Noroeste peninsular e que se referem ao que, na esteira dos estudos de María de Lourdes Albertos e à falta de indicação precisa acerca do verdadeiro significado desses nomes, se tem chamado "organizações suprafamiliares" ${ }^{15}$. É que, para além da origo propriamente dita, houve elementos desses povos que fizeram questão em deixar patente a sua pertença a uma comunidade mais pequena. Assim, temos um Reburrus Ari Seurus (centuria) Narelia... "Reburro de Aro, Seuro, da centúria Narélia". Acontece, porém, que o que se desdobrou aqui como centuria vem indicado na epígrafe apenas com um C invertido; na verdade, nas epígrafes 'clássicas', digamos assim, um C invertido é sinónimo de 'centúria', pois que 'centurião' também assim se assinala. Mas... o que é uma centúria em contexto indígena? E porque não será de interpretar-se castello, se encontramos, por exemplo em Garvão (Ourique) (IRCP 122), um Ladronus Dovai, que se diz Bracarus castello Durbede? Creio não ser possível chegar a uma conclusão segura, designadamente porque os indígenas terão assimilado a nomenclatura romana mas sem a aplicarem numa precisa conotação jurídico-administrativa.

Em todo o caso, uma conclusão geral pode tirar-se: se exceptuarmos a documentação de teor oficial em que (tal como acontece connosco, actualmente) a menção da naturalidade é obrigatória, a sua presença em epitáfios ou em textos honoríficos romanos detém um significado primordial: o orgulho que se tem na pertença a determinada comunidade ${ }^{16}$.

\footnotetext{
14 "A organização social dos povos do Noroeste e Norte da Península Ibérica nas épocas préromana e romana", Conimbriga 422003 5-115.

15 ALBERTOS (María de Lourdes), Organizaciones Suprafamiliares en la Hispania Antigua, Valladolid, 1975.

16 Sobre esta temática e outros meios a que, em Epigrafia, se pode recorrer para usar estes dados como fonte para os estudos demográficos, pode consultar-se o capítulo "O que sou e donde venho" dos meus Estudos sobre Epigrafia, Minerva, Coimbra, 1998, p. 101-109.
} 


\section{O CURSUS HONORUM}

Tal como hoje acontece no funcionalismo público, no exército ou na orgânica de qualquer instituição - também ao tempo dos Romanos havia quadros de etapas mais ou menos rígidas para quem neles quisesse ingressar. É o que se designa em Latim por cursus honorum (literalmente, a "carreira das honras").

Essa carreira surge frequentemente em inscrições honoríficas, quer na ordem directa quer na ordem inversa (do cargo mais importante para o menos importante). Aliás, a contribuição da Epigrafia para a reconstituição das etapas desse currículo é imprescindível; nisso se baseiam também os estudos prosopográficos ${ }^{17}$.

Embora a carreira senatorial seja distinta da carreira equestre ou das carreiras municipais, há-de referir-se a permeabilidade entre estas "classes": o burguês municipal tem boas perspectivas de ascender a cavaleiro e o cavaleiro - por mérito pessoal, pela riqueza, pelo favor imperial (adlectio) - pode ser inscrito na ordem senatorial.

Timocrática no seu início, a sociedade romana escalonou as suas classes de acordo com o rendimento colectável dos cidadãos. O montante desse rendimento classificativo variou ao longo dos séculos (o senador deveria ter como rendimento mínimo, no Alto Império, um milhão de sestércios!...). E o próprio cursus honorum nem sempre manteve a rigidez inicial - como ainda hoje acontece com as promoções no exército ou na administração...

O esquema que apresentamos é válido sobretudo para o Alto Império.

\subsection{A carreira senatorial}

O senador (vir clarissimus) entrava, a partir dos 18 anos, nas funções preliminares, que o introduziam na orgânica administrativa e militar: um dos cargos do vigintivirato ${ }^{18}$ ou o tribunado dos soldados numa legião.

\footnotetext{
${ }_{17}$ Prosopografia é o estudo da carreira duma personagem através dos dados sobre ela contidos em inscrições e noutras fontes históricas.

${ }_{18}$ Assim designado por, no conjunto, envolver 20 pessoas. Assim, 10 estavam encarregados de julgar as contestações em matéria de estado civil, particularmente os casos reais ou pretensos de
} 
Depois desse estágio, tinha à sua frente um variado leque de opções, condicionado apenas pela idade, pela experiência e pela hierarquia existente entre as diversas funções:

- funções administrativas: o proconsulado ou o governo duma província, a prefeitura urbana (o mais alto cargo da carreira senatorial, obrigatoriamente confiado a um antigo cônsul), a prefeitura do erário militar...

- funções militares: a mais importante, a legacia duma legião, a que se juntava em certas circunstâncias o governo duma província;

- funções religiosas: mais por uma questão de prestígio, determinados cargos sacerdotais só podiam ser ocupados por senadores ou seus familiares; entre eles se recrutavam, por exemplo, os áugures, os pontífices, as vestais.

Mas o que importava sobremaneira - e condicionava mesmo o exercício doutras funções - era o acesso às magistraturas, exercidas durante um ano:

- a questura (o questor devia ter mais de 25 anos);

- o tribunado da plebe (magistratura que, pelas suas características, não era desempenhada pelos patrícios) ou a edilidade. A edilidade curul não era normalmente preenchida na época imperial; à edilidade plebeia só tinham acesso os plebeus;

- a pretura (o pretor devia ter mais de 30 anos; a pretura urbana era a mais importante);

- o consulado, magistratura suprema, a que só se podia aceder depois dos 33 anos. (Mesmo quando o currículo vem apresentado por ordem directa, o consulado surge à cabeça).

\section{Um exemplo}

No território actualmente português, não se encontraram até ao momento muitas inscrições com currículos senatoriais.

\footnotetext{
usurpação da cidadania romana - eram os decemviri stlitibus iudicandis; 3 tinham a seu cargo a superintendência da cunhagem da moeda de cobre, que era apanágio do Senado: tresviri monetales; 3 presidiam às execuções: os tresviri capitales; finalmente, 4 auxiliavam os edis na conservação das ruas de Roma: os quattuorviri viarum curandarum.
} 
Uma placa identificada na villa romana de Tourega, nos arredores de Évora, pode ser evocada a este propósito, ainda que exemplifique, no dealbar do século III, um caso de admissão tardia na carreira senatorial por parte de uma família que supomos oriunda dos notáveis eborenses. Na verdade, trata-se da memória mandada lavrar por Calpúrnia Sabina a seu marido e aos dois filhos (CIL II 112 = IRCP 382). Ele, Q(uintus) Iul(ius) Maximus, que vem identificado como c(larissimus) $v$ (ir) faleceu com 46 anos e, com essa idade, apenas acabara de ser designado pretor, depois de ter sido questor da província da Sicília, tribuno da plebe (era, pois, de origem plebeia, como é natural) e legado da província da Gália Narbonense, enquanto os filhos, Claro e Nepociano, falecidos com 21 e 20 anos (respectivamente), somente haviam ocupado o quadrunvirato viarum curandarum, referência só explicável por não terem logrado ir mais além.

Sirva-nos, pois, como exemplo, o texto CIL VIII 7049, que o próprio Cagnat apresenta:

$\mathrm{P} \cdot \mathrm{IVLIO} \cdot \mathrm{IVNIANO} \cdot \mathrm{MARTIALIANO} \cdot \mathrm{C} \cdot \mathrm{V}$

COS · QVAEST · PROVINCIAE · ASIAE · TRIB.

PLEBEI · PRAETORI · CVRATORI · CIVITATIS · CA

LENORVM · CVRATORI · VIARVM · CLODIAE ·

5 CASSIAE $\cdot$ ET $\cdot$ CIMINIAE $\cdot$ PRAEFECTO $\cdot$ AERARI $\cdot$ MILI

TARIS · PROCONSVLI · PROVINCIAE · MACEDONIAE ·

LEGATO · LEG III AVG · SEVERIANAE · ALEXANDRIANAE

PRAESIDI $\cdot$ ET $\cdot$ PATRONO $\cdot$ RES $\cdot$ PVBLICA $\cdot$ CIRTENSIVM $\cdot$ DE

CRETO $\cdot$ ORDINIS $\cdot$ DEDIT $\cdot$ DEDICAVITQVE

A homenagem foi prestada oficialmente pelos cidadãos de Cirte (respublica Cirtensium) ao seu governador e patrono, o senador (clarissimus vir) Públio Júlio Juniano Marcialiano, cujo currículo se revela a seguir, por ordem directa (encabeçado pela referência ao consulado):

- questor da província da Ásia

- tribuno da plebe (Marcialiano não era, portanto, de origem patrícia)

- pretor 
- curador da cidade dos Calenos

- curador das vias Clódia, Cássia e Cimínia

- prefeito do erário militar

- procônsul da província da Macedónia

- legado da III legião Augusta Severiana Alexandriana

- cônsul.

Uma carreira bastante regular, em que o exercício das magistraturas - mormente após a pretura - se intercala com funções administrativas e militares, numa ligação quase constante com a parte oriental do Império, apesar das idas periódicas junto do imperador, como recompensa pelos serviços prestados e para a necessária reciclagem.

É através da análise destes currículos de personagens, esquecidos a maior parte das vezes pelas fontes literárias, que se compreende o funcionamento miúdo da gigantesca máquina administrativa e militar do Império. Um estudo aliciante - base, como atrás se disse, das reconstituições prosopográficas.

\subsection{A carreira equestre}

Inscrito na lista oficial dos cavaleiros - cujo rendimento colectável não podia ser inferior a 400000 sestércios - o cavaleiro (vir egregius) tinha, no Alto Império, uma carreira mais ou menos assim estruturada: servia durante três anos em comandos militares de pequena importância. Era praefectus cohortis, praefectus alae, tribunus legionis.

Estas milícias serviam-lhe de estágio para os cargos administrativos e militares reservados à sua classe:

- as procuradorias, hierarquizadas consoante o vencimento anual ${ }^{19}$;

- as prefeituras: administrativas e militares; destas últimas, a ambição máxima do cavaleiro era a prefeitura do pretório, pela importância que detinha junto do imperador.

19 Sexagenarii (60 000 sestércios), centenarii (100 000), ducenarii (200 000) e trecenarii (300 000). 
Também havia funções religiosas exclusivas dos cavaleiros: podiam ser arúspices, organizadores das Lupercais...

Num epitáfio de Idanha-a-Velha ${ }^{20}$, memora-se L. Márcio Avito, filho de Fusco, da tribo Quirina, que faleceu no início da sua carreira como cavaleiro. Após ter sido praefectus fabrum, ocupou sucessivamente os seguintes postos:

- praefectus cohortis I Surorum Sagittariorum

- tribunus militum legionis X Fretensis

- praefectus equitum alae I singularium C(ivium) R(omanorum).

Num outro texto da Península (CIL II 4239), a província da Hispânia Citerior presta homenagem a um dos seus flâmines, M. Pórcio Narbonense. Além de flâmine "dos divinos Augustos", desempenhara também exclusivamente funções militares:

- tribunus militum leg(ionis) XXII

- praefectus alae Thrac(um) Herclan(orum)

- praefectus orae maritumae.

O maior cursus honorum equestre até hoje encontrado em Portugal refere-se a Caius Iulius Celsus, que chegou a ser admitido na ordem senatorial por adlectio do imperador. Está num monumento, bastante deteriorado, do Museu Arqueológico de S. Miguel de Odrinhas (Sintra) e foi o Prof. Scarlat Lambrino quem o logrou reconstituir na sua quase totalidade ${ }^{21}$. Assim, sabe-se que começou por exercer funções remuneradas com 60000 sestércios: curator viarum Aemiliae et Triumphalis e procurator XX (vigesimae) hereditatium per provincias Narbonensem et Aquitanicam 22; de 100000 sestércios desempenhou, entre outras, a função de procurador de Nápoles e do Mausoléu de Alexandria; foi procurador da Lusitânia, função que lhe rendia 200000 sestércios; e, ao que

\footnotetext{
20 Vide O Arqueólogo Português, nova série, III, 1956, p. 27-30.

${ }^{21}$ In Bulletin des Études Portugaises XVI, 1952, p. 145.

${ }^{22}$ A vigesima hereditatium era o imposto de 5\% sobre as heranças, que revertia a favor do erário militar.
} 
parece, a última função identificada na pedra é palatina, exercida junto ao imperador: procurator a libellis et a censibus (dos requerimentos e dos registos).

\subsection{Outros currículos}

Além do currículo do senador e do cavaleiro, outros podem ocorrer que abranjam toda a gama de funções subalternas, no exército e na administração. Também obedeciam a regras, ainda hoje não definidas por completo.

Porque surgem em muitas inscrições provinciais e porque servem frequentemente de trampolim para outros voos curriculares, interessa fixar cargos relativos à administração municipal: a edilidade, a questura (não confundir com a correspondente função senatorial) e o duunvirato, geralmente ocupados nesta sequência.

A ordo decurionum - ordem dos decuriões - formada pelos antigos magistrados, superintendia na vida municipal: daí que muitas inscrições oficiais tragam, no fim, D(ecreto) D(ecurionum), "por decreto dos decuriões".

Ser sacerdote imperial, flamen, representava, pelo prestígio que conferia, a maior ambição da burguesia municipal.

O ingresso no currículo equestre por parte dos magistrados municipais fazia-se, em regra, através do cargo militar de prefeito dos artífices (praefectus fabrum). Considera-se também muito provável que o acesso à carreira equestre - na sua vertente mais militar que administrativa, ou seja, para quem provinha de uma carreira militar - se processasse através da nomeação como primipilus, isto é, o centurião que comandava a $1^{a}$ a centúria da $1^{\text {a }}$ coorte numa legião.

Um outro cargo que vem mencionado frequentemente nas inscrições é o dos seviri Augustales, colégio formado essencialmente por seis libertos e ligado ao culto imperial. Os augustais constituíam um escol, dispondo de amplos meios financeiros.

A inscrição CIL II 49 = IRCP 236, da região de Beja, pode ilustrar o que fica dito: 


$$
\begin{aligned}
& \mathrm{M} \cdot \text { AVRELIO } \cdot \mathrm{C} \cdot \mathrm{F} \\
& \text { GAL } \cdot \text { IIVIR } \cdot \text { FLAMIN } \\
& \text { TI } \cdot \text { CAESARIS } \cdot \text { AVG } \\
& \text { PRAEFEC } \cdot \text { FABR }
\end{aligned}
$$

$\mathrm{D} \cdot \mathrm{D}$

$\mathrm{M}($ arco $) \cdot \mathrm{AVRELIO} \cdot \mathrm{C}($ aii) $\cdot \mathrm{F}($ ilio $) / \mathrm{GAL}$ (eria tribu) IIVIR(o) (duumviro) · FLAMIN[I] / TI(berii) CAESARIS AVG(usti) / PRAEFEC(to) · FABR(um) / 5 $\mathrm{D}($ ecreto $) \cdot \mathrm{D}$ (ecurionum)

"A Marco Aurélio, filho de Gaio, da tribo Galéria, duúnviro, flâmine de Tibério César Augusto, prefeito dos artífices - por decreto dos decuriões".

Um texto datável do reinado do imperador Tibério (14-37), pois que o homenageado fora eleito sacerdote do culto em honra deste imperador. Note-se, aliás, que Marco Aurélio ainda não tem cognomen, dado que estamos mesmo nos inícios do Império. Cidadão de Beja (Pax Iulia), pois está inscrito na tribo Galéria, que é a daquela cidade, foi duúnviro, flâmine e é homenageado pelos seus concidadãos quando se prepara para entrar na carreira equestre e, mui provavelmente, partir para outra região, para junto de um magistrado de quem vai ser o lugar-tenente, que essa era a função da prefeitura dos artífices, introduzindo-se assim na orgânica administrativa imperial.

\section{A IDENTIFICAÇÃO DOS IMPERADORES}

O nome dos imperadores surge frequentemente nas inscrições. Dum modo geral, consta dos seguintes elementos:

- o praenomen: $\operatorname{IMP}($ erator $)$

- o nomen: CAESAR

- os cognomes: pessoais, hereditários - AVG(ustus) - e honoríficos (ligados, por exemplo, a campanhas militares). 
Juntam-se ao nome os títulos:

- religiosos: PONT(ifex) MAX(imus)

- politicos: a) POT(estas) TRIB(unicia), cujo número nos indica geralmente o ano de reinado do imperador, porque é renovado anualmente (depois de Trajano, sempre a 10 de Dezembro);

b) Imperator: aclamação pelas tropas;

c) Consul

d) Censor, proconsul

- bonorificos: $\mathrm{P}$ (ater) $\mathrm{P}$ (atriae).

O manual de Cagnat (p. 177-259) é a obra mais acessível para informar da cronologia dos diversos títulos dados a cada imperador, na medida em que é através da sua menção ou omissão que nos é possível datar uma inscrição.

Indica-se, adiante, a designação epigráfica usual dos imperadores mais citados.

\section{Exemplos}

A - CIL II 4797, miliário encontrado junto a Vila Real:

$$
\begin{aligned}
& \text { IMP } \cdot \text { CAES } \cdot \text { NERVA } \cdot \text { TRA } \\
& \text { IANVS } \cdot \text { AVG } \cdot \text { GERM } \cdot \text { PONT } \\
& \text { MAXIMVS } \cdot \text { TRIB } \cdot \text { POT } \cdot \text { VII } \cdot \text { IMP } \\
& \text { IIII } \cdot \text { COS } \cdot \mathrm{V} \cdot \mathrm{P} \cdot \mathrm{P}
\end{aligned}
$$

IMP(erator) · CAES(ar) · NERVA · TRA/IANVS · AVG(ustus) GERM(anicus) · PONT(ifex) / MAXIMVS · TRIB(unicia) · POT(estate) · VII · (septima) · $\mathrm{IMP}($ erator $) / \mathrm{IIII}($ quartum $) \cdot \mathrm{CO}(n) \mathrm{S}($ ul $) \cdot \mathrm{V}($ quintum $) \cdot \mathrm{P}($ ater $) \cdot \mathrm{P}($ atriae $)$

"O imperador César Nerva Trajano Augusto Germânico, pontífice máximo, no $7^{\circ}$ poder tribunício, quatro vezes saudado imperador, cinco vezes cônsul, pai da Pátria”. 
Trata-se, portanto, de uma referência a Trajano, filho adoptivo de Nerva, que reinou de 97 a 117. Para a datação, interessa-nos sobretudo o consulado, o poder tribunício e a saudação imperial. Ora, Trajano

- foi cônsul pela quinta vez de Janeiro de 103 a Dezembro de 111;

- teve o 7ํㅜ poder tribunício de 10 de Dezembro de 102 a 9 de Dezembro de 103;

- foi saudado imperador pela $4^{\underline{a}}$ vez em 102 e pela $5^{\underline{a}}$ em 105.

Por conseguinte, o miliário data do ano 103, porque é o ano em que todos estes elementos são coincidentes. Falta aqui o cognome Dacicus, atribuído nos finais de 102; mas não admira que, na província, se desconhecesse ainda esse facto, quando o texto foi redigido.

B - CIL II 2107

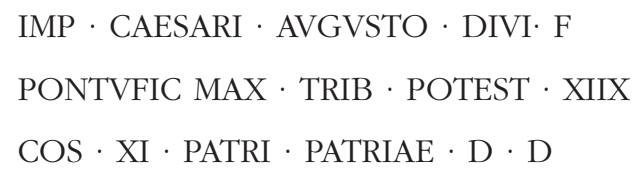

IMP(eratori) · CAESARI · AVGVSTO - DIVI · F(ilio) / PONTVFICI MAX(imo) - TRIB (unicia) · POTEST(ate) · XIIX (decima octava) / CO(n)S(uli) - XI (undecimum $) \cdot$ PATRI $\cdot$ PATRIAE $\mathrm{D}($ ecreto $) \cdot \mathrm{D}($ ecurionum $)$

Ao imperador César Augusto, filho do Divino, pontífice máximo, no seu $18^{\circ}$ poder tribunício, cônsul pela $11^{a}$ vez, pai da Pátria. Por decreto dos decuriões.

Esta inscrição, feita sem dúvida numa base de estátua, foi encontrada em Espanha, na província da Bética. Esta província foi criada por Augusto, mediante o desmembramento da antiga província da Hispânia Ulterior em Lusitânia e Bética.

A inscrição provém da pequena localidade de Arjona, que se desenvolveu no local do antigo município romano de Albense Urgavo, na região dos Túrdulos, nos limites da província Tarraconense (antiga Hispânia Citerior). Albense Urgavo, sita nas margens do rio Bétis (actual Guadalquibir), dependia da circunscrição judicial (conventus) de Córdoba. Como todos os aglomerados 
de cidadãos romanos, era administrada à maneira romana por magistrados, que não são aqui mencionados, e por uma assembleia, que desempenhava o papel do Senado em Roma, a assembleia dos decuriões. Foi essa assembleia que 118 tomou a iniciativa de erigir esta base em honra do imperador.

A inscrição vai permitir-nos estudar o nome, os títulos e os poderes de Augusto; servirá, além disso, para aprendermos a datar uma inscrição ou um documento de qualquer outro tipo, a partir dos títulos dum imperador.

O nome de Augusto inclui primeiramente o prenome imperator, que traduzimos por "imperador". Tratava-se, a princípio, do título honorífico dado, pelas aclamações do exército, aos generais que haviam alcançado uma grande vitória sobre o inimigo. Mas César, abandonando o seu prenome Caius, fez do título imperator o seu prenome; Augusto, seu filho adoptivo, imitou-o.

Vem depois Caesar: era o cognomen tradicional do ramo da família Júlia a que Júlio César pertencia; por conseguinte, Augusto herdou-o; mas, em vez de o conservar como cognomen, fez dele o seu nomen (gentilício), a partir do momento em que assumiu o cognomen "Augusto".

Este foi-lhe atribuído pelo Senado, sob proposta do fundador de Lyon, Lúcio Munácio Planco, aquando da sessão de 16 de Janeiro de 27 a. C., no decorrer da qual Octaviano abdicou dos cargos que lhe tinham sido outorgados durante as guerras civis do segundo triunvirato. Trata-se de um título bastante misterioso, todo ele impregnado de religiosidade, que deve ser posto em relação, por um lado, com o augurado (magistratura religiosa) e, por outro, com a auctoritas (autoridade), alicerce dos poderes de Augusto.

O nome termina com a filiação, que, no nome romano, geralmente se coloca a seguir ao nomen. Augusto é filho do divino, título de prestígio que mantém após ter sido ratificada a sua adopção por força do testamento de seu tio-avô, César, e depois da divinização deste último. Assim, "Gaio, filho de Gaio, Octávio" tornou-se, após a adopção, Caius Iulius Caesar, divi filius, Octavianus; e, em seguida, depois de 16 de Janeiro de 27, Imperator Caesar Augustus, divi filius.

Segue-se a menção à sua função religiosa essencial, o sumo pontificado. Chefe do colégio dos pontífices, velho colégio sacerdotal romano, o sumo pon- 
tífice era o chefe da religião romana. Foi a 6 de Março de 12 a. C. que o imperador revestiu este sacerdócio, depois da morte do seu antigo colega no triunvirato, Marcos Lépido. Na verdade, destituído e exilado devido à sua atitude hostil a Octaviano aquando da campanha final contra Sexto Pompeu, o Grande, em 36 a. C., Lépido conservara, no entanto, a função vitalícia de sumo pontífice, porque Octaviano, decidido a servir-se desse cargo em seguida, não quis desvalorizá-lo, o que aconteceria se tivesse forçado o seu legal titular a abandoná-lo. Foi, por exemplo, na sua qualidade de sumo pontífice que restaurou a antiga religião. Mas o sumo pontífice tinha de habitar na chamada regia sita no forum, de certo modo sob a protecção de Vesta, a deusa do lar da cidade; ora, Augusto não quis abandonar a sua casa do Palatino e, por isso, torneou a questão mandando dedicar, não longe dela, um altar a Vesta, a 28 de Abril do ano 12 a. C.

Por oposição ao imperium, fundamento do poder do príncipe fora de Roma, o poder tribunício, mencionado depois do sumo pontificado, fundamenta o seu poder na cidade. Patrício por via da sua adopção - que o fizera ingressar na família dos Iulii, uma das mais antigas e ilustres famílias patrícias de Roma, dado que se dizia descendente do troiano Eneias -, Augusto não podia ser tribuno da plebe; assumiu, portanto, os poderes de tribuno, mesmo sem deter esse título. Foi graças a esses poderes que se lhe outorgou a possibilidade de legislar; revestia-se, além disso, de carácter sacrossanto, apanágio dos tribunos da plebe, o que o tornava inviolável.

O poder tribunício foi-lhe atribuído vitaliciamente: tinha, contudo, de ser renovado todos os anos - circunstância que vai permitir-nos uma datação. Importa, porém, recordar que Augusto só começou a contar os seus poderes tribunícios a partir de Junho do ano 23 a. C., quando renunciou ao consulado anual. Desta sorte, o referido número do seu poder tribunício, o $18^{\circ}$, permite-nos datar a inscrição do período que medeia entre o final de Junho do ano 6 e o final de Junho de 5 a. C.

A referência ao consulado, a mais alta magistratura da Roma republicana, não detém, aqui, particular interesse do ponto de vista cronológico.

$\mathrm{Na}$ verdade, se Octaviano recebeu, ainda que ilegalmente, o seu primeiro consulado, em 43 a. C., com a idade de 19 anos; se posteriormente o assumiu 
regularmente desde 33 a 23 a. C. - o certo é que viria a abandoná-lo então, muito embora naturalmente o mantivesse nos seus títulos. Retomou-o apenas duas vezes mais - a 5 e a 2 a. C. - em honra dos filhos de Júlia e de Agripa,

Gaio e Lúcio César, seus netos pelo sangue e filhos por adopção. Apesar de tudo, a menção do consulado serve-nos para precisar aqui, um pouco mais, a data da inscrição: uma vez que o imperador assumiu o seu $12^{\circ}$ consulado a 1 de Janeiro do ano 5, o monumento é datável, portanto, do fim de Junho de 6 a. C. ao começo do ano seguinte.

O último título de Augusto mencionado nesta inscrição - pai da Pátria pode induzir em erro.

Prende-se este título com as mais antigas tradições romanas e remonta às origens lendárias da Cidade. Na realidade, fora Rómulo o "pai da Pátria" por excelência; mas deu-se o título, ao longo de toda a história da República, a homens que, por uma razão ou por outra, foram considerados "Salvadores da Pátria": atribuiu-se, por exemplo, a Camilo após a sua vitória sobre os Gauleses e a Cícero depois de reprimida a conjuração de Catilina. Augusto só o aceitou oficialmente a 5 de Fevereiro do ano 2 a. C. e, consequentemente, só a partir dessa data é que ele vai passar a integrar oficialmente os seus títulos. Tal proclamação mais não foi, porém, que a oficialização duma realidade: Augusto recusara, por diversas vezes, o título que o Senado e o povo de Roma lhe davam; todavia, nas províncias não se ligou importância a tais recusas - daí, a presença do título nesta inscrição. 


\section{OS MONUMENTOS E SUA IMPORTÂNCIA DOCUMENTAL}

Por facilidade didáctica, costumam dividir-se os textos epigráficos de acordo com o seu conteúdo:

- funerários: quando memoram defuntos;

- votivos: dedicados a divindades;

- honoríficos: quando homenageiam uma personagem;

- monumentais: destinados a figurar num monumento.

Há, contudo, textos simultaneamente funerários e votivos, funerários e honoríficos, honoríficos e monumentais, por exemplo.

\subsection{As inscrições funerárias ou a historiografia das pessoas}

\subsubsection{Em sintese}

As inscrições funerárias mais completas contêm os seguintes dados:

- consagração aos deuses Manes;

- identificação do defunto;

- idade com que morreu;

- identificação da(s) pessoa(s) que erigiram a memória, seguida de F(aciendum) C(uravit ou uraverunt) (mandou ou mandaram fazer);

- fórmula final: "aqui jaz» (H. S. E.) e o voto "que a terra te seja leve!» (S. T. T. L).

\subsubsection{O mundo da epigrafia funerária romana}

Poderá ser, eventualmente, bom ponto de partida para nos imiscuirmos um pouco mais no mundo subjacente a um monumento funerário romano epigrafado transcrever uma passagem do Satíricon de Petrónio, pese embora a sua extensão. 
A dado passo da sua lauta ceia, Trimalquião, liberto, rico armador, rodeado de amigos, volta-se para Habinnas, a quem já encomendara a construção do túmulo e dá-lhe ostensivamente ordens solenes, precisas, enfatuadas. Trata-se, não há dúvida, de uma criação literária; mas certamente Petrónio se terá inspirado em circunstâncias reais. E, como veremos, afinal, mutatis mutandis, utilizando outra escala, o que vamos encontrar não andará muito longe dessa presumível ficção.

Assim imaginou Petrónio, divertindo-se, sarcástico, o discurso de Trimalquião:

- Peço-te insistentemente que, aos pés da minha estátua, representes a minha cadelinha, coroas, perfumes e todos os combates de Petraites, para que, graças a ti, eu continue a viver depois da minha morte. Além disso, quero que haja cem pés de fachada, duzentos de profundidade. Quero também toda a espécie de árvores de fruto à volta das minhas cinzas e muitas vinhas. Com efeito, é um grande erro ter, em vida, uma casa bem fornecida e não se ocupar daquela onde teremos de habitar mais tempo. É por isso que, acima de tudo, quero que se acrescente: "Este monumento não faz parte da herança". Aliás, terei o cuidado, no meu testamento, de me pôr ao abrigo dos insultos, uma vez morto. Encarregarei um dos meus libertos de me guardar o túmulo, para que o público não vá descarregar as suas imundícies no meu monumento. Peço-te também que representes no meu monumento navios vogando de velas desfraldadas e eu próprio sentado num estrado, envergando a toga pretexta e com cinco anéis nos dedos, a distribuir ao público escudos que tiro de um saco. Sabes bem que dei um banquete público, com dois dinheiros por cabeça. Também podes pôr, se quiseres, as salas de jantar. E porás também todo o povo a embebedar-se. À minha direita, coloca a estátua da minha querida Fortunata, segurando uma pomba e que leve pela trela uma cadelinha; depois, o meu queridinho e ânforas de grande capacidade, seladas, para que o vinho não se entorne. Também podes esculpir uma urna partida, com um escravozinho a chorar em cima dela. Um relógio no meio, para que quem quer que veja as horas leia também, quer queira quer não, o meu nome. Quanto à inscrição, vê se esta te agrada: "Aqui jaz Caio 
Pompeio Trimalquião Mecenatiano. Foi eleito sêxviro na sua ausência. Embora pudesse pertencer a todas as decúrias, em Roma, não o quis. Escrupuloso, corajoso, fiel, partiu de pouco e deixou trinta milhões de sestércios... e nunca foi aluno dos filósofos. Descansa em paz - Tu também».

Não abundam na epigrafia da Lusitânia romana epitáfios em que se patenteie a frase, de teor jurídico, hoc monumentum heredem non sequetur, "este monumento não faz parte da herança" ${ }^{23}$. E se alguns dos motivos decorativos apontados se prendem com a actividade mercantil de Trimalquião, outros, como a pomba, já são mais correntes.

O mais importante é, porém, o nome: "Um relógio no meio, para que quem quer que veja as horas leia também, quer queira quer não, o meu nome” ... Essa, a função primordial do epitáfio; essa, a aspiração a que todo o mortal poderia aceder: "salvar o nome do esquecimento", para usarmos da feliz expressão do saudoso Gabriel Sanders. Gravar o nome faz parte do rito e incarna um mito também: a perenidade, "a vitória sobre a morte" (como já se teve ensejo de salientar), a imortalidade ansiada.

Cerrados os olhos do morto, importante era dar-lhe morada agradável, donde ele não saísse, por aí se sentir bem. A purificação ocuparia, por isso, papel primordial. Daí que as aras ostentem um jarro e uma pátera, objectos imprescindíveis nas abluções rituais. Eles aí estão, em fino baixo-relevo ou simplesmente gravados nos monumentos.

Perpetuados na pedra, quererão significar isso mesmo: perpetuidade. O acto purificatório não ocorreu apenas num instante: foi tornado perene ali. Ninguém ousará conspurcar o sepulcro... E ecoam, aqui, de novo, as palavras de Trimalquião: Para que o público não vá descarregar as suas imundícies no meu monumento.

Flores, sim, pode descarregar. Coroas, pétalas, grinaldas... Mas, pelo sim pelo não, o melhor é não confiar nos homens, nos sobreviventes - que a memória é

\footnotetext{
23 Cf., a este propósito, Rui Manuel de Figueiredo MARCOS, "Em torno do "Ius Sepulchri" romano - Alguns aspectos de epigrafia jurídica", Boletim da Faculdade de Direito da Universidade de Coimbra LXIII 1987 153-182.
} 
curta e a gratidão palavra de uso menor. Esculpam-se, pois, coroas, pétalas, grinaldas - imortalizadas na pedra, darão ao defunto a sensação de estar sempre em homenagem. O fóculo que algumas aras ostentam certamente nunca serviu para o fim previsto: recipiente das essências a queimar (foculus = pequeno fogo) em homenagem ao defunto, aquando do aniversário da morte, e simultaneamente aos seus deuses protectores; mas a sua presença perpetua a intenção.

Deuses protectores. Os Manes, divindades a quem, a partir de meados do século I da nossa era, os túmulos passaram a ser consagrados, mediante adequada cerimónia, de que se faz eco a fórmula D. M. S. = Dis Manibus Sacrum, abertura habitual dos epitáfios a partir de finais do século I da nossa era. Urgia que o local fosse doravante pertença dos deuses; que sobre os eventuais violadores recaísse a ira divina pelo sacrilégio cometido. Sintoma de que o espírito religioso começava a esfriar, ou, pelo menos, que os interesses económicos, de quando em vez, já estavam a falar mais alto, esta consagração aos Manes descansa, por outro lado, a consciência dos vivos: "ele" está em boas mãos.

Entre os mitos ligados ao mundo dos mortos, um se generalizou em todos os tempos, dado o fascínio que sempre a Lua exerceu sobre o Homem. Lua, morada dos mortos - como Franz Cumont lhe chamou ${ }^{24}$.

Auto-elogiou-se Trimalquião: "Escrupuloso, corajoso, fiel». O elogio é, porém, uma presença constante nas epígrafes, mormente a partir da segunda metade do século II. E, se exceptuarmos alguns, poucos, de cariz mais significante (desiderantissimus, amantissimus, carissimus...), os superlativos mais frequentes são piissimus ou pientissimus, "modelo de piedade". "Modelo de piedade", porquê? Porque a piedade, uma das mais importantes ideias morais e políticas dos Romanos, uma vez que abarcou todos os domínios desde o familiar ao social, ao religioso e ao político, como muito bem salientou Maria Helena da Rocha Pereira ${ }^{25}$, pode justamente constituir, por isso, um dos maiores elogios a alguém. E é de interesse dos vivos que o defunto se convença de que foi, de

\footnotetext{
${ }^{24}$ Franz CUMONT, Recherches sur le Symbolisme Funéraire des Romains, Paris, 1942 (reimp. 1966).

25 Maria Helena da Rocha PEREIRA, Estudos de História da Cultura Clássica. II.: Cultura Romana, Lisboa, 1984, 326-330.
} 
facto, "piedoso" e vai, por isso, continuar a sê-lo agora também, não infernizando o mundo dos vivos. Uma função apaziguadora, portanto.

O que nos interessava, todavia, era sublinhar a existência de um mito: o da relação íntima que continua a existir, mesmo para lá da morte, entre os dois mundos, o dos vivos e o dos mortos. A ausência de cronologia nos epitáfios, o uso da forma verbal no presente, a fórmula "que a terra te seja leve" consubstanciam toda uma ideologia mítica: o morto continua ali, ouve e pode falar com o transeunte. Daí, o final do epitáfio de Trimalquião: "Descansa em paz - Tu também". Daí o seu raciocínio, ao realçar o trabalho de Habinnas, o canteiro do seu futuro túmulo: “... para que, graças a ti, eu continue a viver depois da minha morte».

Há epitáfios que particularmente nos cativam pelo que simbolizam de ternura familiar e amorosa. Muitas vezes sem grandes alardes, com subentendidos até: "Aqui jaz Avintina. Viveu trinta e cinco anos. Pátroclo colocou à digna de merecimento. Que a terra te seja leve» (IRCP 41). Quem foi, na Quinta de Marim, há dois mil anos, Avintina e quem foi Pátroclo? Um casal? Hereniana, do mesmo local, viveu cinquenta e dois anos, dois meses e quatro dias, e, apesar desta especificação toda da idade, a denotar sofrimento e dor, o epitáfio omite pura e simplesmente quem o mandou fazer (IRCP 46). Cepião Semproniano faleceu com cinco anos; a sua cupa funerária, achada na Mexilhoeira Grande, foi mandada fazer pela avó, Pompeia Exoce (IRCP 65). Uma singela placa de quartzito vermelho, de formato irregular (IRCP 66), memora Gaio Júlio Arénio, Arbura, sua mulher, Júlia Amena, a filha - manteve-se anónimo quem lhes perpetuou a lembrança...

É, pois, neste mundo de nomes e de fórmulas que nos movimentamos. Hoje, como há vinte séculos atrás. Pompeia Exoce quase pertence ao nosso quotidiano, a família Arénia também. Sentimo-nos envoltos nessa atmosfera ritual, sacra, de mito quase magia, em comunhão. Pela força da palavra gravada. Pela eloquência sóbria da decoração. O espaço sagrado perdeu-se; deixou de ser um espaço determinado com "cem pés de fachada, duzentos de profundidade, [...] toda a espécie de árvores de fruto à volta das minhas cinzas e muitas vinhas" para abarcar o horizonte inteiro. Preferiam os Romanos que os seus mortos ficassem bem quietos, sob uma terra leve; o certo é que eles ficaram, sim, mas a sua memória não se apagou. 


\subsubsection{Uma inscrição funerária}

Exemplifiquemos um pouco mais as informações que uma epígrafe funerária nos pode dar, com os comentários a uma placa procedente da aldeia do Souto da Casa, no concelho do Fundão. O monumento tem 43,3 cm de altura e 92 de comprimento; destinava-se, pois, a ser colocado no frontispício dum jazigo de família, como, de resto, o próprio texto o declara:

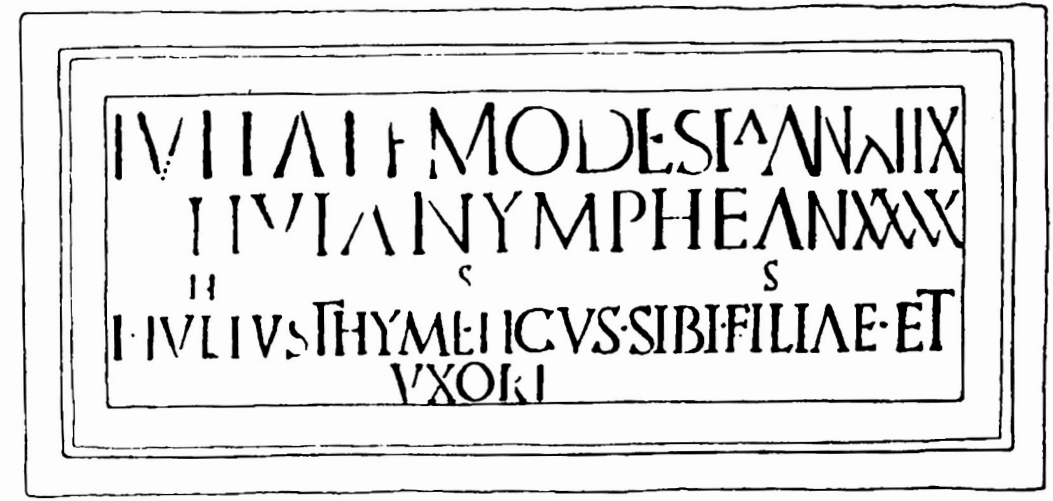

Desenho de José Luís Madeira

\section{IVLIA L F MODESTA AN XIIX \\ LIVIA NYMPHE AN XXXX}

H S S

L · IVLIVS THYMELICVS $\cdot$ SIBI $\cdot$ FILIAE $\cdot$ ET

VXORI

A paginação - com o recurso inteligente a letras grandes e pequenas - obedeceu à necessidade de logicamente se adequar o texto ao espaço disponível e o uso de siglas e de abreviaturas depende precisamente desse espaço, detém efeitos estéticos e - facto importante a realçar desde já - demonstra que a população compreendia perfeitamente o seu significado.

Nessa ordem de ideias, compete ao epigrafista, como primeira fase do seu trabalho, desdobrar siglas e abreviaturas, decifrar o texto: 
IVLIA L(ucii) F(ilia) MODESTA AN(norum) XIIX (duodeviginti)

LIVIA NYMPHE AN(norum) XXXX (quadraginta)

$\mathrm{H}($ ic $) \quad \mathrm{S}($ itae $) \quad \mathrm{S}($ unt $)$

L(ucius) $\cdot$ IVLIVS THYMELICVS $\cdot$ SIBI $\cdot$ FILIAE $\cdot$ ET

VXORI

Virá, em seguida, a tarefa da tradução. E, aqui, particular atenção se deve dar ao facto de não estarmos perante um texto literário ou a transcrição duma fala quotidiana. É um texto "lapidar", atribuindo ao adjectivo toda a sua conotação, real e figurada. Tentaremos, pois, uma tradução que não atraiçoe o conteúdo textual e lhe mantenha íntegras as suas características. Assim:

\author{
AQUI JAZEM \\ JÚlIA MODESTA, FILHA DE LÚCIO, DE 18 ANOS, \\ LÍVIA NINFA, DE 40 ANOS. \\ LÚCIO JÚLIO TIMÉLICO PARA SI, PARA A FILHA E \\ PARA A MULHER
}

Dentre os vários aspectos passíveis de análise foquemos, por agora, também como simples exemplificação, os dois seguintes:

\title{
A onomástica
}

Como é que se identificam as personagens desta família?

O pai usa os tria nomina: o praenomen, em sigla por ser muito frequente; o nomen ou gentilício, que é o nome de família que transmite à filha, Modesta; e o cognomen, que será, na verdade, o nome que realmente o distingue. Neste

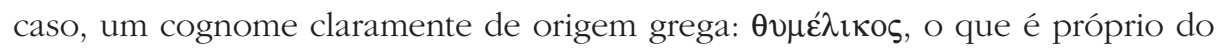
teatro, do coro. Um cognome de rara e indiscutível conotação cultural.

A mulher pertence, naturalmente, a uma outra família, a gens Livia, mas também ela apresenta um cognome grafado à grega, NYMPHE. Ora, sabendo nós que a adopção da onomástica grega é, normalmente, indício de um passado ser- 
vil, não andaremos certamente longe da verdade se afirmarmos que estamos perante uma família de libertos. Assim se poderá explicar também a circunstância de ser a filha quem, no epitáfio, está nomeada em primeiro lugar: é porque ela detinha já um estatuto jurídico que os pais muito se orgulhavam, era ingenua, de condição livre.

Raramente a literatura nos permitirá uma incursão assim, no seio da ternura da vida familiar imortalizada na pedra...

\section{A menção da idade}

Poderemos também interrogarmo-nos acerca da total ausência de cronologia. O epigrafista - pelo tipo de letra (paleografia) e pelo formulário - sabe que se trata de uma epígrafe datável da primeira metade do século I da nossa era; mas, para o cidadão comum, de então e de agora, o tempo parece ter parado. "Aqui jazem". Agora. Neste momento. Ainda. É a eternidade que se procura; é o tempo sustido, voluntariamente sustido.

E porquê dezoito grafado assim? Por evidentes imperativos de paginação: XVIII ocuparia muito mais espaço e não caberia ali. Mas essa forma vai permitir-nos explicar mais cabalmente como é que se diz dezoito em Latim: "dois de vinte", duodeviginti.

E morreu Ninfa com quarenta anos certos?

Essa é uma outra questão que apaixonou os epigrafistas e para a qual já hoje se tem uma explicação: o arredondamento da idade por lustros era prática corrente (tal como hoje nos acontece, no quotidiano, ao pretendermos dar uma idade aproximada). Ou porque se desconhecia a idade exacta e se contavam os censos quinquenais; ou porque, na verdade, que interessava, agora, a idade real?

Da jovem Modesta se escreveu com exactidão e adivinhamos a dor pungente de Timélico ao mandar lavrar o epitáfio dos seus dois entes queridos aos quais sobreviveu e aos quais, reza o texto, mesmo fisicamente vai querer, um dia, juntar-se...

De Ninfa sabemos que, mulher madura, morreu quando ainda muito haveria a esperar dela, do seu carinho, da sua ternura. 
Na verdade, estranhei, um dia, a relativa abundância de referências a falecimentos aos quarenta anos e dei uma vista de olhos às Inscripciones Latinas de la España Romana, de José Vives, na parte que respeita às inscrições funerárias.

Embora de uma forma empírica, é certo, sem o rigor das estatísticas - aliás, 129 impossíveis de fazer neste domínio -, a breve pesquisa efectuada levou-me a concluir serem relativamente numerosos os epitáfios romanos em que "quarenta anos" surgia como idade da morte, sendo que, a maior parte das vezes, aparece inclusive grafado com $4 \mathrm{X}$. Por vezes, até, com uma certa tendência para a colocação de pontos interliterais.

Dir-se-á que a frequência não é assim tão significativa. Contudo, a circunstância de também em epitáfios paleocristãos ser notória a ocorrência do "X aspado" - $\quad$ - para indicar a idade induziu-me a reflectir sobre o verdadeiro significado desse número.

Outros elementos, de ordem etnográfica, directamente ligados às mais diversas tradições religiosas começaram a apontar-me no mesmo sentido de ao número "quarenta" se dever atribuir um valor predominantemente simbólico.

$\mathrm{Na}$ verdade,

1. Depois de saírem do Egipto, em busca da Terra Prometida, erraram os Hebreus quarenta anos no deserto (Êxodo, 17, 35) e Moisés, antes de receber as tábuas com os Dez Mandamentos, "permaneceu junto do Senhor quarenta dias e quarenta noites, sem comer pão nem beber água" (Êxodo, 34, 28).

2. Jesus Cristo passará quarenta dias em oração no deserto (Lucas, 4, 2) - e, daí, ser de quarenta dias o período da Quaresma.

3. Não será, pois, de estranhar que o cânone $n^{\circ} 43$ do Concílio de Elvira determine que a festa do Pentecostes se celebre não no $40^{\circ}$ dia após a Páscoa, como estava a ser costume, mas no $50^{\circ}$, decerto para exorcizar o eventual carácter mágico que se estaria a atribuir já a este número.

4. Cedo se institucionalizou, por exemplo, a propósito de doenças, a prática de «estar de quarentena". 
5. Falando sobre este assunto com Nelly Vulkanova, da Universidade de Sófia, vim a saber que na Bulgária:

a) durante os primeiros 40 dias após o parto, a criança só pode ser vista pelos pais e pelos parentes mais próximos;

b) que, por morte de um ente querido, os parentes mais próximos, designadamente a viúva ou o viúvo, não podem sair durante quarenta dias e é no $40^{\circ}$ dia que se celebram os rituais de sufrágio.

6. Aliás, não se decretaram quarenta dias de luto por Hussein?

7. E, nos Contos das Mil e Uma Noites, não há a história de Ali Babá e dos... 40 ladrões?

8. Seja-me permitido referir, ainda, a inopinada verificação que recentemente me saltou aos olhos: Michael Bland, no livro Novo Manual de Relações Públicas (Editorial Presença, Lisboa, 1989, p. 42-43) escreve que "O chefe de redacção de um grande jornal britânico disse, certa vez, que não há nenhuma história que não possa ser contada em quarenta palavras”.

Desta sorte, a acrescentar ao que se tem escrito sobre a utilização, nos epitáfios romanos, do arredondamento das idades em múltiplos de cinco, haverá, porventura, a considerar que "morrer aos quarenta anos" significará, entre os Romanos, "ter vivido em plenitude" ou, como se escreveu em jeito de elogio num epitáfio célebre: "Vivió según su edad”.

E ocorreria perguntar: nesse caso, não assumirá "oitenta" também um valor simbólico?

\subsection{A epigrafia religiosa}

\subsubsection{Em sintese}

Também as inscrições votivas têm um esquema habitual:

- nome da divindade (em dativo) acompanhado de S(acrum), consagrado;

- identificação do dedicante; 
- motivo da dedicatória (ex voto, ex iussu, pro salutem);

- fórmula final consecratória: A. L. V. S., A. L. P., V. S. L. M. ou equivalente.

\subsubsection{Um ex-voto}

Para exemplo de uma epígrafe votiva, ou seja, do ex-voto a uma divindade, escolhi um altar procedente de Póvoa da Atalaia, concelho do Fundão, que se encontra exposto no Museu Municipal Dr. Santos Rocha, da Figueira da Foz, em cujo inventário detém o nº 8640.

Foi, de resto, dado logo a conhecer pelo fundador do museu no volume I, n ${ }^{\circ}$ 8, 1908, p. 217-218, do Boletim da Sociedade Archeologica Santos Rocha, embora, na verdade, não seja muito citado na bibliografia sobre as manifestações religiosas da Lusitânia. Tive ensejo de, num breve trecho sobre a importância daquele museu, novamente o referir ${ }^{26}$ também com a intenção de mais o divulgar.

Não vamos ater-nos a aspectos históricos, que não é aqui ocasião. Refira-se, apenas, que, numa análise de índole histórica, teríamos que interrogarmo-nos sobre o porquê do ex-voto; se o culto à deusa Vitória é vulgar ou inusitado na região; em que categoria social se há-de incluir o dedicante, Curius Privatus. Interessar-nos-ia muito descobrir qual terá sido o contexto arqueológico do achado, com o fim de, por essa via, podermos eventualmente chegar ao contexto original do monumento ao tempo dos Romanos. Adivinhamo-lo, porém: é altar a ser posto em lugar oficial de culto.

E, antes de entrarmos na análise meramente textual, talvez interesse reflectir, ainda que por breves instantes, sobre a tipologia do monumento. É que ele apresenta, no capitel, um fóculo bem delineado. A função do fóculo era a de receber as essências que o devoto ali queimaria em honra da divindade (foculus = pequeno fogo). Ora, a "imortalização" do fóculo pretende perpetuar uma intenção (já o referimos em relação aos altares funerários): o dedicante poderá

\footnotetext{
${ }^{26}$ In Conimbriga 32-33, 1993-1994, p. 299 e 301, foto 2.
} 


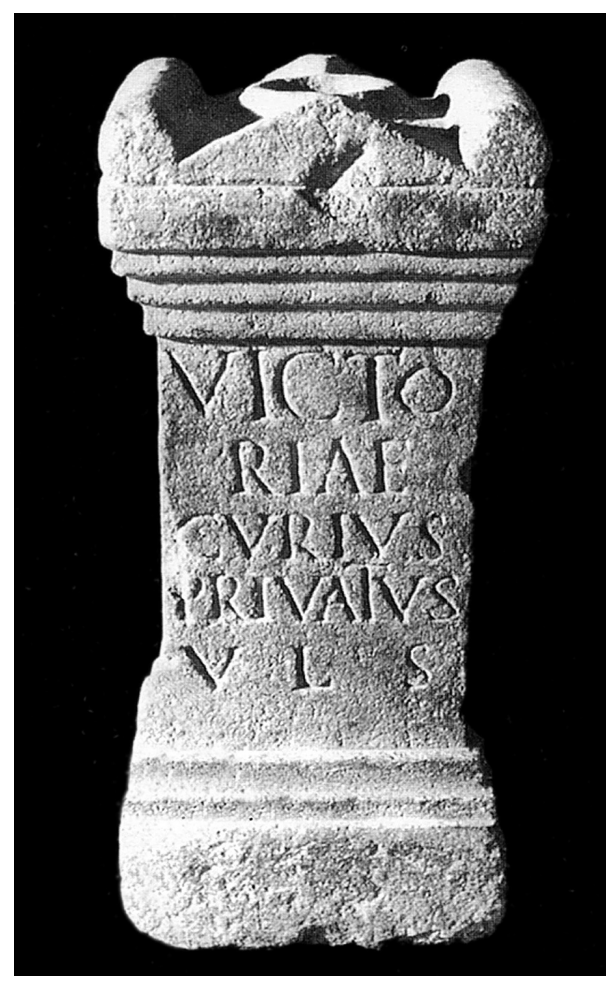

olvidar a oferenda; ser-lhe-á, de resto, impossível manter um fogo sagrado aí - mas a intenção lá está e isso, perante a divindade, é o que mais importa.

\section{Um texto elucidativo}

Com efeito, o monumento consubstancia a oferta resultante dum compromisso assumido: Cúrio Privado votum libens solvit, "cumpriu o voto de livre vontade". A fórmula vem em siglas por ser corrente; mas talvez não seja despiciendo analisarmos o seu significado profundo.

Primeiro, trata-se de um votum. Voto é "desejo", "aspiração"; ex-voto é, etimologicamente, desejo que deixou de ser; "deixou de ser", porque se concretizou. Ou seja, o dedicante expôs um desejo à divindade, comprometendo-se a erigir-lhe um altar em acção de graças; a divindade acedeu à sua prece; e o dedicante cumpriu o prometido: votum solvit. Não deixa de ser sintomático o verbo escolhido, solvere, que à letra significa, como se sabe, "dissolver". Portanto, o compromisso desaparece com o acto de erigir o altar.

Mas - e este será o segundo aspecto a referir - não é um cumprimento qualquer, não: trata-se de um acto que assume características do foro jurídico quase, porquanto expressamente se indica que se pratica libens, "de livre vontade", sem constrangimentos de espécie alguma. Um particípio presente de significado preciso, que empresta toda a força ao gesto do dedicante - que, se fora constrangido, a sua acção ficava desprovida de sentido e, até, de validade.

Importa, finalmente, perguntar: Victoriae é dativo ou genitivo de posse? 
O facto de encimar o texto pode ser indício de que o local sagrado onde se depositou não seria da veneração exclusiva desta divindade. É provável que tal haja acontecido, como, ainda hoje, mesmo num santuário célebre, há altares laterais doutras invocações.

Mas, realmente, poder-se-á entender quer como dativo - a oferta de Cúrio Privado a Vitória - quer como genitivo de posse: o monumento é da deusa Vitória, em resultado da oferta feita. Penso, aliás, que a ambiguidade é propositada, como noutros casos acontece. Cada qual interprete como achar melhor.

Pela paleografia e pelo tipo de molduração, é monumento datável da segunda metade do século I da nossa era. No entanto, como já tive ocasião de referir, para os Romanos, aqui, os dados cronológicos tinham mesmo de estar ausentes: pretendia-se que a oferta fosse... eterna. E quase poderíamos afirmar que boa parte da intenção se logrou concretizar, porque, dois mil anos passados, cá estamos a falar do gesto dum devoto desconhecido Cúrio Privado, que, doutra sorte, nem teria entrado na História!...

\subsubsection{O sexo dos deuses romanos}

Ficou tão célebre, em Bizâncio, a polémica levantada acerca do sexo dos anjos que, ainda hoje, questões aparentemente supérfluas se apelidam de 'bizantinices' e a uma discussão de nulo interesse científico ou de nenhum resultado prático se aplica a expressão "discutir o sexo dos anjos".

Bem vistas as coisas, porém, o tema do sexo atribuído às divindades poderá ter, hoje, alguma relevância, na medida em que todos sabemos que as entidades divinas são, antes de mais, criações do espírito do Homem. E se os teólogos hão-de interrogar-se sobre a essência divina, aos epigrafistas - que lidam com as inscrições onde esses nomes aparecem, ora no masculino, ora no feminino, ora de uma forma em que se não descortina bem se são masculinas ou femininas - a questão, nos nossos dias, poderá não parecer de todo despicienda, pelas implicações que tem a nível das mentalidades, por exemplo. 
Por outro lado, afigura-se-me que, imbuídos como estamos, neste mundo ocidental em que vivemos, dos dogmas cristãos e católicos, houve questões que certamente nunca nos pusemos de modo sistemático, sob pena de sermos acusados de heréticos.

Assim, a visão habitual da Santíssima Trindade, três pessoas divinas numa só: o Pai 'gera' o Filho e, amando-Se, o Seu amor concretiza-se na terceira pessoa, o Divino Espírito Santo. É um dogma - inacessível, portanto, nos seus contornos profundos, à mente humana. Aos teólogos competirá uma explicação plausível, na sua terminologia; aos que lidamos com os homens e o seu universo mental cumpre-nos interrogar-nos: não há, nesta visão, uma simbiose de masculino e de feminino, apesar de sempre tudo nos haver sido apresentado no masculino? Não encararia, aqui, a hipótese de estarmos perante o resultado de um pensamento elaborado fundamentalmente por homens; creio que não é de ir por aí. Agora, o que pode obrigar-nos a reflectir é justamente este enleio de masculino-feminino em que o dogma se envolve, de facto.

Certamente que a questão nunca foi - que eu o saiba - escalpelizada ou trazida à 'praça pública', nem dela os católicos precisavam, porque, para além do culto dos Santos, homens e mulheres de carne e osso como nós, o lado feminino da 'divindade' é francamente assumido pela presença constante de Nossa Senhora. E a vinda de Jesus Cristo à Terra materializou, no masculino, uma das pessoas da Santíssima Trindade à nossa dimensão, inclusive no nascimento a partir de um ventre materno.

\subsubsection{1 "El Sexo Divino", de Sabino Perea}

Vêm estas considerações a propósito da publicação (Alderabán Ediciones, Madrid, 1999) do livro El Sexo Divino, que traz como subtítulo Dioses hermafroditas, bisexuales y travestidos en la Antigüedad clásica. É seu autor Sabino Perea Yébenes, docente de História Antiga na Universidad Complutense de Madrid.

Escrito no ano de 1998, em Madrid, Sevilha e Marraquexe, consta de 240 páginas com 52 brevíssimos "capítulos", quase em jeito de 'entrada' para um 
dicionário (incluindo a introdução onde se discutem conceitos e o final), a que acrescem 13 páginas de actualizada bibliografia sobre o tema, destinada a quem, sobre o assunto, deseje adquirir conhecimentos mais aprofundados ${ }^{27}$.

Trata-se, no fundo, de uma 'viagem' ligeira - acompanhada de ilustrações comprovativas, antigas e modernas, e apoiada fundamentalmente em fontes literárias - uma viagem pelo mundo dos mitos, desde Aristófanes e o mito dos "corpos duplos" n' O Banquete de Platão até, precisamente, Cristo homem, passando, obviamente, por Diónisos, Adónis, Afrodite/Vénus, Narciso, Fénix, Heliogábalo, a Fortuna Viril, a hiena, Adão e Eva, entre muitos outros, sem esquecer "a dualidade e androginia de Deus nos Evangelhos gnósticos e as cartas”.

Salvaguarda o autor, logo nas primeiras linhas, uma leitura aprioristicamente lasciva e define, de imediato, a tónica do seu trabalho, ao salientar que "o leitor não encontrará aqui uma galeria de relatos literários eróticos em que os deuses greco-romanos se comportem como 'loucas' e onde as deusas amem e guerreiem como legionários" (p. 11). Rejeitando in limine qualquer "opção ética ou biológica para os homens e mulheres do nosso tempo", afirma ser sua intenção proporcionar uma reflexão sobre a androginia e a sexualidade de um ponto de

vista religioso, ou seja, com base no que a razão humana alcança ou não, ainda que não possa resistir «ao fascínio do paradoxo de um mysterium tremendum" (ibidem).

$\mathrm{Na}$ verdade, que pensar perante o grupo escultórico procedente de Pompeios (fig. 17, p. 137) em que se representa Hércules e Ônfale, mas o herói se encontra "vestido com traje feminino transparente" e "Ônfale com as armas do herói»? Uma simples 'brincadeira' do escultor? Não. É a representação plástica da passagem da 'vida' do musculado herói em que, durante três anos, fica escravo da rainha da Lídia, sendo obrigado a executar para ela as tarefas mais hediondas. Presos nas malhas do Amor, permitem-se os 'jogos' mais invulgarmente sedutores, como rezam os textos antigos: "Ônfale enverga a pele de leão do

\footnotetext{
27 Não é possível referir, ainda que mui fugazmente, alguns dos trabalhos citados. Que me seja permitido, porém, chamar a atenção para o curioso título dado por G. Cloke a um dos seus livros: This Female Man of God (Londres, 1994).
} 
herói e brande a sua maça, enquanto o herói se veste de mulher, com um vestido de linho transparente, passando bons bocados aos pés da rainha, a fiar um manto" (p. 136, com indicação das fontes literárias) - episódio que foi, amiúde, gozado pelos escritores romanos do Império como exemplo de "ridícula submissão sexual".

Não são, porém, essas mitologias que interessam para o tema que me propus abordar.

Afigura-se-me particularmente significativo o capítulo 32, sobre os Numina (p. 149-153). Começa por citar P. Boyancé ${ }^{28}$, segundo o qual a fórmula sive deus sive dea - "seja deus ou seja deusa" - que surge, de vez em quando, nos textos epigráficos, não implica a ideia de que os Romanos considerassem os numina como seres sem sexo:

«Tout au contraire, dans sa prudence, le Romain, quand il n'est pas fixé à ce sujet, envisage les deux hypothèses possibles".

Sabino Perea interpreta-o, porém, doutra forma:

"Ambas al mismo tiempo, es decir, se referian al andrógino" (p. 149) 29.

Continuando, de resto, nessa ordem de ideias, o Autor levanta a seguinte hipótese:

«Es posible pensar que cuando una divinidad indígena hispana y otra romana se fusionan asistimos a un nuevo ente divino. Ambas personas redefinen sus competencias, sus formas, y como toda divinidad in origine es posible la alusión a su bisexualidad denotada en las partículas deus sive dea o bien deus deave".

Acrescenta Sabino Perea - e aqui, parece-me, há que ter, porém, alguma cautela - que esse pode ser, inclusive, um índice cronológico a ter em conta,

\footnotetext{
28 Études sur la Religion Romaine, Roma, 1972.

29 Sobre este tema específico escreveu Sabino Perea o artigo "Las fórmulas epigráficas deus deave, si deus si dea y diis deabusque", Veleia 151998 167-180.
} 
dado que o achamento de inscrições com estas fórmulas indicará, em seu entender, "precisamente o momento de implantação de deuses romanos e/ou a sua fusão com outros, dotados, ou não, de nome, do panteão indígena”. E digo que há-de ter-se cautela, não só porque isso implica, antes de mais, a atribuição de uma cronologia ao monumento epigráfico, o que nem sempre é fácil, como se sabe, mas também porque essa conceptualização poderá também evidenciar uma cultura que não será, certamente, apreendida nos primórdios do contacto entre indígenas e romanos no seu quotidiano.

Importante me parece, num outro registo, a relevância dada ao facto de os Romanos, "pueblo de agricultores", terem como "sus dioses más íntimos" as "divinidades de los campos, que habitaban o dominaban las fuerzas telúricas, que dirigían las germinaciones, que limitaban las fincas cultivadas, que habitaban los bosques" (p. 151). Apesar de serem "fuerzas incógnitas", "muchas veces sin nombre, sin formas siquiera" "estaban ahi, y era preciso tenerlas en cuenta, consultarlas, no ofenderlas, comunicarse con ellas ritualmente" (ibidem).

Por isso, continua Sabino Perea - e a essa atitude já eu próprio por várias vezes me tenho referido ${ }^{30}$-, quando, por exemplo, se arrasava um bosque para o transformar em terra de cultivo, ou seja, para "inseminá-lo" (usando um termo rigorosamente exacto mas que, na linguagem quotidiana, se aplica apenas a seres vivos) ${ }^{31}$, "era preciso advertir a la divinidad que lo habitaba del acto, y hacerle una primicia de sangre, para expiar la ofensa de haber ollado una tierra divina, ahora sagrada, com/partida, con/sagrada” (p. 152).

Daí que, por exemplo, haja desdobramentos - Liber e Libera:

\footnotetext{
30 Considero que a ara dedicada Triborunni por T. Curiatius Rufinus, identificada na villa romana de Freiria (S. Domingos de Rana, Cascais) nada mais é do que o 'pedido de licença' de um colono recém-chegado à divindade indígena que presidia a esses campos para neles se poder instalar e os explorar (cf. FE 59 = AE 1985 514). Da mesma forma, o pedestal erigido, em Amares, no conventus Bracarangustanus, por Q. Sabinius Florus, seguramente colono também, a um Génio indeterminado (vide: Encarnação, José d', "O culto ao Génio no Noroeste peninsular", Cadernos de Arqueologia série II 21985 41-49 = Année Philologique 198710.364 = HEp 11989 663), nada mais é do que reflexo dessa necessidade intrínseca de apaziguar a divindade protectora do local, o Genius Loci.

31 É curioso verificar que o Dicionário da Língua Portuguesa, de Cândido de Figueiredo, explicita que "inseminação" é uma "antiga prática supersticiosa, que consistia em revolver a terra e lançar nela qualquer coisa tirada de um lugar onde havia doença, e semear ali uma planta, que serviria para a cura da mesma doençan.
} 
«No son dos divinidades - explica Sabino Perea - sino una divinidad de sexo doble, con dos naturalezas, que encierran la terrible paradoja de encarnar la suma fertilidad y, al mismo tiempo, ser parejas esteriles" (ibidem).

Daí que, por coerência, o Júpiter que presidia à delimitação dos campos, Iuppiter Terminalis, ou o deus Terminus apresentassem os símbolos dos dois sexos.

Não deixará igualmente de ser sintomático verificar que, de acordo com as investigações levadas a cabo por Sabino Perea, apenas a deusa Fortuna era adorada dentro dos estabelecimentos balneares dos acampamentos romanos: uma divindade feminina a monopolizar "el culto en un ámbito cerrado y exclusivamente masculino cual es el aseo de los soldados" (p. 156).

A concluir, a - hoje imprescindível - tónica profundamente humanística: os mitos greco-romanos, afinal, nada mais são do que a forma escolhida para se "fijar literariamente un subconsciente colectivo conflictivo, primitivo, que sólo hoy día, muchos siglos después, se empieza a comprender a la luz del psiconanálisis y la etnopsiquiatría” (p. 239), pois, na verdade, cada uma dessas personagens representa, de certo modo, "una epopea introspectiva que busca y rebusca en el sexo y la sexualidad latente un viaje necesario en pos de la comprensión del propio espíritu y espiritualidade» (p. 240).

\subsubsection{Um debate para a aculturação}

Contudo, se Sabino Perea termina o seu interessante excurso com a afirmação de que esta se lhe afigura "mensaje actual y útil para las gentes de nostro tiempo" (p. 249), não é menos certo que a sua contribuição resulta bem significativa se a aplicarmos a alguns casos da teogonia peninsular que mereceram comentário nos últimos anos, envoltos, quiçá, ali e acolá, dalguma hesitação e controvérsia.

E estou crente que essa aplicação a casos concretos das conclusões acima referidas pode vir trazer nova luz - ou, pelo menos, mais luz - a algumas dessas considerações. 


\section{a) $\mathrm{O}$ "deus" Tutela}

Poderemos começar por Tutela.

O nome é claramente feminino, tanto em Latim como nas demais línguas latinas. Sucede, porém, que Manuel Menor Currás, ao estudar uma ara achada em território galego, mais concretamente em San Vicente de Coucieiro (Paderne), dedicada a esta divindade, que aí apresenta o epíteto (em dativo) Berisi, titula assim o artigo: "Otra ara al dios Tutela" 32 .

Explicitando que se trata da divindade protectora de «un grupo o subgrupo étnico (¿centuria?), en este caso los BERISI»(p. 308), Manuel Menor sublinha que "esta divinidad es la que se conocía en el mundo greco-latino más comúnmente como Tyché-Fortuna, y a ella se asimilan los BANDUA tan frecuentes del Noroeste peninsular (...) tal como confirma la representación de la pátera de "Bandua-Araugelensis" de la Colección Calzadilla de Badajoz" (p. 307).

Sobre o carácter masculino ou feminino da divindade nem sequer se põe a questão, optando claramente, sem porém o explicar, pelo sexo masculino. Aliás, se formos a um dicionário de Latim, fácil é que tenhamos, sobre esse termo, a indicação de que se trata do "génio protector dum lugar". E, nos índices de CIL II (p. 1130), são referidas três epígrafes (3021, 3377 e 4091) dedicadas "deus Tutelae» [sic]; contudo, se CIL II 4055 alude a um Pantheus Tutela - continuamos a ver o referido índice - o certo é que, nas inscrições 3349 e 4056, a forma que aparece é Tutela Augusta.

\section{b) "Transformação de ideias"}

Por ocasião do VIII Coloquio Internacional sobre Lenguas y Culturas Prerromanas de la Península Ibérica (Salamanca, 1999), apresentou o Prof. Francisco Marco Simón uma notável síntese sobre a aculturação religiosa. Deu-lhe primeiro o título, que assim aparece no programa, de "La transformación de las ideas religiosas en la Hispania indoeuropean; preferiu, depois, a fórmula

\footnotetext{
32 Boletín Auriense 91979 305-310.
} 
"Imagen divina y transformación de las ideas religiosas en el ámbito hispanogalo" e assim vem nas $\operatorname{actas}^{33}$.

Ora, precisamente um dos primeiros casos sobre que Francisco Marco se debruça é o da representação de Bandua Araugelensis. E verbera "los estudiosos que se han referido a esta espléndida pieza" por terem "cometido, por lo general, el error de considerar divinidad femenina a Bandua, cuando sus epítetos presentan como un dios inequívocamente masculino; dicho error puede explicarse a partir de la consideración de la figura de nuestro plato como una Dea Fortuna con los atributos de la Tyché helenística". Isso resulta apenas, segundo Francisco Marco, do facto de a «iconografía clasicista característica de la femenina Tyché" ser muito semelhante à dos Genii Loci, categoria divina em que se insere Bandua (p. 215).

Atendendo a que o objectivo do autor era mostrar, através de exemplos concretos que "la imagen es un medio de espresión al que puede tener acceso el fiel más humilde, mientras la escritura exige un conocimiento de la lengua y de las fórmulas cultuales difícilmente adquirible fuera de un cierto estatuto social» (p. 214), o caso da diferença de sexos não é desenvolvido para além do que atrás se disse.

\section{c) Arentius - Arentia}

Em recente e extenso artigo onde - em jeito de síntese das reflexões que tem vindo a fazer sobre os Lusitanos - Jorge de Alarcão lança "novas perspectivas" sobre este povo "(e outros mundos)»34, vem uma referência expressa a Arentius e a Arentia, que o Autor considera constituírem "obviamente, um par divino": Arentius tem "a sua paredra (ou Arentia o seu paredro)" (p. 304).

E acrescenta, mais adiante, que "eram divindades guerreiras".

33 VILLAR (Francisco) y FERNÁNDEZ ÁLVAREZ (Mํa Pilar) (Eds.), Religión, Lengua y Cultura Prerromanas de Hispania, Ediciones Universidad de Salamanca, 2001, p. 213-225.

${ }^{34}$ Artigo publicado na Revista Portuguesa de Arqueologia, volume 4, número 2, 2001, p. 293-349. 


\section{d) A explicação}

Tive ocasião de dirigir a tese de mestrado de Fernanda Cristina Repas ${ }^{35}$. O trabalho ainda está inédito; contudo, não posso deixar de sublinhar que, se em relação a Arentius e Arentia, Fernanda Repas não ousa ir além do que habitualmente se escreve a este propósito, já o facto de à divindade Banda (designação simplificada do teónimo que aparece, como se sabe, grafado de diferentes maneiras), se juntarem epítetos ora masculinos ora femininos a leva a considerar, "como hipótese, que a divindade assume quer o género masculino, quer o feminino, tal como recentemente se demonstrou em relação a algumas divindades clássicas" (p. 98) - e apoia-se na obra de Sabino Perea.

Vou mais longe.

Primeiro, assumo que a questão do sexo em relação a Banda não constitui problema: a divindade é masculina ou é feminina, consoante os dedicantes a querem 'ver'. Não que se pense que um dedicante masculino veja na divindade o lado feminino ou vice-versa; em meu entender, não é uma questão de sexo, é uma questão de ideologia e - porque não? - de percepção do momento. Não há uma regra estipulada, não há uma ocasião para o deus ser masculino e outra para ser feminino: ele é uma e outra coisa! Não há, pois, que nos admirarmos se ele se apresenta como a Tyché helenística e em vestes de Genius Loci! Assim como a forma claramente feminina - do ponto de vista gramatical - do teónimo Tutela se coaduna com o facto de vir precedida do identificativo deus, no masculino: Tutela é masculina e feminina ao mesmo tempo. Ao dedicante compete, neste ou naquele momento, invocá-la sob uma forma ou outra, consoante a sua sensibilidade.

Assim também - e aqui a conclusão afigura-se-me lógica - não há, em minha opinião, uma deusa Arentia e um deus Arentius. Não há um par divino. Há, sim, um deus que assume características femininas e características masculinas e, por isso, tem um nome feminino e outro masculino - mas é o mesmo! Do mesmo modo que as dedicatórias Libero et Liberae: não estamos perante duas

\footnotetext{
35 Intitulada Religião na Beira Interior ao Tempo dos Romanos (Subsídios para o Seu Estudo), foi defendida e classificada com "Muito Bom" em Maio de 2001, na Faculdade de Letras de Coimbra.
} 
divindades, como Sabino Perea já acentuou, mas a mesma sob duas designações sexualmente diferenciadas, porque assim a divindade era entendida!

E tudo isto vem, por conseguinte, na linha directa das observações feitas por aquele investigador em relação ao uso da expressão sive deus sive dea ou das dedicatórias diis deabusque de uma determinada cidade.

\section{e) Fontanus/Fontana - um caso de ambiguidade}

Amiúde tenho referido que, nos monumentos epigráficos romanos - tal como mandam as mais avançadas e acutilantes técnicas do marketing dos nossos dias - a ambiguidade era... cultivada.

Escrevi-o, por exemplo, em relação às siglas D. D. postas em relevo no final de monumentos funerários e outros, sem que isso implique a interpretação $\mathrm{D}$ (ecreto) D(ecurionum) de preferência ao banal D(ono) D(edit) sem conotações políticas - mas era importante que houvesse a dúvida e a leitura, mesmo no dia-a-dia, pudesse resultar ambígua ${ }^{36}$.

Comentei-o, no Colóquio Borghesi, em Génova (Setembro de 2001) ${ }^{37}$, acerca da palavra Victor, patente, por exemplo, nas paredes do grande lupanar de Pompeios, que não será necessariamente um antropónimo mas que também pode ser - e será - o adjectivo victor, 'o que venceu' - tal como os Victores pintados, de acordo com a tradição, nos claustros da Universidade de Salamanca...

Também na questão da designação das divindades essa ambiguidade se observa, mormente se se recorrer ao uso das siglas.

Já tive igualmente ensejo de observar que, frequentemente, a identificação de teónimos por meio de siglas mais não significa que estamos perante o local habitual de culto da divindade e que, por isso, ela é suficientemente conhecida e facilmente identificável. 38

Há, porém, neste aspecto, um caso deveras significativo.

\footnotetext{
36 Vide "Decreto decurionum - algumas notas sobre o mecanismo decisório municipal na Hispânia romana", Ciudad y Comunidad Cívica en Hispania (siglos II y III d. C.), Madrid, 1993, 59-64.

37 "Euge, victores! Ou le culte de l'ambigüité", Serta Antiqua et Mediaevalia, VI, Roma, 2003, p. $167-173$.

38 Cf. Veleia 2-3 1985-1986 307-308.
} 
Numa árula de calcário achada junto da nascente de águas termais de Monte Real, localidade do concelho de Leiria, na faixa atlântica portuguesa entre os rios Tejo e o Mondego, o dedicante, Frontonius Avitus, apenas mandou gravar na linha 1: F. S. Se o S facilmente se desdobra em S(acrum), já o F pode ter interpretações diversas e assim o foram entendendo os vários investigadores que estudaram o monumento, conhecido já desde os tempos de Emílio Hübner ${ }^{39}$. Hübner optou por F(ortunae); os demais, sempre com pontos de interrogação, sugeriram $\mathrm{F}$ (onti), F(ontanae), $\mathrm{F}$ (ontibus)... mas igualmente se poderia ter aventado $\mathrm{F}$ (ontano).

Curiosamente, numa ara de Ervedal, no concelho de Avis (IRCP 437), Threptus, escravo de Caius Appuleius Silo, homenageia uma divindade $o b$ aquas inventas. Trata-se, como é natural, de uma divindade das águas; mas... masculina ou feminina? Aí Threptus hesitou e o lapicida resolveu-lhe habilmente o problema: escreveu FONTAN, sem a vogal final - que cada qual entendesse como quisesse!...

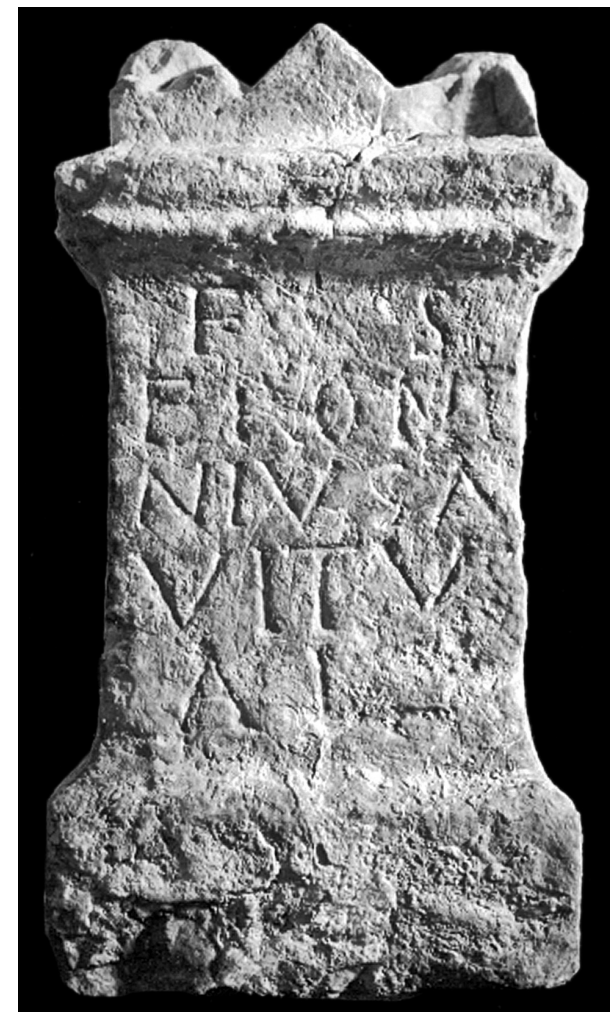

143

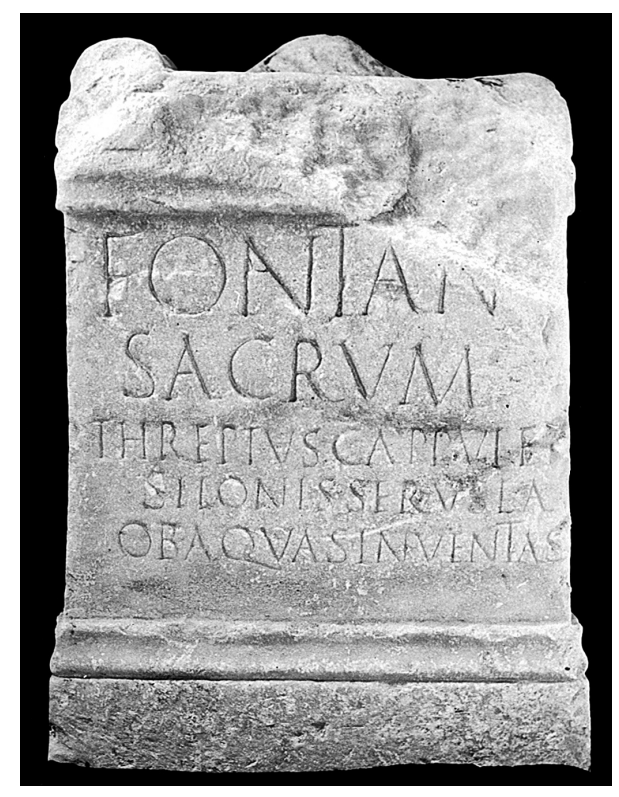

39 CIL II 337 = ILER 454, AE 192512. 
Em Bencatel, concelho de Vila Viçosa, Albia Pacina quis fazer um voto pela saúde de Albius Faustus, provavelmente seu esposo, liberto, como ela, duma gens Albia $^{40}$. Terá recorrido à força de águas salutíferas famosas na região e, por isso, a divindade invocada seria a ninfa protectora do manancial. Ninfa? Novamente o problema se põe: será masculina ou feminina a divindade que faz brotar tais águas das profundas entranhas da terra? E, de novo, o lapicida a resolver a questão: invocam-se Fontanus e Fontana. Invocam-se? Digo mal: invoca-se o deus do manancial na sua forma masculina e na sua forma feminina. Escrevi em 1984 (IRCP, p. 520) que a "ara testemunhava o culto a um par divino"; não é: é uma divindade única invocada nos dois sexos.

Mais hábil ainda - ou cultor da ambiguidade, se se preferir - foi o lapicida da ara de Monte Real: deixou o teónimo... em sigla! Podem, pois, os epigrafistas esgrimir argumentos a favor de um ou de outro, que nunca chegarão a uma conclusão garantida, porque... os Romanos assim o quiseram!

Como se vê, em conclusão, não é bizantinice abordar a questão do sexo dos deuses; bizantinice será querer atribuir-lhes um sexo - que, na verdade, o não possuem. Pelo menos, na mente de quem os invoca e lhes manda gravar na pedra imorredoira votos de reconhecimento eterno.

\subsubsection{Das religiões e das divindades indígenas na Lusitânia}

\section{Um culminar}

O II volume das Religiões da Lusitânia, de José Leite de Vasconcelos, publicado em 1905, constituiu o culminar de todo um processo de curiosidade e de pesquisa sobre a religiosidade dos povos que, na Lusitânia, antecederam os Romanos; a primeira grande síntese, devidamente sistematizada, que se fazia eco dos estudos anteriores e que apontava, desde já, caminhos para uma válida investigação ulterior.

\footnotetext{
40 CIL II $150=$ IRCP 438.
} 
Na verdade, já desde o século XVI que os curiosos por estas coisas do Passado se haviam posto a questão, com os conhecimentos de Latim que já tinham: que estranhos nomes estes que surgem nas inscrições!? De deuses serão, decerto. E que quererão dizer? Conhecia-se, por exemplo, Endovélico. Seria incarnação demoníaca também?

Em meados do século XIX, davam os primeiros passos os estudos linguísticos - como, aliás, davam nessa altura os primeiros passos todas as ciências, porque surgia uma mentalidade muito mais virada para o concreto, para a experimentação. Os estudos linguísticos, a Etnografia - a que não foi alheia, mais uma vez, a experiência africana no contacto com outros modelos civilizacionais. E iniciou-se um pensamento que via na interdisciplinaridade um excelente meio de compreender o Homem e as suas manifestações nos mais diversos domínios de actuação. E a religião, o relacionamento com o Divino, porque visceralmente intrínseco à natureza humana, tinha, por isso mesmo, de despertar o maior interesse.

O intuito de Leite de Vasconcelos - já o escrevi noutro lugar ${ }^{41}$ - não se desgarra da vertente "nacionalista" (digamos assim) que começava a grassar pela Europa, perante uma "globalização" que, já nessa época, se aprestava para vencer, eliminando localismos. Tal como hoje. Embora incipiente, embora com tintas francamente políticas. E, hoje, as tintas são as mesmas, muito mais subtilmente usadas e disfarçadas...

Para já, "Lusitânia”. A identificação do País com uma província que, rezavam os livros, muitos amargos de boca haviam causado ao invasor, que só pela infame traição lograra instalar-se.

Vira, contudo, bem depressa, que «instalar-se» não poderia significar "destruir", "arrasar". Mormente no que às crenças dizia respeito.

Religião, religiões, divindades...

E Leite de Vasconcelos fala em «religiões». Penso que não haverá, no conjunto da sua obra, nenhum passo em que se explique cabalmente o motivo desta escolha. Hoje, a quase um século de distância, compreendemo-la.

41 "No centenário da publicação das Religiões da Lusitânia: nacionalismo em Leite de Vasconcelos", O Arqueólogo Português 11/12 (série IV) 1993-1994, p. 35-42. 
Primeiro, estrategicamente: são muitas, é difícil vencê-las, substituí-las. Depois, quem há aí que ouse saber exactamente como era, entrar no âmago dum sentimento, ainda que ele possa vir expresso em frases lapidares pensadamente gravadas para todo o sempre?

E falar em "religião" implicava, por outro lado, saber da sua teologia, dogmas, preceitos, rituais... Num todo orgânico, organizado, superiormente regulado, inclusive por uma oportuna intervenção divina, algures na noite dos tempos...

Preferiríamos, hoje, "divindades». Contudo, divindade é um ser; divindades serão muitos seres; e a eventual ideia de uma "dispersão desconexa" também não interessaria transmitir, porque dava sensação de fragilidade, a evitar.

\section{Qualificativos}

Então, mas divindades... quê? Lusitano-romanas? Célticas? Paleo-hispânicas? Ibéricas?

A qualificação de "lusitanas" está compreensivelmente implícita na obra de Leite de Vasconcelos.

"Célticas» foi termo que se importou da zona central da Europa, onde campeava a ideia de os Celtas - loiros, altos, espadaúdos... - serem raça ideal que importaria disseminar... Aliás, provindas de um fundo comum, o indo-europeu, que língua havia aí que celta não fosse?...

"Ibérica" era a contraposição. Os morenos. Vindos doutras paragens, que algures haviam atravessado o estreito de Gibraltar. Aliás, os Lusitanos não eram eles "celtiberos", a fusão ideal das duas componentes rácicas?

A designação "lusitano-romanas" veio depois, quando, por influência dos estudos que ousavam (já) salientar o local, iam no sentido de se tentar compreender que uma cultura, por mais forte que fosse, não se impunha sem sofrer influências do substrato em que tentava assentar. Uma simbiose que, observada nas Áfricas, nos Brasis, nas Índias, também haveria que considerar nos tempos longínquos dos Romanos, inteligentemente políticos - como sempre haviam demonstrado ser. 
E "primitivas"? Soava bem. Vinha ao encontro das investigações sobre os "primitivos actuais" que aos Europeus se haviam deparado nos confins da Insulíndia, nos interiores de África e nos sertões americanos. Nada, porém, havia aí do encanto de Rousseau perante o "bom selvagem". "Primitivo" soava, antes, a rude, grosseiro, mal afeiçoado. Detinha uma conotação valorativa que assentava, mesmo inconscientemente (acredito), no pressuposto que "romano" não era "primitivo", era... "melhor"!

"Paleo-hispânicas" aceita-se. É, porém, um termo híbrido, como se calhar o seriam, na mente popular, estas divindades que em si detinham todos os poderes, ora os de uns ora de outros, consoante as circunstâncias do dia e das aflições. Há, porém, em "paleo-hispânico" igual conotação valorativa que nos pode deixar perplexos: "hispânico" é natural da Hispânia; o prefixo "páleos", do Grego, significa antigo; neste caso, "antigo" em relação a que "novo»? Ao que os Romanos trouxeram? Ao que o Cristianismo implantou?

Optei, pois, por indígenas, 'o que nasce aqui', 'autóctone', 'local' - contra o global. "Contra" não em oposição, mas como "distinto". No sentido que, neste dobrar de milénio, mais se acentua com a globalização e que na frase "todos iguais, todos diferentes" assume superior encanto e ousadia a manter.

\section{Que divindades?}

Para além dos muitos teónimos - rebarbativos e, ainda por cima, atestados, a maior parte das vezes, apenas por um obscuro monumento epigráfico -, outro problema se punha.

Os textos eram singelos. Continham o nome do deus, a sumária identificação do dedicante, a fórmula oficial do cumprimento, decalcada dos formulários jurídicos: cumpri, ninguém me obrigou, aqui está a prova... Como se faria, então, para saber que atributos teriam Endovellicus, Trebaronna, Cosus, Ataegina, Reva Langanitaecus e tantos outros?

Aliás, qual o exacto nominativo correspondente, por exemplo, ao dativo Bandi Brialeacui, se temos Bande Velugo Toiraeco ou mesmo Bandue? 
O contexto arqueológico do achado poderia trazer alguma luz. Assim aconteceu com divindades como Bormanicus, que directamente ligado às termas de Vizela, no conventus Bracaraugustanus, pode ilustrar um dos caminhos seguidos pela investigação neste domínio. Aliás, o vocábulo aparentava-se também perfeitamente com radicais indo-europeus ligados à noção de "quente" - o que se compatibilizava com a noção de personificação divina do carácter salutífero das águas.

Atendendo, porém, ao facto, habitual, de tal contexto se desconhecer, foi exactamente pela análise linguística que se enveredou. Arriscados percursos etimológicos, miudamente seguidos e alicerçados em múltiplos exemplos retirados do gaélico, do sânscrito, do galês... Alguns ofereciam evidências: Igaedus, por exemplo, seria a divindade dos Igaeditani e pouco importará saber se foi o povo que deu o nome ao deus, se este determinou aquele.

Outras hipóteses se afiguravam viáveis para discernir atributos:

- O próprio texto epigráfico poderia ser eloquente: a presença de uma expressão como pro salutem indiciaria - não havia dúvida - o carácter salutífero do númen em questão.

- Se, a determinado momento, as gentes identificaram deuses indígenas com deuses do panteão romano é porque os seus atributos o permitiam. E, assim, comummente se aceitou que Ataegina era o equivalente indígena de Prosérpina.

- Finalmente, se a um determinado culto, perpetuado em tempo romano, os Cristãos fizeram seguir um outro, retirado do seu flos sanctorum, seria legítimo garantir que identidades havia. E, nesse aspecto, o caso de Endovélico é, necessariamente, o mais eloquente, pois que, no local do antigo santuário, se ergueu capela a S. Miguel - e o carácter "infernal", de deus que zela pelo Além, que luta contra as forças do Mal, ficou plenamente justificado.

Esses, os caminhos seguidos. Essas, as análises que - isoladas ou em conjunto - se fizeram em relação a Trebaruna, a Reva (seguramente um deus dos 
rios), a Banda (independentemente de ser esse, ou não, o nominativo mais ajustado)...

Daí que José María Blázquez Martínez, na sua tese de doutoramento, Religiones Primitivas de Hispania (Roma, 1962), tenha seguido o esquema men149 tal proposto por Leite de Vasconcelos e haja agrupado as divindades segundo os seus atributos fundamentais: deuses guerreiros, deuses aquáticos, deuses tutelares...

No fundo, andava no ar a ideia veiculada fundamentalmente por Georges Dumézil de que, tal como as sociedades eram susceptíveis de se dividir em sacerdotes, guerreiros e produtores, haveria uma clara e indesmentível tripartição divina correspondente a cada um desses "estratos" sociais. A teoria foi largamente defendida, o esquema procurou agrupar os deuses e parecia que tínhamos chegado a consensos.

Mas talvez tenha sido precisamente Banda que veio repor a questão: será que, no quotidiano, essa nitidez se vivia? A ninfa duma nascente só era invocada para fertilizar os campos, para sarar doenças ou seria o númen protector de toda uma região onde a sua influência se poderia fazer sentir?

A questão pôs-se sobretudo quando se tiveram de analisar os epítetos com que os vários deuses se faziam acompanhar e que mudavam de região para região. Epítetos “tópicos” se disse de imediato. E nisto acordámos António Tovar, Lourdes Albertos, Jürgen Untermann, eu próprio. "Tópicos”, porque relacionáveis com um "topos”, um lugar - físico ou habitado. Ou seja, colhido da geografia física ou da geografia humana, do povo que aí habitava.

Aliás, seguindo essa linha de pensamento, depressa os indígenas haviam adaptado a seu gosto os deuses tutelares que a mitologia romana lhes oferecia: os Lares, as Ninfas, as Tutelas, os Numina, os... Deuses: Lares Cairienses, Nymphae Lupianae, Dii Deaeque Coniumbrigensium...

Apesar de algumas vozes em contrário, o carácter adjectival dos epítetos divinos parece cabalmente demonstrado e na generalidade aceite, mormente porque se atentou no sufixo -aecus que, sob essa forma "clássica" (digamos assim) ou equivalente, habitualmente os caracterizava. Daí que, hoje, não obs- 
tante o carácter tópico de certas divindades, se prefira atribuir-lhes a função genérica de uma 'tutela' - sobre um povo, uma região, um rio, uma nascente...

Referi António Tovar e María de Lourdes Albertos.

Houvera as largas congeminações de sábios linguistas como o alemão Alfred Holder, para quem essas roupagens teonímicas directamente derivavam do antigo celta. Houvera, entre nós, Francisco Adolfo Coelho, que se declara discípulo do celtista Zeuss e que, em intervenções e em publicações várias (nem sempre do agrado de Leite de Vasconcelos), procura demonstrar a celticidade de deuses peninsulares anteriores à dominação romana (no Congresso Internacional de Antropologia e de Arqueologia Pré-históricas), dissecar os nomes de "deuses lusitânicos" ${ }^{2}$ e analisar os vestígios das antigas línguas da Península Ibérica, estudando os "nomes em aico" ${ }^{4} \ldots$

Nessa mesma ordem de ideias, António Tovar cedo enveredou pelo caminho da linguística pré-romana. As línguas faladas na Península anteriormente à vinda dos Romanos eram o que particularmente lhe interessava. Os teónimos, portanto, apenas um dos veículos de análise. Atitude científica bem compreensível, de resto: sendo a religião, em todos os tempos, um dos elementos mais conservadores da Humanidade, verosímil se tornava que a teonímia - ainda que latinizada, como chegara até nós nas inscrições - haveria de ter seguido de perto os sons primordiais. Uma fina análise etimológica era, pois, susceptível de trazer imensa luz. Tanto Palomar Lapesa como María de Lourdes Albertos, discípulos fiéis de A. Tovar, seguiram-lhe as pisadas, mas alargaram a sua pesquisa, ou melhor, encaminharam-se de preferência para a onomástica e para a teonímia.

As conclusões dos seus estudos foram facilmente aceites, porque se baseavam em dados comparativos lógicos.

\footnotetext{
42 In Revista Lusitana I 1887-1889 351-378.

43 In Revista de Guimarães III 1886 169-188.
} 


\section{$O$ "retorno à pedra"}

Desde cedo, porém, feita esta primeira panorâmica na década de 60, se deduziu que uma análise de teor linguístico carecia de uma base fundamental: leituras garantidas. Ou seja, surgiam, por vezes, congeminações a partir de informações nem sempre verificadas no monumento.

Urgia um "retorno à pedra", agora que as técnicas fotográficas haviam avançado, os conhecimentos se alargavam mediante maior circulação da informação e outras questões se colocavam.

Isso se fez na década de 70 e a publicação de Divindades Indigenas sob o Dominio Romano em Portugal (Lisboa, 1975), apesar dos cinco anos de atraso sobre a sua defesa como dissertação de licenciatura na Faculdade de Letras de Lisboa, viria chamar a atenção para essa necessidade.

Curiosamente, sai nesse mesmo ano uma compilação, da autoria de José María Blázquez, sob a forma de dicionário ${ }^{44}$ na visível preocupação de 'arrumar' tantos teónimos que o incremento dos estudos epigráficos estava dando a conhecer.

E uma reflexão se impôs: havia deduções erradas porque partiam de leituras duvidosas ou mesmo insustentáveis. E uma interrogação: está mesmo a aumentar, aumentará indefinidamente o número de deuses, num politeísmo alastrador?

E veio de novo a terreiro a questão dos epítetos e a possibilidade de algumas divindades se assumirem como grandes divindades tutelares - Arentius, Banda, Cosus, Reva... - passíveis de, por vezes, serem nomeadas apenas pelos epítetos, sem que, por isso, se deva acrescentar um nome à lista elaborada.

Esse retorno à pedra e as reflexões que possibilitou tornaram-se, pois, imprescindíveis a partir da década de 80, com resultados, por vezes, inesperados.

E se um criticismo sistemático nem sempre poderá aceitar-se - estamos a recordar a nova proposta de leitura apresentada por Amílcar Guerra e Carlos Búa para a árula a Mandiceus do Museu de S. Miguel de Odrinhas, no decorrer dos trabalhos do II Colóquio Internacional de Epigrafia «Divindades Indígenas e Interpretatio Romana" (Sintra, Março de 1995) - também não é menos verdade

\footnotetext{
${ }^{4}$ Diccionario de las Religiones Prerromanas de Hispania, Ediciones Istmo, Madrid, 1975.
} 
que é esse espírito crítico que pode trazer luz a dúvidas há muito levantadas. E lembraria, a propósito, a perspicácia desses mesmos dois autores ao verem, na ara de Lisboa tida, durante muitos anos, como dedicada a Júpiter Asseco a homenagem a uma outra divindade indígena: Kassaecus. Essa leitura, dada a conhecer no VII Colóquio sobre Lenguas y Culturas Paleohispánicas (Saragoça, Março de 1997), veio anular todas as elucubrações linguísticas até aí aventadas e propôs outras novas, de auspicioso futuro ${ }^{45}$.

E tem sido, não há dúvida, nestes últimos colóquios, que inovadoras reflexões vão surgindo. Nomeadamente em Vitória e em Salamanca, aqui em torno duma equipa que Francisco Villar começou a interessar e que vem dando fruto através, por exemplo, das pesquisas de índole linguística dele próprio e de Blanca Prósper, aplicadas à teonímia (Ocrimira, Nabia, Cosus, Trebaruna...).

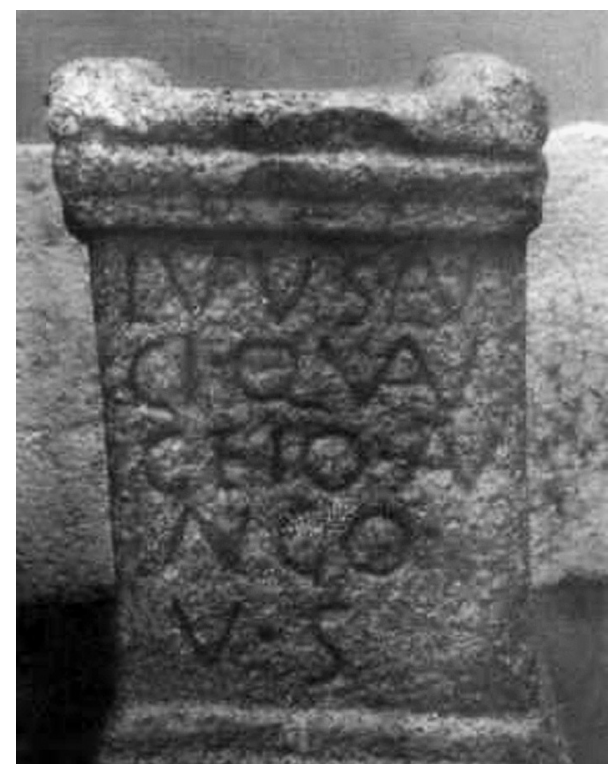

\section{Um exemplo: Quangeius}

É vulgar, hoje, em Ciências Sociais e Humanas, assim como nas Ciências Experimentais, fazerem-se "estudos de caso" tendentes à clarificação das temáticas em análise.

Vejamos, pois, a título de mero exemplo, o percurso que cientificamente pôde levar o estudo duma dessas divindades indígenas: Quangeius.

Identificada em Salavessa, na freguesia de Montalvão, concelho de Nisa, no Nordeste alentejano - zona que, ao tempo dos Romanos, segundo as últimas investigações, poderá quiçá ter estado integrada no conventus Emeritensis - a ara dedicada a esta divindade apresenta recorte grosseiro, comparável a idênticos monumentos dessa região.

\footnotetext{
45 Cf. Pueblos, Lenguas y Escrituras en la Hispania Prerromana, Salamanca, 1999, 331-338.
} 
Deram-na a conhecer, sucessivamente, Francisco Henriques e João Carlos Pires Caninas na edição de 9 de Janeiro de 1981 do jornal Reconquista, de Castelo Branco, e Manuel Leitão no mesmo periódico, na edição do dia 30. E se estes dois apontamentos fizeram a abordagem inicial do monumento, e eu próprio o incluí nas Inscrições Romanas do Conventus Pacensis (Coimbra, 1984, sob o nº 641), seria José Manuel Garcia, na revista História (n⿳⺈ 76, Fevereiro de 1985 , p. 23-32), que lhe viria a dedicar maior atenção, relacionando-o de imediato com outros testemunhos existentes, cuja identificação propôs.

Apesar de ostentar uma série invulgar de nexos e de poder haver alguma hesitação entre C ou G nas duas últimas linhas, o texto parece poder ler-se sem dúvidas de interpretação:

\section{LVPVS $\cdot$ LAN/CI (filius) $\cdot$ QVAN/GEIO · TAN/NGO · / V(otum) $\cdot \mathrm{S}$ (olvit)}

Lupo, filho de Lanco, cumpriu o voto a Quangeio Tango.

A nitidez com que a parte inicial do teónimo se apresentava levou, como disse, a repensar a interpretação feita, até aí, duma outra epígrafe, proveniente de Malpartida de Plasência (ILER 802), que se considerava dedicada a um deus Dovanceio. Claro está que José Manuel Garcia partiu, de imediato, para a revisão daquele texto, propondo:

MEARVS / MEIDVENI / F( ilius) V(otum) S(olvit) D(eo) / QVANCEIO / A(nimo) $\mathrm{L}($ ibens)

Mearo, filho de Meidueno, cumpriu de boa vontade o voto ao Deus Quanceio.

Entretanto, Fernando Patrício Curado identificara, numa das colunas do alpendre da capela da Senhora do Bom Sucesso, em Penamacor, uma outra ara (FE 26), para que se propôs a leitura seguinte:

\section{CATVRO / TVREI F(ilius) DEO / QVANGEIO V(otum) S(olvit)}

Caturão, filho de Tureio, cumpriu o voto ao Deus Quanceio. 
Mas não ficaram por aqui as descobertas, desencadeadas, como se vê, em brevíssimo espaço de tempo. De facto, uma ara de Bemposta, também do concelho de Penamacor, cuja leitura se afigurava difícil devido ao mau estado da superfície epigrafada, foi igualmente revista. E se o nome da dedicante oferece alguma dúvida - CARPA (?) TONGI F(ilia) - as letras VAN legíveis na linha 3 podem adequar-se, sem problema de espaço, a uma reconstituição [Q]VAN[GEI]O (HEp 4 nº 1044).

Mais clara é, porém, outra ara, procedente da freguesia de Sortelha (concelho de Sabugal), dada também a conhecer por Fernando Patrício Curado, em 1987 (FE 100.1):

\section{TANGINVS / TVRANI · F(ilius) / QVANGEIV / V(otum $) \cdot \mathrm{S}$ (olvit)}

Tangino, filho de Turano, cumpriu o voto a Quangeio.

E, nas proximidades, deparou o mesmo investigador com a parte inferior duma outra ara (FE 100.2), onde reconstituiu [QV]ANGEI[O] e a fórmula final $\mathrm{A}($ nimo) L(ibens) V(otum) S( olvit).

De leitura e interpretação mais duvidosas, mas igualmente passíveis de atribuir-se ao culto a esta divindade, são dois outros monumentos de Nisa. Um, identificado por F. Patrício Curado (FE 103), teria QV[AN]GEO a anteceder a fórmula final. No outro, Rogério Carvalho (FE 106) sugeriu a leitura, ainda que hipotética dado o mau estado da pedra, QVANCEIO TANGO.

Em nota ao texto sobre a citada ara de Nisa (FE 103), Patrício Curado, atendendo a todos estes exemplos, confirma que, numa ara de Capinha (concelho do Fundão), se deverá ler [Q]VANGE[IO]. A dedicante é Camira Bouti f(ilia) e a fórmula dedicatória V(otum) L(ibens) S( olvit) (AE 1977 356).

Num outro horizonte cultural, já fora, inclusive, da Lusitânia - mais concretamente em Verín, na Galiza - é igualmente provável (acrescenta F. Patrício Curado nessa mesma nota) que a leitura I $\cdot \mathrm{O} \cdot \mathrm{M} \cdot \mathrm{GEIO}$, de Alain Tranoy, deva dar lugar a QVAN/GEIO, num monumento dedicado por G. Iulius Severinus (AE 1987 562j). 
Finalmente, identificava José Rafael Correia da Silva "Agrícola", em Junho de 1991, num antiquário de Borba (distrito de Évora), outra eṕ́grafe, verosimilmente um pedestal, que Rafael Alfenim estudou (FE $174=$ AE 1991 946). A leitura não oferece quaisquer dúvidas:

C(aius) · LICINIVS · VEGETVS / QVANGEIO · TVRICAECO / V(otum) (hedera) $\mathrm{L}$ (ibens) (hedera) $\mathrm{A}$ (nimo) (hedera) S(olvit) (hedera)

Gaio Licínio Vegeto cumpriu de boa vontade o voto a Quangeio Turiceco.

O caso é, como se vê, deveras paradigmático. O achamento de um monumento com boa legibilidade acarretou, de imediato, a correcção de leitura doutras três epígrafes e veio possibilitar a interpretação de mais seis - interpretação confirmada plenamente pela última dedicatória identificada. Ao todo, onze monumentos num brevíssimo lapso de tempo.

Todos os dedicantes (com excepção do da Galiza e do de Borba) se identificam à maneira indígena e ostentam onomástica tipicamente lusitana (se assim se pode falar). Mas as duas excepções não deixam de ser deveras significativas, uma vez que - identificando, com muita verosimilhança, indígenas romanizados, porquanto usam os tria nomina-demonstram quanto este culto, além de assaz expandido, acabou por perdurar, assumindo-se agora Quangeius, dada a ocorrência de epítetos, como uma divindade mais a juntar ao rol das divindades mais veneradas na Península Ibérica.

Mas que significará Quangeius? Será possível obter para o teónimo uma etimologia?

Consultei, para o efeito, Francisco Villar, que me respondeu não conhecer, de momento, nenhuma proposta concreta. Adiantou, no entanto:

"Desde el punto de vista formal, podría ser impecablemente explicado como *kuanikio- que es un adjectivo derivado del nombre indoeuropeo del "perro". En alguna lengua indoeuropea existe una formación derivacional idéntica. Pero la etimología requiere también una coincidencia en el aspecto semántico. En el caso de Reve, especialmente favorable, yo ensayé el método de entrever la realidad semántico-referencia de la palabra Reve utilizando los epitetos. Y en aquel caso creo que funcionó. 
En el caso de Quangeio, las cosas son menos favorables porque la mayoría de las veces aparece sin epíteto; y las dos ocasiones en que hay epíteto son simples topónimos (Turicaicum de um Turicum); e Tanngo recuerda el Tongobriga de Lusitania.

Al fallar la corroboración semántica de la etimología, tan sólo queda recurso a otro tipo de consideraciones que busque congruencias de interés, como podría ser culto al perro o a una divinidad protectora de los perros. Esto último sería lo más en consonancia con la forma que no es "el perro" sino "el [dios protector] de los perros". Así como si en latín dijéramos "[deo] canico".

Otra possibilidad semántica es que no se refiera al perro animal, sino a la constelación del "perro" (canis, canicula en latín, kuon en griego)."

Ao referir Turicum, Francisco Villar remete para os seus Estudios de Celtiberico y de Toponimia Prerromana (Salamanca, 1995), onde perfilha a opinião de que estaremos, na verdade, perante um topónimo, de raiz celtibérica, relacionável com um antropónimo atestado, Turos. Rafael Alfenim avançou a hipótese de Turiceco poder ser adjectivo formado a partir de um etnónimo, os Turicecos, que nada impede de serem considerados os habitantes de Turicum.

No que se refere a Tanngus, a relacionação com Tongobriga não deixa, também, de ser aliciante; contudo, a aproximação com um possível Tangus donde teria derivado o diminutivo Tanginus - não se me afigura despicienda. Aliás, não há que terçar armas, em meu entender, por uma posição rígida a tal propósito, atendendo a que um território bastas vezes se identifica com um povo, com a família que o habita, e essa família ou esse povo se encontram intimamente ligados ao território em que se movimentam.

E se - como já Rafael Alfenim teve ensejo de referir - Turicaecus lembra o teónimo Turiacus registado na Galécia, Tanngus não deixa de remeter para o epíteto de uma outra divindade tutelar: Arantius Tanginiciaecus.

\section{As variantes gráficas}

O exemplo aduzido servirá igualmente para se fazer o ponto da situação acerca de um outro tema que vem seduzindo os linguistas e sobre o qual se têm 
feito inúmeras considerações. Na verdade, é anómala aqui a presença de dois NN, dificilmente concebível em Latim. Como entendê-la?

Creio que por duas possíveis razões, ambas de índole cultural ou, se se preferir, literária.

Pode o lapicida ter querido passar a escrito, com a maior fidelidade possível, o som que lhe era transmitido. Nem toda a gente saberia pronunciar da mesma forma os nomes dos deuses e, por isso, nem sempre a grafia do teónimo é uniforme. Cite-se, de novo, no dativo, um dos exemplos mais conhecidos e sintomáticos: Endovellico, Enobolico, Endovollico...

Poder-se-á, a partir daí, determinar áreas linguísticas, um pouco ao jeito do que Untermann, no seu Atlas Antroponimico, procurou discernir apontando, por exemplo, uma área do -t- e outra do - d- (digamos desta forma, para simplificar o raciocínio)? É provável que sim, que a análise de um conjunto significativo de casos, devidamente localizados, possa sugerir tendências, conclusões. Um dado, porém, nos parece adquirido e irrefutável: essas variantes são reflexo de deficiente cultura literária. Sabe-se falar, pode não se saber escrever correctamente.

Outra justificação - que, no fundo, vai no mesmo sentido ainda que por via diferente - é a dificuldade de interpretação da minuta, por o lapicida desconhecer por completo o significado do que lhe é solicitado para escrever. E, neste caso, não vale a pena linguistas, filólogos, epigrafistas esforçarem-se a encontrar respostas para o que... outra resposta não tem.

Que se me permita a demonstração mediante dois exemplos recentes e reais.

Arciania foi antropónimo interpretado a partir da leitura de epígrafe romana (CIL II 322) veiculada por um manuscrito do século XVII. Alfred Holder não hesitou em considerá-lo etimologicamente pré-romano e de muito provável origem céltica. E, decerto, análises várias ainda se adregariam daí deduzir, comparações, confrontos, se, por mero acaso, o epitáfio não tivesse sido reencontrado. José Cardim Ribeiro e eu próprio tivemos, pois, oportunidade de desfazer o erro e de mostrar que estávamos perante o genitivo do cognomen latino Marcianus, seguido muito simplesmente do A inicial da palavra AN(norum) ${ }^{46}$.

\footnotetext{
${ }^{46}$ Cf. Humanitas L 1998 189-197.
} 
O outro caso nada tem a ver com Romanos. Chegou-me às mãos, vinda de Espanha, uma carta endereçada a alguém morador em ALGIA F 420, escrito assim, em capitais. Aposto que ninguém, por mais tratos que dê à imaginação, consegue decifrar o significado destes dizeres, se não estiver dentro do contexto e não tiver motivação epigráfica. Na verdade, o código postal que vem abaixo pertence a uma povoação que se chama ALDEIA DE JUZO. Que aconteceu, então? O correspondente espanhol desconhecia por completo o nome da terra e tentou copiar o melhor que pôde o que vira manuscrito no remetente da carta que oportunamente lhe fora enviada. Desta sorte, DE "virou» G; o outro DE ficou F e de JUZO se fez 420! Isto aconteceu em Janeiro do ano 2000, entre pessoas letradas. Simplesmente, uma está completamente fora do contexto e não conseguiu entender nada do que a outra lhe escrevera.

No caso dos teónimos indígenas, mesmo que o lapicida soubesse ler, quem nos garante que ele compreenderia bem palavras que não lhe eram minimamente familiares?

Sirvam os dois exemplos - reais, repito - para acautelar elucubrações sem fundamento.

\section{No dealbar do novo milénio}

Finalizemos esta panorâmica focando um outro aspecto muito importante e de não somenos actualidade, que nunca será de mais salientar: a tolerância mútua - como significante profundo de tudo o que temos estado a referir.

Está bem que os indígenas se terão deixado inebriar pelo modo como os Romanos tratavam os seus deuses e cumpriam suas promessas. Não temos não podíamos ter - informação acerca do modo como, dantes, eles viviam a relação com o Além. Um gesto, um lançar de flores à corrente, o queimar de essências ou a imolação de cria recém-nascida - seriam provas de devoção, no sentido íntimo da palavra: "entrega", sinal de dependência, preito de vassalagem (como o será em tempos medievais). E nada disso nem arqueólogos nem epigrafistas podem encontrar - que rasto de tal não fica. 
De outros povos os Romanos haviam trazido esta forma de perpetuar pela escrita, na pedra, o acto religioso, o cumprimento.

Era aliciante imitá-los.

E cedo os indígenas terão aprendido.

E mesmo no penedo que sempre lhes parecera, pela sua solidez, pela sua localização em sítio ermo e de mistério, local adequado para, sem pressas nem outros ruídos, se unirem às divindades telúricas, mesmo nesses rochedos as inscrições balbuciantes apareceram.

Ensinaram os Romanos que também na cidade poderia haver templos. Os deuses, decerto, também gostariam de ter casa própria e aí se lhes depositarem oferendas. E surgem, por isso, as réplicas de altares, as aras, as árulas, inclusive para, mais tarde, em ambientes um tudo-nada mais requintados, devidamente se colocarem em apropriado nicho, no larário das devoções familiares, de mistura com os antepassados...

E aceitou-se o latim. Mal amanhado a maior parte das vezes, que se não compreendia bem ou os nomes dos deuses, como vimos, soavam tão a destempo para o lapicida (mesmo que letrado) que uma vez escreveria duma forma, outra doutra, que era preciso agradar ao cliente e ser o mais fiel possível ao som habitualmente pronunciado, na difícil arte de passar a escrito o que se ouve ou que mal se compreende, porque não se está dentro do contexto exacto. E quem o estaria, mesmo então?...

Não ousamos, pois, falar de religião.

Nem de religiões sequer, que disso pouco sabemos.

Falemos de deuses.

À nossa medida.

Porque, afinal, foi o Homem - ontem como hoje - que lhes emprestou corpo, forma, nome e atributos. Para, servindo-os, deles a todo o momento almejar servir-se. Vestindo-os de uma imortalidade e de um poder que, sabendo-os inatingíveis, qual Ícaro, sempre aspirou conseguir. 


\title{
4.3 Monumentos bonoríficos
}

\subsubsection{Em sintese}

160

À identificação do homenageado acrescenta-se a menção dos cargos que ocupou, elogia-se porventura a sua actuação e refere-se o motivo da homenagem. Os dedicantes identificam-se também, e explicitam por vezes como obtiveram fundos para a homenagem (por exemplo: aere collato, por subscrição pública).

No final, pode vir expressa a intervenção directa das autoridades municipais ( $\mathrm{DD}=$ decreto decurionum, por decreto dos decuriões) ou a informação de que o homenageado, contente com a honra, que aceitou, pagou as despesas a ela inerentes: honore contentus impensam remisit (H. C. I. R).

\subsubsection{Um exemplo}

Sirva-nos de exemplo um pedestal, de mármore de Trigaches, que se encontra no Museu da Rainha Dona Leonor, em Beja. Mede 84 x 56,5 x 50; já o estudei com algum pormenor (IRCP 241); a sua inscrição reza o seguinte:

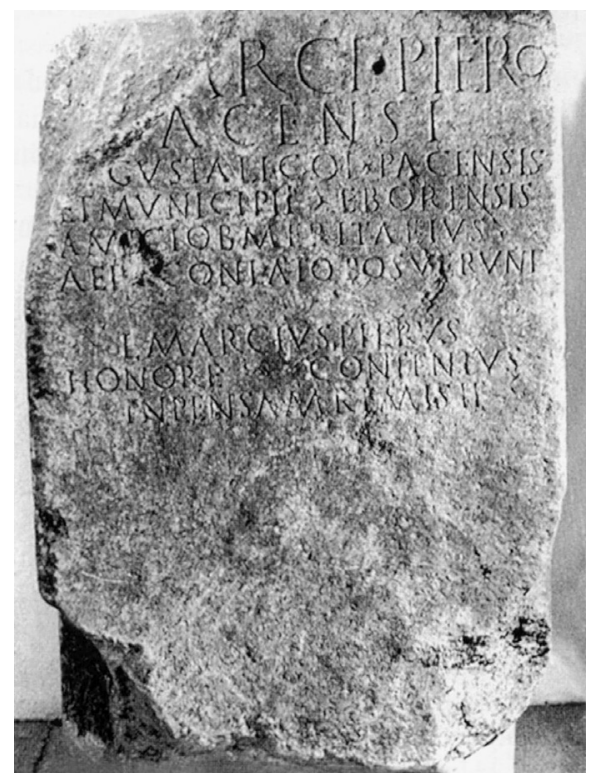

\author{
L $\cdot$ MARCIO PIERO \\ PACENSI \\ AVGVSTALI $\cdot$ COL $\cdot$ PACENSIS \\ ET MVNICIPII · EBORENSIS \\ AMICI OB MERITA EIVS • \\ AERE CONLATO POSVERVNT \\ L MARCIVS PIERVS \\ HONORE · CONTENTVS \\ INPENSAM REMISIT
}


A Lúcio Márcio Píro, natural de Pax Iulia, augustal da colónia pacense e do município eborense - os amigos, devido aos seus méritos, por subscrição pública erigiram.

Lúcio Márcio Píro, satisfeito com a honra, pagou a despesa.

No que à linguística propriamente dita diz respeito, assinalaríamos conlato (em vez do mais correcto collato, onde a assimilação já vingou) e o lapso inpensam (com $\mathrm{n}$ antes do p), a denotar distracção ou mesmo ignorância. Atentar-se-ia também - para melhor compreensão do que a seguir se explicitará - no valor etimológico de remisit, "restituiu".

Não há dúvida, porém, que o importante será partirmos para o significado último do bem paginado monumento, para o seu valor como documento político-social. "Político-social", disse bem, porque se trata da homenagem pública a um benemérito (ob merita eius).

$\mathrm{Na}$ verdade, se todos os textos epigráficos são, como escreveu Giancarlo Susini, "para informação pública e permanente", os honoríficos, como este, são-no de modo particular. Tivesse ou não estátua, era suficientemente impressionante para que não fosse visto por quantos ali passavam, no fórum evidentemente. E não seria raro a criança tentar soletrar a mensagem e perguntar aos pais que a traziam pela mão quem era esse tal L. Márcio Píero, porque lhe tinham escrito aquilo. E a explicação serviria, como é óbvio, de acrescida propaganda. O nome seria fixado, que houve o cuidado de o gravar em módulo maior, para que bem se visse. Os outros Marcii - que decerto os haveria ainda na cidade, a governar, com significativo estatuto social, político e económico viam, assim, a sua influência aumentar. E maiores possibilidades de consolidarem posições.

Mas quem era Píero? Um augustal. Membro do colégio de seis membros eleitos, encarregados de zelar pela manutenção do culto imperial. Natural da cidade, não foi apenas aí que exerceu tais funções: também o vizinho município de Évora o escolheu. Não sabemos, no actual momento da investigação, se este cargo era exercido simultaneamente nas duas cidades; para o caso, porém, 
a discussão não interessa, pois, de uma forma ou doutra, o certo é que Píero era influente numa e noutra e fidelíssimo ao poder central. Píero ou os Marcii? A questão é sobremaneira pertinente se atentarmos no seu estatuto social: estamos

perante um liberto, porque o colégio dos augustais era constituído por libertos. Por consequência, a homenagem a Píero representa, afinal, a homenagem aos seus patronos, também eles beneméritos - com toda a carga sociopolítica que (como sabemos) a benemerência detém...

E de quem partiu a iniciativa do público reconhecimento? Da cidade, oficialmente, por decreto dos decuriões? Não! Dos... "amigos"!

Dos "amigos"?

É isso que reza na pedra. Mas, bem vistas as coisas, não são os "amigos do peito", dos que cultivam a amizade pura. Aqui, "amizade" implica um conceito muito mais lato: são os correlegionários, os apoiantes, os clientes, a "base social de apoio", como diríamos na linguagem do nosso quotidiano político. Tem, de facto, a palavra "amigos" inúmeras conotações e, num monumento epigráfico, detém um significado que vai para além da mera relação de afecto, sentimental: é, concomitantemente, uma ligação social, económica, cultural... Numa palavra: clientelismo! ${ }^{47}$.

Ora, então, os "amigos" cotizaram-se, fizeram uma subscrição, os seus nomes vieram na lista e, à frente, a importância com que cada um tinha "entrado". "Publicou-se" a lista e - pasme-se! -, homenagem feita, o homenageado declara-se infinitamente reconhecido e solenemente proclama que não, senhores, sou eu quem paga, devolvo-lhes o dinheiro a cada um!...

Dupla benemerência, portanto: a que motivara o movimento e a que o movimento motivara!...

E, aqui, cada um de nós, a dois mil anos de distância, dá consigo a pensar em homenagens outras, também elas eminentemente "voluntárias", "espontâ-

\footnotetext{
${ }^{47}$ Há diversos textos em que este tema já foi abordado, no que à época romana diz respeito. Poderá ver-se: REALI (Mauro), Il Contributo dell'Epigrafia Latina allo Studio dell'Amicitia: Il Caso della Cisalpina, Firenze, 1998. Na Península Ibérica, J. M. Serrano Delgado tem dedicado ao assunto alguma atenção; dele poderemos citar: "Documentos adicionales relativos a la amicitia", Habis, 20, 1989 , p. $175-183$.
} 
neas", "dos amigos"... E concluímos, à boa maneira de La Palisse, que... "nada há de novo sob o Sol”.

\title{
4.4 Inscrições monumentais
}

\subsubsection{Em sintese}

Referem circunstâncias da construção do monumento (templo, ponte, aqueduto, circo...), data, personalidades a ela directamente ligadas, divindade a que porventura foi consagrado.

São célebres as duas inscrições da ponte de Chaves, sobre o Tâmega: uma (CIL II 2478) informa que essa ponte de pedra foi concluída ao tempo de Trajano; a outra (CIL II 2477 = 5616) lembra uma obra empreendida pela VII legião e subsidiada pelos povos vizinhos. Também na ponte de Alcântara, em Espanha, sobre o rio Tejo, existe cópia de uma epígrafe (CIL II 760), onde se enumeram as populações que contribuíram para a sua construção.

\subsubsection{Um exemplo}

Foi encontrada em Lisboa, no ano de 1772, "nas casas do correio-mor do Reino, Conde de Penafiel", uma inscrição que tem sido largamente referida, dado o seu teor:

\author{
THERMAE CASSIORVM \\ RENOVATAE A SOLO IVXTA IVSSIONEM \\ NVMERI $\cdot$ ALBANI $\cdot \mathrm{V} \cdot \mathrm{C} \cdot \mathrm{P} \cdot \mathrm{P} \cdot \mathrm{L}$ \\ CVRANTE AVR · FIRMO \\ NEPOTIANO ET FACVNDO COSS
}

O texto não oferecia qualquer dúvida de leitura nem de interpretação, pelo que passou a ser transcrita habitualmente sem objecções. Assim, desdobradas as siglas, a epígrafe reza o seguinte: 
"Termas dos Cássios. Reconstruídas desde os alicerces, a mandado de Numério Albano, varão muito ilustre (vir clarissimus), governador da província da Lusitânia (praeses provinciae Lusitaniae), sendo encarregado Aurélio Firmo, no ano em que foram cônsules Nepociano e Facundo".

Tudo muito claro, portanto:

1 - Estava-se perante um edifício termal, cuja construção original se ficara a dever à família dos Cássios, de que a epigrafia olisiponense guardava outros testemunhos.

2 - Por outro lado, informava-se que o estado de degradação do edifício era tal que só uma reconstrução total seria viável: renovatae a solo.

3 - O próprio governador da Lusitânia se empenhara a fundo na questão, certamente a pedido dos Olisiponenses, que há muito se veriam privados de um edifício público que muito lhes agradaria; daí que tivesse emitido ordem (iussio) nesse sentido.

4 - Trabalho de certa envergadura necessitaria de um responsável, perito; e também isso ficou acautelado, sendo Aurélio Firmo nomeado para o efeito.

5 - Orgulho haveria igualmente na obra consumada e conviria registar-se para a eternidade o ano em que tal iniciativa se dera por concluída: os cônsules referidos são Flávio Popílio Nepociano e Facundo, do ano 336 da nossa era.

\section{O testemunbo de Hübner}

Emílio Hübner teve conhecimento desta epígrafe e informou tratar-se de uma "tegula inscripta litteris minio pictis".

Ao reflectir melhor sobre a informação - um texto monumental pintado numa telha?... - levantei a hipótese de se ter encontrado não a inscrição original, mas a sua minuta, uma vez que, na verdade, aí se identificava o monumento, se referia a obra feita, quem a ordenara, quem dela se encarregara e quando: 
"O lapicida, ou melhor, o ordinator, serviu-se de um pedaço de cerâmica lisa para aí pintar o texto que o seu operário deveria paginar e gravar depois, num grande lintel, a figurar na fachada das termas, com toda a pompa e circunstância...".

E acrescentei:

"Hübner e as suas fontes não repararam no insólito; ninguém tomou consciência da forma como as letras estavam gravadas - certamente bem legíveis e em capitais - e o texto foi amiúde comentado, sem que se tenha apercebido da sua extrema importância do ponto de vista da história da Epigrafia" ${ }^{48}$.

Chegado, porém, a este ponto, a dúvida começou a instalar-se no meu espírito: seria mesmo... uma "telha»? E porque é que, na tradução do primeiro relatório feito por Hübner à Academia ${ }^{49}$, Soromenho escrevera: "uma inscripção achada no anno de 1772 em um dos compartimentos, escripta em lettras vermelhas sobre rebocon?...

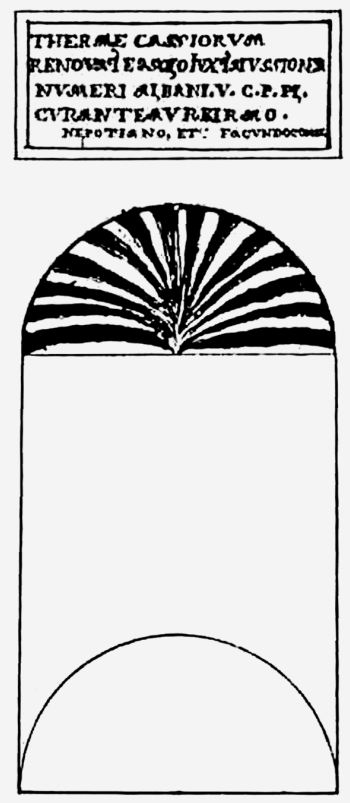

Comecei, pois, a pesquisar as fontes de que Hübner se servira e que vinham indicadas na ficha da inscrição ${ }^{50}$. Nenhuma punha em dúvida o texto. Antes: enquadravam-no claramente num compartimento de paredes pintadas, onde figu-

48 ENCARNAÇÃO (José d'), "Des nouveaux textes, les directions nouvelles de la recherche épigraphique en Lusitanie romaine", Varia Epigraphica (Atti del Colloquio Internazionale di Epigrafia, Bertinoro, 2000), Faenza, 2001, p. 237-248.

49 HÜBNER (Emílio), Noticias Archeologicas de Portugal, Lisboa, 1871, p. 12.

50 BEM (1718-1797): D. THOMAZ CAETANO DE BEM, Noticia das Thermas ou Banhos Cassianos e Outros Monumentos Romanos Modernamente Descobertos na Cidade de Lisboa (sem data).

TAVARES: Doutor Francisco Tavares (ca. 1750-1812), Instrucções e Cautelas Practicas sobre a Natureza, Differentes Especies, Virtudes em Geral e Uso Legitimo das Aguas Mineraes de Portugal..., Coimbra, Real Impr. da Universidade, 1810, p. 127.

RIBEIRO: Dissertaçoes Chronologicas e Criticas sobre a Historia e Jurisprudencia Ecclesiastica e Civil de Portugal publicadas por ordem da Academia R. das Sciencias de Lisboa pelo seu sócio João Pedro Ribeiro. Tomo IV. Parte I. Lisboa. 1819. 
ravam, por exemplo, a loba capitolina amamentando os gémeos, o Sol, esfinges e, sobre um nicho, um "tijolo de cor vermelha" com a inscrição. Aliás, há mesmo plantas desenhadas desse conjunto - que depois terá sido destruído para a construção do palácio do correio-mor - em que a inscrição se vê perfeitamente ${ }^{51}$ :

\section{A razão da pintura}

Outra dúvida restava, todavia: porque não fora tão imponente e minuciosa inscrição gravada em esbelta placa marmórea na fachada do edifício?

É que se estava já no século III. Os imperadores eram cada vez mais ciosos do seu poder - mormente porque sabiam quanto ele podia ser efémero... - e não permitiam, portanto, que 'outros' aparecessem sem que o seu nome também aí estivesse gravado. Ora, na verdade, a identificação do imperador (neste caso, seria Constantino) não estava contemplada na inscrição; por isso, em vez de figurar bem evidente no edifício, esta fora relegada para um lugar digno, frequentado, mas de certo modo discreto ${ }^{52}$, com apenas dois palmos de alto e três de largo!...

Tudo isso vinha, aliás, claramente expresso na legislação em vigor: determinava o Digesto (L, 10, 3) que, na epígrafe de um edifício público que não fosse circo, teatro ou anfiteatro, só poderiam constar o nome do imperador e a identificação de quem o financiara: "Inscribi autem nomen operi publico alterius quam principis aut eius cuius pecunia id opus factum sit non licet” ${ }^{53}$.

E, como se vê, é uma inscrição monumental-tipo: identifica o monumento (o que não é, naturalmente, nada frequente, porque as pessoas sabiam o que era um teatro, umas termas, um anfiteatro); menciona a razão por que nele se fizeram obras; quem as mandou fazer; quem delas se encarregou; e em que data. Não a poderíamos exigir mais completa nem mais elucidativa!

51 Por exemplo, Figueiredo (Borges de), "As thermas dos Cassios, em Lisboa", Revista Archeologica e Historica, p. 149-154, est. XII, que informa ter sido aquele 'rude esboço' retirado de um manuscrito da Biblioteca Nacional de Lisboa intitulado Collecção de varias inscripções romanas (a que também tive acesso). O pormenor do desenho que apresento é, porém, a reprodução da primeira informação dada desse monumento por Frei Manuel do Cenáculo. Agradeço ao Doutor Carlos Fabião e ao Dr. José Cardim Ribeiro a gentileza de mo haverem dado a conhecer e facultado.

52 Agradeço ao Doutor Marc Mayer esta observação.

53 Citado em José Carlos SAQUETE CHAMIZO, Las Elites Sociales de Augusta Emerita, Mérida, 1997, p. 112. 


\subsection{Outros documentos epigráficos}

\subsubsection{Inscrições em mosaicos}
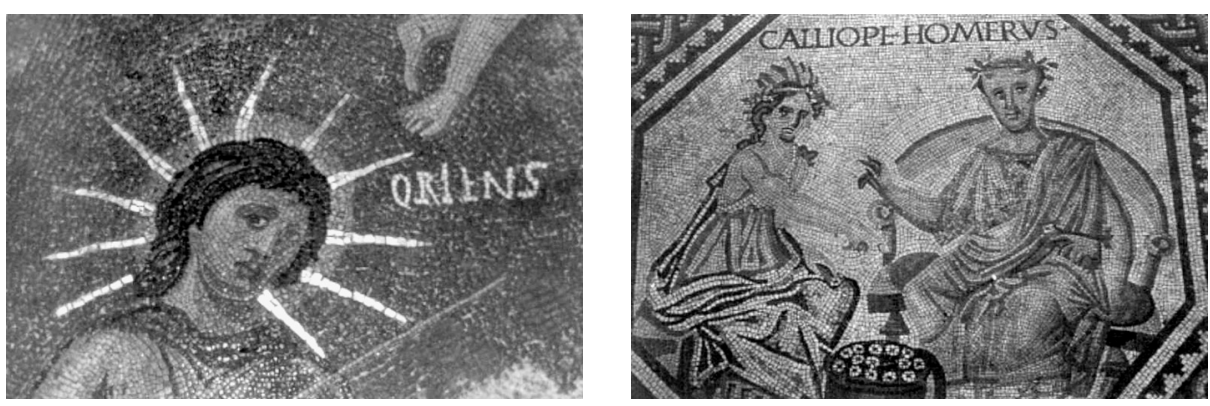

São diversos os tipos de inscrições que podem aparecer em mosaicos:

- legendas: nomes de divindades (as musas, por exemplo), nomes de pessoas (por exemplo, gladiadores ou aurigas célebres - Calimerus, Limenius...); animais (por exemplo, cavalos: Hiberus, Lenobatis...); ventos (Eurus, Boreas...); hidrónimos (Eufrates...)... O uso de legendas justifica-se mormente a partir do século IV, em que houve, por parte dos proprietários de villae, uma tentativa de fazer renascer os mitos antigos e, por isso, nem toda a gente compreenderia o significado das imagens.

- frases célebres: é bem conhecido o mosaico do Museu Arqueológico de Roma, a preto e branco, em que um esqueleto deitado aponta para a frase, em grego, "Conhece-te a ti mesmo".

- admoestações: Cave canem, na Casa do Fauno, de Pompeios, 'Cuidado com o cão!'; Scopa aspra tesselam ledere noli. Uteri f(elix)", 'Não estragues o mosaico com uma vassoura áspera. Felicidades!' - lê-se no mosaico das Musas de Torre de Palma.

- saudações e votos: como o vulgar uteri felix, atrás citado, num voto de felicidade e ventura; Omnia tibi felicia, "tudo de feliz para ti!», num mosaico patente no

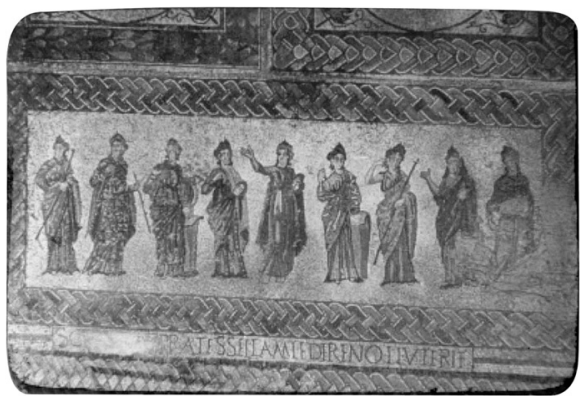


Museu do Bardo, em Túnis! Ou ainda, numa bem verosímil interpretação de J. Geraldes Freire do texto inserto num mosaico de villa Cardílio, em Torres Novas - Viventes Cardilium et Avitam felix turre - "A torre [no sentido de propriedade, villa] será feliz, enquanto viverem Cardílio e Avita"; ou dizendo de outra forma: "que tenham longa vida!".

- informativas: quando indicam, por exemplo, o nome do artífice (musivarius) que o fez (ex officina Anniponni); a cartela do mosaico do Oceano, de Faro, inclui-se também neste grupo, por indicar o nomes dos quatro magistri que se encarregaram de mandar 'atapetar' o solo com mosaico ${ }^{54}$.

- funerárias: mormente na época paleocristã, começam a ser frequentes os epitáfios feitos em mosaico: Honoratus in pace vixit annis... São inúmeros os exemplos em Ravena. E certamente um dos mais interessantes não deixará de ser a campa, qual leito nupcial de Septimia e Dionius, que se mostra no museu de Porto Torres, na Sardenha.

Refira-se que, amiúde, estas inscrições - por se destinarem a um ambiente restrito - se revestem de um certo carácter enigmático, como se o proprietário se divertisse a solicitar aos seus convidados: "Sabes o que isto quer dizer?". Nesse aspecto, nunca será de mais repetir quanto nos intriga o mosaico de Santa Vitória do Ameixial que apresenta um homem a fustigar uma mulher nua e que traz como legenda Felicio torritatus peior est quam ut cirdalus, que interpretei (IRCP 480) como: "Felicião enraivecido é pior que um carroceiro", mormente quando lhe não põem a água do banho a uma temperatura correcta!...

Por outro lado, detêm estas inscrições, sobretudo as que legendam cenas ou figuras mitológicas, importante valor cultural e pedagógico; além de constituírem relevante complemento para as informações arqueológicas e históricas.

O trabalho mais importante sobre inscrições em mosaicos da Península Ibérica é o de Joan Gómez Pallarès: Edición y Comentario de las Inscripciones sobre Mosaico de Hispania. Inscripciones no Cristianas, Roma, 1997.

54 Cf. IRCP 35; Janine LANCHA, "La mosaïque de l'Océan découverte à Faro (Algarve)", Conimbriga XXIV 1985 151-175. 


\subsubsection{Instrumentum}

As inscrições feitas em objectos de uso corrente agrupam-se, em Epigrafia, numa categoria a que se convencionou dar o nome de instrumentum. Existem em objectos de cerâmica e de metal.

São essas inscrições de dois tipos: as marcas de fabrico (frequentemente dentro de uma cartela, pois são resultado como que de um carimbo) e os grafitos.

As marcas de oleiro - EX OF(icina) MAELONIS, por exemplo, "da oficina de Melão" - apõem-se nas lucernas no fundo, do lado de fora; nas ânforas, na parte superior da asa; na terra sigillata, no fundo mas do lado de dentro.

Os grafitos surgem no bojo, em letra cursiva, gravados por estilete ou, por vezes, por meio de uma simples cana cortada, pois se fazem quando o barro ainda se não encontra bem seco. Depois da cozedura já o instrumento a usar terá de ser mais aguçado e rijo. Constituem os grafitos uma importante fonte para o estudo da vida quotidiana e da produção, na medida em que veiculam todo o tipo de informações, desde a capacidade de um recipiente, ao nome do proprietário, à identificação do conteúdo...

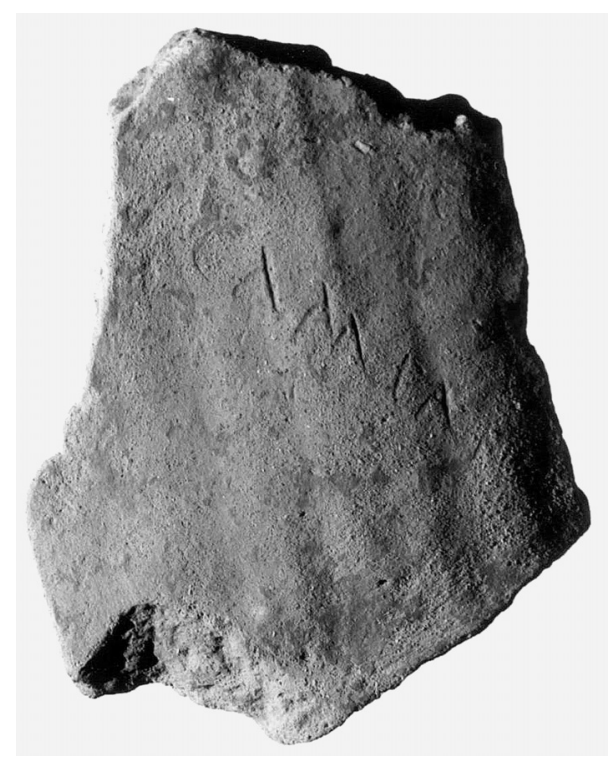

Tijolos e telhas raramente têm marcas, porquanto não trazem, à partida, publicidade ao fabricante, a não ser os fabricados por legiões, dado que essa é, por assim dizer, uma actividade oficial. Os grafitos que neles se fazem servem para numerações - várias se encontraram em Conímbriga -, para identificar o proprietário de um lote da fornada (Campani, que é como quem diz «aqui começa o lote de Campano"). Podem servir, por vezes, para alguma mensagem brejeira ou para uma saudação ocasional: AVE MAELO, "Eu te saúdo, ó Melão!", lê-se num tijolo de quadrante achado em Conímbriga (Melão era o proprietário 


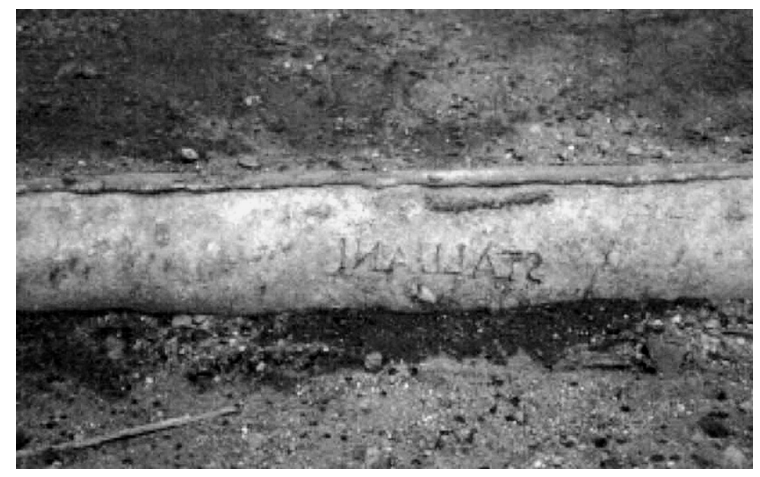

da olaria). Monique DondinPayre apresentou, a 20-111999, na Société Française d'Épigraphie sur Rome et le Monde Romain, de Paris, uma comunicação sobre inscrições em pesos de fusos de tear, onde a ambiguidade é, sem dúvida, rainha: "Imple me sic versa me", 'inebria-me e faz-me andar de cabeça à roda'; "Ave domina sitio", 'Olá, senhora! Morro de sede!”... 55

E há, depois, toda uma diversidade de inscrições, como a dos lingotes saídos das fundições; uma canalização de Évora (Ebora Liberalitas Iulia) traz a marca da cidade LIB.IVL; as canalizações de Pompeios ou de Roma registam o nome dos proprietários das casas a que se destinavam; as inscrições das pulseiras dos escravos ("tene me ne fugiam", "agarra-me para que não fuja”); as dos pesos, a atestar a sua aferição (ex pondus in Capitolio XI); em anéis podem ver-se as siglas V·F ('utere felix', 'felicidades!')... Interessantes, do ponto de vista medicinal, os 'carimbos' que identificavam os diferentes colírios para uso oftalmológico.

Facilmente se compreenderá que todo este rol de informações constitui importante manancial para o estudo da vida quotidiana, das correntes comerciais, da actividade económica em geral.

\subsubsection{Os miliários}

Tal como, na actualidade, temos os marcos quilométricos, também as vias romanas apresentavam miliários, assim designados por indicarem as milhas. Uma milha equivalia a mil passos, ou seja, aproximadamente, 1480

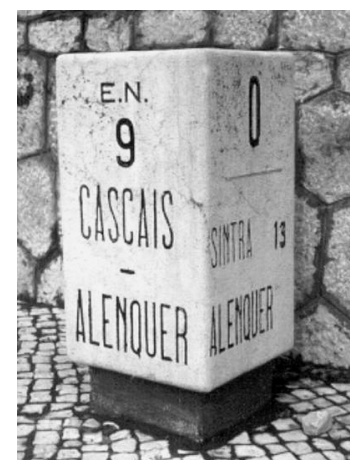

55 Monique DONDIN-PAYRE, "Épigraphie et acculturation: l'apport des fusaioles inscrites", in DESMULLIEZ (Janine), HOËT-VAN CAUWENBERGHE (Christine), Le Monde Romain à travers l'Épigraphie: Méthodes et Pratiques, Lille, 2005, 133-146. 
metros, daí que as siglas usadas fossem $\mathrm{M} \cdot \mathrm{P}=\mathrm{M}($ illia $)$ $\mathrm{P}$ (assuum), seguidas de um numeral. Não que houvesse miliários em todas as milhas; apenas existiriam em pontos-chave do percurso.

Fundamental numa inscrição miliária era a identificação do imperador durante cujo reinado aquele troço viário se fizera (nesse caso, os vocábulos viriam em ablativo) ou que supostamente interviera na sua execução ou reparação (o nominativo seria, então, o caso adoptado). No final, a indicação do número de milhas a que se encontrava da cidade, a partir da qual se começara a contagem (a chamada caput viae): A BRAC(ara) AVG(usta)

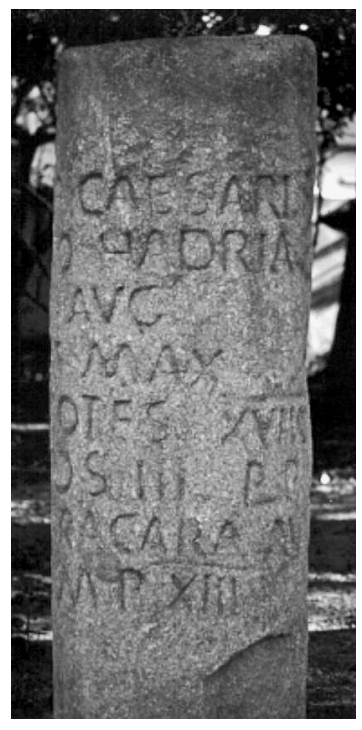
M $\cdot$ P $\cdot$ XVII - significava que o miliário fora colocada a 17 milhas de Braga.

Com metro e meio a dois metros de altura, o miliário assumia a forma cilíndrica para mais facilmente ser lido em andamento e, na sua paginação, houve o cuidado de colocar na perpendicular ao eixo da via os dados fundamentais para melhor se identificar o imperador e os demais elementos informativos essenciais ${ }^{56}$.

A partir do século III - conforme preconizou Pierre Salama ${ }^{57}$ - os miliários deixam de ter uma função predominantemente informativa para serem também - e, quiçá, fundamentalmente - um acto de homenagem ao imperador, cuja identificação passa a estar, por isso mesmo, em dativo. Compreende-se: a paisagem urbana epigráfica estava a ficar saturada; a vida nas cidades deixara de ter encanto e, por outro lado, eram os caminhos assaz frequentados e resultava, assim, mais omnipresente e mais relembrada a autoridade imperial. Daí que, como muito bem frisou Elena Banzi ${ }^{58}$, os miliários tenham exercido, de facto, uma função dupla: de indicadores de caminhos e de instrumentos de propaganda, donde resulta serem fontes importantes para o estudo da topografia e -

\footnotetext{
56 Tive ensejo de chamar a atenção para esse facto no texto "Miliários da Geira: informação e propaganda", Cadernos de Arqueologia 12-13 1995-1996 39-43.

57 In Bornes milliaires d'Afrique Proconsulaire - Un Panorama Historique du Bas Empire Romain, Paris, 1987.

58 I Miliari come Fonte Topografica e Storica, Paris (De Boccard), 1999.
} 
também - da história. Daí que, na Geira (seguramente, uma das zonas do mundo romano com maior densidade de miliários), se encontrem no mesmo local diversos miliários, de imperadores diferentes...

\subsubsection{Os termini}

Conhece-se a lenda: Rómulo traçou com o sulco de um arado o perímetro da cidade de Roma, envolvendo tudo num ritual sagrado. Por ter violado esse limite, Remo foi assassinado. A delimitatio, a marcação dos limites, teve sempre entre os homens um carácter quase sobrenatural. Desrespeitá-los, 'passar os limites' tinha sanções humanas e divinas.

Em Roma, numa primeira atitude de consciência urbanística, salvaguardou-se de imediato o leito de cheia do rio Tibre, com marcos rigorosamente colocados nas margens, a fim de que não houvesse a tentação de aí se edificar. Já tivemos ocasião, a propósito dos 'erros' epigráficos de observar o texto desses marcos, onde a cono-

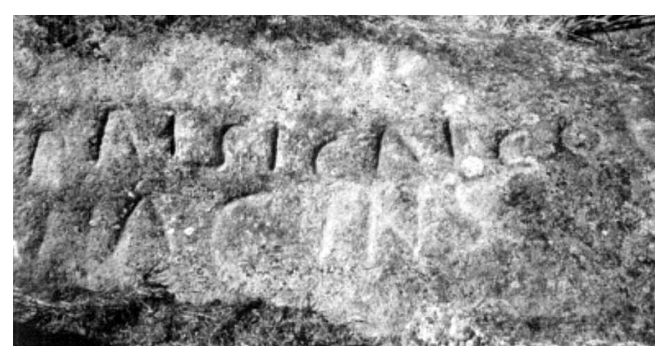
tação religiosa é primacial: tanto a palavra Augustus como o título pontifex maximus aí figuram por extenso... É o imperador, sim, mas na sua dupla qualidade de chefe terreno e de representante das divindades..

Quando alargaram o seu território, tiveram os Romanos o cuidado de traçar limites, de respeitar limites anteriores... Por isso se encontram, por exemplo na região das Beiras actuais, inscrições rupestres que assinalam o território deste ou daquele povo, para que o usufruto das águas e das terras ficasse a contento de todos. E quando havia problemas, lá estava o legado imperial para os resolver ${ }^{59}$. Os termini augustales, desde que encontrados no sítio original - o que, infelizmente, raro acontece - proporcionam, pois, relevante contributo para a determinação do território dos diversos povos que habitaram uma região. Sabemos, por

59 Cf. a recensão que fiz (in Conimbriga 231984 221-223) a G. FATÀS, Contrebia Belaisca (Botorrita, Zaragoza) - II - Tabula Contrebiensis, Saragoça, 1980. 
exemplo, por uma inscrição da ponte de Alcântara, que vários eram os povos pré-romanos dessa zona da Beira Interior; a questão está, hoje, em lograr determinar-lhes os territórios e as cidades que porventura lhes serviram de capitais.

Conhece-se, nesse âmbito, um marco delimitatório achado em Peroviseu de que há, em meu entender, uma cópia no Museu Municipal de Fundão onde, expressamente, após a identificação do imperador Augusto, a datar o acto do período entre 1 de Julho do ano 4 e 30 de Junho de 5, se assinala ser aquele o terminus augustalis inter Lancienses et Igaeditanos ${ }^{60}$. Era um acto público, presidido certamente por um representante imperial e a sua colocação in situ resultava, sem dúvida, de amplas negociações...

Igualmente se serviam da Epigrafia os funcionários imperiais encarregados, por exemplo, da distribuição de terras a colonos. Os 'cadastros' são documentos que, além de alguma topografia simplificada das regiões em apreço, trazem outras indicações como o nome da pessoa a quem determinada parcela foi adjudicada. Os cadastros mais citados são, sem dúvida, os da colónia de Orange, sobre que existe inúmera bibliografia, a partir do momento em que foram dados a conhecer por Piganiol ${ }^{61}$.

\subsubsection{Textos jurídicos}

Diversas são as tábuas de bronze recentemente encontradas que integravam leis municipais, fonte primacial para a reconstituição do modo de vida das populações e, sobretudo, da forma como em cada município e colónia se procurava imitar a vida administrativa romana. Fala-se da Lex Malaccitana, da Lex Salpensana, das cinco tábuas da Lex Coloniae Inmunis Genetivae Iuliae Urbanorum, do bronze de Italica, da Lex Irnitana, da Tabula Alcantarensis, do bronze de Bembibre ${ }^{62} \ldots$ Na verdade, na Península Ibérica, designadamente na

\footnotetext{
${ }^{60}$ Cf. o que escrevi, sobre "Epigrafia e território", in Espacio, Tiempo y Forma, série II, 10, 1997, 79-89. Sobre este marco: Conimbriga XVI 1977 p. 27-29.

${ }^{61}$ A. PIGANIOL, Les Documents cadastraux de la colonie romaine d'Orange, Paris, 1962.

${ }^{62}$ Luis GRAU y José Luis HOYAS (eds.), El Bronce de Bembibre - Un edicto del emperador Augusto - Museo de León, Junta de Castilla y León, 2001.
} 
Bética, os achados têm-se multiplicado, trazendo nova luz à orgânica municipal dos Romanos 63 .

António Caballos, no texto citado, enumera também outros documentos epigráficos de bronze provenientes da Península Ibérica.

As tabulae patronatus ou tesserae hospitales, por exemplo, como que 'antepassados' dos pactos de vassalagem medievais, em que uma família se coloca certamente por motivos políticos e económicos - sob a protecção de uma outra $^{64}$. São várias as encontradas inclusive em território nacional ${ }^{65}$, de que se exemplifica (com a tradução) uma identificada em Juromenha (IRCP 479):

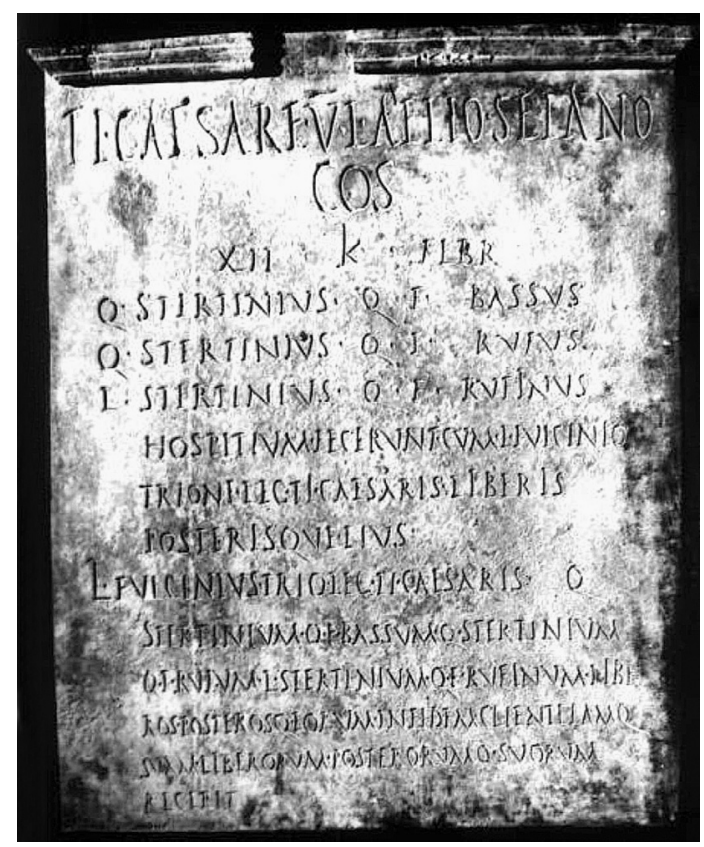

63 Para além do livro, já clássico, de Álvaro d’Ors, sobre a epigrafia jurídica da Hispânia romana, datado de 1953, outros estudos se têm desenvolvido. Vejam-se, a título de exemplo, as actas do colóquio internacional realizado em Pamplona em Abril de 1987: Epigrafía Jurídica Romana, Pamplona, 1989. E a notável síntese de Antonio CABALLOS RUFINO, "Las fuentes del Derecho: la epigrafía en bronce" no catálogo da exposição Hispania - El Legado de Roma, patente, por exemplo, no Museo Nacional de Arte Romano de Mérida (Fev/Abril 1999), p. 205-221.

64 Cf. John NICOLS, "Tabulae patronatus: a Study of the Agreement between Patron and Client Community", Aufstieg und Niedergang der Römischen Welt, II 13, Berlim / Nova Iorque, 1980, p. 535-561.

65 Cf. SILVA (A. C. E), "As tesserae hospitales do Castro da Senhora da Saúde ou Monte Murado (Pedroso, Vila Nova de Gaia) - Contributo para o estudo das instituições e povoamento da Hispânia Antiga", Gaya 11983 9-26. Ver também: ÉTIENNE (Robert), LE ROUX (Patrick) e TRANOY (Alain), "La tessera hospitalis, instrument de sociabilité et de romanisation dans la Péninsule Ibérique", Sociabilité, Pouvoirs et Société (Actes du Colloque de Rouen, 24/26 Novembre 1983), Rouen, 1987, p. 323-336. 
"Aos doze dias antes das calendas de Fevereiro [21 de Janeiro] do ano em que foram cônsules Tibério César, pela quinta vez, e Lúcio Élio Sejano [31 d. C.], Quinto Estertínio Basso, filho de Quinto, Quinto Estertínio Rufo, filho de Quinto, Lúcio Estertínio Rufino, filho de Quinto, fizeram um pacto de hospitalidade com Lúcio Fulcínio Trião, legado de Tibério César, seus filhos e descendentes. Lúcio Fulcínio Trião, legado de Tibério César, aceitou tal preito de fidelidade e recebeu como seus clientes - e de seus filhos e descendentes - Quinto Estertínio Basso, filho de Quinto, Quinto Estertínio Rufo, filho de Quinto, Lúcio Estertínio Rufino, filho de Quinto, assim como seus filhos e descendentes".

Uma placa de bronze, que terá sido encontrada na freguesia de Alvega e de que se perdeu o rasto, traz o designado iusiurandum Aritiensium ao imperador Calígula, eco muito provável dos juramentos com que, em circunstâncias específicas do Império, as comunidades proclamavam a sua fidelidade ao poder central, tal como, de resto, o próprio Augusto, nas suas Res Gestae ${ }^{66}$ o dá a entender ter começado a ser hábito. Dele fiz a seguinte tradução (IRCP 647):

«Sendo Gaio Umídio Dúrmio Quadrado legado propretor do imperador Gaio César Germânico - juramento dos Aricienses:

"Que, em minha consciência, serei inimigo daqueles que eu souber que o são de Gaio César Germânico; e se alguém o põe ou puser em perigo, a ele ou ao seu bem-estar, não me cansarei de o perseguir, pelas armas, em guerra de morte, na terra e no mar, até lhe aplicar o castigo; nem estimarei mais os meus filhos do que a vida dele; considerarei meus inimigos aqueles que o hostilizarem. Se, conscientemente, falto ou vier a faltar ao juramento, então que Júpiter Óptimo Máximo e o divino Augusto e todos os outros deuses imortais me privem, a mim e a meus filhos, da pátria, da segurança pessoal e de toda a boa sorte".

\footnotetext{
66 As Res Gestae Divi Augusti são, também elas, um documento epigráfico. Veja-se a sua tradução em Maria Helena da Rocha PEREIRA, Romana - Antologia da Cultura Latina, Universidade de Coimbra, ${ }^{4} 2000$, p. 109-121. Dentre os multíplices estudos feitos sobre o tema, refiram-se dois dos mais recentes, que vêm sintetizados em AE 1999, 1609 e 1610.
} 
No quinto dia antes dos idos de Maio [11 de Maio], na cidade velha de Arício, sendo cônsules Gneu Acerrónio Próculo e Gaio Petrónio Pôncio Nigrino [37 d. C.] e magistrados Vegeto, filho de Táltico, e Víbio, filho de [...].”

Documentos epigráficos ímpares no território português são as duas tábuas de Aljustrel. Ainda que parcelares, trazem informação preciosa, uma sobre a vida quotidiana numa aldeia (vicus) cuja actividade primordial era a exploração mineira (minérios de cobre e ferro), outra sobre pormenores técnicos e normas de segurança a praticar na mineração ${ }^{67}$.

Não se identificaram, até ao momento, diplomas militares no território actualmente português. Trata-se, no entanto, de um dos documentos mais interessantes do ponto de vista da história militar romana. Após ter prestado o serviço militar, o soldado - honesta missione, "missão cumprida com honra" - recebia um "diploma' que lhe conferia todos os direitos civis e políticos. Geralmente, o documento referia-se a todos os elementos que tinham sido alistados em determinado corpo militar. No Museu de Sassari, por exemplo, mostra-se o que foi outorgado por Galba, em 69 d. C. aos veteranos que militaram na I Legião Adiutrix ${ }^{68}$. Concede-lhes a bonesta missio e o direito de cidadania (civitas) a eles, aos filhos e aos descendentes deles, acrescentando uma concessão importante em relação ao casamento: conubium cum uxoribus quas tunc habuissent cum est civitas iis data aut si quis caelibes essent cum is quas postea duxissent dum taxat singuli singulas; ou seja, era-lhes outorgado o direito de legalizarem o matrimónio com as mulheres

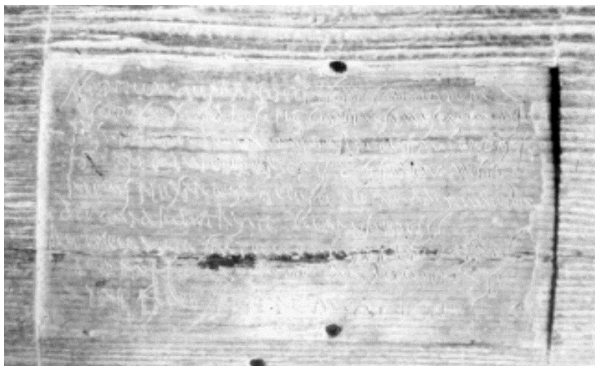
com quem já viviam maritalmente, às quais também se concedia o direito de cidadania; caso fossem solteiros, esse direito era concedido em relação àquelas com quem viessem a casar, desde que cada um escolhesse uma.

\footnotetext{
${ }^{67}$ Resumi o que sobre esses dois documentos se sabia nas IRCP sob os números IRCP 142 e 143 e traduzi-os. Para além do trabalho de Claude Domergue "La mine antique d'Aljustrel (Portugal) et les tables de bronze de Vipasca", Conimbriga 221983 1-205, cf. Sergio LAZZARINI, Lex Metallis Dicta (Studi sulla Seconda Tavola di Vipasca), Roma, 2001.

${ }^{68}$ Citado, aliás, por Raymond BLOCH, L'Épigraphie Latine, PUF, Paris, ${ }^{3} 1964$, p. 92.
} 
Uma referência ainda aos contratos de compra e venda e outros, geralmente gravados com estilete em tabuinhas enceradas (tabulae ceratae). São mais frequentes na zona oriental do Império ${ }^{69}$.

\subsubsection{Tabellae defixionum}

O achado recente de um documento deste tipo em Alcácer do Sal ${ }^{70}$ leva-nos a pensar que outros se poderão encontrar.

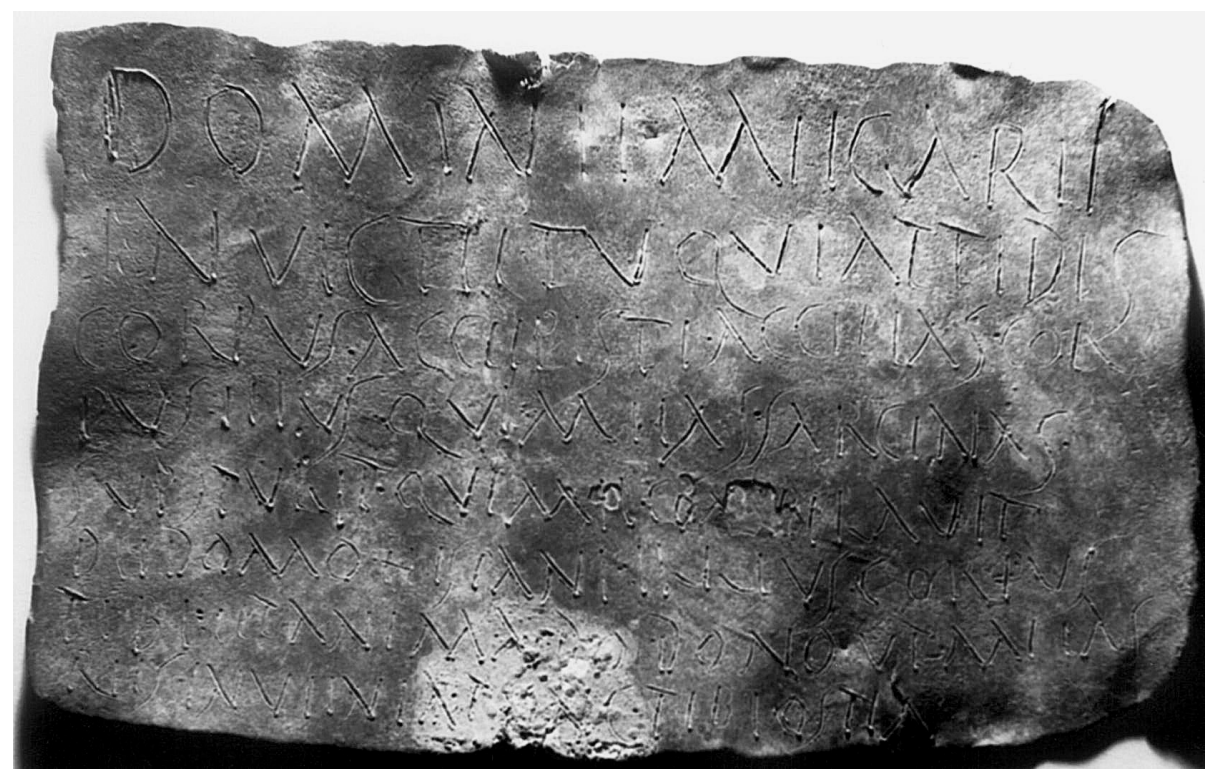

Gravados em folhas de chumbo, para mais facilmente se dobrarem, esses textos (por vezes, escritos ao revés, de forma que só poderiam ser lidos diante de um espelho...) invocavam divindades a fim de fazerem um 'feitiço' sobre determinada pessoa a quem se desejava bem ou, sobretudo, mal. No caso de Alcácer do Sal, invoca-se Átis e Cíbele para que amaldiçoem um ladrão e façam

69 Cf., p. e., Ioan I. RUSSU, Inscriptiile Daciei Romane, I, Bucareste, 1975, p. 165-256.

70 Vide José d'ENCARNAÇÃO e João Carlos Lázaro FARIA, "O santuário romano e a defixio de Alcácer do Sal", Religiões da Lusitânia - Loquuntur Saxa, Museu Nacional de Arqueologia, Lisboa, 2002, p. 259-263. Achegas de leitura e interpretação já foram dadas por Amílcar GUERRA, "Anotações ao texto da tabella defixionis de Alcácer do Sal", Revista Portuguesa de Arqueologia, vol. 6, no 2, 2003, p. 335-339; e por Francisco Marco Simón, "Magia y cultos orientales: acerca de una defixio de Alcácer do Sal (Setúbal) con mención de Atis", MHNH 42004 79-84. 
com que restitua o fruto do roubo. Mas intuitos amorosos serão, sem dúvida, os mais frequentes como o serão também outros, num outro registo de paixão: as corridas de cavalos! Encontraram-se placas de chumbo sob os hipódromos encomendando à maldade dos deuses infernais o auriga X ou o cavalo $\mathrm{Y}$, para que não saísse vencedor, em detrimento daqueloutro que era o favorito.

"Amarrotadas", essas placas eram, amiúde, colocadas também em buracos feitos nas sepulturas ${ }^{71}$, pois se acreditava que os defuntos seriam os melhores mensageiros da desgraça ou do bom augúrio!

\subsubsection{As tésseras}

Pequenos objectos do quotidiano (de bronze, de chumbo, de cerâmica...) podiam igualmente ter inscrições, como hoje acontece. Assim, poderemos encontrar, por exemplo:

- tesserae lusoriae: dados para jogo;

- tesserae frumentariae: senhas para receber alimentos ${ }^{72}$;

- tesserae conviviales: convites para banquetes ou refeições;

- tesserae theatrales: o equivalente ao actual bilhete com indicação do lugar...

\footnotetext{
71 "Geralmente de pessoas jovens que tinham morrido assassinadas ou de justiçados, para aproveitar o ressentimento da sua larva, que se conservava no túmulo", explicita Ana María Vázquez Hoys, in Arcana Magica (Diccionario de símbolos y términos mágicos), UNED, Madrid, 2003, p. 517.

72 Cf. Catherine VIRLOUVET, Tessera frumentaria (Les procédures de distribution du blé public à Rome à la fin de la République et au début de l'Empire), Paris, 1995.
} 
A PRÁTICA DO EPIGRAFISTA 
(Página deixada propositadamente em branco) 


\section{AUXILIARES DE LEITURA}

\subsection{A fotografia}

Uma boa fotografia pressupõe cuidada limpeza do monumento, de forma que se notem bem os sulcos das letras. Uma escova (não muito rija) e um pouco de água são muitas vezes suficientes. Para eliminação dos líquenes, há que recorrer a técnicos especializados, para que não se deteriore o suporte. Se se procedeu à sua lavagem, deixe-se secar o monumento, a fim de evitar reflexos. Nunca se devem avivar as letras com giz, carvão ou de qualquer outro modo - tal prática induz a frequentes erros de leitura.

Feita ao sol, a fotografia só será boa se o monumento se puder orientar em relação aos raios solares, que deverão nele incidir obliquamente. A dificuldade em movimentar assim os monumentos tem levado a adoptar, com êxito, a fotografia com luz artificial.

Devem colocar-se duas lâmpadas, uma de cada lado, mais ou menos rasantes e, se forem da mesma intensidade, a igual distância do monumento. A orientação dos focos requer cuidado especial e é sempre preferível que sejam duas pessoas a fazê-la: enquanto uma se coloca diante do monumento para detectar quando se atingiram as condições óptimas de iluminação, a outra movimenta os focos luminosos.

Convém que todos os pormenores do monumento, e sobretudo do texto, se distingam, mas deve evitar-se, por outro lado, qualquer chapada de luz: procurar-se-á que a iluminação seja homogénea. 
A fim de que os contornos do monumento se destaquem, no fundo e lateralmente colocar-se-ão panos brancos ou pretos, bem esticados, para que as dobras não se notem.

Fotografias com flash só muito raramente resultam.

Fotografar monumentos epigráficos requer bastante prática e não há que desanimar, se as primeiras experiências falharem.

Devido à pátina que os materiais apresentam e ao possível contacto superficial com substâncias colorantes, a fotografia, para efeitos de estudo e de publicação, não deve ser a cores.

A "reportagem" fotográfica há-de ser completa; assim, pormenores dos elementos decorativos deverão ser também fotografados.

Dado que se apresentam as dimensões, não é absolutamente imprescindível colocar junto do monumento uma escala graduada. Se tal for possível, melhor.

Podem obter-se boas cópias (mesmo em 18 x 24) com filmes de $35 \mathrm{~mm}$. Todavia, os negativos $6 \times 6$ ou $6 \times 9$ oferecem maiores possibilidades de se conseguir uma boa reprodução. A escolha do papel de impressão é igualmente importante: convém pedir que o laboratório utilize papel branco de contraste. A fotografia duma inscrição difere muito da fotografia duma paisagem ou dum instantâneo: alerte-se o laboratório para a natureza do trabalho entregue.

O uso generalizado de máquinas digitais, com a possibilidade de se verificar, no instante, o que se fotografou, veio facilitar em muito a tarefa do epigrafista. E, doravante, os cuidados maiores a ter situam-se ao nível da resolução das imagens, a fim de que - em caso de reprodução em papel - se logre obter uma leitura nítida.

\section{2 O decalque}

Quando um texto oferece dificuldades de leitura, o decalque surge como técnica aconselhável. Há vários processos, mas o menos sofisticado era o decalque com papel mata-borrão, tipo de papel que deixou de fabricar-se. Em todo 
o caso, como certamente aparecerão no mercado produtos com idêntica consistência e que, eventualmente, poderão vir a servir para este fim, mantenho as informações que habitualmente se davam neste procedimento.

Limpa-se o monumento muito bem e molha-se totalmente a superfície a decalcar. Embebe-se o mata-borrão em água (com cuidado para não rasgar) e aplica-se ao monumento. Com os dedos, ajusta-se o mata-borrão, sem rasgar, $a$ todas as reentrâncias do monumento, de modo a obter-se o texto em negativo. Desta operação depende o êxito do decalque, pelo que se recomenda que toda a superfície seja minuciosamente explorada; é por isso também que preferimos o uso dos dedos, mais sensíveis a todos os acidentes.

Depois, basta deixar secar: o mata-borrão cairá por si. Tenha-se, contudo, cuidado na maneira de o transportar; às vezes, uma simples falta de atenção inutiliza todo um trabalho paciente.

Para a leitura, o decalque oferece a rara vantagem de poder ser lido dos dois lados.

O decalque de marcas de oleiro faz-se com grafite e papel de mortalha. Aplica-se a mortalha sobre a marca e passa-se com a grafite repetidas vezes até se reproduzirem as letras.

\section{O ESTUDO DE UM MONUMENTO EPIGRÁFICO}

Embora pensadas, de modo especial, para os casos das epígrafes romanas, as normas que a seguir se explanam servem também para monumentos de todas as épocas, pois os elementos a colher do monumento epigráfico como fonte histórica não variam consoante a época a que o monumento se reporta.

\subsection{Dados a incluir}

O monumento epigráfico deve ser estudado o mais integralmente possível, sobretudo se inédito. 
Começar-se-á por apresentar uma fotografia ou, caso esta seja difícil de obter, um desenho. Se o monumento fizer parte dum núcleo que vai estudar-se, atribuir-se-lhe-á um número (árabe, de preferência).

O esquema a adoptar incluirá:

- tipologia (ara, estela, placa, pedestal, miliário...);

- material (calcário, mármore, granito, bronze...);

- local de achado (lugar, freguesia, concelho, desgarrado ou não dum contexto arqueológico);

- paradeiro.

Poderá dar-se, desde logo, a entender que tipo de inscrição contém. Tudo isso pode ser resumido numa simples frase inicial: "Árula funerária de calcário branco, encontrada em Faro e guardada no Museu Nacional de Arqueologia (N. o de entrada: E 6435". Quando a peça está num museu, convém indicar sempre o seu número de inventário.

A seguir:

- descrição;

- dimensões;

- leitura interpretada;

- tradução;

- altura das letras e dos espaços interlineares;

- bibliografia, por ordem cronológica (ou a indicação "inédita");

- variantes de leitura (em relação à apresentada, indicadas linha a linha, com o nome do autor entre parênteses);

- comentário paleográfico (paginação, gravação);

- comentário histórico.

\subsection{As medições}

As medidas costumam apresentar-se em centímetros. São as dimensões máximas, dadas na seguinte ordem: altura x largura $\mathrm{x}$ espessura. Use-se fita 
métrica e régua para obter os alinhamentos, nomeadamente em monumentos de formato irregular.

Numa ara é útil dar isoladamente a largura e a espessura da cornija, do fuste e da base. Quando houver elementos decorativos, medir-se-ão também.

Do campo epigráfico, tiram-se as medidas interiores: altura x largura. Observe-se bem onde é que realmente acaba a moldura e começa o campo epigráfico propriamente dito. Quando a inscrição ocupa toda a face do fuste duma ara, por exemplo, o campo epigráfico mede-se desde a parte inferior do capitel até à parte superior da base.

Das letras, deve dar-se a altura máxima: ou seja, como são geralmente gravadas em bisel, hão-de medir-se desde o arranque do corte superior até à parte inferior do corte inferior, na perpendicular. De um modo geral, as letras apresentam, linha a linha, dimensões homogéneas; caso o não sejam, medir-se-á a maior e a menor e indicar-se-ão as medidas máxima e mínima (não é preciso dar a medida de todas). Não confundir, porém, essa eventual irregularidade com a utilização consciente de pequenas e grandes letras por parte do ordinator. Sempre que tal aconteça, tomar-se-ão as medidas dumas e doutras. Assim:

Altura das letras: 1. 1: 2,2; 1. 2: 2/2,3 (C=1, I=2,7); 1.3 a 6: 2,2; 1. 7: 2.

Os espaços interlineares (não "interliterais") devem também ser medidos, porque poderão ajudar a caracterizar uma oficina. Atenda-se ao que se disse acerca das medições das letras e do campo epigráfico, porque o espaço 1 é medido desde a parte superior do campo epigráfico até às letras da 1. 1; o espaço 2 entre as 1.1 e 2, e assim por diante, até ao espaço entre a última 1. e a parte inferior do campo epigráfico, de sorte que há sempre mais um espaço interlinear que linhas. Aqui também se terá o critério adoptado para as letras irregulares: dá-se a medida máxima e a mínima. Assim:

Espaços: 1: 2; 2 a $4: 1 ; 5: 0,8 / 1 ; 6: 1 ; 7: 4$. 


\subsection{A descrição}

A descrição deve ser feita de cima para baixo e da esquerda para a direita.

Se não conhecer bem a terminologia a adoptar na descrição de aras, de molduras, da decoração, sugerimos que a descrição se não perca em pormenores até porque se pressupõe a existência duma boa fotografia a acompanhar o texto.

Por exemplo, no caso duma ara, importa dizer como é o capitel: forma do fóculo, ladeado ou não por toros (lisos ou trabalhados), com ou sem frontão adiante; se a molduração é feita nas quatro faces (o que nos pode dar a saber se o monumento se destinava a ser visto em todas as faces); se o campo epigráfico tem moldura, se é rebaixado em relação a ela, se foi polido; se há decoração lateral (o jarro, a pátera) ou na retaguarda (aspecto que muitas vezes se esquece).

\subsection{A leitura}

A não ser que se veja nisso uma real vantagem, não é necessário apresentar o texto em caracteres epigráficos, como vem no monumento.

Assim, a leitura implica a interpretação, com desdobramento de siglas e abreviaturas e a reconstituição do que falta.

Aqui, há regras a fixar ${ }^{1}$ :

- o texto epigrafado é dado sempre em maiúsculas (V sempre V mesmo que tenha valor de U);

${ }^{1}$ Estas são as regras que - por terem sido adoptadas com êxito no volume II das Fouilles de Conimbriga - eu preconizo. Afiguram-se-me de muito fácil apreensão, por parte do leitor, daquilo que está na epígrafe e do que nela não figura. Daí a adopção de maiúsculas. Por outro lado, a fim de poupar espaço e porque se tem foto ou desenho a mostrar como as linhas estão dispostas, não vejo necessidade de se manter, na leitura, a disposição linear do monumento, apresentando o texto seguido, como quando se cita poesia e se assinala por um traço a divisão dos versos.

Anote-se, porém, que outras regras há, inclusive de cunho internacional, e que podem, por isso, ser adoptadas. Controversa é, por exemplo, não o nego, a opção pela grafia $\mathbf{v}$ em vez do u, em minúsculas; penso que evita confusões, embora... aceite a diferença! Apenas se deve sublinhar que os critérios seguidos deverão sê-lo ao longo de todo o artigo ou livro e convirá assinalar, no início, o significado dos sinais diacríticos utilizados. 
- o desdobramento das siglas e abreviaturas é feito entre parênteses curvos e em itálico;

- colocam-se entre parênteses rectos e sempre em maiúsculas os caracteres que supomos terem sido gravados e que actualmente, por qualquer motivo, já se não vêem;

- sob as letras incompletas no texto, mas reconstituíveis com maior ou menor dúvida, põe-se um ponto;

- a separação das linhas é assinalada por uma barra; numeram-se no começo as linhas múltiplas de 5 . Se a translineação cortar uma palavra, não se deixa espaço entre as letras e essa barra. Se, por necessidade nossa, houver que cortar uma palavra na mudança de linha, usa-se o hífen, como é habitual;

- indica-se a pontuação existente, se possível a meio da linha, como vem na epígrafe (recorrendo aos 'símbolos' do computador); se for uma hera, escreve-se: (hedera) ou pode, também, recorrer-se a símbolo idêntico disponível no computador.

- quando uma reconstituição nos parecer duvidosa, assinalemo-lo com: ?;

- se se desconhecem as letras ou linhas que faltam, indica-se: [...], reservando para o comentário paleográfico a informação de quantas letras ou linhas supomos possíveis ${ }^{2}$;

- após os numerais, convirá pôr por extenso, em latim, o seu valor, até porque uma vezes se lêem como cardinal, outras como ordinal ou, ainda, adverbial;

- os nexos indicam-se sobrepondo um arco ou um traço às letras neles envolvidas ${ }^{3}$.

À leitura seguir-se-á a tradução. Há quem prefira manter em latim os antropónimos; nós preconizamos que se traduzam, atendendo-se às regras linguísticas.

\footnotetext{
${ }^{2}$ Há quem prefira pôr tantos hífenes quantas as letras que supõe terem existido; ou ainda um numeral entre dois hífenes a assinalar o número de caracteres que se considera faltarem.

${ }^{3}$ Há outras formas de assinalar os nexos; convirá, pois, verificar qual o critério adoptado pelo autor.
} 


\section{Exemplos:}

1) DIS (hedera) MAN(ibus) / LVPA · $\mathrm{AN}($ norum) / II (duorum) $\cdot \mathrm{M}($ ensium) $\cdot \mathrm{X}($ decem $) \cdot \mathrm{D}$ (ierum) $\mathrm{XV}$ (quindecim)

Aos deuses Manes. Lupa, de dois anos, dez meses, quinze dias.

2) $\mathrm{D}($ is $) \cdot \mathrm{M}$ (anibus) $\cdot \mathrm{S}$ (acrum) / ANNIA MATER $\overline{\mathrm{NA}} \cdot \mathrm{ANN}$ (orum) L (quinquaginta $) / \mathrm{H}($ ic $) \cdot \mathrm{S}($ ita $) \cdot \mathrm{E}($ st $) \cdot \mathrm{S}($ it $) \cdot \mathrm{T}($ ibi $) \cdot \mathrm{T}($ erra $) \cdot \mathrm{L}($ evis $)$

Consagrado aos deuses Manes. Aqui jaz Ânia Materna, de cinquenta anos. Que a terra te seja leve.

3) [L]VCIV[S] / [L]ICINIV!/S FVSCVS $\cdot \mathrm{H}($ ic $) \cdot \mathrm{S}($ itus $) \cdot[\mathrm{E}($ st $)] /[\ldots]$ ? Aqui jaz Lúcio Licínio Fusco...

\subsection{O comentário}

Costumamos designar por comentário paleográfico o que se debruça sobre o modo como o texto foi paginado e gravado (tipo de letras, características do traçado dalgumas delas). Também aqui - se há uma boa fotografia - não interessa que nos percamos em demasiados pormenores; basta cingir-nos apenas aos mais significativos.

Ao comentário bistórico - justamente por ser através dele que se faz o aproveitamento da Epigrafia como fonte para a História - convirá dar a máxima atenção.

Se o monumento em si - sua monumentalidade, sua decoração - e o contexto arqueológico em que foi encontrado não nos podem deixar indiferentes, sobre o texto é que se concentrará o nosso comentário: fórmulas, antropónimos (sua frequência na Península Ibérica e no mundo romano, seu significado...), teónimos, concisão ou prolixidade - tudo será passado a pente fino.

O comentário requer prática epigráfica e bons conhecimentos históricos; se, como já atrás se disse citando Raymond Bloch, o historiador da Antiguidade Clássica - e o de todas as épocas, afinal! - deve ter uma pontinha de epigrafista, o epigrafista terá de ser forçosamente historiador. Tal não se consegue de um 
dia para outro, mas importa começar. E, neste aspecto, dois perigos se hão-de ter em conta: 1) o limitar-se a amontoar dados sem deles tirar qualquer ilação e 2) as generalizações precipitadas.

Ilustremos este ponto com o comentário que fizemos ${ }^{4}$ à placa funerária 189 dedicada pela mulher, Árria Quintila, e pela filha, Avita, a Valério Máxumo, falecido com 80 anos. Pode também mostrar como nem sempre o comentário histórico é forçosamente mais extenso que o paleográfico.

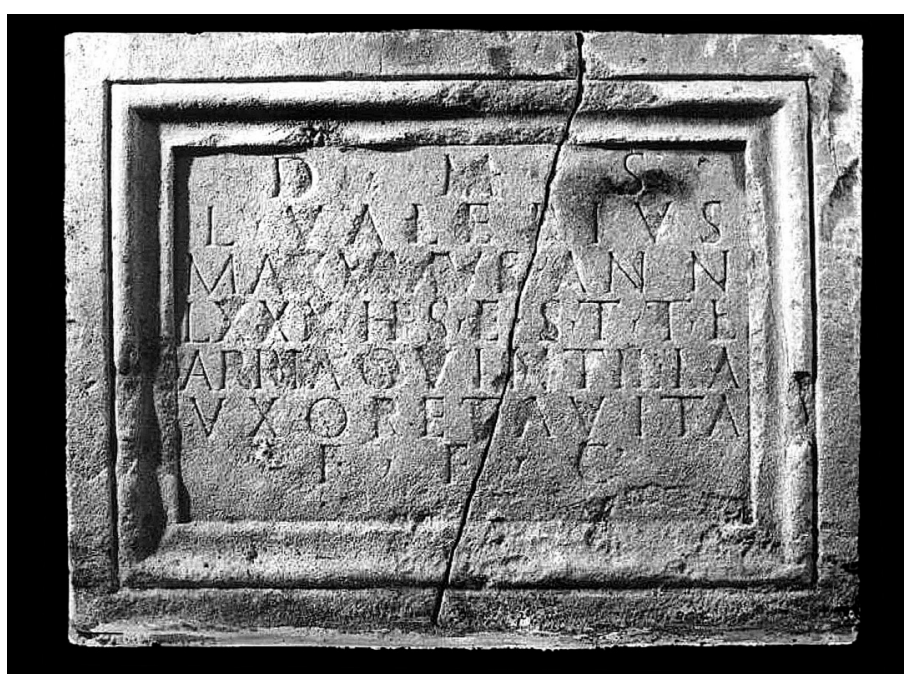

"Paginação muito cuidada, notável distribuição das letras no espaço epigráfico, mesmo que o ordinator tenha sido forçado, no final da 1. 3, a distanciar um pouco os NN, o que, aliás, acontece também na 1. 6. A pontuação, elegante, é constituída por sinais em jeito de Y, levemente delineados, arqueados. Apesar das falhas, o exame atento permite apercebermo-nos dum traçado regular da letra, capital quadrada, bem geométrica e proporcionada - um caso em que a paleografia (nomeadamente pela forma do R, do D, do M) sugere uma datação de começos do século II.

Todos os nomes são perfeitamente latinos, muito comuns. Será curioso aproximar desta placa uma outra, de Lisboa (ILER 4759 = SILVA 102), que apresenta duas dedicantes também: Arria Quintilla e Lucretia Avita."

\footnotetext{
${ }^{4}$ In Conimbriga XVI 1977 p. 72-73. IRCP 470.
} 
É no comentário histórico que se fará uso mais frequente da bibliografia. Nenhuma afirmação pode ser gratuita; nenhum autor poderá ser citado, sem que dele se dê a correspondente informação bibliográfica completa, em nota de rodapé. Aqui reside a maior dificuldade do principiante em Epigrafia e mesmo em História: as citações bibliográficas que encontra são dadas inúmeras vezes em siglas, nomeadamente quando se trata de artigos de revistas. Geralmente, há, no início do artigo ou livro, uma lista de abreviaturas, ou, na primeira nota respeitante a uma obra, a sigla ou palavras que passarão a ser usadas para se não alongar o texto. Contudo, nem sempre tal acontece. Por isso, sugerimos que se consulte para o efeito - no caso da Antiguidade Clássica - a lista de abreviaturas publicada pela revista L'Année Philologique, repositório utilíssimo de todos os trabalhos editados ao longo do ano sobre Antiguidade; essas abreviaturas são hoje utilizadas universalmente.

\subsection{O estudo de uma inscrição inédita}

Exemplifique-se o que atrás fica dito, mediante o estudo publicado de um monumento inédito 5 :

Placa funerária, de mármore cinzento de Trigaches, achada junto ao Tanque dos Arrozes, na Herdade da Fonte dos Frades (freguesia de Baleizão, concelho de Beja), quando se procedia a trabalhos agrícolas ${ }^{6}$.

Está guardada na Horta do Padre, da mesma herdade, onde a observámos e fotografámos ${ }^{7}$.

5 Rafael A. E. ALFENIM e José d'ENCARNAÇÃO in Ficheiro Epigráfico, 56, 1997, n 259.

${ }^{6}$ Existe nessa herdade uma villa romana, de que já foram postos a descoberto: uma sala com ábside, mosaicos e o peristilo da domus senhorial, e as termas. As ruínas, datáveis do século I ao V d. C., estendem-se por mais de 150 metros. Cf. ALARCÃO (Jorge de), Roman Portugal, Warminster, 1988, II, 3, p. 197, no 8/145.

Sita no território de Pax lulia, a villa pertencia, pois, ao conventus Pacensis.

7 Agradecemos à Senhora D. Cremilde Maria Rosado Femandes Doderer, proprietária da herdade, e a seu irmão, o Senhor Professor Doutor Raul Miguel Rosado Fernandes, que nos acompanhou na visita ao local, as facilidades concedidas para a realização deste trabalho. 
Trata-se de um bloco irregularmente paralelepipédico, apenas alisado na face que ostenta a inscrição. Aliás, nem sequer houve o cuidado de fazer as arestas rigorosamente rectilíneas, porque a placa se destinava a ser incrustada no frontispício do monumento funerário, deixando à mostra somente a zona epigrafada.

Dimensões: 18 x 38 x 9/12.

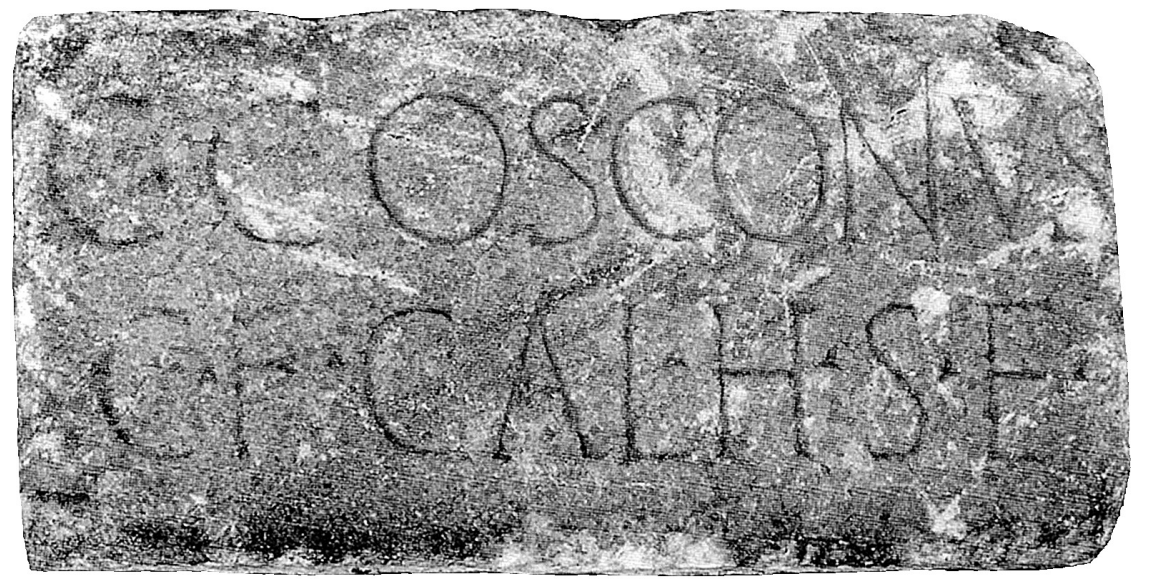

$\mathrm{C}($ aius $) \cdot \mathrm{COSCONIVS} \mathrm{/} \mathrm{C}($ aii $) \cdot \mathrm{F}($ ilius $) \cdot \mathrm{GAL}($ eria tribu $) \cdot \mathrm{H}($ ic $) \cdot \mathrm{S}($ itus $) \cdot \mathrm{E}($ st $)$. Aqui jaz Gaio Coscónio, filho de Gaio, da tribo Galéria.

Altura das letras: 1. 1: 5 (nexo NI =6,7); 1. 2: 5/5,5. Espaços: 1: 3,4/2; 2: 2; 3: 3,5.

Paginação segundo eixo de simetria, em que a pontuação, triangular, exerce também funções estéticas. Recurso ao (habitual) nexo NI como solução de emergência (veja-se o contraste entre o espaço interliteral no princípio e no fim da linha).

Caracteres do tipo monumental quadrado: C e O bem circulares, S simétrico e vertical, G de haste vertical e breve, H largo, barras horizontais. Um certo requinte nos vértices, que ostentam pequenas barras, índice da presença prévia de linhas auxiliares e, no caso do E e do F, de cuidado posto na gravação, feita com goiva. 
Estamos, como dissemos, perante a placa dum monumento funerário familiar em que apenas o primeiro a ser sepultado vem identificado. Os demais familiares ali terão sido enterrados também, mas não se lhes fez memória lapidar.

Pertence o defunto à tribo Galéria, que é a de Pax Iulia. O seu gentilício não é frequente na epigrafia romana peninsular. De facto, a darmos crédito aos índices de ILER (p. 684), somente teríamos quatro testemunhos documentados: n. ${ }^{\text {os }}$ 5660, 5664, 3566 e 5545. Para melhor enquadrarmos, no espaço e no tempo, a personagem memorada na Fonte dos Frades, talvez não seja despiciendo referir, ainda que muito brevemente, o que se sabe de cada um deles.

Foi o primeiro Coscónio testemunhado um soldado da X Legião Gémea falecido em Samora. Inscrito na tribo Galéria, parece ser natural de Arsa ou Arse, porquanto, a seguir à menção da tribo, está grafado ARS, passível de desdobrarse em Arsensis. Segundo Tovar ${ }^{8}$, há possibilidade de terem existido duas cidades com o nome de Arsa: uma na Betúria e outra no conventus Gaditanus. De qualquer modo, o adjectivo Arsensis figura, refere Tovar, na inscrição HAE 2085; aliás, o próprio Tovar alude também a este soldado. Francisco Beltrán prefere a grafia Arse, o nome ibérico da cidade romana de Saguntum, que teria sido elevada à categoria de município entre 56 e 4 a. C. ${ }^{9}$. Parece, portanto, aceite que, no caso vertente, estamos perante a menção da origo e não de um cognomen.

A segunda epígrafe, em bastante mau estado de conservação, identificada no concelho de Sintra, é relativa a um outro soldado, talvez da XV Legião. Não sabemos qual o seu praenomen; recebeu, porém, um cognome tipicamente lusitano, Reburrus (no texto grafado com um só R). ${ }^{10}$

A terceira inscrição assinala, em Écija, o espaço funerário do duúnviro C. Cosconius Taurus e de Sulpicia Anus. Inscrito na tribo Papíria, Tauro é, seguramente, cidadão de Mérida e nessa colónia terá exercido funções.

\footnotetext{
${ }^{8}$ António TOVAR, Iberische Landeskunde (Baetica), Baden-Baden, 1974, 55 e 92.

9 Francisco BELTRÁN LLORIS, Epigrafia Latina de Saguntum y Su Territorium, Valencia, 1980, p. 380-382.

${ }^{10}$ Sobre esta inscrição, poderá ver-se ainda: HAE 1211; Scarlat LAMBRINO, "Les inscriptions de S. Miguel de Odrinhas", Bulletin des Études Portugaises, n. s., XVI, 1952, n. ${ }^{\circ}$ 21, p. 140-141; AE 1954 252; Fernando Bandeira FERREIRA, "Notícia de três inscrições lusitano-romanas de Janas e de S. Miguel de Odrinhas", Brotéria 61 (Nov. 1955) 420; Mário CARDOZO, Catálogo das Inscrições Lapidares do Museu Arqueológico de S. Miguel de Odrinhas, Sintra, 1956, p. 37, n.․ III.
} 
Finalmente, ILER 5545 refere o áugure L. Cosconius, natural de Vallata, uma mansio localizada perto de Astorga ${ }^{11}$.

A estes se hão-de juntar: a mirobrigense Coscónia Materna, de cujo monumento funerário se encontrou menção numa quinta da província de Badajoz (HEp 11989 n. ${ }^{\circ}$ 87); Q. Cosconius Cousanus e uma outra Cosconia memorados no texto, procedente de Ciudad Real, que Géza Alföldy data da primeira metade do século I (cf. HEp 21990 n. ${ }^{\circ}$ 282); o dedicante duma ara votiva do Museu de Segóvia, (...) Cosconius Ovinianus (HEp 31993 333). Recorde-se, a terminar, o antropónimo Cosconius a servir de cognomen na lista onomástica de Faro (IRCP 10).

Julgamos, pois, ter recolhido elementos bastantes para demonstrar a importância da "linhagem" com que Gaio Coscónio esteve relacionado. Não andaremos, certamente, longe da verdade se o considerarmos integrável na primeira leva de colonos itálicos de Pax Iulia.

Na verdade, pela paleografia, pelo modo de gravação, pela simplicidade do texto e pela ausência de cognomen do defunto, é monumento datável dos finais do século I antes da nossa era - o que está de acordo com o que se disse acerca dos outros testemunhos aduzidos.

\subsection{As falsificações e as cópias}

Ao tempo dos humanistas, desejava-se a todo o custo ligar a história pátria às tradições romanas. Cientes da importância da Epigrafia como fonte histórica, não hesitaram os mais diversos autores em forjar textos que servissem para demonstrar a vitalidade da sua região durante o domínio romano. Isso aconteceu entre nós com André de Resende, que procurou fazer de Évora a grande metrópole da Lusitânia, o centro de actividade de Sertório; por isso mandou gravar as mais eruditas inscrições, no estilo da melhor epigrafia ${ }^{12} \ldots$

\footnotetext{
${ }^{11}$ Cf. CIL 112647 e Tomas MAÑ̃́NEZ PÉREZ, Epigrafĩa y Numismática de Astorga y Su Entorno, Salamanca, 1982, p. 126 (nํㅜ 122).

${ }^{12}$ Além do que escrevi em Estudos sobre Epigrafia (p. 29-56), poderá ver-se "André de Resende, epigrafista", Cataldo E André de Resende - Congresso Internacional do Humanismo Português, Lisboa, 2002, p. 305-310.
} 
Exemplifiquemos essa utilização política de uma epígrafe romana forjada:

Cipo pretensamente romano, decerto mandado executar por André de Resende. Está nas reservas do Museu Regional de Évora.

Aquele humanista refere-se ao monumento no livro IV (folhas 220 e 221) do seu De Antiquitatibus Lusitaniae. Afirma que o viu junto à porta da igreja de Beja (onde outrora fora colocado para decoração), entre umas colunas aí jazentes. Acrescenta que a sua fastidiosa leitura o deteve mais de três horas e que tantos eram os maus tratos nele infligidos por gente bárbara que desesperou de perceber integralmente o seu sentido.

A transcrição que dá no livro não obedece à paginação patente no monumento e também não corresponde exactamente ao que aí se vê a leitura apresentada:

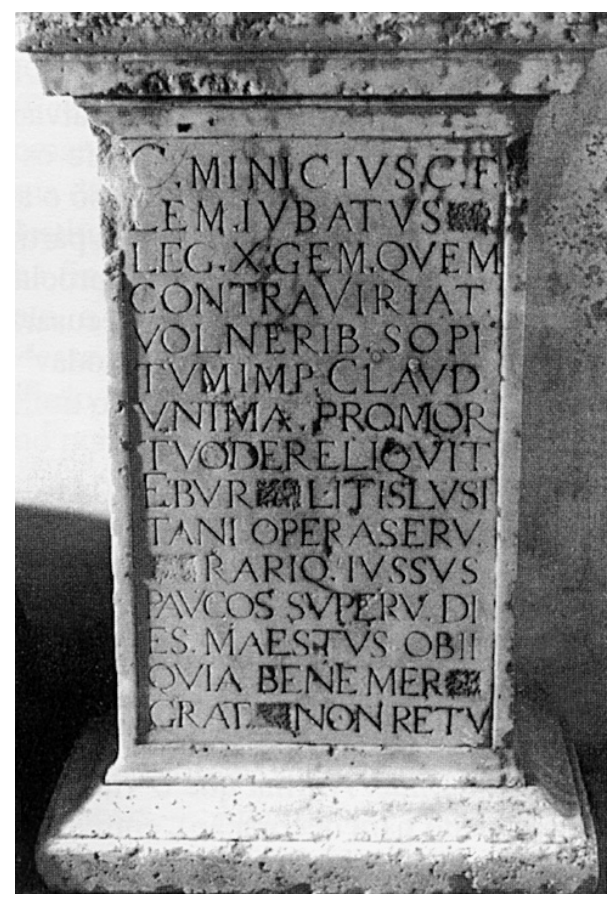

Caius Minicius Cai filius Lemonia iubatus Tribunus legionis decimae geminae quem in proelio contra Viriatum volneribus sopitum imperator Claudius unimanus pro mortuo dereliquit, Ebutii militis Lusitani opera servatus curariq. iussus, paucos superuixi dies, moestus obi quia benemerenti more Romano gratiam non retuli.

Ou seja:

"Gaio Minício, filho de Gaio, da tribo Lemónia, tribuno ornado de crina da 10aㅡ Legião Gémea, a quem, na luta contra Viriato, desmaiado por causa dos ferimentos, o imperator Cláudio "maneta" abandonou como morto. Graças a 
Ebúcio, soldado lusitano, fui poupado e mandado tratar; poucos dias sobrevivi; morri triste por ao benfeitor não ter agradecido segundo o costume romano".

A intenção do texto é evidente: para além de documentar uma importante baixa dos Romanos na luta contra Viriato, pretende exaltar a bondade lusitana mesmo para com um inimigo ignobilmente abandonado pelo seu chefe militar.

O primeiro aspecto a ter em conta será, pois, o seguinte: não se faz uma falsificação sem um objectivo. Recorde-se, a propósito, o que foi o caso das Actas das Cortes de Lamego, fabricadas pelos monges alcobacenses... Por conseguinte, se o texto vem demonstrar algo de muito importante - a localização dum povo, duma cidade, a existência de magistrados relevantes... - há que duvidar.

Para além da análise da pátina do material, proceder-se-á a minuciosa análise interna do texto. Assim,

- o formulário não pode conter contradição nem afastar-se da fraseologia habitual;

- na Península Ibérica, o E e o F devem ter as barras de igual tamanho, o U grava-se sempre V;

- a pontuação é a meio das letras e não em baixo, como actualmente.

Importa, contudo, distinguir uma falsificação duma cópia ${ }^{13}$. Temos, entre nós, diversos exemplos de cópias de inscrições, de cuja autenticidade não nos é lícito duvidar: os textos da igreja de Bobadela, o marco delimitatório do Fundão (de que já se falou), as inscrições do chafariz da Sr ${ }^{\text {a }}$ do Monte em Santiago do Cacém ${ }^{14}$. A cópia visa somente perpetuar um testemunho que vai perder-se ou está em risco disso - e tem, muita vez, a data da "reconstituição".

\footnotetext{
13 Cf. José d'ENCARNAÇÃO, "Autenticidade em Epigrafia - As inscrições de Cuba e Vila Nova de Baronia", Arquivo de Beja 28-32, 1971-75, p. 57-62.

${ }^{14}$ Ver D. Fernando de ALMEIDA, Ruínas de Miróbriga dos Célticos, Setúbal, 1964, p. 49-53.
} 


\section{A VALORIZAÇÃO MUSEOGRÁFICA DAS EPÍGRAFES}

Desenvolveram-se enormemente, nos últimos 25 anos, os estudos epigráficos e a consequente identificação de monumentos um pouco por toda a parte, de tal modo que não há praticamente nenhum museu, mormente se de Arqueologia ou de âmbito local ou regional, que não integre no seu acervo várias "pedras com letras" datadas do tempo dos Romanos ou mesmo da Idade Média ou dos tempos modernos.

São, efectivamente, peculiares as características deste tipo de monumentos, o que implica uma atenção particular à sua técnica expositiva. E há que estarmos sensibilizados para tal.

Na verdade, a primeira ideia a reter é a de que, de um modo geral, esses monumentos andam dispersos: metidos nas igrejas - em pináculos, nas paredes, a servirem de pia de água benta ou de pedestal de um santo; encastradas em paredes; reaproveitadas numa ponte, num peitoril, num portal, a servir de coluna; usadas com novos letreiros; abandonadas por terras e caminhos; guardadas em colecções particulares, em local apropriado ou num pátio ao ar livre. Trata-se, de facto, de um património por cuja recolha e/ou salvaguarda o responsável pelo museu local deve pugnar.

No passado, a recolha em museus fez-se, em regra, atabalhoadamente, uma vez que esse tipo de peças - pesadas, feias, de mensagem sóbria e enigmática... - parecia mais destinado a reservas ou a um pátio interior. E, assim, não será raro vê-las a monte, sem indicação de proveniência, sem registo... - a possibilitar, de resto, ao epigrafista o inesperado achamento de inéditos ou a identificação de peças que há muito julgara perdidas. Um "armazém" foi outra das hipóteses, como acontecia, até há pouco, na chamada 'catedral' de Idanha-a-Velha.

Aqui e além, contudo, criaram-se "galerias lapidares", geralmente a ocuparem pórticos (não raro os museus eram adaptações de antigos edifícios com pátio interior) e jardins. Bem conhecido, por exemplo, o caso do Museu da Sociedade Martins Sarmento, em Guimarães, até há muito pouco tempo. Esse esquema se adoptou no Museu dos Condes de Castro Guimarães, de Cascais, e é bem 
sabido como o pátio interior do Museu Nacional de Arqueologia, antes da actual arrumação, estava pejado de pedras com letras, entre as quais medrava a erva... No Museu do Abade de Baçal, em Bragança, as epígrafes quase que serviam de embelezamento do jardim. E quando se procedeu à reinstalação (se assim se pode dizer) do Museu de Francisco Tavares Proença Júnior, de Castelo Branco, as peças epigrafadas saíram para o pátio e por lá ficaram, na expectativa de uma selecção: que é que vai ser exposto, que é que vai para a reserva... Aliás, nesse domínio, tanto o Museu Distrital de Évora como o Museu Regional Rainha D. Leonor, de Beja, resolveram o problema: puseram no pórtico interior as inscrições mais significativas e o resto foi para a reserva, no primeiro caso, para o pátio, no segundo.

É que, de facto, 'pedregulhos' assim apresentam sérias dificuldades de sistematização. Vamos arrumá-los por temas, como fez D. Fernando de Almeida quando juntou, no primeiro andar do Museu de Belém, tudo o que dizia respeito a Endovélico? Privilegiaremos, ao invés, as áreas geográficas: tudo o que diz respeito à necrópole de Silveirona (Estremoz), tudo o que se prende com Olisipo... Ou - sejamos práticos - usamos apenas a técnica do espaço disponível? No Museu de Elvas, as placas epigrafadas romanas foram encastradas na parede, ainda que isso tivesse levado a partir o revestimento de azulejos; em Beja, todos os cantinhos se aproveitaram e, por isso, até o alpendre junto à entrada, tem peças epigrafadas de grandes dimensões, como o pedestal em honra de Lúcio Márcio Píero ou as cupas mais avantajadas. Em Faro, no então chamado Museu Arqueológico e Lapidar Infante D. Henrique, o lintel do templo ao Imperador ficou assente sobre duas mísulas de pedra porventura nossas contemporâneas. No anterior Museu do Castelo de Vila Viçosa - que precedeu a excelente arrumação nele feita sob orientação da Dra. Jeannette Nolen - fragmentos de epígrafes estavam em prateleiras, algumas colavam, mas nada se ousara fazer.

Depois, há os problemas estéticos. Encontradas, a maior parte das vezes, em reaproveitamento que as desfigurou, as lápides não seduzem pela forma. Daí que se não hesitasse em colar-lhe etiquetas de madeira negra mesmo na face 
dianteira e se escrevesse, em letras gradas, o número de inventário, bem à vista de todos...

E o peso - com a consequente dificuldade de 'manobra' - foi constituindo um óbice maior, pelo menos até se terem inventado os modernos processos de deslocação desses 'pesos' sem os molestar. Não é segredo para ninguém que a remodelação do Museu Nacional de Arqueologia e o consequente armazenamento em prateleiras fortes e em contentores do abundante material epigrafado resultante da pesquisa de Leite de Vasconcelos se não fez sem alguns desaires.

Não há, na actualidade, museu nenhum que não tenha encetado ou não esteja para encetar um processo de remodelação e de nova apresentação das suas colecções de forma didáctica e atraente. E se para as demais peças arqueológicas se requer imaginação e bom gosto, para o que às epígrafes diz respeito, designadamente as epígrafes romanas, é mesmo preciso reflectir maduramente e, nesse aspecto, do parecer do epigrafista dificilmente se poderá prescindir, a não ser que o museólogo detenha já luzes bastantes acerca do real significado das peças em presença.

E, aqui, uma palavra merece atenção maior: objectivo. A exposição - pensada quer em termos de permanente quer como temporária - tem um programa. Nesse programa, que papel está reservado às epígrafes?

Em Conímbriga, por exemplo, um museu monográfico, cujo programa é dar a conhecer o quotidiano das gentes que por ali passaram, as epígrafes vão sendo significativamente espalhadas: aqui, a mostrar que havia oficinas lapidárias; mais além, a exemplificar o tipo de escrita e o respectivo suporte; em seguida, a saudação - V(tere) F(elix), "Felicidades!» - do anel de uma matrona. $\mathrm{Na}$ sala reservada ao fórum, o cipo a homenagear um dos notáveis conimbricenses que nesse fórum, um dia, fez promessas eleitorais... Ao fundo, no recanto destinado ao mundo do Além, os ex-votos, os epitáfios dispostos como que em necrópole, os esconjuros e os mágicos dizeres...

Em Odrinhas, ao invés, temos um «livro de pedra", ou melhor, inúmeros livros de pedra, que era preciso mostrar na sua quantidade, pois isso de modo especial caracterizou as gentes romanas que por ali passaram, há mais de dois 


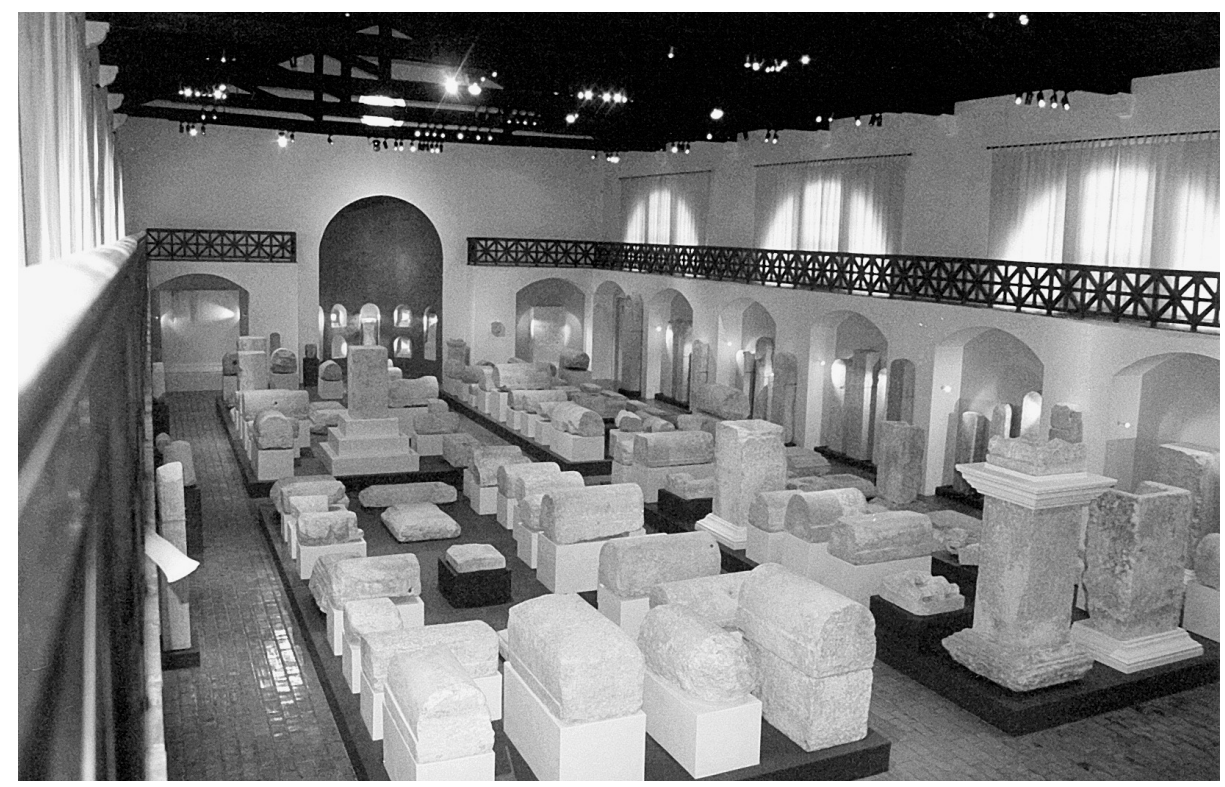

199

mil anos atrás. A pedra abundava, os epitáfios eram de moda, a necessidade de "Salvar o nome do esquecimento" impunha-se às famílias de ricos proprietários que, logo desde os primórdios da chegada dos Romanos, ali lograram prosperar. Portanto, importava mostrar, como numa basílica que parece de ar livre, com seu cardo e seu decumanus, os muitos epitáfios encontrados, registo fiel dessas famílias ilustres. E, na cabeceira, em abside, como em altar-mor, os ex-votos diversos, no ritual sagrado...

Aliás, esse esquema acabou José Cardim Ribeiro por o utilizar na exposição Religiões da Lusitânia - Loquuntur Saxa, exactamente porque, neste domínio da relação entre os homens e os deuses, o que mais nos impressiona, porque foi o que ficou, é esse "falar das pedras"...

Claro que teremos regras a sugerir: a colocação junto às paredes, mas nunca nelas embutidas, para que se possa ver a espessura e analisar a peça também pela sua face posterior (já lá vai o tempo em que apenas o texto interessava numa epígrafe!...). A utilização de peanhas para que a leitura se faça sem esforço, ou melhor, para se dar uma ideia tão aproximada quanto possível do que fora o contexto arqueológico do monumento. A iluminação cuidada, porque, se é mui presumível que, originalmente, essas letras foram pintadas, hoje 
não o estão e é através de uma luz rasante que a leitura melhor se fará. A legenda - como, de resto, para as demais peças - não deverá impor-se mas servir, discretamente, como guia explicativo quanto baste (porque teremos o Guia ou, mais explícito ainda, o Catálogo).

Quebra-cabeças maior é a reserva. Desde logo, porque requer amplidão de espaço; depois, por ter de dar ao estudioso acessibilidade à peça na sua totalidade. A colocação de pequenos fragmentos em prateleiras metálicas afigura-se-nos boa prática, sendo, porém, requerida a maior atenção para, num adequado registo, se saber exactamente onde é que a peça se encontra.

Dir-se-á, à partida, que a maior parte das epígrafes constantes da colecção de um museu, mesmo local ou regional, se destina a ficar em reserva, aguardando o dia em que lhe seja dada a honra de vir a figurar numa exposição temática temporária. Contudo, nada impede que, num museu com um núcleo exíguo de epígrafes, não se opte por tudo expor, devidamente enquadrado e explicado. Pensa-se, amiúde, que um fragmento com três-quatro letras não merece o trabalho da sua exposição. Depende! Também aqui não há receitas mágicas, porquanto tudo se relaciona com o significado que esse fragmento pode ter. Imagine-se que é mármore de Estremoz/Vila Viçosa numa zona em

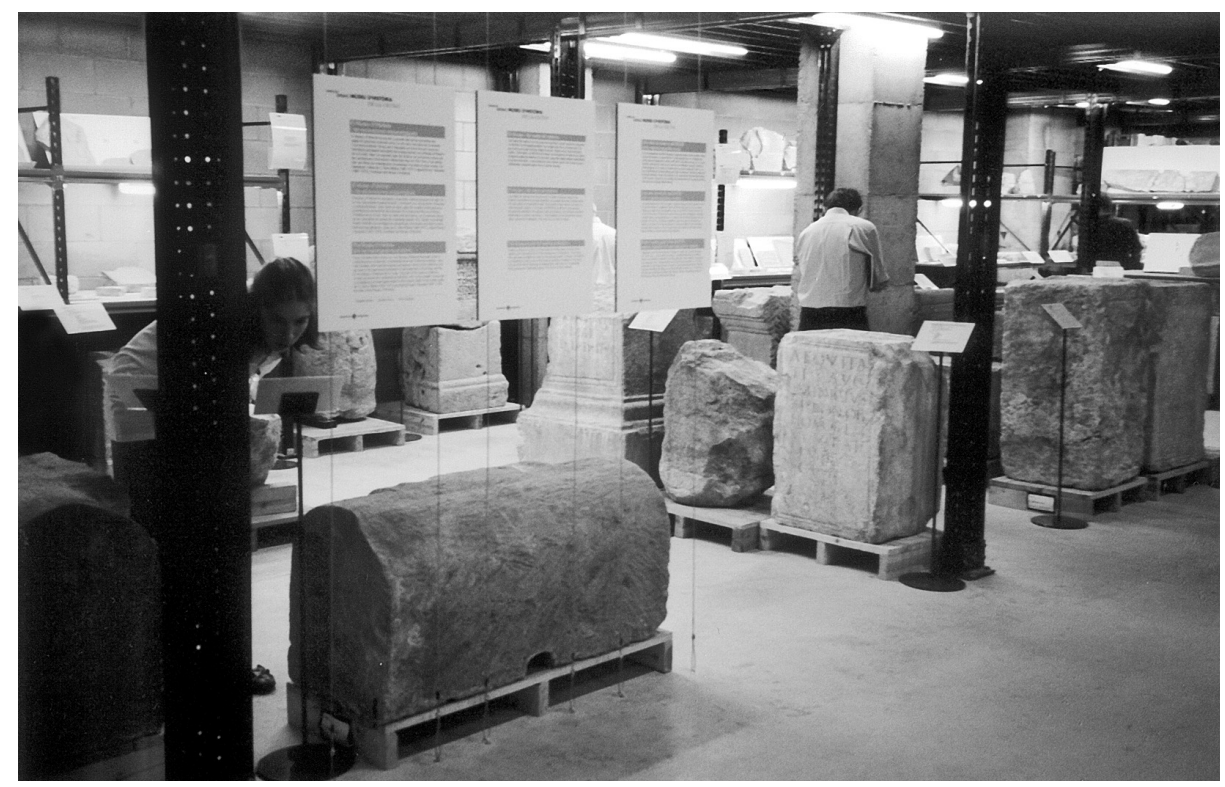


que predomina o granito! Constituirá, nesse caso, ainda que indecifrável ou indecifrada, uma peça a não descurar!

O Museu da História da Cidade de Barcelona poderá ser, nesta problemática, um exemplo a reter. Sito em pleno centro histórico, contendo no seu subsolo as ruínas de Barcino - para onde se desce num elevador que, significativamente, nos faz recuar no tempo... - manteve nessas ruínas, frequentemente no próprio local de achado, as epígrafes identificadas. Mas Barcelona é fecundo manancial; por isso, o Ayuntamiento recorreu a amplos armazéns, na periferia da cidade, para onde trasladou tudo o que era peça epigrafada que não caberia no sempre exíguo espaço de um museu de história e que também não teria cabimento no Museu Arqueológico propriamente dito. E aí, colocados sobre estrados de ágil deslocação, os monumentos podem facilmente ser examinados e fotografados em todas as posições que se deseje.

Merece referência especial o ficheiro. Tem o museólogo a preocupação de o actualizar em relação a todas e a cada uma das peças que constituem o acervo do museu ao seu cuidado. Contudo, há peças e peças. E, sem querer considerar 'excepcionais' as peças epigrafadas, o certo é que, nos últimos tempos, se têm multiplicado estudos e referências e análises às mais diversas epígrafes, porque outras interpretações se deram, outros dados novos surgiram... Um ficheiro epigráfico actualizado é, pois, fundamental, não só para servir de bom guião para uma eventual exposição temporária a fazer futuramente ou para os elementos a divulgar quando a epígrafe for escolhida para "peça do mês" ou "do semestre», mas também para ajudar na elaboração de um bom catálogo ou apoiar eficazmente o investigador que a pretenda re-analisar.

Mais adiante se dá conta do que existe nesse domínio dos catálogos epigráficos dos museus portugueses. O panorama mantém-se sensivelmente idêntico há vários anos, embora se espere que, a muito breve trecho, boa parte dos museus municipais com inscrições romanas e medievais lhes dê a atenção que, como fonte histórica singular, efectivamente merecem. Mas não há que lamentarmo-nos de atrasos: o próprio British Museum tem o seu acervo epigráfico arrumado ainda à maneira antiga, as peças umas ao lado das outras; as etique- 
tas, embora elucidativas, a necessitarem de actualização... No Metropolitan de Nova Iorque, os monumentos expostos são muito bonitos; contudo, nem sempre se diz donde são provenientes (bonni soit qui mal y pense!...). E só muito recentemente, com o apoio da American Academy in Rome se publicou, por iniciativa de John Bodel e Stephen Tracy, uma "checklist" das Greek and Latin Inscriptions in the USA (Roma, 1997), de que Maria das Dores Girão Cruz fez adequada recensão na Conimbriga (38, 1999, 235-238). Quantas colecções particulares e institucionais se poderão dar ao luxo de ter bons catálogos, como aqueles a que o Gabinete de Antigüedades da Real Academia de la Historia, em tão boa hora, lançou mão: Epigrafía Hispánica, da responsabilidade de Juan Manuel Abascal e Helena Gimeno e a colaboração de Isabel Velázquez (Madrid, 2000, 390 páginas, dotadas de utilíssimos índices); e Epigrafía Prerromana, da responsabilidade de Martín Almagro-Gorbea, com a colaboração de Manuel Molina Matos, José Manuel Galán, Luis Alberto Ruiz Cabrero e Concepción Blasco Bosqued (Madrid, 2003, 544 páginas, também elas bem secundadas por índices da maior utilidade)?!

No volume XIV (1985) da revista Conimbriga, apresentei (p. 239-240) breve recensão do primeiro livro que expressamente abordou esta temática: Il Museo Epigrafico. Editado em Faenza (1984), contém, nas suas 640 páginas, as comunicações apresentadas a um colóquio internacional, realizado na EmiliaRomagna, no Outono de 1983, sob a égide da Association Internationale d'Épigraphie Grecque et Latine, ciente da problemática que, nessa primeira parte da década de 80, a valorização museológica das epígrafes estava a despertar. Nessa obra, a única que, até ao momento (que eu saiba), expressamente se debruçou sobre as questões que se prendem com esta temática, se poderão colher, ainda hoje, sábios ensinamentos.

Antonina Maria Cavallaro e Patrizia Framarin escreveram, na revista Epigraphica (L, 1988, 264-272), uma breve mas substancial nota intitulada "Il nuovo museo dell'Ospizio del Gran S. Bernardo. Problemi di riordino e proposta di fruizione di una raccolta antiquaria in un piccolo museo del territorio", bem elucidativa, pois dá particular relevo à apresentação do espólio do impor- 
tante santuário rupestre (Pan de Júpiter) aí existente, junto ao Lacus Poeninus, constituído por inúmeras placas votivas dedicadas a Poeninus, a Iuppiter Poeninus e às Dominae.

Útil será, ainda, a leitura dos comentários feitos por Giancarlo Susini ao Lapidarium Hungaricum ${ }^{15}$, uma interessante iniciativa da Academia das Ciências da República da Hungria. Recorde-se, a propósito, que o último texto escrito por aquele eminente e saudoso epigrafista foi dedicado precisamente ao Museu de Odrinhas, cuja concepção elogiou ${ }^{16}$.

Outro autor que a esta problemática vem dedicando grande atenção é António Sartori, de Milão. Dele recordaria, a propósito, o comentário “"La memoria dei cittadini»: il lapidario urbano" ${ }^{17}$.

Enfim, pela sua especificidade e pelo hermetismo da sua mensagem e do seu significado, o monumento epigráfico arrisca-se, de facto, a ser, mais do que as outras, no museu, uma peça morta. Competirá ao museólogo e ao epigrafista fazerem-no airosamente ressuscitar na sua luzidia roupagem de importante

\section{objecto cultural.}

\footnotetext{
15 In Epigraphica, LI, 1989, 255-256.

${ }^{16}$ Cf. "Em Sintra, entre os "livros" esculpidos pelos nossos avós", Al-madan, 10, Dez 2001, $210-211$.

${ }^{17}$ In Arte Lombarda (Rivista di Storia dell'Arte), 90-91, 1989, 7-14.
} 
(Página deixada propositadamente em branco) 
ELEMENTOS PARA UM MANUAL

DE EPIGRAFIA ROMANA PENINSULAR 
(Página deixada propositadamente em branco) 


\section{ABREVIATURAS}

\section{Prenomes}
A - Aulus
L - Lucius
SER - Servius
AP - Appius
M - Marcus
SEX - Sextus
C - Caius
M - Manius
SP - Spurius
$\mathrm{CN}$ - Cnaeus
$\mathrm{N}$ - Numerius
TIB - Tiberius
D - Decimus
P - Publius
$\mathrm{T}$ - Titus
K - Kaeso
Q - Quintus
V - Vibius

\section{Tribos}

$\begin{array}{lll}\text { AEM - Aemilia } & \text { HOR - Horatia } & \text { ROM - Romilia } \\ \text { ANI - Aniensis } & \text { LEM - Lemonia } & \text { SAB - Sabatina } \\ \text { ARN - Arnensis } & \text { MAEC - Maecia } & \text { SCAP - Scaptia } \\ \text { CAM - Camilia } & \text { MEN - Menenia } & \text { SER - Sergia } \\ \text { CL - Claudia } & \text { OVP - Oufentina } & \text { STEL - Stellatina } \\ \text { CLV - Clustumina } & \text { PAL - Palatina } & \text { SVC - Suburana } \\ \text { COLL - Collina } & \text { PAP - Papiria } & \\ \text { COR - Cornelia } & \text { POL - Pollia } & \text { TER - Terentina } \\ \text { ESQ - Esquilina } & \text { POM - Pomptina } & \text { TRO - Tromentina } \\ \text { FAB - Fabia } & \text { PVB - Publilia } & \text { VEL - Velina } \\ \text { FAL - Falerna } & \text { PVP - Pupinia } & \text { VOL - Voltinia } \\ \text { GAL - Galeria } & \text { QVIR - Quirina } & \text { VOT - Voturia }\end{array}$

(Em itálico as tribos mais frequentes no território português). 


\section{Abreviaturas mais frequentes}

Para um rol mais exaustivo, ver, por exemplo, os manuais de Cagnat ou de 208 Sandys (p. 294-311), os índices do CIL II (p. 1173-9)...

\section{A}

ABN, ABNEP abnepos

A.C aere collato

AED aedilis; - PL plebis

AEL Aelius, -a

AER.MIL aerarii militaris

A.L Augusti (-ae) libertus (-a)

A.L.F. animo libens fecit

NA annorum, -Os, -is

APP Appius

A.S a solo; - F fecerunt

AVG Augustalis, Augustus (-a)

AVR Aurelius

\section{B}

B.M bene merenti

B.R.P.N bono rei publicae natus

B.VIX bene vixit

C

C Caesar; Caius; cives, civitas; clarissimus; colonia; coniux; curator; curavit -verunt, curante -tibus

CAE(S).N Caesar noster

C.F Gaii filius (filia); carissima filia; clarissima femina; coniux fecit

$\mathrm{CH}, \mathrm{CHO}$, CHOR cohors

C.I clarissimus iuvenis

CL clarissimus; claudius

CL.F clarissima femina

C.M.V clarissimae memoriae vir; - F femina; - $\mathrm{P}$ puer

$\mathrm{COH}$ cohors; $\mathrm{COHH}$ cohortes

COL collegium; colonia

COS consul; COSS consulibus
C.R civis(es) Romanus(i), civitas

Romana

C.R.P curator rei publicae

C.V clarissimus vir

CVR curavit, curaverunt, curante, curantibus

\section{$\mathrm{D}$}

D decreto; dat, dedit; deus, dea; dies, die, diebus; domo; donum, donat

D.D decreto decurionum; dedit dedicavit; dis deabus; donum (vel dono) dedit; domus divina

DDNN domini nostri duo

D.D.S.P dedit de sua pecunia

DES designatus

DE S.P de sua pecunia

D.F de figlinis

DIC dicavit; DIC.N.M.Q dicatus numini maiestatique

D(IS).M(AN) dis Manibus; - ET M et memoriae; - $S$ sacrum

D.N.M(AI).E vel M(AI).Q(VE). E(IVS) devotus numini maiestatique eius

D.P.P de pecunia publica

D.P.S de pecunia sua; - P posuit

D.S de suo

D.S.P de sua pecunia

\section{E}

EQ eques; EQ. C.R (cohors) equitata civium Romanorum

E.V egregius vir

EX T(EST) ex testamento 
$F$ faciendum, fecit

F.C.I(D).Q.P faciendum curavit idemque probavit

FEC fecit, fecerunt

FL Flavius

FL(AM) flamen; FLAM.AVG flamen

Augustalis

F.P filius pientissimus; flamen perpetuus

FR frater

F.S.ET.S fecit sibi et suis

G

G Gaius; Genius; (legio) Gemina

GER(M) vel GERMAN Germania, Germanicus

$\mathrm{H}$

H.A.I.R honore accepto impensam remisit

H.E(X).T.F heres ex testamento fecit

H.L.D.M.A huic loco dolus malus abesto

H.M hoc monumentum

H.M.M honesta missione missus

H.N.S heredem non sequetur

H.S hic situs; H.S.T.F.I hic situs testamento fieri iussit; H.S.E hic situs est; - O.T.B.Q ossa tua bene quiescant

H.S.S hic siti sunt

I

IM(P) imperator; IMP.P.Q.R. imperium populusque romanus

IN H.D.D in honorem domus divinae

I.O.M Iuppiter Optimus Maximus

IVS iussu
L.A libens animo

L.D.P loco dato publice, L.D.P.P.D.D

- pecunia publica decreto decurionum

LEG. AVG legatus Augusti; LEG. LEG legatus legionis

LIB libertus

L.M libens merito

M

M menses; miles; millia; municipium

MAT mater

MAX maximus

M.D mater deum; M.D.M mater deum magna

MEN(S) vel MES menses -ibus

M.P millia passuum

M.LIB mulieris libertus

MVN municipium

$\mathrm{N}$

$\mathrm{N}$ nepos, noster

NEP nepos

NOB. CAES nobilissimus Caesar

$\mathrm{O}$

OB H(ON) ob honorem

OF officina

$\mathrm{P}$

P pater; pedes; posuit; provincia

P.C ponendum curavit

P.I.S pius in suos

PONT(IF) pontifex; PONT.MAX maximus

P.P pater patriae; pecunia publica; praefectus praetorio; praeses provinciae; propraetor 
P.P.L praeses provinciae Lusitaniae P. R populus Romanus

PR praefectus; praetor; provincia PROC vel PROCO vel PROCOS vel 210

PROCOSS proconsul

PROC procurator

PRON pronepos

P.R.Q populus Romanus Quiritium

PR.VRB praetor urbanus

P.S pro salute

\section{Q}

Q quaestor

Q.S.S.S qui subscripti (scripti) sunt

$\mathrm{R}$

RES P res publica

R.P res publica

S

S sacrum; servus

SAC sacerdotes, sacrum
SAL salus

S.C senatus consultum

SER Servius; servus

SP Spurius; SP.F Spurii filius

S.V.T.L sit vobis terra levis

\section{$\mathrm{T}$}

T.F.I.H.F.C testamento fieri iussit, heres faciendum curavit

T.P.I testamento poni iussit

TR. M(IL), tribunus militum

TR.POT tribunicia potestate

TRIB tribunus

T.R.P.D.S.T.T.L te rogo praeteriens dicas sit tibi terra levis

V

V.C vir clarissimus

VET veteranus

VIAT viator

VIS visu

VIX vixit

V.S votum solvit 


\section{Dinastia dos Júlios-Cláudios}

Augusto (27 a. C. - 14 d. C.): IMP CAESAR AVG

Tibério (14-37): TI CAES AVG

Caligula (37-41): C CAESAR AVG GERMANICVS

Cláudio (41-54): TI CLAVDIVS CAESAR AVG GERMANICVS

Nero (54-68): NERO CLAVDIVS CAESAR AVGVSTVS GERMANICVS

\section{Dinastia dos Flávios}

Vespasiano (69-79): IMP CAESAR VESPASIANVS AVG

Tito (71-81): IMP TITVS CAESAR VESPASIANVS AVG

Domiciano (81-96): IMP CAESAR DOMITIANVS AVG

\section{Dinastia dos Antoninos}

Nerva (96-98): IMP CAESAR NERVA AVG

Trajano (97-117): IMP CAESAR NERVA TRAIANVS AVGVSTVS

Adriano (117-138): IMP CAESAR TRAIANVS HADRIANVS AVG

Antonino Pio (138-161): IMP CAESAR T AELIVS HADRIANVS ANTONINVS

AVG PIVS

Marco Aurélio (161-180): IMP CAESAR M AVRELIVS ANTONINVS AVG

Lúcio Vero (161-169): IMP CAESAR L AVRELIVS VERVS

Cómodo (176-192): L AELIVS AVRELIVS COMMODVS (no início)

L AVRELIVS COMMODVS (até 180)

M AVRELIVS COMMODVS ANTONINVS AVG (até 190)

L AELIVS AVRELIVS COMMODVS AVG (de $191 \mathrm{em}$ diante)

\section{Dinastia dos Severos}

Septimio Severo (193-211): IMP CAESAR L SEPTIMVS SEVERVS PERTINAX AVG Caracala (198-217): IMP CAESAR M AVRELIVS ANTONINVS AVG às vezes - SEVERVS ANTONINVS AVG 


\section{Imperadores sírios}

Heliogábalo (218-222): IMP CAESAR M AVRELIVS ANTONINVS AVG 212 Severo Alexandre (222-235): IMP CAESAR M AVRELIVS SEVERVS ALEXANDER AVG

Maximino (235-238): IMP CAESAR C IVLIVS VERVS MAXIMINVS AVG Gordiano III (238-244): IMP CAESAR M ANTONINVS GORDIANVS AVG Filipe I (244-249): IMP CAESAR M IVLIVS PHILIPPVS AVG Valeriano (253-259): IMP CAESAR P LICINIVS VALERIANVS AVG Galieno (253-268): IMP CAESAR P LICINIVS VALERIANVS EGNATIVS GALLIENVS AVG

\section{Imperadores ilírios}

Póstumo (258-267): IMP CAESAR M CASSIANVS POSTVMVS LATINIVS Cláudio II (268-270): IMP CAESAR M AVRELIVS VALERIVS ? CLAVDIVS AVG Aureliano (270-275): IMP CAESAR DOMITIVS AVRELIANVS AVG Probo (276-282): IMP CAESAR M AVRELIVS PROBVS AVG

\section{Imperadores da tetrarquia}

Diocleciano (284-305): IMP CAESAR C AVRELIVS VALERIVS DIOCLETIANVS AVG Maximiano (286-305): IMP CAESAR M AVRELIVS VALERIVS MAXIMIANVS AVG Constâncio Cloro (292-306): IMP CAESAR M [ou C] FLAVIVS VALERIVS CONSTANTIVS AVG

Galério (293-311): IMP CAESAR C GALERIVS VALERIVS MAXIMIANVS AVG Maximino Daia (305-313): IMP CAESAR GALERIVS VALERIVS MAXIMINVS AVG Maxêncio (306-312): IMP CAESAR M AVRELIVS VALERIVS MAXENTIVS AVG Licinio (308-324): IMP CAESAR VALERIVS LICINIANVS LICINIVS AVG

\section{Imperadores da casa de Constantino}

Constantino (306-337): IMP CAESAR C [ou L ou M] FLAVIVS VALERIVS CONSTANTINVS AVG Constâncio II (324-362): IMP CAESAR FLAVIVS IVLIVS CONSTANTIVS AVG Juliano (355-363): IMP CAESAR FLAVIVS CLAVDIVS IVLIANVS AVG Valentiniano (364-375): IMP CAESAR FLAVIVS VALENTINIANVS AVG Valente (364-378): IMP CAESAR FLAVIVS VALENS AVG Graciano (367-383): IMP CAESAR FLAVIVS GRATIANVS AVG Teodósio (379-395): IMP CAESAR FLAVIVS THEODOSIVS AVG 


\section{BIBLIOGRAFIA}

\subsection{Manuais}

ANDREU (Javier) [coord.], Fundamentos de Epigrafía Latina, Madrid, 2009.

Disponível em: http://www.liceus.com/cgi-bin/ediciones_portada.asp?op cion $=1$

BATTLE HUGUET (Pedro), Epigrafía Latina, Barcelona, 1946.

BERSANI (Silvia Giorcelli), Epigrafia e Storia di Roma, Roma, 2004.

BLOCH (Raymond), L'Épigraphie Latine. Col. Que sais-je? 534. Paris, s/d.

CAGNAT (René), Cours d'Épigraphie Latine, Paris, ${ }^{4} 1914$.

CALABI LIMENTANI (Ida), Epigrafia Latina. Mailand-Varese, 1963.

CÉBEILLAC-GERVASONI (Mireille), CALDELLI (Maria Letizia) e ZEVI (Fausto), Épigraphie Latine, Saint Just La Pendue, 2006.

CORBIER (Paul), Epigrafía Latina. Universidad de Granada, 2004. Tradução e apêndice de Maurício Pastor Muñoz.

DONATI (Angela), Epigrafia Romana: La Comunicazione nell'Antichità, Bolonha, 2002. [Cf. recensão in Revista Portuguesa de Arqueologia, vol. 7 (n⿳o 1) 2004 672-673].

IGLÉSIAS GIL (José Manuel) y SANTOS YANGUAS (Juan), Vademécum para la Epigrafía y Numismática Latinas, Santander, 2002.

KEPPIE (Lawrence), Understanding Roman Inscriptions, Londres, 1991.

LASSÈRE (Jean-Marie), Manuel d'Épigraphie Romaine. Picard, Paris, 2005.

LÓPEZ BARJA (Pedro), Epigrafía Latina (Las Inscripciones Romanas desde los Orígenes al Siglo III d. C.), Santiago de Compostela, 1993 (cf. recensão in Conimbriga 32-33 1993-1994 421-423).

MANZELLA (Ivan di Stefano), Mestiere di Epigrafista (Guida alla Schedatura del Materiale Epigrafico Lapideo). Roma, 1987.

MARINUCCI (G.), Introduzione all'Epigrafe Latina, Roma, 1989.

REMY (Bernard) e Kayser (F.), Initiation à l'Épigraphie Grecque et Latine, Paris, 1999.

REYNOLDS (Joyce), A Guide for Epigraphers, Paris. 1989.

ROLDÁN HERVÁS (José Manuel), Repertorio de Epigrafía y Numismática Latinas. Salamanca, 1969.

SANDYS (J. E.), Latin Epigraphy. Cambridge, ${ }^{2} 1927$ (reimp. 1969).

SCHMIDT (Manfred Gerhard), Einführung in die Lateinisch Epigraphik, Darmstad, 2004.

SUSINI (Giancarlo), Epigrafia Romana. Roma, 1982 (com muita bibliografia, actualizada e por temas).

THYLANDER (H.), Étude sur l'Épigraphie Latine. Lund, 1952. 


\subsection{Corpora peninsulares}

Indicam-se algumas das obras que recolhem significativo número de textos epigráficos peninsulares.

ABAD (L.) y ABASCAL (Juan Manuel), Textos para la Historia de Alicante. Edad Antigua, Alicante 1991.

ABASCAL (Juan Manuel), "Epigrafía romana de la provincia de Guadalajara", Wad-al-Hayara 101983 49-115.

ABASCAL (Juan Manuel) e GIMENO (Helena), Epigrafía Hispánica, Real Academia de la Historia, Madrid, 2000.

ABASCAL PALAZÓN (Juan Manuel), Inscripciones Romanas de la Provincia de Albacete. Albacete, 1990.

ABASCAL PALAZÓN (Juan Manuel) y RAMALlO ASENSIO (S. F.), La Ciudad de Cartago Nova: la Documentación Epigráfica, Universidad de Murcia, 1997.

ABÁSOlO (José Antonio), Epigrafía Romana de la Región de Lara de los Infantes. Burgos, 1974.

ALFÖLDY (Géza), Die römischen Inschriften von Tarraco (= RIT). Berlim, 1975.

ALMAGRO BASCH (Martín), Las Inscripciones Ampuritanas Griegas, Ibéricas y Latinas. Barcelona, 1952.

ALMAGRO BASCH (Martín), Segobriga II. Inscripciones Ibéricas, Latinas Paganas y Latinas Cristianas. Madrid, 1984.

ALMEIDA (Fernando de), Egitânia. Lisboa, 1956.

ALONSO ÁVILA (Ángeles) e CRESPO ORTIZ DE ZÁRATE (Santos), Corpus de Inscripciones Romanas de la Provincia de Salamanca (Fuentes Epigráficas para la Historia Social de Hispania Romana), Valladolid, 1999.

ALONSO ÁVILA (Ángeles) e CRESPO ORTIZ DE ZÁRATE (Santos), Corpus de Inscripciones Romanas de la Provincia de Zamora (Fuentes Epigráficas para la Historia Social de Hispania Romana), Valladolid, 2000.

ARASA I GIL (Ferrán), La Romanización del Alto Palancia según la Epigrafía, Segorbe, 1992 (María de Luna, V).

ARIAS VILAS (Felipe), LE ROUX (Patrick) et TRANOY (Alain), Inscriptions Romaines de la Province de Lugo (=IRPL). Paris, 1979.

BAÑOS RODRÍGUEZ (Gemma), Corpus de Inscripcións Romanas de Galicia. II - Provincia de Pontevedra, Santiago de Compostela, 1994.

BELLINO (Albano), Inscripções Romanas de Braga (Inéditas). Braga, 1895.

BELTRÁN LLORIS (Francisco), Epigrafía Latina de Saguntum y Su Territorium. Valencia, 1980.

BERNARDES (João Pedro), A Ocupação Romana de Leiria, Faro, 2007.

BONNEVILLE (Jean-Nöel), DARDAINE (Sylvie) e LE ROUX (Patrick), Belo VL'Épigraphie - Les Inscriptions Romaines de Baelo Claudia. Madrid, 1988.

BRANDÃO (Domingos de Pinho), "Epigrafia romana coliponense". Conimbriga 111972 41-192.

CANTO (Alicia Maa), Epigrafía Romana de Itálica (=ERIt), Madrid (1983), 1985. 
CANTO (Alicia Maa), Epigrafía Romana de la Beturia Céltica, Madrid, 1997.

CASTELLÓ (Jaime Juan), Epigrafía Romana de Ebusus, Ibiza, 1988.

CASTILlO (Carmen), GÓMEZ-PANTOJA (Joaquín), MAULEÓN (María Dolores), Inscripciones Romanas del Museo de Navarra. Pamplona, 1981.

CEBALlOS HORNERO (Alberto), Los Espectáculos en la Hispania Romana: La

Documentación Epigráfica, tomos I e II (Cuadernos Emeritenses - 26), Mérida, 2004.

CEBRIÁn (Rosário), Titulum Fecit. La Producción Epigráfica Romana en las Tierras Valencianas, Madrid, 2000.

COLLANTES DE TERÁN (E.) e FERNÁNDEZ-CHICARRO (C.), "Epigrafía de Munigua (Mulva, Sevilla)", Archivo Español de Arqueología 45-47 1972-1974 337-395.

CORELL (Josep), Las Inscripciones Romanas de La Safor. Madrid, 1993.

CORELL (Josep), Inscripcions Romanes de Saetabis i el Seu Territori. Valência, 1994.

CORELL (Josep), Inscripcions Romanes d'Edeta i el Seu Territori. Valência, 1996.

CORELL (Josep), Inscripcions Romanes de Valentia i el Seu Territori. Valência, 1997.

CORELL (Josep), Inscripcions Romanes d'Ilici, Lucentum, Allon, Dianium i els Seus Territoris. Valência, 1999.

CORELL (Josep), Inscripcions Romanes del País Valencià. IA e IB - Saguntum i el Seu Territori. Universitat de València, 2002.

CORELL (Josep), Inscripciones Romanes del País Valencià II: 1. L'Alt Palància, Edeba, Lesera i els seus territoris. II: 2. Els mil-liaris del País Valencia (Fonts històriques valencianes 18), Universitat de València, 2005.

CRESPO ORTIZ DE ZARATE (Santos) e ALONSO AVILA (Angeles), Corpus de Inscripciones Romanas de la Provincia de Burgos, Valladolid, 2000.

CRESPO ORTIZ DE ZARATE (Santos) e ALONSO AVILA (Angeles), Auctarium a los Corpora de Epigrafía Romana del Territorio de Castilla y León. Novedades y Revisiones, Zaragoza, 2000.

DESSAU (Hermann), Inscriptiones Latinae Selectae (= ILS). Dublin/Zurique, 1974 (reed.).

DIAS (Maria Manuela Alves) e GASPAR (Catarina Isabel Sousa), Catálogo das Inscrições Paleocristãs do Território Português, Centro de Estudos Clássicos, Lisboa, 2006.

DÍAZ ARIÑO (Borja), Epigrafia Latina Republicana de Hispania, Barcelona, 2008.

DIEGO SANTOS (Francisco), Epigrafía Romana de Asturias. Oviedo, ${ }^{1} 1959$, 21985.

DIEGO SANTOS (Francisco), Inscripciones Romanas de la Provincia de León. León, 1986.

EDMONDSON (Jonathan), Granite Funerary Stelae from Augusta Emerita, Mérida, 2007.

ELORZA (Juan Carlos), Ensayo Topográfico de Epigrafía Romana Alavesa. Vitoria, 1967. 
ELORZA (Juan Carlos), ALBERTOS ( $\mathrm{M}^{\mathrm{a}}$ Lourdes), GONZÁlEZ (Antonino), Inscripciones Romanas en la Rioja (=IRR). Logroño, 1980.

ENCARNAÇÃO (José d'), Inscrições Romanas do Conventus Pacensis (=IRCP). Coimbra, 1984.

ENCARNAÇÃO (José d'), Roteiro Epigráfico Romano de Cascais. Cascais, ${ }^{1} 1994$, 2001.

ESPINOSA RUIZ (D.), Epigrafía Romana de la Rioja. Logroño, 1986.

ESPLUGA CORBALAN (F. X.) y MAYER i OLIVÉ (Marc) y MIRÓ VINAIXA (M ), "Epigrafía de Begastri", in GONZÁlEZ BLANCO (Antonino) (ed.), Begastri. Imagen y Problemas de Su Historia, Múrcia, 1988, 45-87.

ESTEBAN ORTEGA (Julio), Corpus de Inscripciones Latinas de Cáceres. I. Norba, Universidad de Extremadura, Cáceres, 2007.

ESTEBAN ORTEGA (Julio) e SALAS MARTÍN (José), Epigrafía Romana y Cristiana del Museo de Cáceres, Junta de Extremadura, Cáceres, 2003.

ÉTIENNE (Robert), FABRE (Georges) et LÉVÊQUE (Pierre et Monique), Fouilles de Conimbriga, II - Épigraphie et Sculpture. Paris, 1976.

FABRE (Georges), MAYER (Marc) et RODÀ (Isabel), Inscripcions Romanes de Mataró i la Seva Area (Epigrafia Romana del Maresme). Mataró, 1983.

FABRE (Georges), MAYER (Marc) et RODÀ (Isabel), Inscriptions Romaines de Catalogne (= IRC): I. Barcelone (sauf Barcino), Paris, 1985; II. Lérida, Paris, 1985; III. Gerone, Paris, 1991; IV. Barcino, Paris, 1997; V. Suppléments aux Volumes I-IV et Instrumentum Inscriptum, Paris, 2002.

FATÀS (Guillermo) e MARTÍN-BUENO (Manuel), Epigrafía Romana de Zaragoza y Su Provincia. Saragoça, 1977.

FERNÁNDEZ ALLER (Carmen), Epigrafia y Numismática Romanas en el Museo Arqueológico de León, León, 1978.

FERREIRA (Ana P. R.), Epigrafia Funerária Romana da Beira Interior: Inovação ou Continuidade?, Instituto Português de Arqueologia, Lisboa, 2004.

GARCÍA IGLESIAS (Luis), Epigrafía Romana de Augusta Emerita (tese de doutoramento dactilografada). Madrid, 1972.

GÓMEZ PALLARÈS (Joan), Edición y Comentario de las Inscripciones sobre Mosaico de Hispania. Inscripciones no Cristianas. Roma, 1997.

GONZÁlEZ ROMÁN (Cristóbal) e MANGAS MANJARRÉS (Julio), Corpus de Inscripciones Latinas de Andalucía: III - Jaén, Sevilha, 1991.

GONZÁLEZ (Julián), Inscripciones Romanas de la Provincia de Cádiz. Cádiz, 1982.

GONZÁLEZ (Julián), Corpus de Inscripciones Latinas de Andalucía: I - Huelva, Sevilha, 1989; II - Sevilla, Sevilha, 1991 (tomos 1 e 2), 1996 (tomos 3 e 4).

HANDLEY (Mark A.), Death, society and culture. Inscriptions and epitaphs in Gaul and Spain, A.D. 300-750 (BAR International Series 1135), Oxford, 2003.

HERNÁNDEZ GUERRA (Liborio), Inscripciones Romanas en la Provincia de Palencia. Universidad de Valladolid, 1994.

HERNÁNDEZ GUERRA (Liborio), Epigrafía de Época Romana de la Provincia de Salamanca, Universidad de Valladolid, 2001. 
HERNÁNDEZ GUERRA (Liborio) y JIMÉNEZ DE FURUNDARENA (A.). El Conjunto Epigráfico de Época Romana de Hinojosa de Duero, Salamanca, Salamanca, 2004.

HERNANDO SOBRINO (María do Rosário), Epigrafía Romana de Ávila [ERAv], Bordeaux-Madrid, 2005.

HÜBNER (Emílio), Corpus Inscriptionum Latinarum - II (= CIL II). Berlim, 1869. Suplemento, 1892. Aditamentos in Ephemeris Epigraphica (= EE) 81899 351528 e 91913 12-185. Vide os novos fascículos (editio altera), resultantes da profunda revisão a que se está a proceder: publicaram-se, em 1995, o I dedicado à parte meridional do conventus Tarraconensis (CIL II ${ }^{2} / 14$ ), da responsabilidade de Géza Alföldy et alii (Berlim, 1995), e o relativo ao conventus Cordubensis (CIL II ${ }^{2} / 7$ ), organizado por Armin U. Stylow; em 1998, da responsabilidade de Armin U. Stylow et alii, CIL II $2 / 5$, referente ao conventus Astigitanus.

HÜBNER (Emílio), Inscriptiones Hispaniae Christianae, Berlim, 1871.

HURTADO DE SAN ANTONIO (Ricardo), Corpus Provincial de Inscripciones Latinas (Cáceres) (=CPILC). Cáceres, 1977.

IGLÉSIAS GIL (José Manuel), Epigrafía Cántabra. Santander, 1976.

IGLÉSIAS GIL (José Manuel) y RUIZ (Alicia), Epigrafía Romana de Cantábria. Bordéus - Santander, 1998.

IRG = Inscripciones Romanas de Galicia. Santiago. 1 - Santiago de Compostela , ed. Fermín Bouza Brey e Álvaro d'Ors, 1949 (suplemento, sobre A Corunha, in Cuadernos de Estudios Gallegos 141959 145-164); 2 - Provincia de Lugo, ed. Francisco Vázquez Saco e Manuel Vázquez Seijas, 1954 (substituído por ARIAS VILAS e alii, atrás citado); 3 - Museo de Pontevedra, ed. José Filgueira Valverde e Álvaro d'Ors, 1955 (suplemento, sobre Vigo, in Cuadernos de Estudios Gallegos 161961 5-42); 4 - Provincia de Orense, ed. Joaquín Lorenzo Fernández, Álvaro d'Ors e Fermín Bouza Brey, 1968.

JIMENO (Alfredo), Epigrafía Romana de la Provincia de Soria, Soria, 1980.

JUAN CASTELLÓ (J.), Epigrafía Romana de Ebusus. Ibiza, 1988.

KNAPP (Robert C.), Latin Inscriptions from Central Spain. (Classical Studies 34), Berkeley - Los Ángeles, 1992.

LARA PEINADO (Federico), Epigrafia Romana de Lerida. Lerida, 1973.

LÁZARO PÉREZ (Rafael), Inscripciones Romanas de Almería. Almería, 1980.

LÓPEZ DE LA ORDEN (Mํㅗㅁ Dolores), De Epigraphia Gaditana, Cádis, 2001.

LÓPEZ DE LA ORDEN (Mํㅡㄹ Dolores) y RUIZ CASTELLANOS (A.), Nuevas Inscripciones Latinas del Museo de Cádiz, Universidad de Cádiz, 1995.

LOSTAL PROS (Joaquín), Los miliarios de la Provincia Tarraconense (Conventos Tarraconense, Cesaraugustano, Cluniense y Cartaginense), Saragoça, 1992.

MAÑANES PÉREZ (Tomás), Epigrafía y Numismática de Astorga Romana y Su Entorno. Salamanca, 1982.

MAÑANES PÉREZ (Tomás), Inscripciones latinas de Astorga. Universidad de Valladolid, 2000. 
MAÑANES (Tomás) e SOLANA SAINZ (José Mำ), Inscripciones de Época Romana de la Provincia de Valladolid. Universidad de Valladolid, 1999.

MARINER BIGORRA (Sebastián), Inscripciones Romanas de Barcelona (Lapidarias e Musivas). Parte I: Texto (=IRB). Barcelona, 1973.

MAULEÓN (María Dolores), Indices de las Inscripciones Latinas Publicadas en el Boletín de la Real Academia de la Historia (1877-1950). Pamplona, 1983.

MORÁN (C.), Epigrafía Salmantina. Salamanca, 1922.

NAVARRO CABALLERO (Milagros), La Epigrafía Romana de Teruel. Teruel, 1994.

PALOL (Pedro de) y VILELlA (José), Clunia II. La Epigrafía de Clunia. Madrid, 1987.

PASTOR MUÑOZ (Mauricio), Corpus de Inscripciones Latinas de Andalucía. IV: Granada. Sevilla, 2002.

PASTOR (Mauricio) e MENDOZA (Ángela), Inscripciones Latinas de la Provincia de Granada. Granada, 1987.

PEREIRA MENAUT (Gerardo), Inscripciones Romanas de Valentia (=IRV). Valência, 1979.

PEREIRA MENAUT (Gerardo), Corpus de Inscripcións Romanas de Galicia. I Provincia de A Coruña. Santiago de Compostela, 1991.

PIERNAVIEJA (Pablo), Corpus de Inscripciones Deportivas de la España Romana. Madrid, 1977.

RABANAL ALONSO (Manuel Abilio), Fuentes Literarias y Epigráficas de León en la Antigüedad. I-II, León, 1982.

RABANAL ALONSO (Manuel Abilio) y ABASCAL PALAZÓN (Juan Manuel), "Inscripciones romanas de la provincia de Alicante", Lucentum 41985 191-244.

RABANAL ALONSO (Manuel A.) e GARCÍA MARTÍNEZ (Sonia Maa), Epigrafía Romana de la Provincia de León: Revisión y Actualización, Universidad de León, 2001.

RAMÍREZ SÁDABA (José Luis), Catálogo de las Inscripciones Imperiales de Augusta Emerita. (Cuadernos Emeritenses - 21). Mérida, 2003.

REDENTOR (Armando), Epigrafia Romana da Região de Bragança, Lisboa, 2002.

REYES HERNANDO (Olivia Virginia), El Conjunto Epigráfico de Belorado (Burgos), Universidad de Valladolid, Valladolid, 2000.

RIPOLLÉS (Pedro Pablo), "Sinopsis de epigrafía latina castellonense", Cuadernos de Prehistoria y Arqueología Castellonenses 31976 228-276.

RODRÍGUEZ ALMEIDA (E.), Ávila Romana. Notas para la Arqueología, la Topografía y Epigrafía Romanas de la Ciudad y Su Territorio, Ávila, ${ }^{2} 2003$.

RODRÍGUEZ COLMENERO (Antonio), "Cuenca romana. Contribución al estudio epigráfico I", Lucentum 11982 203-253.

RODRİGIEZ COLMENERO (Antonio), Corpus-Catalogo de Inscripciones Rupestres de Época Romana del Cuadrante Noroeste de la Península Ibérica, A Coruña, 1993.

RODRÍGUEZ COLMENERO (Antonio) (coord.), Lucus Augusti. I. El Amanecer de una Ciudad, A Coruña, 1996. 
RODRÍGUEZ COLMENERO (Antonio), Aquae Flaviae. I: Fontes Epigráficas, Chaves, ${ }^{1} 1987$ (Apêndice fotográfico: Chaves, 1988), ${ }^{2} 1997$ [com novo subtítulo: I. Fontes epigráficas da Gallaecia meridional interior; II. O tecido urbanístico da cidade romana].

RODRÍGUEZ COLMENERO (Antonio), FERRER SIERRA (Santiago) e ÁLVAREZ ASOREY (Rubén D.), Miliarios e Outras Inscricións Viárias Romanas do Noroeste Hispánico (Conventos Bracarense, Lucense e Asturicense), Santiago de Compostela, 2004.

RODRÍgueZ GONZÁlEZ (Antonio), Paseo Epigráfico por el Casco Antiguo de Cáceres, Junta de Extremadura, Cáceres, 2007.

RUBIO FUENTES (Mํa José), Catálogo Epigráfico de Alcalá de Henares, Alcalá de Henares, 1994.

RUIZ TRAPERO (María), Inscripciones Latinas de la Comunidad Autónoma de Madrid (Siglos I-VIII), Madrid, 2001.

SAGREDO SAN EUSTAQUIO (Luis) e CRESPO ORTIZ DE ZÁRATE (Santos), Epigrafía Romana de la Provincia de Palencia. Palência, 1978.

SALAS MARTÍN (José) et al., Inscripciones romanas y cristianas del Museo Arqueológico Provincial de Badajoz, Badajoz, 1997.

SÁNCHEZ ALBALÁ (José Ignacio) e VINAGRE NEVADO (Diego), Corpus de Inscripciones Latinas de Coria. Coria, 1998.

SANTOS YANGUAS (Juan), Ángel Luis HOCES DE LA GUARDIA BERMEJO e DEL HOYO (Javier), Epigrafía Romana de Segovia y Su Provincia (ERSg), Deputación Provincial de Segóvia, 2005.

SERRANO RAMOS (Encarnación) e ATENCIA PÁEZ (Rafael), Inscripciones Latinas del Museo de Málaga. Madrid, 1981.

SILVA (Armando Coelho Ferreira da), A Cultura Castreja no Noroeste de Portugal, Paços de Ferreira, 2007.

SILVA (Augusto Vieira da), Epigrafia de Olísipo. Lisboa, 1944.

STYLOW (Armin U.), "Beiträge zur lateinischen Epigraphik im Norden der Provinz Córdoba", Madrider Mitteilungen 28, 1987, 57-126.

VAZ (João L. Inês), A Civitas de Viseu - Espaço e Sociedade, Coimbra, 1997 (2 volumes).

VENY (Cristóbal), Corpus de las Inscripciones Baleáricas hasta la Dominación Árabe. Roma, 1965.

VIVES (José), Inscripciones Latinas de la España Romana (= ILER). Barcelona, 1971 e 1972 (indices).

ZUCCA (Raimondo), Insulae Baliares. Le Isole Baleari sotto il Dominio Romano, Roma, 1998.

\subsection{Revistas}

L'Année Épigraphique (=AE), Paris (até 1966 integrado na Revue Archéologique). Epigraphica (Rivista italiana di epigrafia), Faenza. 
Ficheiro Epigráfico (= FE), Coimbra. (Suplemento de Conimbriga para as inscrições inéditas, desde 1982). Foi editado em 2003 um CD-ROM dos volumes 1 a 66 (2001).

Hispania Antiqua Epigraphica (= HAE), Madrid.

Hispania Epigraphica (= HEp), Madrid. [1 - 1989 / 11 - 2001, editado em 2005, 1989 / 14 - 2005, editado em 2008]]. Vide www.ucm.es/info/archiepi

Palaeobispanica (Revista sobre Lenguas y Culturas de la Hispania Antigua), Saragoça.

\subsection{Catálogos epigráficos dos museus portugueses}

Alcácer do Sal- cf. IRCP, 852.

Alenquer - DIAS (Maria Manuela Alves) [coord.], Epigrafia Latina do Museu Municipal Hipólito Cabaço (Alenquer), FLL, Lisboa, 2001.

Almodôvar-GUERRA (Amílcar), MESA - Museu da Escrita do Sudoeste. Câmara Municipal de Almodôvar, 2007.

Beja - cf. IRCP, 852.

Braga - Do Museu D. Diogo de Sousa: Isabel SILVA (coord.), D. Diogo de Sousa, Museu Regional de Arqueologia, Roteiro, Instituto Português de Museus, Lisboa, 2005. Do Museu Pio XII: SANTOS (Luciano dos), LE ROUX (Patrick) e TRANOY (Alain), "Inscrições romanas do Museu Pio XII em Braga", Bracara Augusta 371983 183-205. Da cidade: Tranoy (Alain) e LE ROUX (Patrick), "As necrópoles de Bracara Augusta. B. Les inscriptions funéraires", Cadernos de Arqueologia 6-7 1989-1990 187-230.

Bragança - ALVES (Francisco Manuel), Guia Epigráfico do Museu Abade de Baçal. Bragança, 1976. REDENTOR (Armando), Epigrafia Romana da Região de Bragança, Lisboa, 2002.

Cascais - ENCARNAÇÃO (José d'), Roteiro Epigráfico Romano de Cascais, Cascais, ${ }^{1} 1994,{ }^{2} 2001$.

Castelo Branco - FERREIRA (Ana Margarida) [coord.], Arqueologia: Colecções de Francisco Tavares Proença Júnior. Instituto Português de Museus, Castelo Branco. 2004. GARCIA (José Manuel), Epigrafia Lusitano-Romana do Museu Tavares Proença Júnior. Castelo Branco, 1984. (Cf. recensão, de Vasco Gil Mantas, in Conimbriga 241985 224-229).

Chaves - CARDOZO (Mário), Algumas Inscrições Lusitano-Romanas da Região de Chaves. Chaves, 1943. CORTEZ (Fernando Russell), "Lápides romanas do Museu de Chaves", Viriatis 11957 99-113. RODRÍGUEZ COLMENERO (A.), Aquae Flaviae. I: Fontes epigráficas, Chaves, ${ }^{1} 1987$ (Apêndice fotográfico: Chaves, 1988), ${ }^{2} 1997$ [com novo subtítulo: I. Fontes epigráficas da Gallaecia meridional interior; II. O tecido urbanístico da cidade romana].

Coimbra - Cf. ENCARNAÇÃO (José d'), "Notas sobre a epigrafia romana de Coimbra", Actas das I Jornadas do Grupo de Arqueologia e Arte do Centro, Coimbra, 1979 171-180 (com mais bibliografia). 
Conímbriga - Colecções do Museu Monográfico de Conimbriga - Catálogo.

Conímbriga, 1984. Vide acima ÉTIENNE et alii (1976).

Elvas - cf. IRCP, 852.

Evora - cf. IRCP, 853.

Faro - cf. IRCP, 853. PAULO (Dália) [coord.], Caminhos do Algarve Romano,

Câmara Municipal de Faro (Museu Municipal), 2005.

Figueira da Foz - Cf. ENCARNAÇÃO (José d'), "Monumentos epigráficos roma-

nos do Museu Municipal Dr. Santos Rocha (Figueira da Foz)", Conimbriga 32-33 1993-1994 295-302.

Fundão - VAZ (João L.), "Inscrições romanas do museu do Fundão", Conimbriga 16 1977, 5-32 e 1978 60-61 (adenda). ROSA (João Mendes) [coord.], Museu Arqueológico Municipal José Monteiro - Catálogo, Fundão, 2007.

Guarda - JALHAY (Emílio), "Inscrições romanas do museu da Guarda”, Brotéria 501950 560-572.

Guimarães - CARDOZO (Mário), Catálogo do Museu de Martins Sarmento (Secção de Epigrafia Latina e de Escultura Antiga), Guimarães, ${ }^{2} 1972$.

Idanha- $a$-Velha - vide supra ALMEIDA (Fernando de). LAMBRINO (Scarlat), "Les inscriptions latines inédites du Musée Leite de Vasconcelos", O Arqueólogo Português n. s. 31956 5-73. SÁ (Ana Marques de), Civitas Igaeditanorum: Os Deuses e os Homens, Idanha-a-Nova, 2007.

Lagos - cf. IRCP, 853. ARRUDA (Ana Margarida) [coord.], Laccobriga - A Ocupação Romana na Baía de Lagos, Câmara Municipal de Lagos, 2007.

Leiria - BERNARDES (João Pedro), A Ocupação Romana de Leiria, Faro, 2007.

Do Museu da Diocese: FERREIRA (Américo), Alma e Imagem (Museu da Diocese de Leiria-Fátima), Leiria, 2006.

Lisboa - Museu Nacional de Arqueologia: LAMBRINO (Scarlat), "Inscriptions latines du Musée Dr. Leite de Vasconcelos", O Arqueólogo Português n. s. 11951 37-61. Textos do Sul de Portugal: cf. IRCP, 853. Museu do Carmo: ARNAUD (José Morais) e FERNANDES (Carla Varela), Construindo a Memória (As Colecções do Museu Arqueológico do Carmo), Lisboa, 2005 - com textos sobre a epigrafia das diversas épocas ali existente.

Marvão - cf. IRCP, 853. As epígrafes estão no Centro Interpretativo de Ammaia, de que não há ainda o catálogo.

Moura - ENCARNAÇÃO (José d'), "Epigrafia romana do Museu Municipal de Moura", Moura na Época Romana, Moura, 1990, 65-74.

Olhão - Museu de Moncarapacho: cf. IRCP, 854.

Sabugal-Museu do Sabugal. Colecção Arqueológica, Sabugal, 2008.

Santiago do Cacém - cf. IRCP, 854.

Santo Tirso - MOREIRA (A. B.), "Epigrafia romana no concelho de Santo Tirso", Santo Tirso Arqueológico 21992 15-33.

Serpa - ENCARNAÇÃO (José d'), "Epigrafia" in Arqueologia do Concelho de

Serpa, de Maria da Conceição Lopes, Pedro C. Carvalho e Sofia M. Gomes, Câmara Municipal de Serpa, 1998, 105-123.

Sintra - Museu de S. Miguel d'Odrinhas: LAMBRINO (Scarlat), "Les inscriptions 
de São Miguel de Odrinhas", Bulletin des Études Portugaises... 161952 134176; CARDOZO (Mário), Catálogo das Inscrições Lapidares do Museu Arqueológico de S. Miguel de Odrinhas, Sintra, 1956; FONTES (Joaquim), Museu Arqueológico de S. Miguel de Odrinhas, Sintra, ${ }^{3} 1975$. [Novo catálogo em preparação por José Cardim Ribeiro].

Torres Vedras - MANTAS (Vasco Gil), "Inscrições romanas do Museu Municipal de Torres Vedras", Conimbriga 211982 5-99.

Vila Flor - BRANDÃO (Domingos de Pinho), "Estelas funerárias luso-romanas com inscrições latinas no Museu Municipal de Vila Flor", Humanitas 11-12 1959-1960 37-44.

Vila Viçosa - cf. IRCP, 854.

\subsection{Obras sobre antroponímia}

ABASCAL PALAZÓN (Juan Manuel), Los Nombres Personales en las Inscripciones Latinas de Hispania. Múrcia, 1994.

ALBERTOS (María Lourdes), La Onomastica Personal Primitiva de Hispania (=O. Hisp.). Salamanca, 1966.

ALBERTOS (María Lourdes), "Onomastique personnelle indigène de la Péninsule lbérique sous la domination romaine", Aufstieg und Niedergang der Römischen Welt 229.21983 853-892 (com bibliografia exaustiva).

BELTRÁN (Francisco), DE HOZ (Javier) e UNTERMANN (Jürgen), El Tercero Bronce de Botorrita (Contrebia Belaisca), Saragoça, 1996.

KAJANTO (Iiro), The Latin Cognomina, Roma, 1982 (reimp.).

L'ONOMASTIQUE LATINE. Actes du Colloque International sur l'Onomastique Latine organisé à Paris du 13 au 15 Octobre 1975. CNRS, Paris, 1977.

NAVARRO CABALlERO, M. e RAMÍREZ SÁDABA, J. L. [coord.], Atlas Antroponimico de la Lusitania Romana, Mérida-Bordéus 2003.

PALOMAR LAPESA (Manuel), La Onomástica Personal Pre-latina de la Antigua Lusitania (= O. Hisp.). Salamanca, 1957.

SCHULZE (Wilhelm), Zur Geschichte Lateinischer Eigennamen. Berlim, 1966.

SOLIN (Heikki), Beiträge zur Kenntnis der griechischen Personennamen in Rom. Helsínquia, 1971.

SOLIN (Heikki), Die griechischen Personennamen in Rom. Ein Namenbuch, 1, Berlin-Nova Iorque, 1982 (3 vo1.).

SOLIN (Heikki) e SALOMIES (O.), Repertorium Nominum Gentilium et Cognominum Latinorum. Hildesheim, 1988.

UNTERMANN (Jürgen), Elementos de un Atlas Antroponímico de la Hispania Antigua. Madrid, 1965.

VALLEJO RUIZ (José María), Antroponimia Indígena de la Lusitania Romana, Vitoria-Gasteiz, 2005.

VILLAR (Francisco), Indoeuropeos y no Indoeuropeos en la Hispania prerromana, Salamanca, 2000. 


\subsection{Estudos baseados na Epigrafia ${ }^{1}$}

\subsubsection{Sobre religião}

ALFÖLDY (Géza), "Die Mysterien von Panoias (Vila Real - Portugal)", Madrider Mitteilungen 381997 176-246 (+ 41 estampas).

BARATTA (Giulia), Il Culto di Mercurio nella Penisola Iberica, Barcelona, 2001. BLÁZQUEZ (José María), Religiones en la España Antigua. Madrid, 1991. (Com abundante bibliografia, substitui os seus anteriores trabalhos sobre este tema).

BLÁZQUEZ (José María), Religiones, Ritos y Creencias Funerarias de la Hispania Prerromana. Madrid, 2001.

BLÁZQUEZ (José María), Arte y Religión en el Mediterráneo Antiguo. Ediciones Cátedra, Madrid, 2008.

CRESPO ORTIZ DE ZÁRATE (Santos) e ALONSO ÁVILA (Ángeles), Las Manifestaciones Religiosas del Mundo Antiguo en Hispania Romana: El Território de Castilla y León - I - Fuentes Epigráficas. Valladolid, 1999.

ENCARNAÇÃO (José d'), Divindades Indigenas sob o Dominio Romano em Portugal, Lisboa, 1975.

ENCARNAÇÃO (José d'), Estudos sobre Epigrafia. Coimbra, 1998.

ENCARNAÇÃO (José d'), "Aspectos da religiosidade vernácula na Hispânia romana", in ANDREU PINTADO (Javier), CABRERO PIQUERO (Javier) e RODÀ de LLANZA (Isabel) [editores], Hispaniae - Las Provincias Hispanas en el Mundo Romano, Tarragona, 2009, p. 465-472. http://hdl.handle.net/10316/10495

ÉTIENNE (Robert), Le Culte Impérial dans la Péninsule Ibérique d'Auguste à Dioclétien. Paris, 1974 (reimp.).

GARCIA (José Manuel), Religiões Antigas de Portugal. Lisboa, 1991.

GARCÍA y BELLIDO (Antonio), Les Religions Orientales dans l'Espagne romaine. Leiden, 1967.

MORENO PABLOS ( $\mathrm{M}^{\mathrm{a}}$ José), La Religión del Ejército Romano: Hispania en los siglos I-III, Madrid, 2001.

NOGALES (Trinidad) e GONZÁLEZ (Julián)) [edit.], Culto Imperial: Política y Poder (Actas do congresso realizado no Museo Nacional de Arte Romano, Mérida, 18-19.05.2006), Roma, 2007.

OLIVARES PEDREÑO (Juan Carlos), Los Dioses de la Hispania Céltica, Madrid, 2002.

ORIA SEGURA (Mercedes), Hércules en Hispania: una Aproximación. Barcelona, 1996.

PRÓSPER (Blanca María), Lenguas y Religiones Prerromanas del Occidente de la Península Ibérica, Salamanca, 2002.

\footnotetext{
${ }^{1}$ Não é, minimamente, intenção de apresentar uma bibliografia exaustiva, tantas são as obras saídas nos últimos anos; por outro lado, sendo o monumento epigráfico uma fonte para praticamente todos os domínios, não há nenhuma obra sobre a Hispania Romana que não trate das fontes epigráficas. Indicamos, pois, somente algumas, que poderão - inclusive pela bibliografia que apresentam - servir de trampolim para outros estudos.
} 
Religión y Magia en la Antigüedad, Valencia (Universidad Internacional Menéndez Pelayo) 1999.

RIBEIRO (José Cardim) [coord.], Religiões da Lusitânia - Loquuntur Saxa, Museu Nacional de Arqueologia, Lisboa, 2002.

RODRÍGUEZ CORTÉS (Juana), Sociedad y Religión Clásica en la Bética Romana, Salamanca, 1991.

VASCONCELOS (José Leite de), Religiões da Lusitânia, Lisboa, 2 e 3, 1989 (reimp.).

\subsubsection{Sobre estruturas sociais}

ALARCÃO (Jorge de), "A organização social dos povos do Noroeste e do Norte da Península Ibérica nas épocas pré-romana e romana", Conimbriga 422003 5-115.

ANDREU PINTADO (Javier), Munificencia Pública en la Provincia Lusitania (siglos I-IV d. C.), Zaragoza, 2004.

CABALlOS RUFINO (Antonio), Los Senadores Hispanorromanos y Ia Romanización de Hispania (siglos I-III). I - Prosopografia. 2 vol., Ecija, 1990.

DEMOUGIN (Ségolène) e CABALLOS RUFINO (Antonio) [eds.], Migrare. La Formation des Élites Hispaniques, Bordéus, 2006.

GONZÁlEZ HERRERO (Marta), Los Caballeros Procedentes de la Lusitania Romana. Estudio Prosopografico, Madrid, 2006.

GONZÁleZ ROMÁN (Ed.), La Sociedad de la Bética. Contribuciones para su Estudio, Universidad de Granada, 1994.

HERNÁNDEZ GUERRA (Liborio), Indigenismo y romanización de la provincia de Valladolid, Valladolid, 2002.

HERNÁNDEZ GUERRA (Liborio), Pueblos Prerromanos y Romanización de la Provincia de Soria, Soria, 2005.

LE ROUX (Patrick), "Soldados hispanos en el ejército imperial romano", in ANDREU PINTADO (Javier), CABRERO PIQUERO (Javier) e RODÀ de LLANZA (Isabel) [editores], Hispaniae - Las Provincias Hispanas en el Mundo Romano, Tarragona, 2009, p. 283-292.

MELCHIOR GIL (Enrique), El Mecenazgo Civico en la Betica (La contribución de los evergetas a la vida municipal), Universidad de Cordoba, 1994.

NAVARRO CABALLERO (Milagros) \& DEMOUGIN (Ségolène), Élites Hispaniques, Bordéus, 2001.

OJEDA TORRES (Juan Matías), El Servicio Administrativo Imperial Ecuestre en la Hispania Romana durante el Alto Imperio. 1. Prosopografía. Sevilha, 1993.

PASTOR MUÑOZ (Mauricio), Sociedad y Epigrafía en Granada en Época Romana, Universidad de Granada, 2004.

RODRÍGUEZ NEILA (Juan F.) e NAVARRO SANTAN (Francisco J. (edits.), Elites y Promoción Social en la Hispania Romana, Pamplona, 1999.

SANTERO SANTURINO (J. M.), Asociaciones Populares en Hispania Romana. Sevilha, 1978. 
SAQUETE CHAMIZO (José C.), Las Elites Sociales de Augusta Emerita, Mérida, 1997. SERRANO DELGADO (José Miguel), Status y Promoción Social de los Libertos en Hispania Romana. Sevilha, 1988.

\subsubsection{Sobre organização politico-administrativa}

ALBERTOS (María Lourdes), "Organizaciones suprafamiliares en la Hispania antigua”. Valladolid, 1975. II, Boletín del Seminario de Estudios de Arte y Arqueología 471981 208-214.

ANDREU PINTADO (Javier), CABRERO PIQUERO (Javier) e RODÀ de LLANZA (Isabel) [editores], Hispaniae - Las Provincias Hispanas en el Mundo Romano, Tarragona, 2009.

CABAllos RUFINO (Antonio), El Nuevo Bronce de Osuna y la Política Colonizadora Romana, Sevilla, 2006.

CALBI (Alda), DONATI (Angela) e POMA (Gabriella) (eds.), L'Epigrafia del Villaggio. Faenza, 1993.

CASTILLO (Carmen) (ed.), Epigrafia Juridica Romana. Pamplona, 1989.

CURCHIN (Leonard A), The Local Magistrates of Roman Spain. Toronto, 1990.

DOMERGUE (Claude), "La mine antique d'Aljustrel (Portugal) et les tables de bronze de Vipasca", Conimbriga 221983 1-205.

GONZÁLEZ (Julián), "The Lex Irnitana: a new Flavian municipal law", The Journal of Roman Studies 761986 147-243.

GONZÁLEZ RODRÍGUEZ (María Cruz), Las Unidades Organizativas Indígenas del Area Indoeuropea de Hispania. Vitória/Gasteiz, 1986.

GONZÁLEZ (María Cruz) e SANTOS (Juan) (edit.), Las Structuras Sociales Indígenas del Norte de la Península Ibérica, Vitoria-Gasteiz, 1994.

LAZZARINI (Sergio), Lex Metallis Dicta (Studi sulla Seconda Tavola di Vipasca), Roma, 2001.

LE ROUX (Patrick), L'Armée Romaine et l'Organisation des Provinces Ibériques d'Auguste à l'Invasion de 409, Paris, 1982.

LE ROUX (Patrick), "Procurateur affranchi 'in Hispania': Saturninus et l'activité minière", Madrider Mitteilungen 261985 218-233.

LE ROUX (Patrick), "Municipe et droit latin en Hispania sous l'Empire", Revue Historique de Droit Français et Étranger 641986 325-350.

LE ROUX (Patrick), Romains d'Espagne, Paris, 1995.

LE ROUX (Patrick) et TRANOY (Alain), y, le mot et la chose - contribution au débat historiographique", Lucerna 1984 239-255.

ORS (Álvaro d'), Epigrafía Jurídica de la España romana. Madrid, 1953.

SILLIÈRES (Pierre), Les Voies de Communication de l'Hispanie Méridionale, Paris, 1990.

SILVA (Armando Coelho Ferreira da), "As tesserae bospitales do Castro da Senhora da Saúde ou Monte Murado (Pedroso, Vila Nova de Gaia) Contributo para o estudo das instituições e povoamento da Hispânia Antiga", Gaya 11983 9-26. 
SILVA (Armando Coelho Ferreira da), A Cultura Castreja no Noroeste de Portugal, Paços de Ferreira, 1986. ${ }^{2} 2007$ [sobretudo o capítulo III].

TOVAR (Antonio), Iberisch Landeskunde, Baden-Baden, 11974 (Bética) 21976 (Lusitânia), 31989 (Tarraconense).

226 TRANOY (Alain), La Galice Romaine. Paris, 1981.

WIEGELS (Rainer), Die Tribusinschriften des Romischen Hispanien - Ein Katalog. Berlim, 1985.

\subsection{Algumas notas à bibliografia}

\subsubsection{As grandes colecções}

\subsubsection{O CIL II}

Instrumento de trabalho imprescindivel para quantos quiserem publicar alguma coisa sobre a Epigrafia Latina da Península Ibérica, o CIL II, apesar da sua aparente facilidade de consulta, é um mundo complexo. Organizado por ordem geográfica, tem, para além do suplemento, diversas adendas, cuja localização será facilitada pela consulta do índice geral inserido no começo do suplemento. Complementares do CIL II são os Additamenta, publicados nas Ephemeris Epigraphica, os primeiros da responsabilidade do próprio Hübner, os segundos por ele compilados, mas dados à estampa, após o seu falecimento, por Dessau.

Apesar de já se encontrar revista grande parte das inscrições aí contidas, a referência ao CIL II tem sempre de fazer-se. Até porque sempre se impõe uma leitura atenta do que Hübner escreveu: há as referências bibliográficas, há a bibliografia comentada, há as dúvidas, os textos que o investigador viu (descripsi, como ele menciona), há os de que apenas teve conhecimento indirecto, há as hipóteses de interpretação. Enfim, um instrumento a utilizar convenientemente e com astúcia. Para isso temos os índices, riquíssimo manancial de informações, como facilmente se aperceberá quem folhear calmamente as p. 1191-1205.

Importa não esquecer também que existem três numerações das páginas: a numeração árabe respeita ao texto propriamente dito; a numeração árabe com asterisco refere-se às páginas das inscrições falsas; a numeração romana indica as páginas de introdução. E o suplemento continua a numeração do $1^{\circ}$ volume. As inscrições são numeradas e a citação faz-se sempre por esse número; assim, CIL II 5002 é a inscrição no 5002 . Neste caso, a página nunca se cita. Se pelo número for difícil encontrar a inscrição, vai-se ao índice (início do $2^{\underline{o}}$ volume): aí se indicam as grandes divisões geográficas, as páginas e os números das inscrições a elas respeitantes.

Evidentemente, se uma inscrição não aparece no CIL II, não se pode dizer, sem mais, que está inédita. Generalizações - de qualquer ordem que sejam quando tomarem como único ponto de partida o CIL II, devem ser cautelosas e mencionar sempre que apenas se baseiam no CIL II. Fazem-se afirmações absurdas por não se ter em conta este factor. Por outro lado, uma leitura apressada 
do CIL II pode induzir em erros graves: a consulta atenta dos índices impõe-se em todos os casos. Por exemplo, surge-nos numa epígrafe a fórmula DIS MANIBVS por extenso; para sabermos da sua ocorrência na Península basta abrir o CIL II na pág. 1174; se pretendermos conhecer quais os qualificativos mais comuns dados aos maridos, temos os exemplos na pág. 1198, exactamente na palavra mariti (fim da $1^{\underline{\underline{a}}}$ coluna). E assim por diante.

Há, ainda, um índice geográfico, com as coordenadas para localização nos mapas do final do $2^{\circ}$ volume.

O CIL faz parte de um empreendimento notável a cargo da Academia de Berlim desde meados do século passado, o qual visa abarcar toda a epigrafia do mundo romano, obedecendo a um critério geográfico e temático de distribuição. Procede-se em todos os países do antigo Império Romano à actualização do CIL que lhes diz respeito e já atrás se indicaram os novos volumes relativos à Península Ibérica, publicados no âmbito dessa actualização.

Porque o estudioso da Epigrafia verá a cada passo referências a este ou aquele volume, aqui fica uma panorâmica desta colecção:

I - República; II - Península Ibérica; III - Ásia; IV - Pompeios, Herculano e Estábias; V - Gália Cisalpina; VI - Roma; VII - Bretanha; VIII - África; IX - Itália (sensivelmente as regiões do Norte); X - Itália (Sul); XI - Itália (Centro); XII Gália Narbonense; XIII - Três Gálias e Germânia; XIV - Lácio; XV - Ânforas e lucernas de Roma (instrumentum domesticum); XVI - Documentos militares; XVII - Miliários.

Acessível em: http://cil.bbaw.de/

\subsubsection{Outras colecções peninsulares}

Citamos, na bibliografia, outras colecções peninsulares, como a Hispania Antiqua Epigraphica (HAE) e a obra de J. Vives (ILER). L'Année Épigraphique (AE) traz igualmente inscrições da Península, em capítulo próprio. Dessau, nas suas Inscriptiones Latinae Selectae (ILS), também incluiu algumas.

Todas estas colecções se devem referenciar, se possível. A consulta dos seus índices revela-se sempre muito útil. No entanto, convém sempre que possível testar as referências.

HAE teve, de certo modo, continuidade na também citada Hispania Epigraphica, primeiro repositório do trabalho de revisão do CIL II que está a ser efectuado, com vista à já referida nova edição deste corpus. Depois de um período de alguma irregularidade de publicação, constitui hoje um elemento de referência primordial (14ํำ volume em 2008); já se encontra acessível através de http://www.ucm.es/info/archiepi/aevh/index2.html

Quanto ao ILER, como já o dissemos (Conimbriga XV 1976 179-182), para além das gralhas tipográficas, existem duplicações e omissões. Não foi intenção de Vives fazer um catálogo exaustivo da epigrafia peninsular, que ordenou por grandes temas. Por isso, o facto de um antropónimo não vir registado nos índices do ILER não é motivo suficiente para que se diga que não está documen- 
tado na Península. Uma consulta à obra de Abascal e, no caso da Lusitânia, ao Atlas Antroponímico é imprescindível.

Pela metodologia utilizada, sugerimos uma leitura atenta do volume dedicado à epigrafia de Conímbriga: Fouilles de Conimbriga II.

\subsubsection{Bibliografias}

O Institut Ausonius (ex-Centre Pierre Paris), da Universidade de Bordéus III, inclui nas suas crónicas de História e de Arqueologia da Península Ibérica Antiga uma secção de Epigrafia, onde se enumeram e comentam os livros e artigos publicados. Veja-se, pois: ÉTIENNE (R.) e MAYET (F.) (eds.), Histoire et Archéologie de la Péninsule Ibérique (Vingt ans de recherches 1968-1987), Paris, 1993.

Carmen Castillo tem procurado fazer, por ocasião dos congressos internacionais de Epigrafia, um balanço que intitula «El progreso de la epigrafía romana de Hispânia": para 1967-1972, Emerita 411973 109-127; para 1972-1977, ibidem, 471979 35-66; para 1977-1982, ibidem, 531985 205-248; para 1983-1987, ibidem, 591991 225-273; para 1988-1992, ibidem, 631995 187-223.

Alicia Canto publicou "Un veintenio clave para la Epigrafía Latina de España", Boletín de la Asociación Española de Amigos de Arqueologia, 30-31, 1991, $247-$ 270 (cf. AE 1991 926), onde refere as publicações feitas entre 1771 e 1991.

Interessará consultar Épigraphie Hispanique - Problèmes de Méthode et d'Édition, Paris, 1984 (Actas da mesa-redonda internacional realizada em Bordéus, Dezembro de 1981) assim como, de Eduardo Pires Oliveira, Bibliografia Arqueológica Portuguesa (1935-1969), Lisboa, 1984, Bibliografia Arqueológica Portuguesa (1970-1979), Lisboa, 1985, e Bibliografia Arqueológica Portuguesa (séc. XVI-1934), Lisboa, 1993. Para a actividade recente dos epigrafistas portugueses: Repertório Bibliográfico da Historiografia portuguesa (1974-1994), Coimbra, 1995.

A revista Hispania Antiqua publicou também dois suplementos bibliográficos. Num âmbito mais geral, L'Année Philologique apresenta um resumo de praticamente todos os artigos publicados no mundo inteiro sobre epigrafia, em cada ano. O trabalho de M. Clauss - "Ausgewählte Bibliographie zur lateinischen Epigraphik der römischen Kaiserzeit (1.-3. Jh.)", Aufstieg und Niedergang der Römischen Welt 211974 798-855 - ainda se mantém pleno de utilidade. Joyce Reynolds, M. Beard e Charlotte Roueché costumam publicar no Journal of the Roman Studies balanços quinquenais da actividade epigráfica: por exemplo, no no 761988 124-146: 1981-1985; no 871997 203-240: 1991-1995; no 93 2003, p. 212-294: 1995-2000.

Ver também: BÉRARD (François) et alii, Guide de l'Épigraphiste (Bibliographie Choisie des Épigraphies Antiques et Médiévales). Presses de l'École Normale Supérieure, Paris, 32000. Ver em http://www.antiquite.ens.fr/txt/ dsa-publications-guidepigraphiste-fr.htm as sucessivas actualizações, passíveis de ser descarregadas; o 9ำ suplemento refere-se a 2008-2009 e o $10^{\circ}$ está previsto para Junho de 2010. 
Para publicações mais antigas, cf.: MAULEON (María Dolores), Indices de las Inscripciones Latinas Publicadas en el Boletín de la Real Academia de la Historia (1877-1950), Pamplona, 1983; e GIMENO PASCUAL (Helena), Historia de la Investigación Epigráfica en España en los ss. XVI y XVII, Saragoça, 1997.

Assinale-se que os investigadores ligados à Real Academia de la Historia estão a publicar os fundos bibliográficos, designadamente manuscritos, daquela instituição, o que constitui fonte importante de informações - cf. o número especial, de 2009, da revista Ibn Maruan, de Marvão. Veja-se, por exemplo: ABASCAL (Juan Manuel) e CEBRIÁN (Rosário), Los Viajes de José Cornide por España y Portugal de 1754 a 1801, Madrid, Real Academia de la Historia, 2009.

\subsubsection{A antroponímia}

A análise antroponímica constitui parte relevante do comentário histórico de um texto, até porque dela se podem tirar ilações demográficas de vulto.

E se uma atenção especial se deve dar aos gentilícios, a fim de se detectarem relações familiares (mormente quando os praenomina são iguais), os cognomes podem, pela sua etimologia, apontar interessantes pistas de investigação.

No concernente à onomástica de etimologia grega, o livro mais completo é o de Solin (1982), embora em Epigraphica $59199729-96$ já se tenha uma panorâmica da epigrafia grega peninsular. Cf., a este propósito, as observações de Robert Étienne (in L'Onomastique Latine 1977 291-292).

Obra importante é a citada de Kajanto: os índices constituem uma lista bastante completa dos cognomes latinos registados epigraficamente em todo o mundo romano, o que representa, sem dúvida, um excelente instrumento de trabalho - mesmo sem termos em conta toda a análise que o autor faz de cada grupo de cognomes.

Quem se dedique ao estudo da onomástica indígena - também chamada "celta" ou "de raiz pré-latina" - deverá consultar os trabalhos de M. L. Albertos, as actas dos colóquios sobre línguas e culturas paleo-hispânicas e a revista Palaeohispanica. O Atlas de J. Untermann já está desactualizado, porque muitos outros testemunhos se descobriram após a sua publicação: serve, no entanto, como importante amostra tendencial. O citado Atlas Antroponímico de la Lusitania Romana, o livro de José María Vallejo e a obra de Juan Manuel Abascal são, actualmente, nesse domínio, obras de consulta imprescindível, como se disse.

\subsubsection{A religião}

As inscrições votivas requerem um comentário sobre a religião na Península Ibérica. As Religiões da Lusitânia, de José Leite de Vasconcelos, continuam a ser a fonte clássica e inesgotável de dados a tal respeito. O volume Religiões Antigas de Portugal - Fontes epigráficas, de José Manuel Garcia, constitui oportuna actualização do muito que, sobre este assunto, se tem publicado ultimamente. 
No âmbito das divindades indígenas, as obras de José María Blázquez vão sendo constantes actualizações do que escrevera em anteriores trabalhos; e os textos incluídos no catálogo da exposição Religiões da Lusitânia actualizam também, eloquentemente, toda essa problemática.

\section{NOÇÕES ELEMENTARES DE LATIM}

Em Latim, a função sintáctica dos nomes é indicada pelos casos:

\begin{tabular}{|c|c|}
\hline sujeito & nominative \\
\hline $\mathrm{Compl}^{\circ}$ directo & acusativo \\
\hline Compl $^{\circ}$ determ ${ }^{\circ}$ & genitivo \\
\hline Compl indir ${ }^{\circ}$ & dativo \\
\hline c. circunst. & ablativo \\
\hline vocativo & vocativo \\
\hline
\end{tabular}

Os casos distinguem-se pelas desinências (terminações), variáveis segundo as declinações. Para a Epigrafia, interessam sobretudo as três primeiras declinações:

$1^{\underline{a}}$ nomes, geralmente femininos, terminados em $\mathbf{a}$ : amica, Marina, Iulia, pientissima

$2^{\underline{a}}$ a) nomes, geralmente masculinos, terminados em us:

deus, Iulius, maritus, amicus, Augustus

b) nomes, neutros, terminados em um: aedificium, aerarium, votum

c) $\operatorname{vir}($ homem), puer (rapaz)

$3^{3}$ nomes - masculinos, femininos e neutros - terminados em consoante ou em o: pater, coniux, imperator, Caesar, Cato (gen. Catonis), nepos (gen. nepotis), consul.

As desinências vão indicadas a seguir:
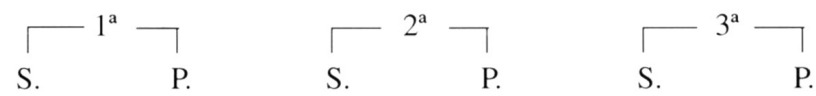

\begin{tabular}{|c|c|c|c|c|c|c|}
\hline nom. & amica & amicae & amicus & amici & Caesar & Caesares \\
\hline acus. & amicam & amicas & amicum & amicos & Caesarem & Caesares \\
\hline gen. & amicae & amicarum & amici & amicorum & Caesaris & Caesarum \\
\hline dat. & amicae & amicis & amico & amicis & Caesari & Caesaribus \\
\hline abl. & amica & amicis & amico & amicis & Caesare & Caesaribus \\
\hline
\end{tabular}


CARDINAIS

unus, a, um

duo, duae, duo

tres, tres, tria

quattuor

quinque

sex

septem

octo

novem

decem

undecim

duodecim

tredecim

quattuordecim

quindecim

sedecim

septendecim

duodeviginti

undeviginti

viginti

unus et viginti

duodetriginta

undetriginta

30 triginta

40 quadraginta

50 quinquaginta

60 sexaginta

70 septuaginta

80 octoginta

90 nonaginta

100 centum

200 ducenti

$300 \quad$ trecenti

$400 \quad$ quadringenti

500 quingenti

600 sescenti

700 septingenti

$800 \quad$ octingenti

900 nongenti

1000 mille, milia

2000 duo milia

\section{Declinações}

nom. unus, a, um

acus. unum, am, um

gen. unius

dat. uni

abl. uno, una, uno
NUMERAIS

ORDINAIS

primus, a, um

secundus

tertius

quartus

quintus

sextus

septimus

octavus

nonus

decimus

undecimus

duodecimus

tertius decimus

quartus decimus

quintus decimus

sextus decimus

septimus declmus

duodevicesimus

undevicesimus

vicesimus

unus et vicesimus

duodetricesimus

undetricesimus

tricesimus

quadragesimus

quinquagesimus

sexagesimus

septuagesimus

octogesimus

nonagesimus

centesimus

ducentesimus

trecentesimus

quadringentesimus

quingentesimus

sescentesimus

septingentesimus

octingentesimus

nongentesimus

millesimus

bis millesimus formam-se a partir do

ordinal terminando em um 
Série

Ensino

Imprensa da Universidade de Coimbra

Coimbra University Press

2010

- U o d C 